\title{
De ontdekking van het prothrombine
}

Citation for published version (APA):

Hemker, C. W. (1981). De ontdekking van het prothrombine. [Doctoral Thesis, Maastricht University]. Ronald Meesters. https://doi.org/10.26481/dis.19811204ch

Document status and date:

Published: 01/01/1981

DOI:

10.26481/dis.19811204ch

Document Version:

Publisher's PDF, also known as Version of record

\section{Please check the document version of this publication:}

- A submitted manuscript is the version of the article upon submission and before peer-review. There can be important differences between the submitted version and the official published version of record.

People interested in the research are advised to contact the author for the final version of the publication, or visit the DOI to the publisher's website.

- The final author version and the galley proof are versions of the publication after peer review.

- The final published version features the final layout of the paper including the volume, issue and page numbers.

Link to publication

\footnotetext{
General rights rights.

- You may freely distribute the URL identifying the publication in the public portal. please follow below link for the End User Agreement:

www.umlib.nl/taverne-license

Take down policy

If you believe that this document breaches copyright please contact us at:

repository@maastrichtuniversity.nl

providing details and we will investigate your claim.
}

Copyright and moral rights for the publications made accessible in the public portal are retained by the authors and/or other copyright owners and it is a condition of accessing publications that users recognise and abide by the legal requirements associated with these

- Users may download and print one copy of any publication from the public portal for the purpose of private study or research.

- You may not further distribute the material or use it for any profit-making activity or commercial gain

If the publication is distributed under the terms of Article $25 \mathrm{fa}$ of the Dutch Copyright Act, indicated by the "Taverne" license above, 
DE ONTDEKKING VAN HET PROTHROMBINE 


\section{DE \\ ONTDEKKING VAN HET \\ P R O T H R O M B I N E}

PROEFSCHIFT

TER VERKRIJGING VAN DE GRAAD VAN

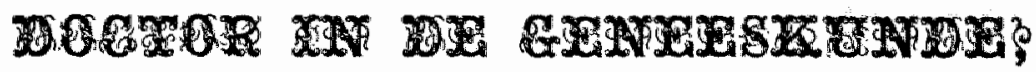

AAN DE RIJKSUNIVERSITEIT LIMBURG TE MAASTRICHT

OP GEZAG VAN DE RECTOR MAGNIFICUS

PROF. DR. W.H.F.W. WIJNEN,

VOLGENS BESLUIT VAN HET COLLEGE VAN DEKANEN

IN HET OPENBAAR TE VERDEDIGEN

IN DE AULA VAN DE UNIVERSITEIT

OP VRIJDAG 4 DECEMBER 1981

DES NAMIDDAGS TE 16.00 UUR

door

CHRISTIAAN WILHELM HEMKER

geboren te Amsterdam 
Promotor: Prof.Dr. H.C. Hemker

Referenten: Prof.Dr. E.A. Loeliger

Prof.Dr. R.S. Reneman 
Haud facile emergunt, quorum virtutibus obstat Res augusta domi.

Juvenalis, Satirae 3, 163.

Dit proefschrift is opgedragen aan de nagedachtenis van Klazina Johanna Hemker-Nanninga, de moeder van mijn kinderen. 


\section{INHOUD}

Voorwoord $\ldots \ldots \ldots \ldots \ldots \ldots \ldots \ldots \ldots \ldots \ldots \ldots \ldots \ldots \ldots$

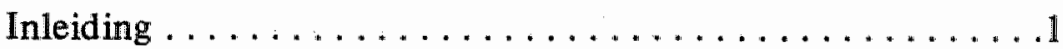

Hoofdstuk I Vroege opvattingen over de bloestolling . . . . . . 7

a. Physische en Vitalistische verklaringen . . . . . . . . 7

b. Cellen of plasma ?.................... 14

c. Fibrine of Fibrinogeen?................21

Hoofdstuk II A.Buchanan en zijn werk . . . . . . . . 23

a. Het herhalen van historische experimenten . . . . . 23

b. Andrew Buchanan's werk . . . . . . . . . . . . .26

c. Wat heeft Buchanan waargenomen? ...........32

Hoofdstuk III Alexander Schmidt en zijn opponenten ......37

a. Levensbeschrijving. .................. 37

b. Schmidt's inzichten over de bloedstolling . . . . . . . 44

c. De opponenten van Alexander Schmidt . . . . . . . 49

Hoofdstuk IV De rol van het Cat+ en de verdere ontwikkeling van het bloedstollingsonderzoek............55

a. Arthus en Pagès. ...................... 55

b. De ontwikkelingen na Schmidt . . . . . . . . . .64

Hoofdstuk V Pekelharing èn het prothrombine . . . . . . . .69

a. De persoon Pekelharing. .................69 
b. De ontdekking van het Prothrombine ..........74

c. De plaats van Pekelharings ontdekking in zijn tijd. . . 82

d. Wat heeft Pekelharing waargenomen? . . . . . . . 88

e. Hoe stelde Pekelharing zich het prothrombine voor . .90 Hoofdstuk VI Levensschets van C.A. Pekelharing . . . . . . .93

a. Jeugd te Zaandam ..................93

b. Studietijd ........................ 100

c. Eerste praktijkharen en arts te Leiden $1872-1878$. . 104

d. De jaren aan de Rijks-Veeartsenijschool te Utrecht $1878-1881 \ldots \ldots \ldots \ldots \ldots \ldots \ldots \ldots \ldots \ldots \ldots$

e. Hoogleraar aan de Med.Fac. der Rijks Universiteit te Utrecht 1881-1918 ................110

f. Pekelharing en de beri-beri .................113

g. De jaren in het Physiologisch Laboratorium 1888-

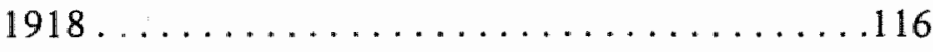

h. Pekelharing, de med. opleiding en de Mij. der Geneeskunde........................ 121

i. Omstreeks de eeuwwisseling en later. . . . . . . 125 Appendix A: De huidige opvattingen over de thrombinevorming. . . . . . . . . . . . . . . . 133

Appendix B: Bibliografie a. Facsimile proefschrift Schroeder v.d. Kolk ........147

b. Pekelharing . . . . . . . . 197

c: Algemene literatuurlijst ....208

Summary and conclusion ...................229

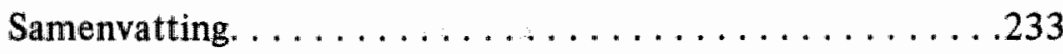

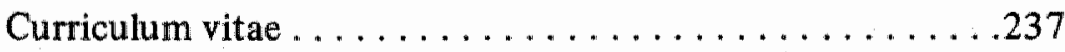

viii 


\section{VOORWOORD}

Het voor $U$ liggende proefschrift geeft mij een gelegenheid te meer, dank te brengen aan de hoogleraren en lectoren, die in de vijftiger jaren mijn leermeesters zijn geweest aan de Gemeente Universiteit van Amsterdam, toen ik als lid van de technische staf eerst officieus bij hun colleges, colloquia en informele gesprekken aanwezig mocht zijn en later na het begin van mijn studies in de biologie ook officieel.

Helaas zijn enkele van de meest markante figuren ons reeds ontvallen. Met dankbaarheid en bewondering denk ik terug aan de hoogleraren ten Cate, van Herk en Slijper.

Wat ik in mijn jaren aan het fysiologisch laboratorium aan de Universiteit van Amsterdam als het ware door diffusie van de wetenschappelijke staf heb opgestoken zal nooit te becijferen zijn. Ik wil hier in het bijzonder met dank noemen de hoogleraren Bernards, Biersteker, Boeles, Bouman, Horsten, Meyler, Punt, Visser en de Wilde.

Voor mijn doctoraalexamen kwam ik weer in een heel andere omgeving: het Biologisch Laboratorium van de Vrije Universiteit te Amsterdam. Hier noem ik met grote erkentelijkheid de hoogleraren Lever, Joosse en de Vlieger en de doctores Biewenga, Goldschmeding, Janse, Lever, Stoll, ter Maat en van Swighem.

Beste Coen, hooggeachte promotor, dierbare zoon, hoe lang is het alweer geleden dat je mij toen je semi-arts was, aanraadde te gaan studeren. Onze gemeenschappelijke belangstelling lag al heel vroeg op het gebied van de fysiologie, de histologie en de biochemie, waarin ik eerst jou en jij later mij, tot gids 
diende. Het was dan ook jouw terrein, de studie van de bloedstolling, waaruit ik het onderwerp wan mijn proefschrift heb gekozen. Daarbij zocht ik het niet in het actieve grensverleggende onderzoek, met zijn fascinerende maar hectische sfeer, maar in het meer beschouwelijke, meer bij mijn leeftijd passende, evalueren van oude onderzoekingen. In het bijzonder is het de grote Pekelharing geworden, die ons na veel jaren op één vakgebied samenbracht, nu in de relatie promotor-promovendus. Ik ben je zeer erkentelijk voor de grote vrijheid die je mij bij het schrijven van deze dissertatie gelaten hebt en ook voor de waardevolle aanwijzingen die geleid hebben tot selectie. aanvulling en verbetering van het oorspronkelijke manuscript. Nooit zal ik de drukke doch gezellige tijd dat ik in het Bio medisch Centrum van de Rijksuniversiteit Limburg te Maastricht en bij jou thuis mocht werken, vergeten.

Prof. Dr. E.A. Loeliger en Prof. Dr. R.S. Reneman dank ik yoor hun bereidheid als referent op te treden en voor het kritisch lezen van het manuscript.

Zeer geachte vriend Devilee, beste Paul, ik dank je bijzonder voor de begeleiding bij het begin van mijn stolexperimenten en voor de instructie bij het gebruik van de computer.

De secretaressen Hélène Vermeer, Mariet Molenaar en de dames van de bibliotheek, dank ik hartelijk voor alle hulp die zij mij gegeven hebben.

Tenslotte dank ik de gehele staf van het biochemisch laboratorium van het Biomedisch Centrum te Maastricht voor de hulp en toewijding die ik bij mijn niet eigentijdse vragen en proeven van hen mocht ondervinden.

Terugziende op mijn loopbaan, eerst als technicus bij de P.T.T. en het Fysiologisch Laboratorium en daarna als docent aan het Spinoza Lyceum, komen mij talrijke vrienden in gedachten met wie ik op bijzonder prettige wijze heb samengewerkt. Mijn loopbaan als docent is meestentijds zeer aangenaam geweest en ik denk met waardering aan vooral de oudere collegae, 
van wie ik zonder de anderen te kort te willen doen de namen noem van Richard en Martha Bierman, Piet van Biezen en Gerben Rijpma.

Het aantal van diegenen op wier hulp ik een beroep gedaan heb bij het verzamelen van historische gegevens in archieven en bibliotheken is groter dan ik bij het ondernemen van deze studie kon vermoeden.

Van hen wil ik noemen Mme Hilda Benichou, Conservateur du Musée Pasteur te Parijs en Drs. Marinus van Hattem, bibliothecaris van de bibliotheek van het Nederlands Tijdschrift voor Geneeskunde te Amsterdam. 



\section{INLEIDING}

Over de grote verdiensten van Arthus en Pagès, Buchanan, Hammersten, Schmidt en Virchow voor de ontwikkeling van de kennis over de bloedstolling, is reeds veel geschreven en nageschreven, zoveel, dat toevoeging van een nieuw opstel aan de reeds bestaande misschien wel niet gerechtvaardigd zou zijn. Het is denkbaar dat men zijn tijd nuttiger kan besteden dan met het herhalen van een goed gedane opgraving.

Het is mogelijk dat door een nieuw type zeef nog eens een scherfje of zelfs een scherf wordt tegengehouden en ze blijken zelfs tot vreugde van de onderzoeker, zeer wel te passen in hetgeen reeds ontdekt is. De kans is echter groter dat het moeizame ziften niets nieuws meer oplevert, zodat men op zijn beurt slechts een nieuwe beschrijving kan geven van het reeds door anderen geconstrueerde en onder een bepaalde visie en belich- 
ting, voorgestelde kunstvoorwerp.

Met betrekking tot belangrijke studies zoals die van Arthus en Pagès en die van Buchanan waarvan bekend is dat zij het materiaal hebben geleverd dat aan ons begrip van de bloedstolling ten grondslag ligt, zou het niettemin reeds een nuttige bezigheid kunnen zijn. De van bovengenoemde auteurs bekende publicaties geven de lezer meer dan hij bevroedt en trekken minder lezers dan zij verdienen. Door bijzondere omstandigheden over ruim voldoende tijd beschikkende, heb ik het beeld, dat zeer zeker niet als een nieuwe vondst beschouwd moet worden, heel voorzichtig verplaatst om ook de tot op heden minder fel belichte delen aan een nadere beschouwing te kunnen onderwerpen. Een prettige verrassing was het toen daarbij bleek dat een wezenlijk deel van ons totaalbeeld van de bloedstolling te danken is aan het werk van een Nederlands onderzoeker. Zeker, het was al bekend dat Pekelharing belangrijk onderzoek had gedaan over het prothrombine. Toch wordt uit vele moderne overzichtsartikelen niet duidelijk wat zijn bijdrage eigenlijk was.

Het bronnenonderzoek maakt onomstotelijk duidelijk dat het Pekelharing was die als eerste onderkende, dat het bloedplasma zelf, het proenzym bevat, waaruit het "stollingsferment" thrombine onstaat. Zodat hij met recht als de ontdekker van het prothrombine beschouwd mag worden.

Pekelharing leefde van 1848-1922. Hij was van 21 september 1881 tot 14 juni 1918 hoogleraar aan het physiologisch Laboratorium van de Utrechtse Hogeschool. Zijn opleiding en actieve wetenschappelijke leven omvat dus het tijdperk waarin o.a. Pasteur te Parijs, Koch te Berlijn, Donders in Utrecht, Hammersten in Upssala, Virchow in Berlijn werkten. Dit, toch niet zo verre verleden, waarin de grondslagen van de moderne geneeskunde werden gelegd, ademt een heel aparte sfeer van wetenschappelijk optimisme en enthousiasme, die de moderne lezer die zich daarin verdiept direct opvalt.

Wie zich een beeld wil vormen van de geest waarin de wetenschap der geneeskunde en de daarbij behorende biologische problemen in die tijd werden benadert, leze de rede van Fran- 
ciscus Cornelis Donders, waarmede hij, in de Franse taal, het Internationale Congres van Geneeskundigen te Amsterdam op 7 semptember 1879 opende.

Hierin zegt hij o.a.: Aux sciences physiques, avec lesquelles le lien n'avait jamais été rompu, le médecin empruntait la méthode exacte qui leur est propre ainsi que les multiples moyens d'investigation et guidé par la physiologie il s'efforçait de pénêtrer, d'une part, jusques aux causes efficientes, de l'autre, jusqu'a la signification et aux rapports des symptômes.

En ook: M.M., si, en general, la science ne rend qu'indirectement service à notre art, elle réussit quelquefois $\dot{a}$ lui offrir de nouveaux horizons, ou mème à lui dicter des vérités, sur lesquelles l'art n'a plus qu'a poser son sceau.

Dan: Përiode merveilleuse; où tant de faits surprenants sont mis au jour et ouvrent des points de vue qui invitent, excitent, entrainent à des recherches nouvelles! S'étonnera-ton que les laboratoires florissent, ou gràce à une technique parfaite, les questions les plus délicates sont résolues avec une extrème précision et où quelquefois des recherches heureusement cenduites répandent une soudaine clarté sur de grands problèmes? Verder: Mais, dans la libre expression de nos pensées, évitons un écueil. Gardon-nous d'imposer nos convictions à autrui. Ici s'applique l'adage: Hanc veniam petimusque damusque vicissim. *

Rappelons-nous que la vérité ne triomphe que par la valeur de l'argumentation et non par des affirmations impérieuses. Later: Que chacun jette son ferment dans cette mer vaste et bouillonnante où des milliers de pensées se heurtent, s'entre croisent; la vérité épurée de plus en plus, finira par surnager. Tenslotte: En science comme en politique; les conservateurs d'aujourd"hui sont les liberaux d'hier. Mais progressistes, ils le sont tous.

De vooruitgang van de geneeskundige kennis in de vijftig jaren rondom de laatste eeuwwisseling was enorm. Het is niet overdreven te stellen dat op de grondslagen die toen werden gelegd,

*Dit recht eisen wij zelf en staan wij op onze beurt toe. Horatius, Ars poetica 11 . 
het gehele gebouw van de moderne geneeskunde is opgetrokken. Het kost moeite de verleiding te weerstaan om dit met vele voorbeelden te adstrueren. De weerklank die de grote namen die ik aan het begin van dit hoofdstuk noemde nu nog bij de medicus vinden zij een voorlopig bewijs.

Om snel ter zake te komen: ook het onderzoek wan de bloedstolling kreeg in die tijd de basis waarop moderne inzichten berusten.

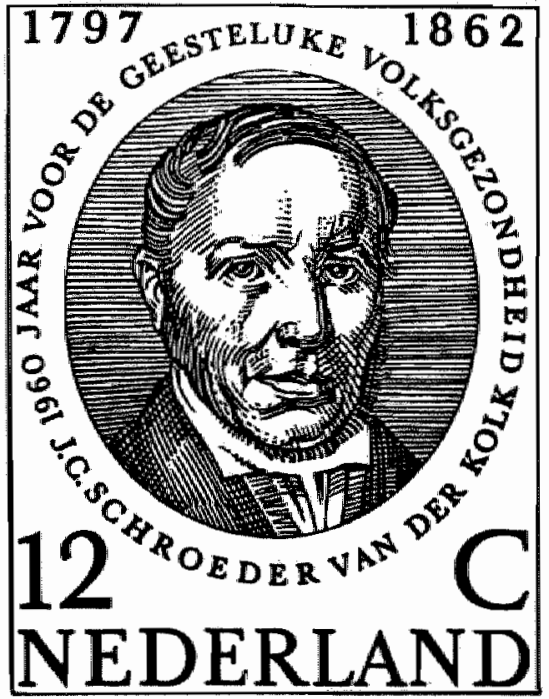

Afb. 1: J.C. Schroeder van der Kolk. Ontwerp voor de postzegelserie " 1960 jaar voor de geestelijke volksgezondheid" (Postmuseum Den Haag). 
Als Schröder van der Kolk in 1820 zijn dissertatie, "Dissertati physiologico-medica inauguralis, sistens sanguinis coagulantis historiam, cum experimentis ad eam illustandam institutis" aan de faculteit te Groningen aanbiedt vatte hij daarin, de op dat moment heersende visie op de bloedstolling samen, zoals hij die heeft bijeengelezen uit een vierhonderdtal oudere artikelen en komt tot een radicaal verkeerde conclusie.

In 1920 is echter het meest essentiele van het mechanisme van de bloedstolling bekend. Het is dan duidelijk dat het een enzymatisch proces is dat in gang wordt gezet door proenzym - enzym overgangen. Hoe buitengewoon ingewikkeld het proces is vermoedt men weliswaar nog niet, want pas in de laatste decennia heeft men een min of meer compleet beeld kunnen krijgen van het totale mechanisme; maar er is een gezonde grondslag voor verder onderzoek.

Om een globaal overzicht te krijgen van de ontwikkeling van het inzicht in de bloedstolling, is het soms noodzakelijk, in de tijd verder terug te gaan dan het begin der tweede helft van de negentiende eeuw, o.a. omdat uit de auteurs van die tijd - op overigens nogal onregelmatige wijze - geciteerd wordt.

Bij het lezen van publicaties uit de negentiende eeuw valt het toch op, dat toen bij de verschillende auteurs een overzicht, over de tot dan verschenen artikelen ontbreekt. Dat verwarring en controverse heersen. Pas in 1905 als O. Morawitz zijn beroemd geworden overzichtsartikel schrijft in "Ergebnisse der Physiologie" Bd. 4. pag. 307-422 met als titel "Die Chemie der Blutgerinnung" krijgt men de indruk dat er iemand aan het woord is die het hele gebied en ook de oudere literatuur erover beheerst en op een bezonken wijze bespreekt. 


\section{VROEGE OPVATTING OVER DE BLOEDSTOLLING}

\section{1a Natuurkundige en Vitalistische verklaringen}

Tot de eerste helft van de negentiendle eeuw bestaan er twee opvattingen over de bloedstolling.

De eerste trachtte het verschijnsel natuurkundig te verklaren, de tweede roept het "vitaal principe" te hulp en stelt dat "levend" bloed vloeibaar is en "dood" bloed gestold. Soms ontmoet men deze theorie in meer bedekte vorm, waar de auteurs stellen dat alleen stromend bloed "levend" bloed is. De natuurkundige opvatting verklaarde de bloedstolling naar analogie van het bevriezen van water. Wanneer het bloed buiten het lichaam komt, gaat het door fysische milieuverandering in vaste toestand over. Zoals boven reeds opgemerkt, bij het lezen van publicaties uit de negentiende eeuw valt het steeds weer op hoe slecht de verschillende onderzoekers van elkaars werk op de hoogte zijn. Hoe iedere onderzoeker weer probeert alle problemen van de bloedstolling zelf op te lossen, zonder zich te verdiepen in wat voor hem wordt gedaan. Gedeeltelijk moet men dit waarschijnlijk wijten aan een gebrek aan adaequate informatie systemen. Ik heb niet kunnen vaststellen dat men b.v. in Dorpat in 1875 beschikte over b.v. de London Medical Gazette van 1845, hoewell het, zoals straks zal blijken voor Alexander Schmidt essentieel moet zijn geweest het werk van Buchanan te kennen.

Het is zelfs onduidelijk of men er op enigerlei wijze achter kan 
komen waar en hoe er iets op het gebied van de bloedstolling werd gepubliceerd, behalve dan door direct persoonlijk contact. Zulk contact op congressen en vergaderingen, in vriendelijke briefwisseling of felle polemiek kan uiteraard nooit het systematisch karakter hebben gehad, dat wij nu in de wetenschappelijke informatieverwerking zo essentieel vinden. Dit vooral ook omdat het onderzoek van de bloedstolling tot ver in de twintigste eeuw een hobby is gebleven van enkele, vrij geisoleerde geleerden of een nevenactiviteit van onderzoekers, die op ander gebied meer bekend waren. Misschien is er nog een tweede reden. ledere keer valt het weer op hoe fel de toon is die de heren onderzoekers tegen elkaar aanslaan. Men kan zich niet aan de indruk onttrekken dat in de vorige eeuw de rivaliteit in de medische wetenschap openlijker naar voren kwam dan nu gebruikelijk is en dat men misschien niet zo geinteresseerd was in wat men zelf niet had gevonden. Een en ander maakt dat het lastig is, het net van wederzijdse beinvloedingen te ontrafelen, te zien wie welk fenomeen voor het eerst juist heeft waargenomen en correct geinterpreteerd, wie daarvan nog meer op de hoogte was, etc. Een strikt chronologische volgorde zegt weinig. Er zal althans om enig overzicht te houden geregeld van afgeweken moeten worden.

Maar laten wij terugkeren tot de natuurkundige opvatting. Voor zover ik heb kunnen nagaan is Aristoteles, 322 v.C. (1952) de eerste auteur van deze gedachte, hij verklaarde de bloedstolling door aan te nemen, dat het bloed in het lichaam door het hart op een bepaalde temperatuur gehouden wordt, waardoor het vloeibaar blijft. Buiten het lichaam stolt het door afkoeling, waarbij een dradenvormende stof wordt afgescheiden. Deze "koudetheorie" bleef eeuwenlang in zwang en zelfs Marcello Malpighi (1682) die het bloed afkoelde en zag dat dit de stolling bleek te vertragen, waardoor hij de vorming van een fibrinekorst beter kon waarmemen, heeft niet aan Aristoteles' autoriteit durven tornen. Tot lang na de ontdekking van de bloedstroom door William Harvey in 1651, waren alle pogingen om de bloedstolling te verklaren zuiver speculatief. De eerste poging tot een wetenschappelijke verklaring 


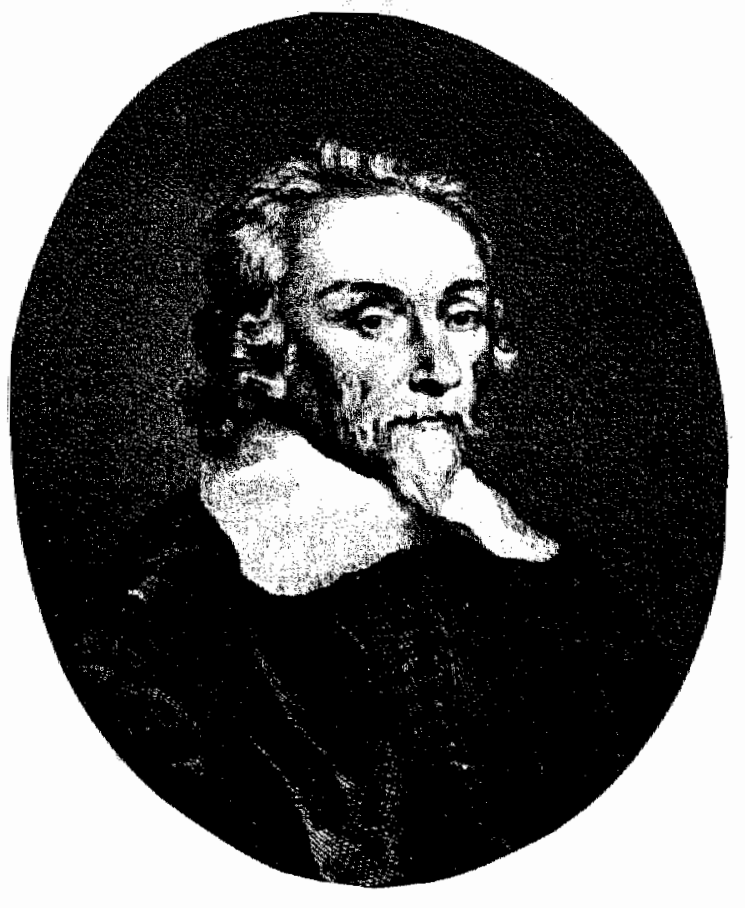

Afb. 2: William Harvey (1578-1657) 
over het proces van de haemostase kwam van Petit in 1731. Hij verklaarde de wondgenezing door aan te nemen, dat er aan de binnenzijde wan de defecte vaatwand, een hieraan hechtend stolsel onstaat, dat aan de buitenzijde door een verstevigd stolsel wordt ingesloten en afgedicht. Over de oorzaak van het ontstaan van een stolsel, laat hij zich echter niet uit. Vijf jaar later in 1736 gaf Morand een total andere verklaring. Volgens hem zou de contractie van de vaatwand in de lengterichting! het lumen van de betreffende arteriën zo sterk verkleinen, dat hierdoor de bloedstolling onmogelijk wordt.

Pas in 1805 trachtte Jones beide theorieen met elkaar in overeenstemming te brengen en verklaarde dat zowel het één als het ander plaatsvond, zij het dan dat de door Morand gestelde contractie van de vaatwand niet in de lengterichting, maar in de dwarsrichting moest plaatsvinden. Over de wederzijdse beinvloeding van haemostase en de bloedstolling blijft men uiterst vaag. Albrecht von Haller stelde in 1757 dat aan het stollingsproces een scheiding van de bloedbestanddelen ten grondslag ligt, die zou ontstaan door het ontbreken van een regelmatige stroming. Hoe modern dit inzicht lijkt in het licht van recent onderzoek over "shear-stress" en bloedplaatjes, toen ter tijd was het niet meer dan een intelligent gissen, mogelijk ook een onduidelijke vorm van een vitalistische verklaring van de bloedstolling, die ook na won Haller nog geregeld zal opduiken. In Engeland toonde William Hewson ${ }^{1}$ in 1773 aan, dat rust geen stolling veroorzaakt, daar het bloed in een afgesloten arterie van een hond na $45 \mathrm{~min}$. nog niet stolt, terwijl het buiten het dier in $7 \mathrm{~min}$. volkomen gestold is. Hij neemt als inlleiding tot de stolling het contact met de lucht aan, daar het inbrengen van lucht in een arterie, het bloed snel tot stolling brengt. Stilstand zou stolling alleen versnellen. Zelfs Schröder van der Kolk die in 1820 zijn eerdergenoemde, eerste historische over-

${ }^{1}$ William Hewson 1739-1774 was een leerling van Hunter en in zijn tijd een beroemd chirurg die in Londen leefde en werkte. Hij is verder bekend door zijn publikaties over het lymphvatensysteem bij mens en dier en de leucocyten. 
zicht over het stollingsonderzoek schreef, nam nog aan dat de vloeibare toestand van het bloed alleen door de bloedstroming in stand werd gehouden.

Alle oude theorieën, zoals stolling door afkoeling, door verdamping bij blootstelling aan de lucht of ook door stagnatie van de bloedstroom in de aderen, die reeds ten dele door het werk van Hewson en Hunter ongeldig werden, zijn eerst door Brücke in 1857 geheel weerlegd op kennelijk voor zijn tijdgenoten bevredigende wijze. Na zijn werk komt men de oude theorieën niet meer tegen. Brücke wees ook op de grote rol die de vaatwand speelt bij het vloeibaar blijven van het bloed. In hetzelfde jaar toonde hij in zijn bekend geworden proef aan, dat het bloed van een hond die door verstikking was gestorven, na zeven uur en vijfendertig min. nog vloeibaar was. Of het later wel stolde vermeldt hij niet, hetgeen jammer is omdat het niet onwaarschijnlijk is dat hier fibrinolyse was opgetreden zodat de proef op zichzelf weinig zegt. In het geisoleerde hart van de schildpadsoort Emys oricularis (Linne), vond hij in 1758 , bij $24^{\circ} \mathrm{C}$ na één dag en bij $1^{\circ} \mathrm{C}$ na acht dagen geheel ongestold bloed, daar vermeldt hij dat het bloed na punctie wel stolde.

In tegenstelling tot de vitalistische en natuurkundige theorieën ontstaan er in het begin van de $19 \mathrm{e}$ eeuw physisch-chemische theorieën, gebaseerd op de analogie tussen bloedstollingen en het neerslaan van eiwit. Zo dacht Thackrah in 1820 , dat het eiwit in het bloed door een basische stof in oplossing wordt gehouden en dat bij een bloeding waarbij het buiten het lichaam treedt, het koolzuur-gas uit de lucht, deze basische stof neutraliseert, waarbij het eiwit vrijkomt en als fibrine neerslaat. Zo werd bloedstolling verklaard als een fysisch-chemische precipitatie van eiwit toegeschreven an het verdampen van water en ammonia uit het uitstromende bloed.

Zoals gezegd is het soms moeilijk chemische en vitalistische verklaringen geheel te scheiden zoals bijvoorbeeld bij die onderzoekers, die de stolling zien als een "galvanisch gebeuren" waarbij een "electrisch" precipitaat ontstaat en dit alles in een tijd waarin de begrippen "galvanisch" en "electrisch" nog zeer slecht gedefinieerd zijn. Deze gedachten liggen dicht 
bij een vitalistische verklaring. Men vergelijke b.v. het "magnetisme" van de hypnotische experminenten van Mesmer. ${ }^{2}$

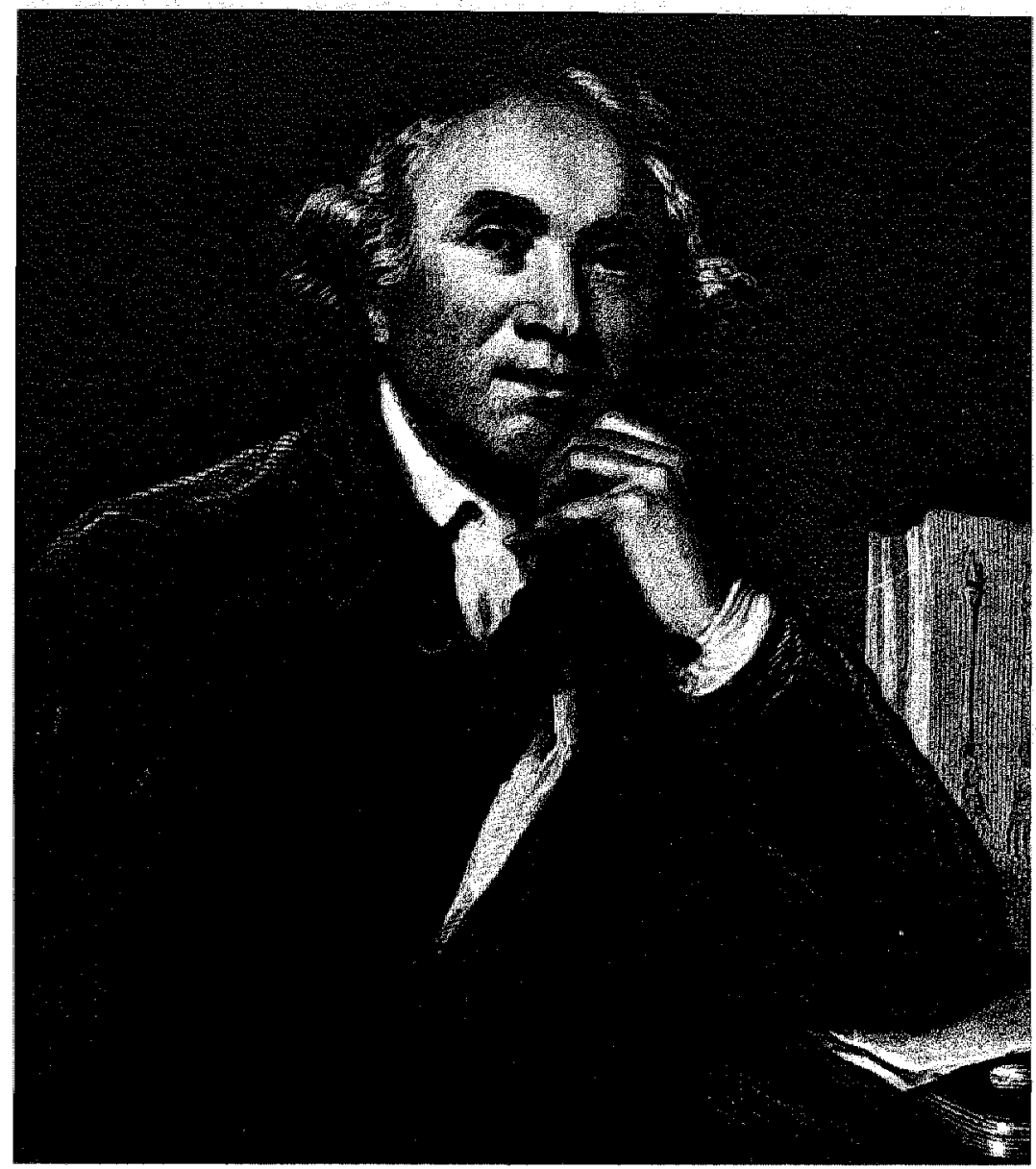

Afb. 3: John Hunter (1728-1793)

${ }^{2}$ Franz Anton Mesmer werd in 1734 te Weiler bij de stad Stein aan de Rijn geboren. Hij was de eerste schrijver over "dierlijk magnetisme", naar hem ook "mesmerisme" genoemd. Mesmer studeerde te Wenen onder de leiding van de beide grote leerlingen van Boer- 
Aan de andere kant beweert John Hunter (1728-1795) dat het samentrekken van het stolsel een electrisch gebeuren is, dat geheel vergelijkbaar is met de spiercontractie en leidt daaruit af dat de gehele stolling op een electrisch verschijnsel berust. Alles in een betoog waarin men met moeite een vitalistische inslag terug zal vinden.

G. Andral $(1829)^{3}$ en G. Forget (1835) zeiden dat de stolling met eenvoudige chemische en natuurkundige wetten kon wordeb verklaard en dat het dus niet nodig was er vitalistische verklaringen voor te geven.

Tegen de achtergrond van het vitalisme werd er dus wel degelijk gewerkt om voor het stollingsgebeuren een meer reeële basis te vinden. Een groot nadeel van de al eerder genoemde slechte communicatie tussen onderzoekers is o.a. ook dat goede theorieën, gebaseerd op zorgvuldige waarnemingen, hierdoor te wejnig aandacht krijgen, daardoor snel in het vergeetboek terecht komen en de competitie met minder gefundeerde beweringen, die met meer aplomb gedaan worden, verliezen.

haave, Stoll en de Haen. Onder toezicht van de Haen schreef Mesmer zijn dissertatie: Over de invloed der planeten op het menselijk lichaam, in 1766. Dit proefschrift was de wegwijzer voor de richting die Mesmer in zijn leven zou inslaan. Hij deed proeven met magneten op het menselijk lichaam. Tegelijk met hem deed Hell, hoogleraar in de sterrenkunde dezelfde proeven en deze meende te hebben gevonden dat de magneten bij bepaalde ziekten toegepast, de zieken zo niet genazen dan toch een verbetering bewerkstelligden. Mesmer herhaalde deze proeven doch ontdekte dat de kracht niet in de magneten doch in hemzelf zetelde. Een kracht die naar zijn inzien, vreemd, nieuw en nog nooit beschreven scheen te zijn.

Hij kon met die kracht zeer afwisselende verschijnselen te voorschijn roepen, ziekten doen ophouden, naar willekeur aantrekken of afstoten en noemde haar juist om deze eigenschap "dierlijk magnetisme".

De stijl die al wat Mesmer geschreven heeft kenmerkt is mystiek en onverstaanbaar voor iedereen die niet thuis is in de natuurphylosofische redeneringen van die tijd. Door de medische faculteiten van Parijs en Wenen werd hij als kwakzalver beschouwd. Hij overleed 5 maart 1815 te Mespurg op 81 jarige leeftijd.

${ }^{3}$ Gabriel Andral, med. te Parijs 1797-1876. 


\section{Cellen of plasma?}

Een van de belangrijkste strijdpunten in de vroege theorievorming over de bloedstolling is de vraag of de stolling uitgaat van bloedcellen of van het plasma. Het is een vraag die overigens tot op de dag van vandaag doorklinkt in de discussies over de pathogenese van de venueze en arteriele thrombose. Zoals bij zovele heftige controversen op het wetenschappelijk vlak blijkt uiteindelijk iedereen gelijk te hebben, de tegenstanders zien echter in het begin, door een gebrek aan overzicht, leder slechts een ander deelgebied.

Marcello Malphigi 1628-1694 zag reeds verschil tussen bloedplasma, dat de fibrinekorst vormt en de door het fibrinenet ingesloten bloedlichamen. Als hij bloed afkoelde vertraagde hij hiermede de stolling, (zoals we al eerder in par. 2 zagen) de bloedlichamen vormden een sediment en langzamerhand vormde zich een celvrije korst aan de oppervlakte. Als hij deze mikroskopisch onderzocht, zag hij een dradennet waarin geen cellen voorkwamen. Hij verklaarde dit gebeuren echter zuiver mechanisch. De "atomen" van het fibrine werden door de stroming van het bloed gescheiden en konden pas buiten de bloedbaan met elkaar in contact komen. Bij het volgen van de discussies over de rol van cellen en plasma is het belangrijk om te onderkennen dat de belangrijke rol van de bloedplaatjes eerst in 1882 door Giulio (Julius) Bizzozero werd ontdekt en benoemd in het klassieke artikel over de thrombocyten waarin ook de interessante discussie van Bizzozero over de zienswijze van Alexander Schmidt voorkomt waarop we later terugkomen.

De in par. la genoemde Hewson toonde in 1772 aan, dat in zeer langzaam stollend bloed (hiertoe voegde hij natrium sulfaat toe), waarin de aanwezige cellen snel sedimenteerden, de stolling niet van de aanwezige cellen, doch van het ër bovenstaande plasma uitging. Verder vond hij dat bloed in een afgesloten arterie bevroren en weer ontdooit, niet stolt. Buiten de arterie en bij kamertemperatuur stolt het na enkele minuten. 


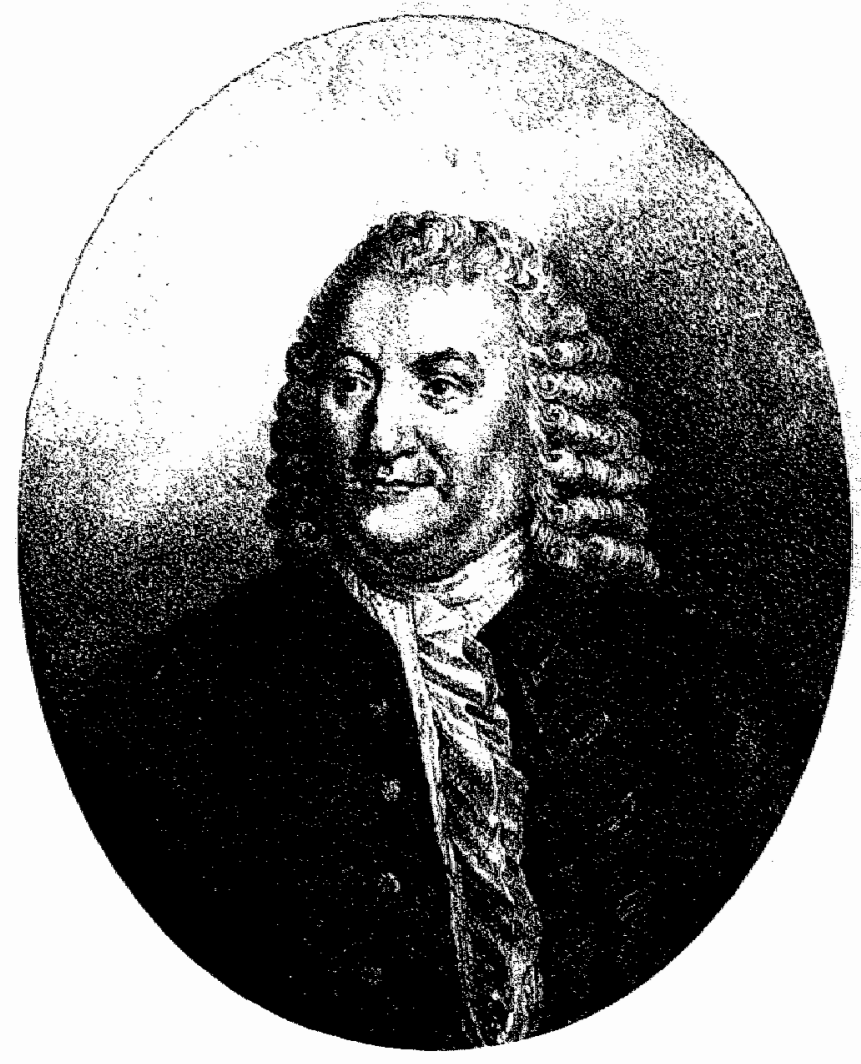

Afb. 4: Albrecht von Haller (1709-1777) 


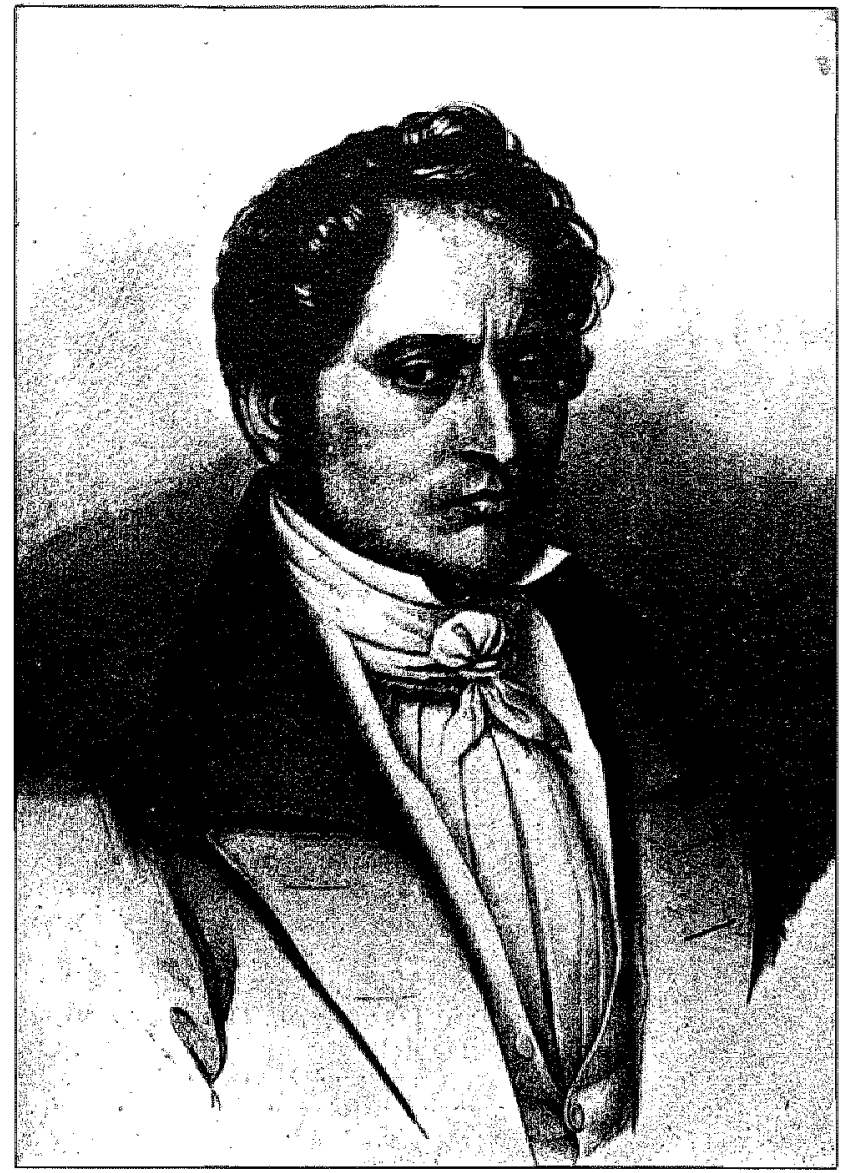

Afb. 5: Johannes Mueller (1801-1858) 
Pas in 1832 publiceerde Johannes Müller zijn beroemd geworden proef waarin hij op het bestaan van de stollingsstof in opgeloste toestand wees. Hij experimenteerde met iymphe en bloed van de mens en van de groene kikker (Rana esculenta) en zegt hierover o.a. (pag. 516).

Diese Versuche vom Frosch liefern die Bestätigung jener Beobachtung van der menschlichen Lymphe. Es ist sehr instructiv, unter dem Mikroskop die Entstehung des Gerinsels in einem Tropfen Froschlymphe zu untersuchen, wo man sich auf das Bestimmteste überzeugen kann, dass die hier in ganz grossen Zwischenräumen zerstreuten Kügelchen gar keinen Anteil an der Gerinnung des vorher aufgelösten Faserstoffs haben. Op p. 537 gaat hij als volgt verder:

Berzelius hat indess aus dem Umstande, dass die Lymphe aufgelösten Faserstoff enthält, vermuthet, dass, auch das Blut aufgelösten Faserstoff enthalten müsse, weil die Lymphe gleichsam eine von dem Blute abgeseihete Flüssigkeit sey. Man könnte als noch triftigeren Grund hinzufügen, weil die Lymphe selbst in's Blut gelangt.

Berzelius stellte daher vermuthungsweise die Ansicht auf. dass beim Gerinnen des Blutes der im Blut aufgelöste Faserstoff fest werde und die Blutkörperchen zwischen sich nehme. Diese Ansicht, dass der Faserstoff im Blut aufgelöst ist, ist schon zu verschiedener Zeit proponirt worden.

Ich bin so glücklich gewesen, einen definitiven Beweis für Berzelius' Vermuthung zu finden, und bin im Stande, zu zeigen, dass das rothe Coagulum des Blutes nur ein Gemenge von Faserstoff, der vorher aufgelöst war, und von Blutkörperchen ist. En hij vervolgt:

Ehe ich aber die entscheidenden Versuche hierüber mittheile, möge mir erlaubt seyn, auch meine fruchtlosen Bemühungen zur Entscheidung jener Frage zu erwähnen.

Hij beschrijft dan zijn mislukte proeven en zegt dan:

Und nun freue ich mich, durch einen leichten Versuch in den Vorlesungen zeigen zu können, dass Faserstoff im Blut aufgelöst ist, der wasserhell durch's Filtrum geht und dann gerinnt. Der Versuch lässt sich ganz im Kleinen mit dem Blute eines 
einzigen Frosches anstellen; ein kleines gläsernes Trichterchen und ein Filtrum von gewöhnlichem weissen Filtrirpapier oder nicht zu dünnen Druckpapier sind das Einzige, was man nöthig hat. Das Filtrum muss natülich vorher nass seyn, und es ist gut, wenn man das eingegossene frische Blut des Frosches schnell mit eben soviel Wasser versetzt.

Was dann von dem Filtrum abfliesst, ist ein fast ganz farbloses, klares Serum von Wasser verdürnt, mit einem ganz leïchten Anflug von Roth, wie Blutroth, welches vom zugesetzten Wasser aufgelöst worden ist. Da indessen die Auflösung des Blutroths von Froschblut durch Wasser ziemlich langsam geschieht, so ist das Durchgeseihte. kaum rötlich zu nennen, undzuweilenganz farblos. Wendet man statt des zugesetzten Wassers vielmehr Zuckerwasser an $(1$ Theil Zucker auf 200 Theile und mehr Wasser), so wird während der Filtration gar kein Blutroth aufgelöst, und das Durchgehende ist vollkommen farblos und ohne die geringste Spur einer Beimischung.

Untersucht man das durchgehende Serum mit dem Mikroskope, so bemerkt man keine Spur von Kügelchen darin. In diesem klaren Serum entsteht nun innerhalb einiger Minuten ein wasserhelles Coagulum, so klar und durchsichtig, dass man es nach seiner Bildung nicht einmal bemerkt, wenn man es nicht mit einer Nadel aus der Flüssichkeit hervorzieht. Nach und nach verdichtet es sich und wird weisslich fadenartig, es sieht dann gerade so aus, wie das Coagulum der menschlichen Lymphe in meinen Beobachtungen. Auf diese Art erhalt man den Faserstoff von Blut in reinsten Zustand, wie er bisher nicht dargestellt werden konnte.

De vraag hoe de omzetting van fibrinogeen tot fibrine plaatsvindt, laat Müller onbeantwoord.

De opvatting van Everard Home, 1818 was, dat er bij de bloedstolling zowel chemische als morphologische veranderingen plaats vinden. Naar zijn opvatting bestaan de rode bloedlichamen uit een fibrinekern met een gekleurd omhulsel. Bij het uitstromende bloed komt de kern vrij. De vrije kernen zouden dan het stolsel vormen. Dergelijke voorstellingen van de bloedstolling blijven de gehele negentiende eeuw opgeld doen, zelfs tot George Hayem (1889) die het vrijkomen van fibrinogeen 
uit erythrocyten aanneemt en Bürker 1904 die dèze functie aan de thrombocyten toeschrijft. Hij ging uit van het bovengenoemde artikel van Bizzozero (1882) waarin deze o.a. zegt: Nun ergab die mikroskopische Untersuchung auch hier in allen Fallen, dass so lange das Blut im Gefässe flüssig bleibt, die Blutplätchen ihre normale Form bewahren.

En verder: Der Grundversuch zum Beweise der gerinnungserzeugenden Thätigkeit der Blutplättchen besteht im Folgenden: Man schlägt eine Minute lang einige Tropfen frisch aus der Ader gelassenen Hundenblutes mit vier Zwirnfäden von circa $1 \mathrm{~cm}$ Länge; alsdann zieht man die Fäden aus dem Blute aus, wäscht sie, indem man sie rasch und wiederholt in zwei mit 0.75 procentiger Kochsalzlösung gefüllte Uhrgläschen taucht, und bringt sie darauf in eines der Röhrchen mit proplastischer Flüssigkeit. Untersucht man jetzt einen der Zwirnfäden unter dem Mikroskope, so findet man ihn von dicken Schichten Blutplätchen nebst einer gewissen Anzahl weisser und rother Blutkörperchen, die durch das Waschen nicht abgespühlt werden.

${ }^{4}$ Over de samenstelling hiervan laten we Bizzozero (1882) zelf aan het woord op pag. 317 van zijn artikel lezen we:

Da verfiel ich auf den Gedanke, direct den Einfluss der Blutplättchen auf eine proplastische Flüssichkeit zu prüfen, d.h. auf eine Flüssigkeit, welche wohl die beide Faserstoffgeneratoren (fibrinogen und fibrinoplastische Substanz), aber kein Gerinnungsferment enthielte, so dass Sie nur auf Zusatz von solchem zu gerinnen im Stande wäre.

Die propalistische Flüssigkeit, der ich mich bei allen meinen diesbezüglichen Versuchen bediente, bereitete ich nach den Vorschriften von A. Schmidt (1872). Ich nahm nehmlich an einem kalten Februartage 1 Theil 28 procentiger lösung schwefelsauer Magnesia und fing darin 3 Theile Pferdeblut auf, das in breiten Strahle aus einer geöffneten Halsvene spritzte, Während das Blut in die Lösung floss, rührte ich das Gemenge fortwährend mit einem Glasstäbchen um. Alsdann liess ich die Flüssigkeit bei einer Temperatur von wenig über $0^{\circ}$ ruhig stehen. Nach 24 Stunden hatte sie sich in zwei Schichten geschieden eine untere dunkler welche die rothen Blutkörperchen enthielt und eine obere durchsichtige, durch Hämoglobin leicht roth gefärbte Schicht. Ich hob nun voorsichtig mittelst eines Hebers den durchsichtigen Theil ab und filtrite ihn bei $a^{\circ}$. Das Filtrat stellte die proplastische Flüssigkeit dar. 
konnten, überzogen. Nach 12 bis 14 Stunden seit dem eintauchen der Fäden in die proplastische Flüssichkeit ${ }^{4}$ hat sich bereits in derselben ein ansehnliches Faserstoffgerinsel gebildet, das bald nur die Fäden überzieht und mit einander verklebt, bald auch eine Schicht von $1 \mathrm{~mm}$ Dicke und darüber am Boden des Probierröhrchen bildet, bald endlich (und das kommt oft vor) die ganze Flüssigkeitssäule einnimmt. Sind die Blutplattchen an den Fäden zahlreich, so erfolgt die Gerinnung rascher und ergiebiger.

Wij moeten dus tot de conclusie komen dat de verhouding van de bijdrage van het plasma en van de vormbestanddelen van het bloed aan de bloedstolling de gehele negentiende eeuw niet geheel is opgehelderd. Is het echter omstreeks 1800 nog een vrij duister twistpunt, omstreeks 1900 is de grote meerderheid van de onderzoekers het erover eens dat fibrinogeen opgelost in het bloed voorkomt, en dat thrombine en prothrombine oplosbare stoffen zijn die mogelijk wel uit het bloed of weefselcellen afkomstig zijn, maar die in opgeloste toestand werkzaam zijn.

Met name het feit dat de invloedrijke Virchow de mening was toegedaan dat een voorstadium van de "vezelstof" in plasma was opgelost, heeft er veel toe bijgedragen dat de correcte visie gemeengoed werd.Virchow is ook degene geweest die de naam fibrinogeen heeft voorgesteld. 
1c Fibrine of fibrinogeen?

Omstreeks 1845 dacht men algemeen dat de stollingsstof "spontaan" in vaste toestand kon overgaan, d.w.z. daartoe aangezet door stilstand, afkoeling, luchtcontact etc., zoals in eerdere paragrafen omschreven.

Virchow (1862) veronderstelde dat de stollingsstof (fibrine dus) niet vloeibaar in het bloed kon voorkomen, doch daarin als een andere stof met geheel verschillende eigenschappen aanwezig zou zijn. Hij gaf in 1847 aan deze stof de naam fibrinogeen. Argumenten voor deze naamgeving hebben wij in geen van zijn vele artikelen kunnen vinden. Wel zegt hij in zijn publicatie "Zur pathologischen Physiologie des Blutes" in het door hem met B. Reinhardt opgerichte Archiv für pathologische Anatomie und Physiologie und für klinische Medicin, Bd 1 (1847) op pag. 581: Wir kommen also hier zu dem wahrscheinlichen Resultat, dass in dem Exsudat nicht ein besonderer, qualitativ verschiedener Faserstoff existiert, der sich von anderem durch seine späte Gerinnungszeit unterscheidet, sondern dass darin eine Substanz sich befindet, die unter der Einwirkung der atmosphärischen Luft sich in den gerinnungsfähigen Faserstoff umwandelt. Man hat gar keinen Grund dazu, diese Substanz Faserstoff zu nennen; vielmehr, wollte man sie benennen, so könnte man sie höchstens $F i b r i n$ o $g$ e $n$ taufen. Denis trachtte in 1856 door uitzouten uit plasma, als eerste, het fibrinogeen van Virchow zuiver te verkrijgen. Hij maakte op deze wijze een neerslag van eiwit, dat na oplossen weer spontaan stolde. Het principe van deze methode, waarbij hij dus door uitzouten een fractionering van de stollingseiwitten verkreeg, hetgeen voor de ontwikkeling van het stollingsonderzoek belangrijk genoemd mag worden, schijnt te dien tijde in de vergetelheid te zijn geraakt, weer één van de vele voorbeelden van de slechte communicatie die de verschillende onderzoekers op dit gebied met elkaar hadden. 
Vooral in het begin van zijn loopbaan achtte Virchow (1847) het contact met de lucht nog van groot belang voor het op gang brengen van het stollingsgebeuren. Een duidelijke voorstelling van het mechanisme heeft hij niet. Zijn zienswijze in deze berust hoofdzakelijk op praktische overwegingen. $\mathrm{Na}$ te hebben gezien dat het stolsel uit fibrine bestaat, (Die durch die Gerinnung gewonnene Substanz zeigt alle Eigenthümlichkeiten des gewöhnlichen Faserstoffs) bespreekt hij een paar mogelijkheden waardoor stolling kan zijn opgetreden, doch verwerpt deze weer direct. Verder schrijft hij: Es bleibt also nur übrig, dass die niedigere Temperatur oder die Einwirkung des Luftsauerstoffs angezogen wird. Gegen die erstere lässt sich aber dasselbe sagen, was gegen die blosse Aufhebung hindernder Momente schon angefuhrt ist; die zweite wird dadurch nicht abgewiesen, dass Flüssigkeit die 2 Tage nach der Entlening in ein hermetisch verschlossenes Gefäss gethan wurde, doch gerann, denn sie war schon 2 Tage lang der Einwirkung der Luft ausgesetzt gewesen. Diese Annahme wird insbesonders durch Beobachtungen unterstützt, u.s.w.

In Engeland was het Joseph Lister 1863 die aan deze opvattingen een einde makkte, door met eenvoudige experimenten te bewijzen dat het opnemen of ontwijken van welk gas dan ook, geen belangrijke invloed op het stollingsgebeuren uitoefenden.

Nog eerder, un Schotland had Buchanan inmiddels de proeven gedaan die bewezen dat de overgang van fibrinogeen in fibrine een enzymatisch proces was.

Aan deze belangrijke ontdekking wijden wij het volgende hoofdstuk. 


\section{ANDREW BUCHANAN EN ZIJN WERK}

\section{IIa Het herhalen van historische experimenten}

Het werk van Buchanan kan achteraf worden beschouwd als het eerste onderzoek dat duidelijk maakte dat bloedstolling een enzymatisch proces is. Als zodanig wordt het in historische overzichten dan ook terecht beschreven. Toch komt een Schmidt, die enkele decennia na Buchanan dezelfde proeven deed, tot een andere conclusie. Dit leidt onmiddellijk tot de vraag of Buchanan wel tot de juiste conclusie is gekomen op grond van harde experimentele gegevens en, als dat zo is, of Schmidt zich heeft vergist of een interpretatiefout heeft gemaakt. Omgekeerd bestaat de mogelijkheid dat Schmidt nauwkeuriger waarnemingen heeft gedaan dan het kader waarin hij probeerde te interpreteren toeliet. Een gedeelte van de verwarring die de moderne lezer bekruipt bij het lezen van vroeger onderzoek op het gebied van de bloedstolling vindt zijn oorzaak in de dubbele onzekerheid die ontstaat doordat men, met de huidige achtergrondkennis kijkt naar een proef die geconcipieerd is, gerapporteerd wordt en geinterpreteerd wordt, in een gedachtenwereld die wij wel kunnen navoelen maar waarin wij ons niet meer kunnen verplaatsen. 
Zeker, in de vorige eeuw is het geen bon ton veel van de subjectieve invloeden bij deze processen te laten doorklinken in wetenschappelijke publikaties. Toch kregen we de indruk dat de resultaten in belangrijke mate afhankelijk moesten zijn van

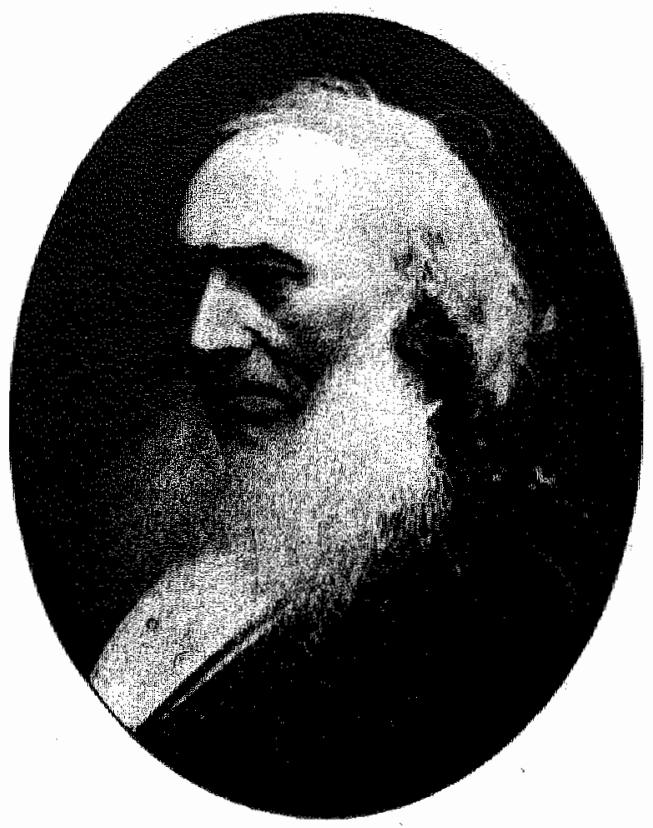

Afb. 6: Andrew B. Buchanan (1798-1882)

een bewuste of onbewuste, maar niet op experimentele gronden berustende voorkeur van de onderzoeker.

Om dit warnet na een eeuw, niet nog eens te overdekken met onze eigen interpretatie hebben we geprobeerd sommige van deze oude proeven te herhalen, te reconstrueren. Daarmee wilden we gegevens verzamelen, in moderne termen en trachten te beoordelen wat vroeger werd waargenomen. Daarmee hoopten we dan ook uit te vinden of de gronden waarop de auteurs tot hun conclusie kwamen alleen experimenteel, of mogelijk ook intuitief of zelfs ongefundeerd waren. 
Omdat de proeven van Buchanan beschouwd worden als het begin van het moderne biochemische onderzoek van de bloedstolling willen wij er bijzondere aandacht aan besteden. Niet alleen willen we ze beschrijven en Buchanans interpretatie bespreken, het leek ons interessant genoeg ze te herhalen en uit te breiden met de mogelijkheden van het moderne onderzoek, zodat we niet alleen een indruk krijgen van wat Buchanan zelf heeft gezien, maar ook zijn resultaten in moderne termen kunnen interpreteren. Dit hebben we niet alleen gedaan met de proeven van Buchanan maar ook met twee andere cruciale onderzoekingen die van Arthus en Pagès en die van Pekelharing.

Het herhalen van oude proeven heeft zijn eigen charmes en moeilijkheden. Voor we met de proeven begonnen hebben wij alles wat door de auteur(s) hierover gepubliceerd was gelezen en herlezen. Dit in de eerste plaats om een zuiver beeld te krijgen over de theoretische achtergronden van de betreffende proef in de denkwereld van de auteur maar vooral ook om de door de oorspronkelijke auteurs gevolgde handelingen op exact dezelfde wijze te kunnen herhalen. Hierdoor ontstaat een redelijke mogelijkheid dat we de door ons gevonden uitkomsten met die vroeger gevonden zijn kunnen vergelijken. Wij mogen aannemen dat de graad van zuiverheid der te gebruiken chemicalien, heden ten dage, door vervolmaking der productiemethoden, groter is dan toen de originele proeven werden gedaan. Al is het ons niet gelukt chemicaliën uit die tijd te vinden, waardoor een vergelijking mogelijk zou worden, verwachten wij van deze zijde geen moeilijkheden, al is het maar omdat plasma zelf zo'n complex mengsel is, dat "gewone" verontreinigingen er van huis uit al in voorkomen. Geheel anders is dit met het verkrijgen van, voor de proeven noodzakelijke niet als chemicaliën gedefinieerde stoffen, de apparaten en de uit te voeren handelingen.

Ten aanzien van bepaalde benodigde stoffen, kan als voorbeeld gelden, het nagaan van de juiste samenstelling en het verkrijgen van huishoudzeep zoals die anno 1890 gemaakt werd, een stof die we voor het herhalen van de proeven van Arthus en Pa- 
gès nodig hadden. Met grote waarschijnlijkheid betreft het hier z.g. zachte zeep, naar ons uit kook- en huishoudboeken van die tijd duidelijk werd. Wat betreft de te gebruiken apparatuur en uit te voeren handelingen wijzen wij hier alleen op het verschil in de handelwijze van bloedafnemen zoals dit vroeger en heden ten dage geschiedt. De huidige "ideale" venapunctie was onbekend, de venen werden met een lancet geopend. Verder blijken er nog wel eens verrassingen op te treden tijdens het herhalen van de proeven zoals later in dit hoofdstuk zal blijken als we stuiten op hydrocele vloeistof waarin fibrinogeen helemaal niet voorkomt, terwijl uit geen enkele publicatie van Buchanan blijkt dat hij heeft waargenomen dat er exudaten bestaan, waarin geen, of slechts sporen fibrinogeen voorkomen. Dit soort moeilijkheden gaat soms zover dat het herhalen van de proeven van een meer "filosofisch" aangelegd onderzoeker als Alexander Schmidt, (die we later nog uitgebreid zullen tegenkomen) welhaast geheel onmogelijk wordt.

\section{Andrew Buchanans werk}

$\mathrm{Nu}$ echter eerst terug naar Buchanan:

Buchanan, die de Schotse nationaliteit bezat, leefde van 17981882 in Glasgow. In deze stad heeft hij ook zijn belangrijke onderzoekingen verricht en wel in de jaren 1820-1850. Hij was verbonden aan het Glasgow Royal Infarmery waar hij begon te experimenteren met de werking van farmaca op het menselijk lichaam. Daarbij mengde hij verschillende stoffen met bloed en vond interessante en onverwachte resultaten, die de aanleiding waren voor zijn latere experimenten. De publicaties over zijn bijdragen tot de kennis van de hemostase, verschenen in "The London Medical Gazette" in de jaren 1836-1845. In zijn eerste proeven liet hij bloed stollen, daarna filtreerde hij het door linnen en voegde van het filtraat iets aan een sereus exudaat toe. Dit mengsel liet hij een nacht staan. De volgende och- 


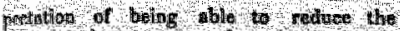

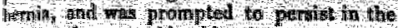

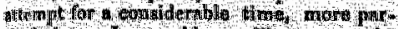

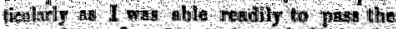

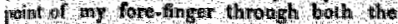

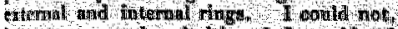

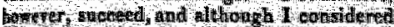

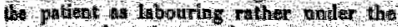

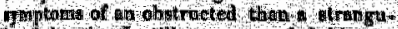

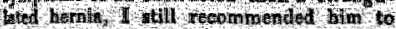

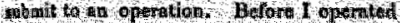

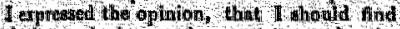

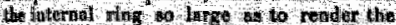

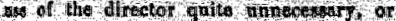

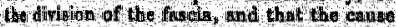

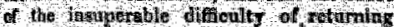

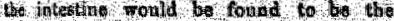

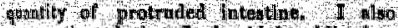

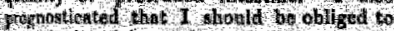

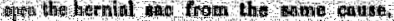

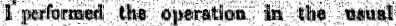

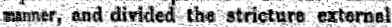

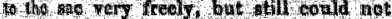

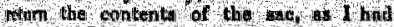

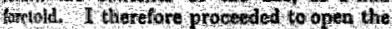

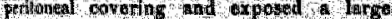

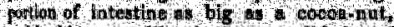

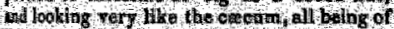

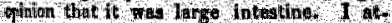

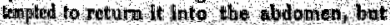

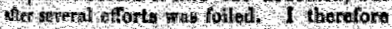

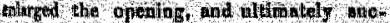

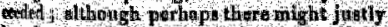

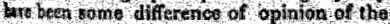

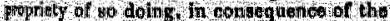

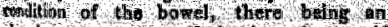

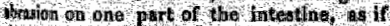

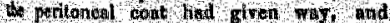

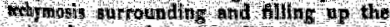

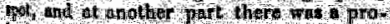

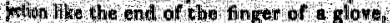

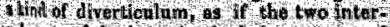

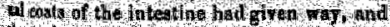

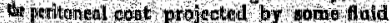

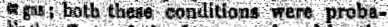

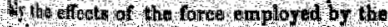

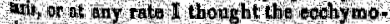

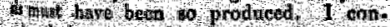
the howerce, that the integtiog anald

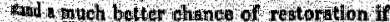

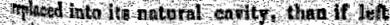

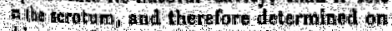

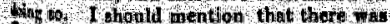

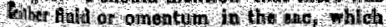

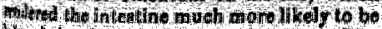

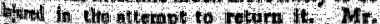

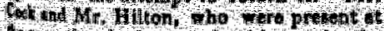

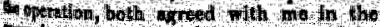

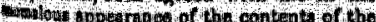

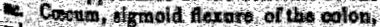

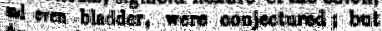

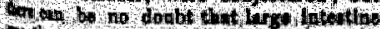

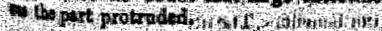
I
Odighat Cominumations

ond $\mathrm{nm}$

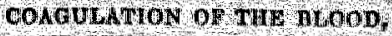

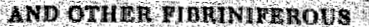
THaUDS

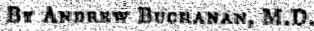

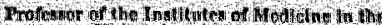

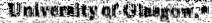

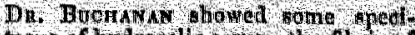

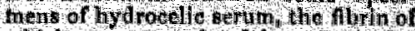
which trius congunted by mente of a

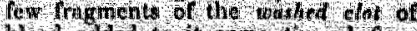

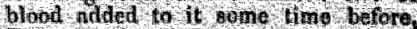

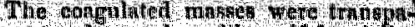
rent and tremulous $1 \mathrm{ke}$ call foot jelly. and so frum as to admith of lecing inrerted on a plane aurfage whthout it ter ing their bhape, Dr. Diachament malle the following olsersitions in oxplinia ton of the jhertomenon.

The oxpentiment oxtubited to the 80 . clety, and the analogons experimente ment loned below, keen to we timmor-

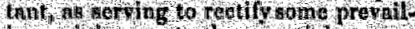
Ing opinions a to the essential yropor. We of fibm, and the part when is phy in the cengulation of the blood,

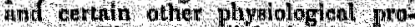
cesser. Thiog and ond1 farther Interesthag to mis as cnabling the to gomreot

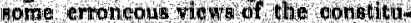
tion of the blood which / encertained, and whicth having teen maide piblio in the first volume of the rproceditig of the boilety I feal It n fiaty to reetify.

The opinions commonly critertained

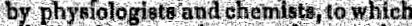
allugion has fuct heen madc, are thot

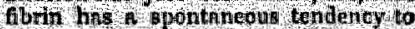
congolate that th th spontha fous ono

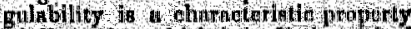

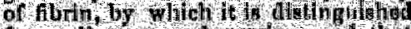

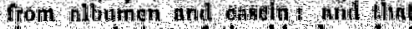

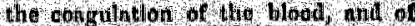

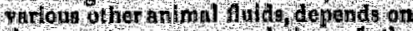

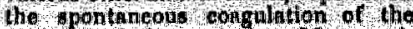
fibrin whieh they oontinn, My oxpert nuent, on the other hind, bhow, hat Abith hims not the least tendener to de-

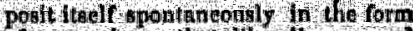
or a wonguluha that, like arbumen and

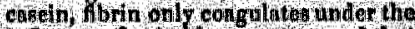
Infinenge of twituble reagents / gad that

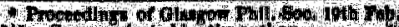

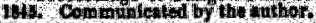


tend had zich hierin een nieuw stolsel gevormd. Toenmaals besefte hij het grote belang van dit experiment niet. Toch had hij hiermede reeds in feite aangetoond, dat thrombine het fibrinogeen in fibrine verandert. Althans een eenvoudiger hypothese kan zijn proeven niet verklaren.

Het exudaat dat hij voor zijn stollingsproeven uitkoos was hydrocelevloeistof, omdat deze bij een relatief gezond mens ontstond. Andere exudaten werden alleen maar bij ernstig zieken aangetroffen en hij dacht dat toepassing hiervan zijn onderzoek alleen maar ingewikkelder zou maken. Toch, al is de hydrocelevloeistof het belangrijkste geweest voor het bloedstollingsonderzoek, heeft Buchanan ook met andere lichaamsvloeistoffen geexperimenteerd.

Eigenlijk is zijn stollingsonderzoek een onderdeel van een meer uitgebreid opgezet werkplan waarin hij probeerde tot een begrip te komen van de functie en onderlinge samenhang van allerlei vochten die in het lichaam voorkomen.

Ten tijde van Buchanan dacht men dat de sereuse exudaten dezelfde samenstelling hadden als serum. Buchanan heeft bewezen dat dit niet zo is, althans dat er sereuse exudaten zijn waarbij dat niet het geval is.

In eerste instantie dacht hij dat het de "colouring matter" van het bloed was, die de stolling veroorzaakte. Hij scheidde hiertoe bij gestold bloed het serum van het stolsel zo, dat het geheel vrij was van bloedcellen en dus helder licht geel. Als hij nu hydrocelevloeistof toevoegde, vond toch stolling plaats. Hiermede bewees hij dat het niet de "colouring matter" was die het bloed deed stollen.

Hierna bestudeerde hij verschillende lichaamsvloeistoffen, om te weten in welke eigenschappen ze verschilden zowel in algemeen chemisch opzicht als in stollingfysiologisch gedrag. Hij vond het verschil vooral in hun gehalte aan "albumine". Tegenwoordig zouden we zeggen totaal eiwit. Het meeste albumine bevatten de pleurale, scrotale, peritoneale en pericardiale vloeistoffen. Dan volgde de intracellulaire weefselvloeistof. Het derde type was de cerebrospinaalvloeistof en ten slotte vormde de vloeistof bij blaren het vierde type. Bij het bepalen van s.g. en stolvermo- 
gen bij verhitting, beide een maat voor het eiwitgehalte, vond hij verschillen tussen transsudaten en exudaten. Hydrocelevloeistof en serum hadden hetzelfde s.g. en stolden bij verhitting, terwijl pleuraalvloeistof, die hij verkreeg van een patiënt die aan pleuritis was gestorven, een s.g. bezat, ongeveer gelijk aan dat van water en niet stolde bij verhitting. Ook stolde het niet als ze met peritoneaal vloeistof of serum gemengd werden. Cerebrospinaalvloeistof, vrij van bloedcellen, heeft een laag soortelijk gewicht, stolt niet bij verwarming, doch verandert van kleurloos naar opaalkleurig.

Vloeistof uit blaren geleek op hydrocelevloeistof in soortelijk gewicht en vermogen om bij verhitting te stollen, maar verschilde er van door niet te stollen als het met serum werd vermengd. Daarom dacht Buchanan dat het misschien een soort serum was dat uittrad bij verwonde vaten.

Deze gedachte werd bevestigd door het feit, dat als hij vloeistof uit blaren met hydrocelevloeistof mengde, het geheel ging stollen.

Hij verklaarde het stolsel dat op een verwond oppervlak ontstaat door te veronderstellen dat er een tweede type vloeistof is, die met vloeistof uit blaren stolling veroorzaakt. (Beiden kwamen dóór de beschadigde huid).

Op basis van eerdere bloedstollingsexperimenten en onderzoek van lichaamsvloeistoffen ontwikkelde hij een beeld over de functie van het lymphatische systeem en zijn betrekking tot deze vloeistoffen.

In de eerste plaats weerlegde hij het dwaabegrip van Magendie c.s., dat sereuse afscheidingen en vet door hun fysische eigenschappen van grote waarde voor de lichaamseconomie zouden zijn. De belangrijkste functie van lichaamsvloeistoffen en vetten zou nl. zijin om ingewanden, spieren enz. te "smeren".

Buchanan was het hiermede niet direct oneens, maar hij beweerde als eerste dat de lichaamsvloeistoffen in lichaamsholten en tussen de weefsels, niet ter plaatse bleven maar circuleerden en doorlopend in de bloedstroom werden opgenomen en weer afgescheiden, waarbij transport van cellen en stoffen zo goed als stolling tot de functies behoorden. 
Buchanan ontwikkelde verschillende theorieën over de circulatie van de lichaamsvloeistoffen. De eerste was dat zulke vloeistoffen weer werden opgenomen door de lymphvaten. Toen hij deze veronderstelling uitwerkte, stond deze tegenover die van Magendie c.s. die meende dat resorbtie door de aderen plaats vond omdat ze niet in staat waren te laten zien dat de resorbtie van vloeistoffen uit de peritoneaalruimte of van maag en darmen door de lymphvaten geresorbeerd werden.

Buchanans tweede veronderstelling was, dat er een verbinding was tussen de arteriën en de lymphvaten waardoor een deel van het bloed in de lymphvaten kon komen. Ook vond hij het waarschijnlijker dat er een directe dan een indirecte verbinding bestond.

Zijn derde veronderstelling was dat zowel de "membranous" als de "sanguineous" vloeistof in het lymphvatensysteem kwamen, waar ze in de lymphvaten gemengd zouden worden om de lymphe te vormen. Hij wist dat "membranous" en "sanguineous" serum niet stolden, maar een mengsel van beide wel en hij concludeerde dat lymphvloeistof die spontaan stolde een mengsel van beiden was.

Ook merkte hij op dat het lymphatisch systeem zeer geschikt was om twee vloeistoffen te mengen, omdat het een complex netwerk van vaten heeft. In 1845, toen hij Professor of the Institutes of Medecine aan de Universiteit van Glasgow was, werd een lezing van hem door de Glasgow Philosophical Society in The London Medical Gazette gepubliceerd.

Hierin vertelde hij over vroegere experimenten die hij gedaan had, maar in plaats van bloed door een linnen lap te filtreren, verkreeg hij het actieve stollingsprincipe door het stolsel uit te wassen. Het grote belang van deze experimenten ligt, behalve in de waarnemingen die hij daarbij deed, vooral in de uitleg die hij eraan gaf en de conclusies die hij eruit trok.

Toenmaals dacht men dat bloed en andere lichaamsvloeistoffen die spontaan stolden, dit deden omdat ze fibrine bevatten in een labiele, door de omstandigheden binnen de bloedvaten oplosbaar gehouden vorm.

Buchanan was het hiermede niet eens en beweerde dat de stol- 
ling niet alleen plaatsvond omdat de vloeistof fibrine bevatte, maar dat er bij de stolling stoffen aanwezig waren die het "fibrine" activeerden. Als hydrocelevloeistof voorzichtig werd afgenomen, zonder het met bloed te vermengen, stolde dit niet spontaan. Anderzijds zag hij dat als een weinig bloed zich met hydrocelevloeistof vermengde, er wel spontaan stolling optrad. Evenals de stof uit het stolsel, de stolling van de hydrocelevloeistof veroorzaakte, zou ook het stremsel werken om melk te doen stollen. In dit verband refereerde hij aan het werk van Anderson (1844), die eveneens hierover experimenteerde, maar die de twee vloeistoffen eerst filtreerde, waarbij hij ook na filtratie stolling zag. Hij bewees hiermede dat de stof die op het "fibrine" inwerkte, zowel als het "fibrine" zelf, in opgeloste toestand aan" wezig waren. Er worden ook andere weefseltypen gebruikt om hydrocelevloeistof of gefiltreerd bloed te laten stollen, zoals kalfsvlees, vis, huid en slijmvlies.

Tegenwoordig weten we dat hij weefsels toepaste waarin weefselthromboplastine voorkomt. Deze proeven en hun resultaten kunnen ons ook heden nog in verwarring brengen, ofschoon we wel beschikken over een kader waarbinnen de correcte oplossing gevonden wordt. Enerzijds stolt hydrocelevloeistof (een fibrinogeenoplossing?) doordat men er een stolsel of serum (sporen thrombine) aan toevoegt. Anderzijds bestaat de mogelijkheid dat thromboplastineachtige stoffen voor de stolling verantwoordelijk zijn, omdat, zoals we later zullen zien, er wel degelijk stollingsfactoren in hydrocelevloeistof aanwezig kunnen zijn. Buchanans belangrijkste conclusie is dat:

a. "Liquor sanguinis" (= plasma) van serum verschilt omdat het eerste wel "fibrine" bevat en het tweede niet.

b. Fibrinestolsels ontstaan doordat er in stollend bloed een ferment is dat de stolling aanzet zoals het lebferment de melk moet stremmen.

Beide zijn ongetwijfeld hoekstenen voor ons begrip over de bloedstolling en bovendien, zoals we straks zullen zien, hun tijd ver vooruit. $\mathrm{Zij}$ volgen echter beslist niet uit proeven die eenduidig te interpreteren zijn, en zijn verder ingebed in een grotere theorie die zowel juiste maar ook onjuiste gegevens bevat. Dit 
makt dat men, ofschoon men in alle eerlijkheid Buchanan kan beschouwen als de vader van de enzymatische theorie van de bloedstolling, toch blijft twijfelen bij zo'n toekenning.

Zelf gebruikt hij niet de termen ferment of katalysen behalve één maal in de "Remarks" bij zijn artikel uit 1845, maar zijn analogie met het stremmen van melk laat geen twijfel aan zijn juist inzicht in de aard van deze interactie.

Meer twijfel ontstaat als men zich afvraagt of de gronden waarop tot die analogie wordt besloten wel zo vast zijn. Al uit zijn eigen beschrijving kan men nu niet meer besluiten of hij de thrombinewerking op fibrinogeen heeft beschreven of de invloed van de thromboplastine en/of phospholipiden op de vorming van thrombine. Tekenend is b.v. dat hij beschrijft hoe hersenweefsel een veel groter stollingsbevorderend effect heeft dan andere weefsels, hetgeen sterk in de richting van thromboplastine wijst. Ook zien wij dat als Alexander Schmidt na 1860 onafhankelijk van Buchanan practisch precies dezelfde proeven uitvoert hij tot radicaal andere conclusies komt: nl. dat de (witte) bloedcellen aanleiding geven tot de vorming van het stolsel in hydrocele vloeistof.

Deze onzekerheid is waarschijnlijk geen andere dan de fundamentele onzekerheid die overblijft bij ieder historisch onderzoek. Toch bestuderen we een recent verleden, kunnen we ons nog gemakkelijk verplaatsen in de gedachtenwereld van de onderzoeker en handelt hun onderzoek over een globaal onderwerp waarvan we nu alle vragen die ooit bij hen opkwamen in detail kunnen beantwoorden.

\section{c. Wat heeft Buchanan waargenomen?}

Om iets verder te komen bij het oplossen van de vraag wat Buchanan nu gezien heeft en hoe zijn interpretatie samenhing met en afhing van zijn waarnemingen hebben wij zijn proeven gereconstrueerd en er het nodige modern onderzoek aan toegevoegd. 
Wij namen bloed af bij een pony door incisie in de vena jugularis met een driekantig mesje, zoals dat ten tijde van Buchanan gebruikt werd, verdunden het, lieten het stollen en filtreerden het door een linnen doek, juist zoals door Buchanan beschreven werd.

Het filtraat had de kenmerkende eigenschappen van verdund serum, het bevatte geen fibrinogeen of factor $V(</ 2 \%) 1$ à $2 \%$ prothrombine en 20 à $30 \%$ van de factoren VII en X. Het coagulum bewaarden wij, zoals Buchanan ook deed onder $70 \%$ ethanol. Hiervan moest volgens de beschrijving een stukje aan hydrocele vloeistof worden toegevoegd om dan stolling waar te nemen. Rond 1840 toen Buchanan zijn proeven nam, werden patiënten met een hydrocele altijd gepuncteerd, d.w.z. de vloeistof werd d.m.v. een dun buisje afgetapt. Heden wordt een hydrocele geopereerd, zodat we de vloeistof alleen via een chirurg die de operatie uitvoert of een meestal oudere huisarts, die nog de klassieke therapie toepast, kunnen betrekken. Hierdoor is de hydrocelevloeistof een heden ten dage vrij zelden voorkomende vloeistof. Toch konden we een aantal monsters bemachtigen.

Het was merkwaardig om te zien dat bij het eerste monster hydrocelevloeistof noch met het serum, noch met het coagulum enige vorm van stolling optrad, terwijl een fibrinogeenoplossing wel stolde door toevoeging van coagulum. Bij analyse bleek dat de hydrocelevloeistof die wij als eerste ontvingen geen aantoonbare hoeveelheden fibrinogeen bevatte! Uit Buchanans publicaties blijkt nergens dat hydrocelevloeistof ook wel eens zonder fibrinogeen zou kunnen voorkomen.

$\mathrm{Na}$ enig speurwerk in o.a. Pflüger's Archiv vonden wij in band 18 (1878) in een artikel van Olaf Hammarsten "Ueber das Paraglobulin" pag. 38-116 op pag. 84, waar hij in zijn Versuch X o.a. schrijft:

Das Paraglobin wurde aus einer Hydroceleflüssigkeit, welche nur Spuren von Fibrinogen enthielt, dargestellt u.s.w. en op pag. 85 in Versuch XI o.a.: Das aus einer sehr Fibrinogenarmen Hydroceleflüssigkeit dargestellte Paraglobulin wurde u.s.w. en bij dezelfde proef verder: in keiner der Proben $a, b$ und $c$, trat im Laufe von 60 Stunden ein Gerinsel oder irgend ein Niederschlag 
auf.

Hieruit blijkt dat er ook in de vorige eeuw al hydrocelevloeistof voorkomt die practisch geen fibrinogeen bevat. Dit was voor ons aanleiding om alle monsters hydrocelevloeistof waarop wij de hand konden leggen te analyseren. (zie Tabel I.)

\section{Tabel I}

De stollingsfactorenconcentraties in hydrocelevloeistof.

\begin{tabular}{|c|c|c|c|c|c|c|c|c|c|c|}
\hline Conc. & No & 1 & 2 & 3 & 4 & 5 & 6 & 7 & 8 & 9 \\
\hline \multicolumn{2}{|c|}{ Fibrinogeen } & 1 & 5 & 150 & 125 & 7 & 200 & 105 & 50 & 1 \\
\hline \multicolumn{2}{|c|}{ Prothrombine } & $7 \%$ & $0,1 \%$ & $12 \%$ & $12 \%$ & $1 \%$ & $5 \%$ & $0,1 \%$ & $0,1 \%$ & $3 \%$ \\
\hline \multicolumn{2}{|c|}{ Factor $\mathrm{V}$} & $01 \%$ & $0,8 \%$ & $0,8 \%$ & $0,1 \%$ & $0,1 \%$ & $1 \%$ & $0,1 \%$ & $0,1 \%$ & $0,6 \%$ \\
\hline \multicolumn{2}{|c|}{ Factor VII } & $4 \%$ & $5 \%$ & $2 \%$ & $60 \%$ & $1 \%$ & $6 \%$ & $0,1 \%$ & $0,1 \%$ & $2 \%$ \\
\hline \multicolumn{2}{|c|}{ Factor $\mathrm{X}$} & $1 \%$ & $0,1 \%$ & $7 \%$ & $2 \%$ & $0,1 \%$ & $3 \%$ & $1 \%$ & $0,1 \%$ & $0,1 \%$ \\
\hline
\end{tabular}

De factoren werden bepaald met de op het Biomedisch Lab. van R.L. gebruikelijke methoden (zie b.v. Het Stolboekje 1979, A.D.Muller e.d.).

Doordat verschillende van de monstérs ongekoeld vanuit Leiden en Utrecht werden opgestuurd, kan er niet voor worden ingestaan dat de getallen de ware gehaltes bevatten. Ze duiden echter zeker well een ondergrens aan. Sommige van de hydrocelevloeistoffen (nrs. 4 en 7) bevatten zoveel stollingsfactoren, dat toevoegen van fosfolipiden ze moet doen stollen. Dat bleek ook 
inderdaad het geval. aan $2,5 \mathrm{ml}$ van hydrocelevloeistof $\mathrm{nr} .4$ werd $0,5 \mathrm{ml}$ fosfolipidesuspensie van $1 \mathrm{mg} / \mathrm{ml}$ toegevoegd. $\mathrm{Na}$ een uur was een slap stolsel zichtbaar en na 24 uur zag het eruit als door Buchanan beschreven "calf foot jelly", d.w.z. er was stolling opgetreden.

Moeten wij op grond van onze proefresultaten besluiten dat $\mathrm{Bu}-$ chanan nu eens stolling o.i.v. thrombine, dan weer stolling door toevoeging van thromboplastine en/of phospholipiden heeft waargenomen.

Men krijgt uit deze (en andere) ervaringen de indruk, dat zeker daar waar onderzoekers aan het begin staan van de exploratie van een groot en gecompliceerd terrein, hun succes even vaak een kwestie is van het behendig voorbij zien aan de vele gegevens die niet in hun concept passen als aan het vinden van die proeven die hun concept steunen! 


\section{ALEXANDER SCHMIDT EN ZIJN OPPONENTEN}

\section{a. Levensbeschrijving.}

Terwijl bekende onderzoekers als Buchanan, Hewson, Hunter, Lister, Malpighi, Muller en Virchow zich slechts een deel van hun leven met het stollingsonderzoek hebben beziggehouden, was het Alexander Schmidt die als eerste zijn gehele leven hieraan wijdde.

$\mathrm{Z} \mathrm{ijn}$ geboortedatum is niet met zekerheid bekend, het is 15 of 27 mei 1831. Ook over de plaats waar hij geboren werd, is men het niet eens, Volgens J. Munk ${ }^{5}$ is hij op het eiland Oesel, dat tot Estland behoorde en in de Oostzee in de bocht van Riga ligt, geboren. De meeste auteurs noemen het eiland Moon, dat tussen Oesel en Estland ligt en eveneens tot Estland behoorde, als zijn geboortegrond. Het is echter zeker dat hij een Balt was. Zijn vader Alexander Schmidt was predikant en dientengevolge superintendant van het eiland Oesel. De jonge Alexander bezocht het gymnasium en ontving in 1850 het diploma, met lof. Hij ging

5 J. Munk, Alex Schmidt Deutsche Med. W.schr. 18 (1894) p. 411. 
eerst geschiedenis en later geneeskunde studeren aan de "DeutschRussische Hochschule zu Dorpat".

Dorpat ${ }^{6}$ in het toenmalige Estland is nu bekend als Tartu in het tegenwoordige Easti (Estonshaja S.S.R.). Het ligt hemelsbreed ongeveer $300 \mathrm{~km}$ van Leningrad en Helsinki en $150 \mathrm{~km}$ van zowel de Finse golf als de golf van Riga.

Alexander promoveerde bij Prof.Dr. Carl Schmidt (geen familie, zeker niet zijn zoon) in 1858 tot Dr.med. op een proefschrift getiteld, "Ueber eine Doppelmiszgeburt vom Schaf mit hinterer bis zum Atlas reichender Spaltung"!

Carl Schmidt, patholoog en chemicus werkte samen met de fysioloog Fr. Bidder over stofwisselingsvraagstukken en hierdoor ging Alexander zich meer en meer voor de fysiologie en de fysiologische chemie interesseren. Kort na zijn promotie

- Dorpat, Dorpt of Derpt, in de Russische Taal Goeriew, in 't Estlands Tartolen, nu Tartu in Easti was rond 1890 een stad met 30000 inwoners, in het Russische gouvernement Lijfland a.d. Embach. De Hanzestad is zeer oud. In de $13 \mathrm{e}$ eeuw werd zij door de Russen veroverd, doch kort daarop kwam zij in het bezit van de grootmees. ter der Duitse orde. Later werd zij tot de zetel wan een bisdom verheven door Herman, bisschop van Uggenussa. Toen de Russen in 1558 Dorpat heroverden, vernietigden zij het bisdom en bleven zij in het bezit der stad tot in 1582 geheel Lijfland aan Polen werd afgestaan.

In 1625 werden de Zweden meester in Dorpat, Gustaaf Adolf stichtte daar in 1632 een hogeschool die in 1655 naar Pernau verlegd werd. In 1704 bemachtigden de Russen Dorpat weer. Het aantal inwoners bedroeg in het begin van de $19 \mathrm{e}$ eeuw 3600. De bewoners van het deel van Lijfland waarin Dorpat ligt, stonden vroeger bekend als buitengewoon ruw en aan hun oude afgoden gehecht. Nadat de Zweedse heerschappij over hen had opgehouden, onder welke daar de Christelijke godsdienst zeer was witgebreid, keerden zij tot hun bosgoden terug en offerden op bepaalde dagen ossen, schapen en zwijnen, althans dat vertellen de Duitse overleweringen, die er aangaande de Lijflandse boeren bestaan en oude Duitse volksgedichten die bewaard zijn gebleven.

De hogeschool waar Schmidt doceerde werd in 1802 door Keizer Alexander gesticht. Daarnaast was er in Schmidt's tijd een museum voor natuurlijke historie en van oudheden, een militaire school en een sterrenwacht. Dorpat was kennelijk het intellectuele centrum van Lijfland. 


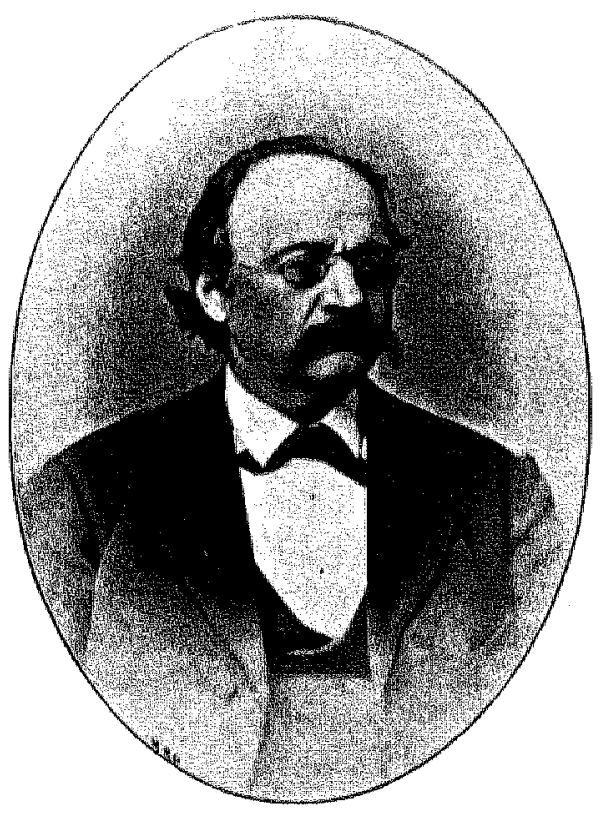

Afb. 8: Alexander Schmidt (1831-1894) 
maakte hij studiereizen naar Wenen, Berlijn, Jena en Tübingen. In Berlijn maakte hij kennis met Virchow en door deze op diens laboratorium met de fysiologie en pathologie van embolie en thrombose, waarvoor hij zich bijzonder ging interesseren. Intussen had hij ook $\mathbb{F}$. Hoppe-Seyler leren kennen die toen hoofd van het chemisch laboratorium van het pathologische instituut in Berlijn was. Hier kreeg Alexander zijn biochemische vorming. Hij werkte er onder Hoppe-Seyler zelf en onder Ludwig en schreef zin eerste publicatie over de bloedstolling in 1861. Interessant is wat hij in deze publicatie op pag. 687 over het experimenteren zegt: Alle diese Versuche sind nicht leicht anzustellen sie miszlingen häufig, in jedem Falle verlangen sie viel Geduld und häufige Wiederholung der Beobachtung, um die rechten Augenblicke niet zu versäumen, verbunden mit groszer Vorsicht. Es wäre zu weitläufig, alle Vebelstände und oft sehr kleinlichen, störende Momente, die die Ursache des Miszlingens werden können, hier angeben $z u$ wollen. Wer sich nicht mit vereinzelten Versuchen begnügt, sondern eine gröszere Reihe derselben anstellt, dem wird es häufig gelingen, oft auch zufällig, das zu sehen, was ich hier beschrieben habe.

Hier zien wij de onderzoeker in alle eerlijkheid toegeven dat er waarnemingen zijn, die door storingen gemakkelijk worden beinvloed. Tussen de regels door lezen wij een zekere twijfel over wat er nu "waarneming" en wat er "storing" is m.a.w. we vermoeden dat Schmidt zich vanaf het begin van zijn onderzoekingen op het gebied van de bloedstolling bewust geweest is, dat een subjectieve keuze de theorievorming beinvloed. Juist zoals wij concludeerden op het eind van het vorige hoofdstuk moet Schmidt hebben gevoeld dat op een dergelijk onoverzichtelijk terrein als de bloedstolling toen was, de tastende vooruitgang in de theorievorming slechts geleid kon worden door de persoonlijke voorkeuren van de pionier die het onderzoek uitvoert.

In 1869 werd Schmidt aan de Universiteit van Dorpat tot professor in de fysiologie benoemd, als opvolger van Bidder. Onder zijn leiding zijn daarna ongeveer vijftig dissertaties over de bloedstolling verschenen. De resultaten van zijn levens- 
werk werden in 1892 in een grote monografie samengevat het toentertijd beroemde "Zur Blutlehre". Schmidt verwierf een niet onbelangrijke naam op het gebied van de hematologie, men noemde hem wel de "vader der bloedstolling".

De toenemende kritiek op zijn werk, noodzaakte hem zijn levenswerk, kort voor zijn dood op 22 april 1894, met een vervolig voort te zetten. Het werd na zijn dood door zijn leerlingen voltooid en in 1895 gepubliceerd.

Schmidt wordt ons beschreven als niet alleen een stimulerend leraar, doch ook als een bijzonder prettig mens. Zijn leerlingen stond hij ook voor particuliere zaken, met raad en daad terzijde. $^{7}$

Hij komt uit zijn werk naar voren als iemand die een brede visie zoekt, die het totaal van bloedstolling en haemostase wil overzien en begrijpen. Iets dat gegeven de stand van kennis in zijn tijd en de achteraf gebleken ingewikkeldheid van de bloedstolling een bijna tragisch, althans een aandoenlijk aspect krijgt. Hij wenst zich niet op te houden met chemisch detailwerk zoals b.y. Hammarsten (zie onder). Het gaat hem om inzicht in de processen die zich bij de stolling afspelen. Hij moet eens gezegd hebben: "als ik een sleutel vindt interesseert het mij niet dat hij van ijzer is, maar ik zoek wel naar het slot waar hij op past".

${ }^{7}$ De persoon Alexander Schmidt leren we beter kennen uit de "Herinneringen van $J$. von Uexküll" wiens vader een jeugdvriend vàn Schmidt was. Zoals von Uexküll zegt heeft hij van Schmidt geleerd "welche Haltung der Forscher im Verkehr mit der Natur einzunehmen hat; bei aller Vertrautheit niemals den Respekt vergessen, der sich dieser groszen Dame gegenüber geziemt".

Volgens Uexküll is: "Schmidt der erste gewesen der das Vorhandensein einer Chemischen Organisation im Körper erkannt hat, die der Mechanischen Organisation gleichberechtigt zur Seite tritt", en ook: "Alles was Schmidt sagte, trug das originelle Gepräge seiner starken und Liebenswürdigen Persönlichkeit; Wenn er erzählte, gewannen die Dinge von den er sprach, eine Goldbraune Tönung wie auf alten Gemälden und wurden dadurch interessant und sympatisch....." Elders zegt hij: "Witz und Humor waren bei Schmidts Familie zu Hause; Den Kulinarischen Genüsse waren Sie zugeneigt. Ein Wunsch- 
Weinig kon hij vermoeden noeveel chemisch detailwerk nodig zou zijn voordat het proces van de bloedstolling enigermate bekend zou zijn. Zijn wisie en experimenten deden het onderzoek na 1860 veel goed. Een gevolg van zijn attitude was echter dat hij nog al gemakkelijk tot niet strikt verantwoorde conclusies kwam. Hierdoor moest hij zijn theorieën regelmatig herroepen. Dit kostte hem soms erg veel moeite en het leidde op den duur tot isolering van hem en zijn school en, wat erger was, ook tot onderschatting van zijn wetenschappelijke verdiensten. Terzijde zij opgemerkt dat we hier een merkwaardig parallel zien met een groot modern onderzoeker; Waller Seegers (geb. 1911). Ook hij weidde zijn gehele leven an de bloedstolling, deed honderden publicaties het licht zien, met veel verrassende experimenten, die achteraf bijna altijd juist bleken te zijn. Zijn interpretatie en theorievorming waren echter, net als bij Schmidt, tegelijkertijd te generaliserend en te ver gezocht, zodat ook hij en zijn school in een geisoleerde positie raakten.

De belangrijkste opponent van Schmidt was wel Olaf Hammersten, die aan de universiteit van Uppsala werkte. Hij werd op 21. Aug. 1841 geboren en overleed in 1932. In 1883 werd hij professor in de medische en fysiologische chemie. Hij publiceerde veel over biochemie en de bloedstolling, in het bijzonder over fibrinogeen. Zijn polemieken met Alexander Schmidt geven een goede indruk van de onzakelijke en onvriendelijke toon waarop toen ter tijd de wetenschappelijke discussie vaak

traum von ihm war es, auf einer Insel der Südsee zu landen, die eine Austernbank besasz. Er wollte dort im Schatten eines Zitronenbaumes sich von Austern ernähren, in die er ein wenig Zitronensaft träufelte, und sich am Anblick der Sonne und des Meeres erfreuen. Die Auster spielte in seinem Leben eine besondere Rolle. Jedesmal, wenn in Dorpat die ersten Austern eintrafen, zog er mit der ganzen Familie zu einem solemnen Austernessen in das Restaurant: "Ich tue das, sagte er, aus moralischen Gründen. Alles in der Welt is relativ. Niemand kan entscheiden, was in diesem Leben wirklich gut oder schlecht ist. Da ist es sehr schwierig, der Jugend den richtigen Halt zu geben. Deshalb führe ich meine Familie hierher. Denn eines ist sicher; die Auster ist gut". 
gevoerd werd. Schrijft hij in 1875: Die Versuche und Beobachtungen von Alex. Schmidt stimmen mit der in dem vorigen Paragrafen ausgesprochenen Ansicht gut überein: twee jaar later in 1877 zegt hij: und in der That kamn man auch gegenwärtig mit Recht einwenden, dass ein Uebergehen des Paraglobulins in den Faserstoff, trotz der Behauptungen Schmidt's, noch nie bewiesen wurde.

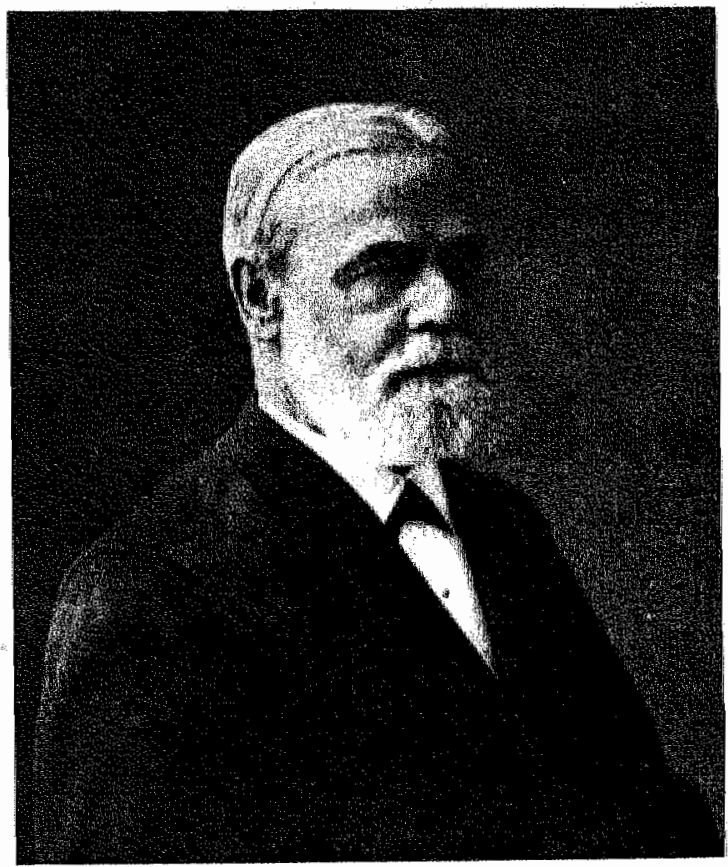

Afb. 9: Olof Hammarsten (1841-1932) 
En verder: Wegen der Wichtigkeit des Gegenstandes habe ich meine Untersuchungen fortgesetzt, und da sie nun gewissermassen zu einem Abschlusse gekommen sind, beabsichtige ich auch, sie bald in diesem Archieve unter Hinweisung auf meine frühere Abhandlungen zu verôffentlichen. Dies ist mir aber nunmehr nicht möglich, weil mittlerweile von Alex. Schmidt in diesem Archieve einige Bemerkungen zu meiner Abhandlung veröffentlicht worden sind. In diesen Bemerkungen berichtet er nämlich über meine Versuche und die Art meiner Beweisführung in einer unvollständigen oder unrichtigen Weise, die jedenfalls diejenigen Leser, welche meine schwerzugängliche Abhandlung nur durch Referate kennen, irre führen könnte. Unter diesen Umständen kann ich nicht mit nur einer Hinweisung auf meine frühere Abhandlung mich begnügen, und da meine neuen Untersuchungen als Fortsetzung der früheren anzusehen sind, muss ich vielmehr, bevor ich zur Darlegung der neugewonnenen Versuchsresultaten gehe, etwas näher auf die Bemerkungen Schmidt's eingehen, damit es dem Leser möglich werde meine Stellung zu der Gerinnungsfase richtig zu beurteilen.

Deze toon, die men nu soms nog in ingezonden brieven in wetenschappelijke tijdschriften tegenkomt, "buiten verantwoordelijkheid van de redactie" wordt tegenwoordig uit artikelen waarschijnlijk door het tegenwoordig algemeen toegepaste referentensysteem en door ingrijpen van de redactie, geweerd. Dat zal in de vorige eeuw minder het geval geweest zijn, getuige de overgeleverde uitspraak van Virchow.

"In meiner Zeitschrift kann sich jeder blamieren wie er will".

\section{b. Schmidt's inzichten over de bloedstolling}

Alexander Schmidt is hoewel een omstreden, toch zeker de centrale figuur, in het bloedstollingsonderzoek van de twwede helft van de vorige eeuw. Om de verdiensten van Pekelharing in relief te zetten kunnen ze niet beter geschetst worden dan tegen de achtergronden van het werk van Schmidt. De theo- 


\section{Ueber den faserstofí und die Ursachen seiner \\ Geriumme.}

Von

Dr. Alex. Schmidr zu Dorpat.

So zahlreich die Untertuchungey sind, die man zur Beantwurtuug der uralten lirage nach Listuche und Wesen dor Giorimnungsvorghinge angestellt hat, su wenig sichere Wrfolge

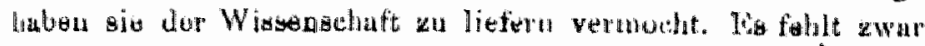
nijho an Theorien der versuchiodensinn Art, aber keine van

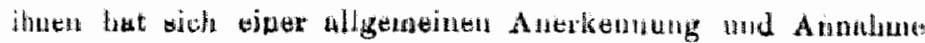

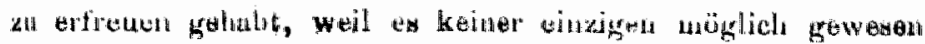

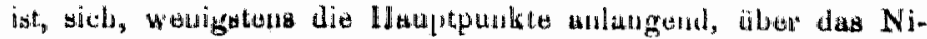

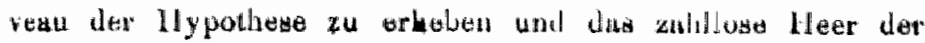

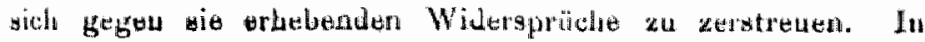

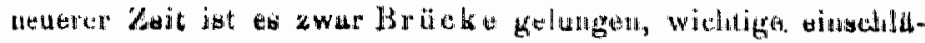
gige Thatsuchea zu equatatiren, aber diemelben hezieluen alch nur unf die negative Soite der lirage; wir erfislaren durch sie, whs die Geriaunng innerhulb des Körpens belindert, ohne freilich von der Natar der lesmanenden Krifite eine Ahoung zu bevitzen, aber wir erfaliren nicht, wodurch sie aueserhall, des Körpars beswirkt wird. Ilier sich bei der Angchanung beruhigen, dem prliexistirenden lidsteratolr inhürir nun einmal als urserüngliche Ligenschuft die lä̈ligkeit nnd dus Bestreben wus deun flüesigen Aggregatzustande spontan in den festen übersugelien, Liesen sich neuon Hypothesen in die Armo werfon. lis blies inner des Versuches werth, zu ermittoln, ob die lirugo nicht auch ilare positive Suite hat, ob es nicht aussorhulb dis liusecotoftee ein wirksumes l'rincip giebt, das soine Auabcheidung verursacht und wo dasselbe za suchen ist.

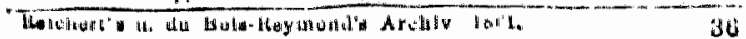

Afb. 9: Arch. Anat. und Physiol. 1861. Ausg. v. C.B. Reichert und E. du Bois-Reymond. 
rieën van Schmidt zijn vaak gecompliceerd en het is erg moeilijk om vanuit ons tegenwoordige standpunt zijn terminologie, juist te verklaren.

Zijn eerste onderzoekingen zijn practisch een duplicaat van het werk van Buchanan. Ook Schmidt bestudeert de invloed van bloedcomponenten op de stolling van hydrocele vloeistof. Hij komt tot de conclusie dat de stolling door witte bloedlichaampjes wordt veroorzaakt. De eigenlijke stollingsreactie ziet hij als een "chemische reactie tussen de fibrinogenestof en de fibrinoplastische stof". In het lichaam zou de stolling door ontleding van de fibrinogene en de fibrinoplastische stof, in statu nascendi verhinderd worden, een concept dat ons uit zijn publicaties niet geheel duidelijk tegemoet treedt.

In 1872 vindt Schmidt een derde stof, het fibrineferment. Hij verkreeg dit door extractie met alcohol uit serum. In droge vorm is het stabiel. $\mathrm{Na}$ oplossen beinvloedt het de reactiesnelheid van de bloedstolling en het is bij $37^{\circ}$ optimaal actief.

In het licht van hetgeen we nu weten moet het niet onmogelijk geacht worden dat hij op deze wijze inderdaad een geringe hoeveelheid actief thrombine isoleerde maar verder beweerde Schmidt dat aan de fibrinevorming het ontstaan van een oplosbare tussenstof voorafging, die dan door zouten welke zich in het plasma bevonden tot fibrine werd omgezet.

Zoals gezegd vindt Schmidt dat de leucocuten een bijzonder belangrijke rol bij de stolling spelen. Zij zouden als het bloed buiten de vaten treedt, kapot gaan en het fibrineferment en geheel of gedeeltelijk ook de fibrineplastische stof leveren. De grote hoeveelheid "granulen" die hij in een stolsel waarnam werden door hem gezien als afbrakproducten van de leucocyten, nu denken we eerder aan bloedplaatjes.

Schmidt bleef echter ook na de publicaties van Bizzozero (1882) en Hayem (1883) over de rol van de thrombocyten bij de bloedstolling, zijn standpunt trouw, dat leucocyten belangrijk waren. Hiji verdedigde dit met de volgende waarnemingen en argumenten:

1e Tijdens de stolling verdwijnt blijkbaar een groot deel der leucocyten. 
$2 \mathrm{e}$ In serum en in stolsel worden weinig leucocyten gevonden.

$3 \mathrm{e}$ in afgekoeld en gesedimenteerd paardenplasma, begint de stolling in de leucocytenlaag, terwijl het bovenstaande plasma en de zich eronderbevindende cellen eerst nog vloeibaar blijven.

$4 \mathrm{e}$ Door ontleding van de cellen komt fibrinoplastische stof vrij.

In de loop der jaren ondergaat de theorie van Schmidt verscheidene wijzigingen en in 1876 publiceert hij een samenvatting waarin hij de inmiddels vrij harde bewijzen van de enzymwerking van het fibrineferment met zijn oude opvattingen poogt te verzoenen. Volgens deze theorie moet het fibrineferment met de fibrinoplastische stof en fibrinogeen reageren. Dit werd fel bestreden, o.a. door Hammarsten.

Daarna volgen nog enige theorieën en veel polemieken, doch in 1892 werd de uiteindelijke theorie van Schmidt geformuleerd en gepostuleerd. Volgens zijn "Blutlehre" vindt de bloedstolling in twee fasen plaats. Het fibrineferment noemt Schmidt van toen af "thrombin" en hij postuleert tevens dat dit in het circulerende bloed voorkomt als "prothrombine", deze actieve stof zou door de leucocyten gevormd worden. Het is een vrij vage stelling en we moeten aan dit "prothrombine" beslist niet de status verbinden die het huidige prothrombine heeft. Ook bij het zorgvuldig nalezen van zijn werk kan men niet anders besluiten dan dat het fibrineferment in de ene proef thrombine, in de andere weefselthromboplastine of phospholipide geweest is.

Schmidt blijft aan de bloedcellen voor het ontstaan van de stolling grote waarde hechten. Zijn argumenten voor deze theorie waren-

1. De stolling gaat van de leucocytenlaag uit.

2. Transsudaten met veel cellen stollen altijd sneller dan die waarin zich weinig of geen cellen bevinden.

Het bloedplasma zou het protoplasma van de cellen ontleden, waardoor de "zymoplastische" met allcohol te extraheren stoffen vrijkomen. Bedoelde hij hiermede fosfolipiden? Deze zymoplastische stoffen zouden het thrombine activeren, maar 
daamaast bevatten de cellen, alles vig. Schmidt, een wateroplosbare stof, het "cytoglobin" dat de stolling remt.

Schmidt stond niet alleen met zijn theorieën over de fibrinevorming, maar ook met zijn mening over de roll van neutrale zouten bij het ontstaan van de bloedstolling, vaak tegenover de meningen van zijn tijdgenoten. Met niet aflatende energie trad Schmidt bijvoorbeeld op tegen hen die beweerden dat calciumzouten een belangrijke rol bij de bloedstolling speelden. Zoals wij in het volgende hoofdstuk zullen zien werd de vraag over de rol van het $\mathrm{Ca}^{++}$juist tegen het einde van Schmidt's loopbaan een belangrijk onderwerp. De situatie van Schmidt's opvattingen kan niet beter worden geschetst dan door Morawitz ${ }^{8}$ die in 1905 schrijft: "Het gedeeltelijk speculatieve karakter van de stollingstheorie van Schmidt, is er het gevolg van geweest dat zijn opvattingen geen verder gehoor hebben gevonden en dat speciaal zijn leer over het ontstaan van het fibrineferment niet verder is onderzocht".

Graag hadden wij, om achteraf enige klaarheid in de historische positie van Schmidt te brengen enkele van zijn cruciale experimenten herhaald. Bij het lezen van zijn proefbeschrijvingen stuit men echter geregeld op punten waar men, een beslissing in moet nemen over experimentele details die niet expliciet vermeld staan en dergelijke beslissingen blijken in het licht van wat wij nu weten voor de interpretatie van de proeven essentieel. In nog veel sterker mate dan bij Buchanan het geval was krijgt men de indruk dat nu eens thrombine, dan weer thromboplastine voor (versnelling van) de stolling verantwoordelijk geweest is, terwijl de auteur naar een overkoepelende verklaring blijft zoeken.

${ }^{8}$ Paul Morawitz werd op 3 april 1879 in St. Petersburg geboren, studeerde fysiologie in Göttingen en Straatsburg en geneeskunde in Tübingen en Heidelberg. Hij publiceerde veel over interne geneeskunde en bloedstolling. Hij stierf 1 juli 1946 . Hij werd vooral bekend door zijn publicatie in 1905 "Die Chemie der Blutgerinnung". 


\section{c. De opponenten van Alexander Schmidt}

Argumenten tegen de opvattingen van Schmidt kwamen o.a. van Hammarsten, Brücke, Bizzozero en Wooldridge.

Hammarsten 1878 was het met Schmidt eens dat de bloedstolling door fermentwerking plaatsvond, doch beweerde dat de "fibrinoplastische stof" bij de stolling geen rol speelde. Zijn experimenten toonden aan dat de fibrinevorming plaatsvond door veranderingen van de fibrinogene stof (fibrinogeen) en dat de twreede door Schmidt gepostuleerde stof hierbij niet nodig was. Een tweede punt dat Hammarsten corrigeerde was het mechanisme van de fibrinevorming. (men zie hierover vorige paragraaf). Ook de opvatting van schmidt, dat zouten nodig waren om een fibrine neerslag te verkrijgen kon Hammarsten weerleggen, want hij had met een fibrinogeen oplossing waarin zich geen zouten bevonden door toevoegen van eveneens zoutloze fermentoplossing, stolling verkregen. Hij viel Schmidt aan waar deze beweerde dat de stolling een chemische reactie van fibrinogene en fibrinoplastische stof was. Zoals we in de vorige paragraaf reeds zagen, zou in het lichaam de stolling verhinderd worden door ontleding van deze beide fibrinegeneratoren in statu nascendi. Brücke was dit niet met hem eens en hield vol dat de fibrinoplastische stof secundair aan het neergeslagen eiwit hechtte. Dit gold te meer, daar uit Schmidt's eigen proeven duidelijk gebleken was, dat het serum, als zodanig, beslist niet minder stolling induceerde dan de door hem geisoleerde stof, die als het een min of meer zuivere stof was, toch een veel sterker coagulerende werking zou moeten hebben. Achteraf moet men concluderen dat de heftige wetenschappelijke controverse over de aard van de voorloper(s) van het fibrine en de rol van enzymen daarbij verklaard kan worden doordat Schmidt twee situaties die uiteindelijk vaak niet van elkaar te onderscheiden waren wel met elkaar moest verwisselen. In $\min$ of meer zuivere fibrinogeenpreparaten, zoals sommige monsters hydrocelevloeistof of in de preparaten die Hammarsten bereidde konden sommige min of meer zuivere thrombinepreparaten of liever ieder preparaat dat zoals een oud 
stolsel mat een paar moleculen thrombine bevatten, op den duur stolling veroorzaken. Andere "fibrinefermentpreparaten" bestonden echter uit weefselthromboplastine en/of phopholipiden. Deze deden niets met fibrinogeenpreparaten als er niet een of ander preparaat bij gedaan werd dat de factoren II, V, $X$ en VII bevatte, zoals die b.v. uit serum kunnen worden bereid. (f. II en V zujn dan weliswaar in geringe hoeveelheid aanwezig maar ze zijn er wel). Bovendien werd men misleid doordat thrombine als het eenmaal ontstaan is door antithrombine werd weggevangen zodat de belangrijkste eigenschap van een katalisator, nl. na de reactie onveranderd teruggevonden te worden niet kon worden geverifieerd c.q. afwezig geacht werd. Bizzozero viel Schmidt aan op het stuk van de rol van de leucocyten in de bloedstolling. Op pag 301 van zijn publicatie in 1882 zegt hij :

Schmidt schrieb die grösste Wichtigkeit den farblosen Körperchen zu. Die Zerstörung derselben ist es, die nach seiner Ansicht das Ferment und theilweise oder insgesammt die fibrinoplastische Substanz liefert. Nun fragen wir uns, ob diese Zerstörung der farblosen Blutkörperchen beim Gerinnungsvorgange wirklich erwiesen sei? Da die Gerinnung auch in mikroskopischen Präparaten zu Stande kommt und binnen wenigen Minuten nach dem Austritte des Blutes aus den Gefässen erfolgt, so ist es klar, dass die Zerstörung der farblosen Blutkörperchen eben in jener Periode stattfinden müsste, so dass es ein Leichtes sein dürfte, sie wirklich unter dem Mikroskope vor sich gehen zu sehen. Indessen kann sich jedermann leicht überzeugen, dass sie eben nicht stattfindet.

Wenn man einen Finger ansticht, mit aller Eile das austretende Blut auf einem Deckgläschen auffängt, und dasselbe alsdann längere Zeit einer unausgesetzten Beobachtung unter dem Mikroskope unterwirft, so sieht man unter seinen Augen nicht ein einziges farbloses Blutkörperchen zerfallen.

Over de in het begin van de stolling optredende klontering van de thrombocyten, gaat hij op pag. 305 e.v. verder:

Nun kann ich nicht gerade behaupten, dass die von Alex. Schmidt gesehenen Körnchen den Körnchenbildungen anderer 
Autoren entsprachen. Wäre dies aber der Fall, so begreift man sehr wohl, wie wenig Gewicht die Beiden Gründe haben, welche er gegen die Theilnahme derselben an dem Gerinnungsworgange anführt. Er sagt, dass sie im frisch aus der Ader gelassenen und gekühlten Pferdeblute nicht vorhanden sind; und das ist ganz richtig; aber er hat übersehen, dass sie darin in Gestalt der Blutplätchen bestehen. Was aber die Reaktionen anbetrifft, so konnte Schmidt, da er die Blutplättchen nicht kannte, natürlich auch nicht ahnen, dass sie aus verschiedenen Substanzen zusammengesetzt sind; und es wäre wohl denkbar, dass jenes Residuum ihres Zerfalles, welches er als Körnchenmasse vor sich hatte und auf seine Reaktionen prüfte, nur den resistentesten Bestand theil dieser Gebilde darstellte.

Es ist wahrscheinlich, dass Schmidt ganz andere Schlüsse aus seinen Versuchen gezogen hätte, wenn ihm die Existenz der Blutplättchen bekannt gewesen wäre. Die Unbekanntschaft mit derselben musste ihn auf Irrwege verleiten; denn dass sich in allen Fällen, wo er es mit den weissen Blutkörperchen allein zu thun zu haben glaubte, um Gemenge dieser und der Blutplättchen (resp. der Alterationsprodukte der letzteren) handelt, so musste er, bei seiner Unbekanntschaft mit letzteren Elementen, offenbar der ersteren Alles das zuschretben, was ich, auf Grund meiner Versuche, zu deren Schilderung ich jetzt übergehe, den Blutplättchen zuzuweisen genöthigt bin.

Tenslotte willen we Leonard Charles Wooldridge (1891) noemen. Ook hij ageerde tegen Schmidt's theorie over de leucocyten. Zijn mening heeft echter niet veel bekendheid gekregen en weinig aanhangers gevonden. Hoezeer de opvattingen verdeeld waren schrijft Wooldridge in het "Report to the Scientific Committee of the Grocers' Company" in 1888, dat later in Leipzig, vertaald werd uitgegeven, als volgt:

Nach der gegenwärtig herrschenden Meinung (d.w.z. de mening van Schmidt) wird die Gerinnung des Blutes durch den Zerfall der weissen Blutkörperchen eingeleitet. Ein ernsthafter Widerspruch gegen diese Lehre wird nur insofern erhoben, als von manchen Forschern die gedachte Rolle nicht den weissen 
Körperchen, sondern einem besonderen Formelement zugeschrieben wird, den sogenannten Hämatoblasten oder Blutplattchen.

Die Urtheile der verschiedenen Beobachter über die Blutplättchen gehen weit auseinander. Einiger übertragen alle Eigenschaften, welche nach Alexander Schmidt den weissen Körperchen eigenthümlich sein sollen auf die Blutplättchen. (Bizzozero, Archives italiennes de Biologie T.I. und Centralbl.f.d.med. Wiss. 1882).

Andere sind wohl der Meinung, dass die Blutplättchen von Wichtigkeit sind bei gewissen Formen der Gerinnung innerhalb des Körpers, leugnen aber, dass sie irgend einen Einfluss haben auf die Gerinnung ausserhalb des Körpers. (Eberth und Schimmelbusch, Fortschritte der Medizin III. 1885. Virchow's Arch. 108, 1887).

Endlich wird behauptet, dass die Blutplättchen überhaupt keine Formelementen seien, sondern Niederschläge von Globulin (welche durch Fibrinferment leicht in Fibrin umgewandelt werden sollen), und dass sie bei der Gerinnung von gelassenem Blut ohne Bedeutung sind (Löwit, Wiener Sitzungsber. Bd. 89, III und Bd. 90, III (1884). Arch. F. exp. Path. Bd. 24, 1888).

Durch die Einführung der Blutplättchen in die Gerinnungslehre ist nur die Verantwortung von einem Formelement auf ein anderes übertragen worden. Dagegen ist man der Erörterung der biologisch wichtigen Frage nicht näher getreten, $o b$ das Plasma für sich allein gerinnen kann oder ob es der Mitwirkung von Zellen bedarf.

Over Schmidt's controverse met Arthus en Pagès over de rol van het $\mathrm{Ca}^{++}$komen wij in het volgende hoofdstuk terug.

Schmidt's tegenstanders namen zijn publicaties vaak te letterlijk. Ze konden ook niet anders. Hijzelf kende hun argumenten, doch liet zich hierdoor weinig beinvloedlen. Het gevolg daarvan was dat zijn pionierswerk door veel tijdgenoten werd onderschat. Alexander Schmidt was de eerste onderzoeker die probeerde het gehele gebied van het onderzoek over de bloedstolling niet alleen te overzien, doch ook te begrijpen. Als zodanig is hij een di- 
ZUR

\section{B L U'T L E H R E}

int

ALEXANDER SCHMTDT.

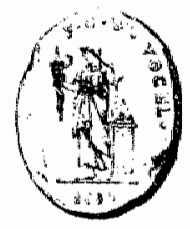

LEIL'ZIG,

VERLAG VON F.C. IV. VOGEL.

1892. 
recte voorganger van latere onderzoekers als Armand James Quick (1894-1978), Walter Seegers (geboren 1911) en Robert Gwyn Macfarlane (geboren 1907).

We hebben veel aandacht aan Schmidt besteed, niet alleen omdat de wetenschappelijke discussie over de bloedstolling in zijn tijd zich om zijn figuur uitkristalliseert, maar ook omdat hij de eerste is die het concept prothrombine aan de orde stelt.

Tevens echter hopen we te hebben laten zien dat dit concept, net zoals vele van zijn andere theorieën, zeer onduidelijk was en in geen enkel opzicht vergeleken mag worden met het concept van prothrombine als plasmaeiwit, dat het proenzym van prothrombine is.

Zoals we later zullen zien, is dit de unieke verdienste van Pekelharing. 


\section{DE ROL VAN HET CALCIUMION EN DE VERDERE ONTWIKKELING}

\section{a. Arthus en Pagès}

In 1888 deden de franse onderzoekers Arthus ${ }^{9}$ en Pagès ${ }^{10}$ te Parijs onderzoekingen over het stremmen van melk. $\mathrm{Zij}$ toonden aan dat voor de werking van het lebferment $\mathrm{Ca}++$ beslist noodzakelijk was. Tot deze conclusie kwamen zij doordat de reactie in aanwezigheid van $\mathrm{Ca}^{++}$bindende anionen als oxalaatfluoride of vetzuur geremd werd.

Zoals zovelen werden zij getroffen door de overeenkomst tussen bloedstolling en melkstremming en zij stelden zich de vraag of $\mathrm{Ca}$ ionen ook voor de bloedstolling noodzakelijk zijn.

9 Maurice Arthus werd op 9 januari 1862 in Angers, Maine et Loire geboren. Hij studeerde in Parijs en promoveerde in 1886. In 1890 werd hij Chef de conférences physiologie aan de Sorbonne, in 1896 professor in de fysiologie in Freiburg, in 1900 Chef de laboretoir aan het Instituut Pasteur in Lille, in 1903 professor aan de Ecole de Medecine in Marseille en in 1907 werd hij als professor in de fysiologie in Lausanne benoemd. Hij werkte geruime tijd samen met Calixte Pagès, Docteur de Medecine aan de Sorbonne.

Naast de bloedstolling werkte hij over enzymen, glycolyse, anaphylaxie, antitoxische sera en andere onderwerpen. Hij is het bekendst vanwege het "Arthus fenomeen", de anaphylaxe die door hem gelijktijdig met Pirquet en Schick, bij konijnen die met paardenserum behandeld waren, werd waargenomen. Hij overleed in 1945.

10 Clếment Calixte Pagès werd op 15 februari 1857 in Lacanal te Salvagnac (Tarn) in Frankrijk geboren. Hij promoveerde in 1888 
Indlerdaad bleek dat bloed, als het werd opgevangen, in een vat dat voldoende $\mathrm{Ca}^{++}$bindende stof bevatte, niet stolde.

Reeds lang kende men het z.g. "Salzblut", bloed opgevangen in $1 / 3$ volume verzadigde $\mathrm{MgSO}_{4}$ oplossing. Dit bloed stolde niet. Als men het echter verdunde, trad wel stolling op, waarschijnlijk omdat lage $\mathrm{SO}_{4}$ ionconcentratie voldoende $\mathrm{Ca}^{++}$ionen vrij laten om het stollingsproces mogelijk te maken. Bovendien zal een sterke $\mathrm{MgSO}_{4}$ oplossing verscheidene stollingsfactoren neerslaan en de polymerisatie van fibrinemonomeren beletten. $\mathrm{Na}$ verdunning van in oxalaat of fluoraat opgevangen bloed treedt geen stolling meer op, omdat de $\mathrm{Ca}$ ionen gebonden blijven. Toevoeging van voldoende $\mathrm{CaCl}_{2}$ doet altijd weer stolling ontstaan.

Arthus en Pagès interpreteerden hun experimenten a.h.v.

Ten 1e: Het bloed kan niet stollen als het geen calciumzouten bevat.

Ten 2e: Stoffen die het bloed décalcificeren zijn anticoagulantia. Oxalaten, fluoriden en alcalische zepen slaan geen fibrinogeen, paraglobuline en fibrineferment neer, maar werken doordat $\mathrm{zij} \mathrm{Ca}$ binden. Ook strontiumzouten kunnen stolling induceren, barium en magnesiumzouten niet.

Ten 3e: Het fibrine is een calciumverbinding. Het calciumatoom is een integrerend deel van het fibrinemolecuul. Het fibrinemolecuul is het Ca zout van het fibrinogeen.

Ten 4e: Het fibrineferment kan slechts op het fibrinogeen inwerken bij aanwezigheid van een calciumzout.

Met hun eerste conclusie kunnen we het nog steeds eens zijn en met hun tweede ook, all moet worden opgemerkt dat $\mathrm{Sr}$ en $\mathrm{Ba}$ te Parijs bij Prof. Dr. Ch. Richet op een proefschrift, getiteld: "Recherches sur la pexine".

In 1894 schreef hij voor de Faculté des Sciences, van Parijs, :"Physiologie de la matière minérale du lait", en hij ontving de Montyon prijs in 1896 voor zijn onderzoekingen op het gebied der experimentele fysiologie. 
jonen zich ook met de $\mathrm{Ca}^{\mathrm{TT}}$ bindende jonen kunnen binden en zodoende $\mathrm{Ca}^{++}$kunnen vrijmaken. Een direkt bewijs voor de deelname van $\mathrm{Sr}^{++}$en $\mathrm{Ba}^{++}$aan de stolling leveren de proeven van Arthus en Pagès niet. Zelfs het meest moderne onderzoek heeft het probleem van de mogelijkheid van vervanging van de $\mathrm{Ca}^{++}$ionen in de bloedstollingsreacties nog niet opgelost. Bij de derde conclusie en de vierde ziet men dat het belang van $\mathrm{Ca}^{++}$wordt overschat. Modern onderzoek leert dat het fibrinogeen wel degelijk $\mathrm{Ca}^{++}$bindingsplaatsen heeft en ook dat het onttrekken wan alle $\mathrm{Ca}^{++}$àan een fibrinogeen oplossing maakt dat thrombine slechter op het fibrinogeen inwerkt, maar men neemt toch niet meer aan dat $\mathrm{Ca}^{++}$voor de reactie tussen fibrinogeen en thrombine onontbeerlijk is.

De proef waarop Arthus en Pagès hun conclusie 3 baseren is, dat zij geen fibrinepreparaat kunnen maken waarin niet nog enig $\mathrm{Ca}^{++}$is aan te tonen. Brücke had dit eerder gevonden (1857) en Freund kon het bevestigen (1888). Tegenwoordig kan men alleen maar toegeven dat met het soort technieken dat hen ten dienste stond de conclusie of $\mathrm{Ca}^{++}$wel of niet een onderdeel van het fibrinogeenmolecuul is, simpelweg niet getrokken kan worden. Anderzijds was er in die tijd zo weinig bekend over de chemie van eiwitten - het zou tot 1902 duren voordat Hofmeister en Fischer vonden hoe een eiwitketen uit aminozuren was opgebouwd - dat men deze conclusie onmogelijk vergezocht kan noemen. Toch zou men verwacht hebben dat zij gevonden hadden ook geen fibrinogeenpreparaat te kunnen maken zonder $\mathrm{Ca}^{++}$hetgeen hun derde conclusie zo niet zou ondergraven, dan toch minder hecht gefundeerd gemaakt zou hebben. Men vermoedt dat ze bij deze aanname bewust of onbewust geleid werden door hun wens de conflicterende visies van Hammersten en Schmidt met elkaar te verzoenen. Woordelijk schrijven zij: "La formation de la fibrine exige l'intervention de trois substances, une substance fibrinogène, une substance fibrinoplastique, qui n'est pas de la paraglobuline, c'est un composé calcique, et un fibrinferment. (Het paraglobuline was de nadere chemische definitie die Schmidt voor de "Fibrinoplastische Substanz" gevonden had). 
Over de "substance fibrinoplastique" schrijven zij, (1890, pag. 744):

Al. Schmidt fait intervenir trois substances dans la formation de la fibrine; le fibrinogène, la substance fibrinoplastique et le fibrinferment. Hammarsten considère la substance fibrinoplastique comme inutile; le fibrinogène et le fibrinferment sont les agents nécessaires et suffisants de la coagulation.

Ces deux théories considérées comme irréductibles peuvent cependant être conclliêes si l'on tient compte des recherches exposées dans les nombreux mémoires de ces expérimentateurs, et de celles qui viennent d'être rapportées.

Si Al. Schmidt a besoin d'une substance fibrinoplastique, c'est que son fibrinogène et son fibrinferment ne renferment pas de sels de calcium, tandis que sa substance fibrinoplastique en contient.

Si Hammarsten n'a pas besoin de substance fibrinoplastique, c'est que son fibrinogène et surtout son fibrinferment renferment de sels de calcium. Sous l'influence du fibrinferment, et en présence des composées calcique solubles, le fibrinogène subit une transformation chimique sonnant lieu à la formation d'un composé calcique insoluble, la fibrine.

$\mathrm{Zij}$ vergelijken de fibrinevorming weer met kaasvorming:

Les sels de calcium jouent le rôle de substance caséoplastique pour le lait; de substance fibrinoplastique pour le sang.

De vierde conclusie is onjuist. Ook als er geen $\mathrm{Ca}^{++}$aanwezig is of als $\mathrm{Ca}^{++}$gebonden wordt door een sterke chelator zoals EDTA kan thrombine op fibrinogeen inwerken. Wel verandert het fibrinogeen onder die omstandigheden in een minder goed substraat en werkt thrombine minder effectief maar de reactie blijft mogelijk. Dit was al, voorzover de techniek het toeliet, geconcludeerd door Hammarsten in 1875. Uit het werk van Arthus en Pagès krijgt men niet de indruk dat de versnellende werking van $\mathrm{Ca}^{++}$op de thrombine-fibrinogeen reactie hen op een dwaalspoor geleid heeft. Eerder zijn zij, zoals we al meer zagen, misleid, doordat sommige "thrombine"-preparaten in wezen thromboplastines waren die uiteraard zonder $\mathrm{Ca}^{++}$niet stollingsbevorderend werken. 


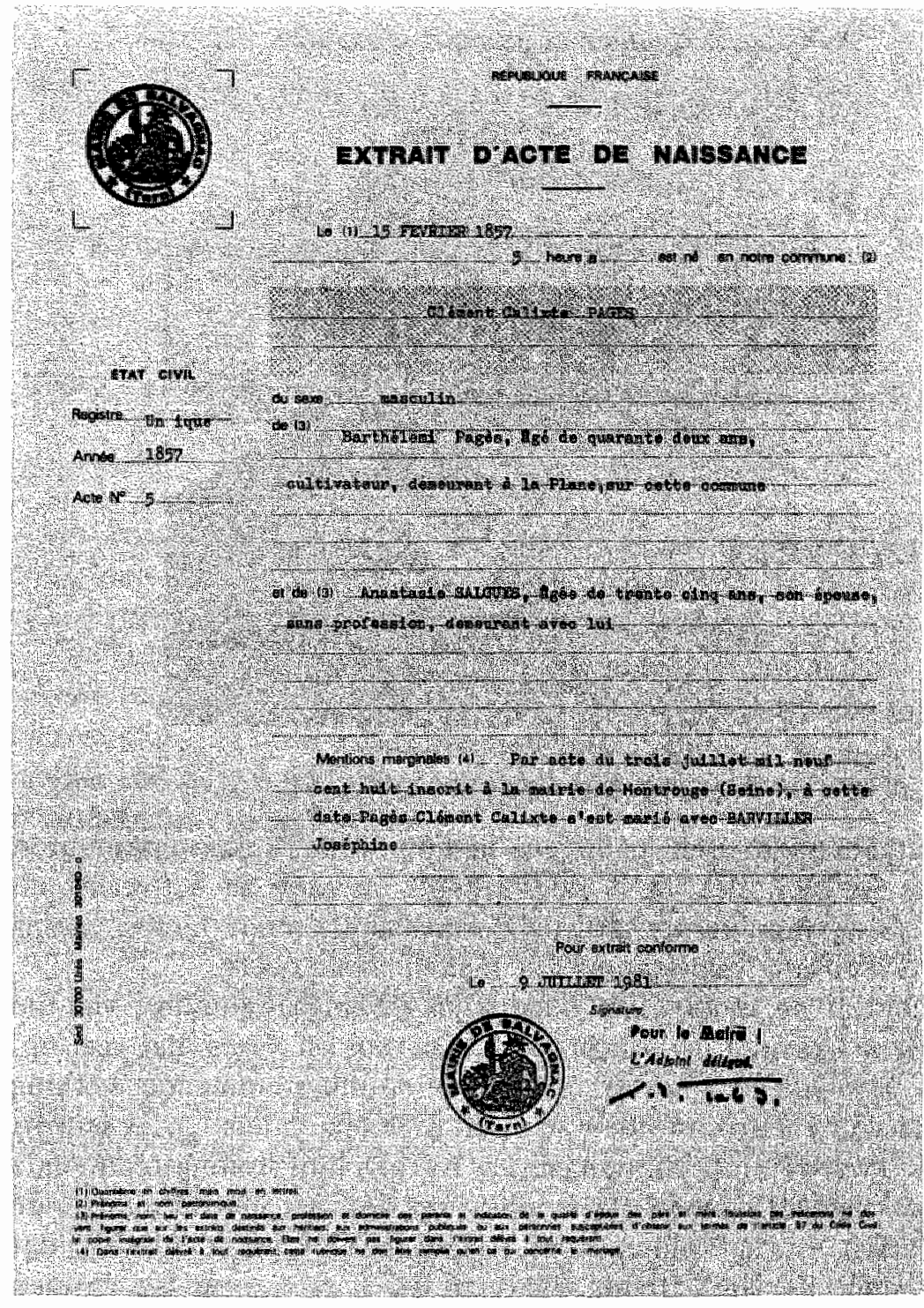

Afb. 11: Geboorte akte C.C. Pagès 
Afb. 12: Maurice Arthus (1862-1945)

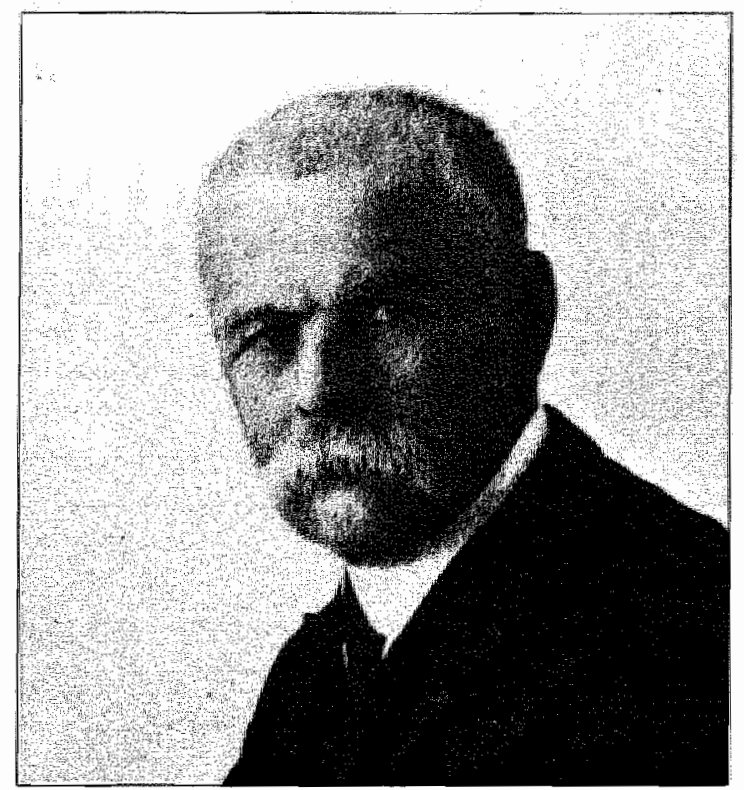

Nergens vindt men overigens in hun werk aanknopingspunten dat het feit dat $\mathrm{Ca}^{++}$noodzakelijk is voor de activering en werking van factor XIII, de fibrinestabiliserende factor, ergens iets met hun waarnemingen te maken gehad heeft.

Schmidt de grote maar omstreden stollingsdeskundige van die dagen had met de conclusies van Arthus en Pagès niet veel op. In zijn laatste werk erkend hif de stollingsremmende werking van oxalaat en fluoride - dat kan moeilijk anders - maar schrijft die in een elliptische redenering toe aan hun stollingsremmende werking. $\mathrm{Ca}^{++}$heft die werking op doordat het de remmende stoffen uit het bloed weer neerslaat. Ook wijst hij erop dat zouten als $\mathrm{Na}$ Citraat, die met $\mathrm{Ca}^{++}$geen neerslag vormen toch de stolling remmen. De $\mathrm{Ca}^{++}$bindendle werking van citraat was nog onbekend en de proef zou eerst door Pekelharing op de juiste wijze worden geinterpreteerd. 


\section{VI}

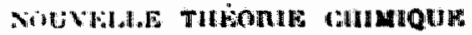

UE: I.A GOAGULATION DU SANG

Par MM.

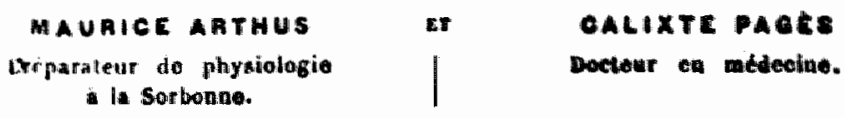

(Travail du laboratoire de phyeiologie do lo Sarbienne.)

lin raison des analogies thès grandes quo reprósentent dans leurs manilestitions extéricures la caséification du lait cl la coagrulation spontance du sang, nous avons été conduils a appliquer à l'úlude de ces doux phénomènes les mèmes moyens d'investigation. Nous avons précédemment indiqué les résultats que nous avons oblenus dans l'étude de la caséification du lait; nous allons exposer nos recherches sur la congulation du sang.

Les oxalates, Inorures et savons alcalins rendent lo sang non spontanément coagulable.

Nous avons recherché si les agents capables d'empécher ta cascification du lait rendent le sang non spontancment congulable. Nous avons à cet effet fait agir sur lo sang los oxalates et huorures alcalins.

2. Expdrience fondamontale du sang oxalatd. - On regoit dans 25 centimètres cubes d'une solution d'oxalaic de potas-

Afb. 13: Uit: Arch. Physiol. Norm. et Path. 22, (1890) 
Terecht merkt Schmidt op dat men $\mathrm{Ca}^{++}$vrij fibrinogeen met $\mathrm{Ca}^{++}$. vrij thrombine kan laten stollen, hetgeen Arthus ontkent. Toch lijkt het Schmidt te ontgaan dat deze opmerking hem wel staande houdt t.o.v. Arthus maar hem regelrecht in de armen van zijn andere tegenstander, Hammarsten, drijft. Waarschijnlijk ontging het hem trouwens niet helemaal. $\mathrm{Zijn}$ slotopmerkingen over deze materie hebben duidelijk het karakter van een achterhoedegevecht. Eigenlijk blijft men steken in de vraag die Green al in 1883 stelde: does the fibrineferment exist as a zymogen in plasma and is such zymogen converted into ferment by the action of $\mathrm{CaSO}_{4}$ ?

Zijn vraagstelling raakt de kern van de zaak, maar het gelukte hem niet hierop het juiste antwoord te vinden. Green's conclusie was: the action of the $\mathrm{CaSO}_{4}$ is connected in some way with the working of the ferment and not with its liberation or formation. Wat volgens onze moderne-opvattingen onjuist is. Green kwam tot de conclusie omdat in plasma waaraan een $\mathrm{MgSO}_{4}$ oplossing is toegevoegd de stolling door een $\mathrm{CaCl}_{2}$ oplossing plaatsvindt, zoals uiteraard te verwachten is op basis van het recalcificerings effect.

Ringer en Sainsburry (1890) voegden ook calciumsulfaat toe, volgens hen zouden ook strontium en bariumzouten deze werking vertonen. Freund (1888) stelt dat de bloedlichamen bij contact met een vreemde wand, dus een oppervlak anders dan de intacte vaatwand, alcalifosfaat afgeven, er zou dan met de kalkzouten uit het bloed, tricalciumfosfaat ontstaan, en hierdoor zou dan stolling optreden. Dit is in 1889 door Latschenberger en Strauch weerlegd.

Dat een vloeistof waarin zich fibrinogeen bevindt ook stollen kan als men geen calcium, doch thrombine toevoegt bewees Pekelharing in 1891 .

Pekelharing (1891) veronderstelde dat door het fibrineferment, dus thrombine, het calcium uit het plasma op het fibrinogeen kon inwerken, waardoor dit in vaste toestand overging. Schmidt bestreed zoals wij zagen niet alleen deze mening, doch ontkende tevens iedere deelname van calcium aan het stollingsproces. Het merkwaardige is dat men door herhaling van de proeven 
er nog steeds niet achter komt hoe de juiste toedracht van zaken is geweest bij het tot stand komen van de mening van de verschillende onderzoekers.

Als we gelijk hebben wanneer wij stellen dat wat men in die tijd thrombine noemde nu eens thrombine was en dan weer thromboplastine, dan verklaart dat wel alle geregistreerde proefresultaten, maar tegelijkertijd is onze hypothese niet falcificeerbaar. In practisch alle preparaten moet zowel thrombine als thromboplastine in wisselende verhoudingen voorhanden geweest zijn en subtiele, nergens beschreven variaties in de proeven moeten deze verhouding wezenlijk hebben kunnen beinvloeden. Omgekeerd is het gemakkelijk bij het reconstrueren van de oude proeven bewust of onbewust de reactiecondities zo te beinvloeden dat nu eens thrombine, dan weer thromboplastine de rol van "trigger" speelt .

Het enige houvast dat we hebben komt van de proeven die bewijzen dat een of andere reactiecomponent niet nodig is om een bepaald phenomeen te verklaren. Zo postuleerde Hammarsten in 1896 de juiste oplossing voor het probleem van de $\mathrm{Ca}^{++}$door te stellen dat dit niet nodig was om het fibrineferment met het fibrinogeen te doen reageren. Hij zegt (ibid. pag 395): Die specifische Einwirkung der Kalksalze auf die Gerinnung von Blut oder Plasma betrifft also nicht den chemischen Vorgang bei der Umwandlung des Fibrinogens. Es ist dagegen sehr wahrscheinlich, dass sie in naher Beziehung zu der Bildung des Fibrinfermentes steht. Die Beobachtung van PEKELHARING, dass in dem Blutplasma ein Stoff sich vorfindet, der selbst kein Fibrinferment ist, der aber nach Zusatz von Kalkzalz kräftig gerinnungserregend wirkt, ist nämlich leicht zu bestätigen.

Dat het calcium ion bij deze activatie een belangrijke rol speelt bewees Sabbatani (1902) zes jaar later, dan is echter het begrip prothrombine al gemeengoed en daardoor heeft Sabbatini een denkkader waarin hij de resultaten van zijn proeven kan plaatsen. Afgezien van de bijdrage van Pekelharing, waarop wij later uitgebreid terugkomen, willen we dit hoofdstuk besluiten met een zeer kort overzicht van de latere ontwikkelingen op het gebied van de bloedstolling. 


\section{b. De ontwikkeling na Schmidt}

Pas in 1904 stelde Morawitz dat alle voor de bloedstolling noodzakelijke stoffen zich in het bloed bevinden. Het fibrinogeen, het calcium en de prothombine zouden in het plasma voorkomen. De thrombokinase werd geleverd door de leucocyten als ze met een vreemd voorwerp, dus iets anders dan de intacte vaatwand, in aanraking kwamen. De leucocyten zouden hierbij ten gronde gaan. In hetzelfde jaar hadden Fuld en Spiro het "cytozym" beschreven, dit kwam overeen met het thrombokinase van Morawitz. Zij gaven deze naam "cytozym" in de jaren 1903-1904 toen zij over dit onderwerp werkten, maar alleen het "thrombikinase" van Morawitz heeft algemeen ingang gevonden. Deze theorie bleef tot 1909 gelden toen LeSourd en Pagniez bewezen dat het thrombokinase niet door de leucocyten, maar door de thrombocyten geleverd wordt. Freund had reeds in 1886 gezien dat contact met een vreemd oppervlak het stollingsgebeuren bespoedigde. Hij dacht dat adhaesieve krachten, die op de leucocyten werkten, er de oorzaak van waren dat dan stollingsstimulerende stoffen werden afgegeven. De gedachte die hieraan ten grondslag ligt is ook heden ten dage nog actueel, in zoverre dat de rol van de contactactivering van de stollingsfactoren en al of niet in samenwerking met thrombocyten of leucocyten nog steeds een open vraag is. Morawitz meent dat de werking die de weefselvloeistoffen op de bloedstolling uitoefenen aan hun gehalte aan thrombokinase is toe te schrijven. Dit zouden thermolabiele stoffen zijn die door alcohol worden neergeslagen.Volgens hem zou het thrombokinase, in het stromende bloed in uiterst geringe hoeveelheid aanwezig zijn. Het hierdoor gevormde thrombine wordt door de "antiautothrombines" ontleed en tevens zou een deel in "metathrombine" worden omgezet, welke stof bij de bloedstolling geen belangrijke rol speelt.

Bordet en Howell dachten hier in 1912 anders over en stelden dat thromboplastine juist thermostabiele en in alcohol oplosbare stoffen waren. Hun opvattingen hierover bleken later juist te zijn, in zoverre dat zij kennelijk op de rol van phos- 
pholiiden in de intrinsieke stolling wezen en Morawitz op de extrinsieke. Volgens Bordet zou er in plasma een "proserozym" voorkomen, dat in aanwezigheid van calcium en met cytozym samen, thrombine vormde, alles na activering door een vreemd oppervlak. In $1911 \mathrm{kwam}$ Howell met een theorie waarin hij beweerde dat de calcium ionen de feitelijke activator van het prothrombine waren. In het lichaam zijn ze onwerkzaam daar hier het prothrombine door het antithrombine gebonden is waardoor de calcium niet met het prothrombine kan reageren. Als het bloed buiten de vaten komt word het antithrombine door het thromboplastine geneutraliseerd, waarvoor eveneens calcium nodig zou zijn. Het prothrombine dat dan ontstaat wordt door calcium in thrombine omgezet. Later toen hij heparine had ontdekt, liet hij in zijn theorie het antithrombine vallen en stelde hiervoor heparine in de plaats. Hieruit ziet men duidelijk dat de "ontdekking" van het juiste mechanisme van de bloedstolling een min of meer arbitraire toekenning achteraf is, die wij ons kunnen veroorloven na driekwart eeuw maar die, ten tijde van de onderzoekers die ervoor verantwoordelijk zijn nog geheel onduidelijk is. In een cynische stemming kan men zich afvragen of er überhaupt enige verdienste in schuilt als een onderzoeker - zij het Hammarsten of Pekelharing - tastend in het duister tot de juiste conclusie komt. Howell, die uit zijn publicaties als een scherpzinnig man overkomt, kende hun werk en hun conclusies maar ziet daarin niet voldoende grond om niet met een radicaal verschillende theorie te komen. Degene die zich met historisch-natuurwetenschappelijk werk bezighoudt raakt op den duur doordrongen van de sterke relativiteit van het begrip ontdekking.

Zelden is een juiste waarneming aanleiding tot een steekhoudende conclusie, en als dat al gebeurt is er - behoudens het toeval - nauwelijks grond waarop die conclusie getrokken wordt en geen andere. De vaststelling van de meest waarschijnlijke gang van zaken geschiedt door de generatie na de eigenlijke onderzoekers die voor de vraagstelling verantwoordelijk waren. Tegelijkertijd met deze pessimistische versie wordt iemand in mijn positie sterk getrokken door de moed en de 
vasthoudendheid van de onderzoekers waarvan hij de werken bestureert. Veel belangrijker dan de juistheid van hun conclusies is de gedrevenheid waarmee ze doorgaan te onderzoeken, geleid door de hoop licht te zien in een probleem dat zo ondoorzichtig is dat het nog generaties zal duren voordat de "juiste" oplossing als het ware vanzelf door het uitslijten van de strijdpunten, gemeengoed wordt. We zullen dit in het hoofdstuk over Pekelharing en het prothrombine nog eenmaal zien. Ons verdere relaas dat handelt over het onderzoek naar de aard van het thromboplastine in een tijd dat iedereen het bestaan van "prothrombine" min of meer accepteert is dan ook noodzakelijkerwijze weer een weergave van werwarring.

Fuld en Spiro en Morawitz (1904) toonden tezamen aan dat toevoegen van weefselextract aan een gezuiverde fibrinogeenoplossing in tegenwoordigheid wan calcium geen stolling teweegbrengt.

Afhankelijk van de wijze waarop het gemaakt wordt en de manier waarop men veronderstelde dat het zou werken, zijn aan de weefselfactor diverse namen gegeven. Door Schmidt 18931895: zymoplastische Substanz; Morawitz 1904-1905: thrombokinase; Bordet en ook Fuld en Spiro, 1912-1913: cytozyme; Nolf, 1913: thromboplastine (thromboplastic substance); Howell, 1913: cephalin protein compound en cytozymphosphatid.

De uiteenlopende opvattingen van deze onderzoekers, komen neer op het verschil van inzicht over de werking van de thromboplastische stoffen. We kunnen daarin de "klassieke" opvatting onderscheiden waarvan het essentiele is dat prothrombine enzymatisch door "thrombokinase" in thrombine werd omgezet. De onderzoekers van deze groep waren het in vele opzichten met elkaar oneens, één opvatting echter hadden ze allen gemeen, n.l. dat de bloedstolling door de werking van enzymen tot stand kwam. Ze waren aanhangers van de enzymtheorie. Deze stroming wordt, rond 1910 doorkruist door een tweede groep onderzoekers waarvan we alleen Nolf en Hekma zullen noemen die iedere enzymwerking van bloedstollingsfactoren ontkenden en die we met Howell als de "non thrombin group" aanduiden. 
Deze onderzoekers verklaarden de bloedstolling door aan te nemen dat er in het plasma drie colloidale stoffen voorkwamen, die, onder bepaalde omstandigheden, samen het fibrine vormen.

Fibrinogeen en thrombogeen zijn het die in de opvattingen van de non-thrombin group in de lever worden gemaakt, de derde, het z.g. thrombozym, een proteolytisch enzym, wordt geleverd door de thrombocyten en leucocyten benevens de endotheelcellen van lymph en bloedvaten. Men onderkent weliswaar het bestaan van thrombine, maar beschrijft het als een mengsel van thrombozym, thrombogeen en fibrinogeen. $\mathrm{Zij}$ zien het als een oplosbare vorm van fibrine en beschouwen het als het resultaat van de stolling en niet als de oorzaak daarvan. In wezen dus een opleving van de eerste theorieën van Schmidt en nog vroegere onderzoekers.

Men ziet hier duidelijk dat speculatieve theorieën over het stollingsgebeuren tot rond 1910 voorkwamen, ofschoon de experimenten die er tegen pleiten al lang bekend zijn. Ze zijn door de latere onderzoekers niet overgenomen en eerst dat proces, de zeef der geschiedenis stelt vast wie er gelijk heeft. In dit verband willen we vooral Edgar Wölisch (1929) noemen. Hij was professor te Würzburg. Als fysioloog werkte hij van 1920-1940 over de bloedstolling, zodat zijn productieve periode, buiten het gestelde in dit overzicht valt. Dat we hem toch noemen vindt zijn oorzaak in het grote aandeel dat hij heeft gehad in het, op exacte wijze naar voren brengen van argumenten, die voor de enzymtheorie pleiten, zoals die o.a. uit het werk van Pekelharing gedestillerd konden worden. Zodoende heeft hij de aandacht van de toenmalige onderzoekers op deze theorie gevestigd. Dit heeft de ontwikkeling van denkbeelden over de eerste phase van het mechanisme van de bloedstolling zijn uiteindelijk beslag gegeven. Afgezien van verspreid werk over de antihemofiliefactoren (b.v. van Creveld) kan men zonder overdrijving zeggen dat het moderne onderzoek naar het moleculaire mechanisme van de bloedstolling begint met Owrens ontdekking van de factor $\mathrm{V}$ in de laatste jaren van de tweede wereldoorlog in Oslo. Van daar tot de huidige inzichten 
zoals die in Appendix A beschreven zijn gaat een lange weg die aanmerkelijk beter gedocumenteerd en minder verwarrend is dan de eerste phase van het moderne stollingsonderzoek waarop wij ons geconcentreerd hebben, maar waarin men ook steeds meer ziet hoe de geschiedenis de ontdekker maakt. Hoe verward de situatie bleef blijkt echter uit de werken van de belangrijke Amerikaanse onderzoeker Seegers, die tot in de jaren zeventig het woord prothrombine nog gebruikt voor een mengsel van de verwante factoren II, VII, IX en X.

Met de zuivering van prothrombine en de ontrafeling van zijn activeringsmechanisme in het begin van de jaren zeventig, werd aan deze verwarring een einde gemaakt. 


\section{PEKELHARING EN HET PROTHROMBINE}

\section{a. De persoon Pekelharing}

Min of meer kunstmatig hebben we tot nu toe een nadere beschrijving van het werk van Pekelharing laten rusten. De belangrijkste reden daarvoor is dat wij tot de overtuiging zijn gekomen dat Pekelharing zonder enige twijfel kan worden aangemerkt als de ontdekker van het prothrombine. Gezien het feit dat dat op het ogenblik onder de specialisten op het gebied van de bloedstolling beslist niet bekend geacht moet worden (zie b.v. Beck, Macfarlane, Owen etc.) willen we dat voor de Nederlandse wetenschap niet onaardige feit graag in een laatste hoofdstuk nader uit de doeken doen. Achteraf heeft dat misschien nog een ongewild realistisch effect. De lezer heeft kennis gemaakt met de grote onderzoekers van het eind van de vorige eeuw en heeft een gegrond vermoeden dat Pekelharing daar "eigenlijk" bij hoort. Wat hij precies gedaan heeft is echter nog niet geheel duidelijk, evenmin als het feit of hij nu eigenlijk een ontdekking van gewicht gedaan heeft, althans als men niet zonder meer op ons woord afgaat. Hiermee beschikt de lezer dan over ongeveer net zo veel informatie als de geinteresseerde buitenlandse onderzoeker tegen het eind van de vo- 


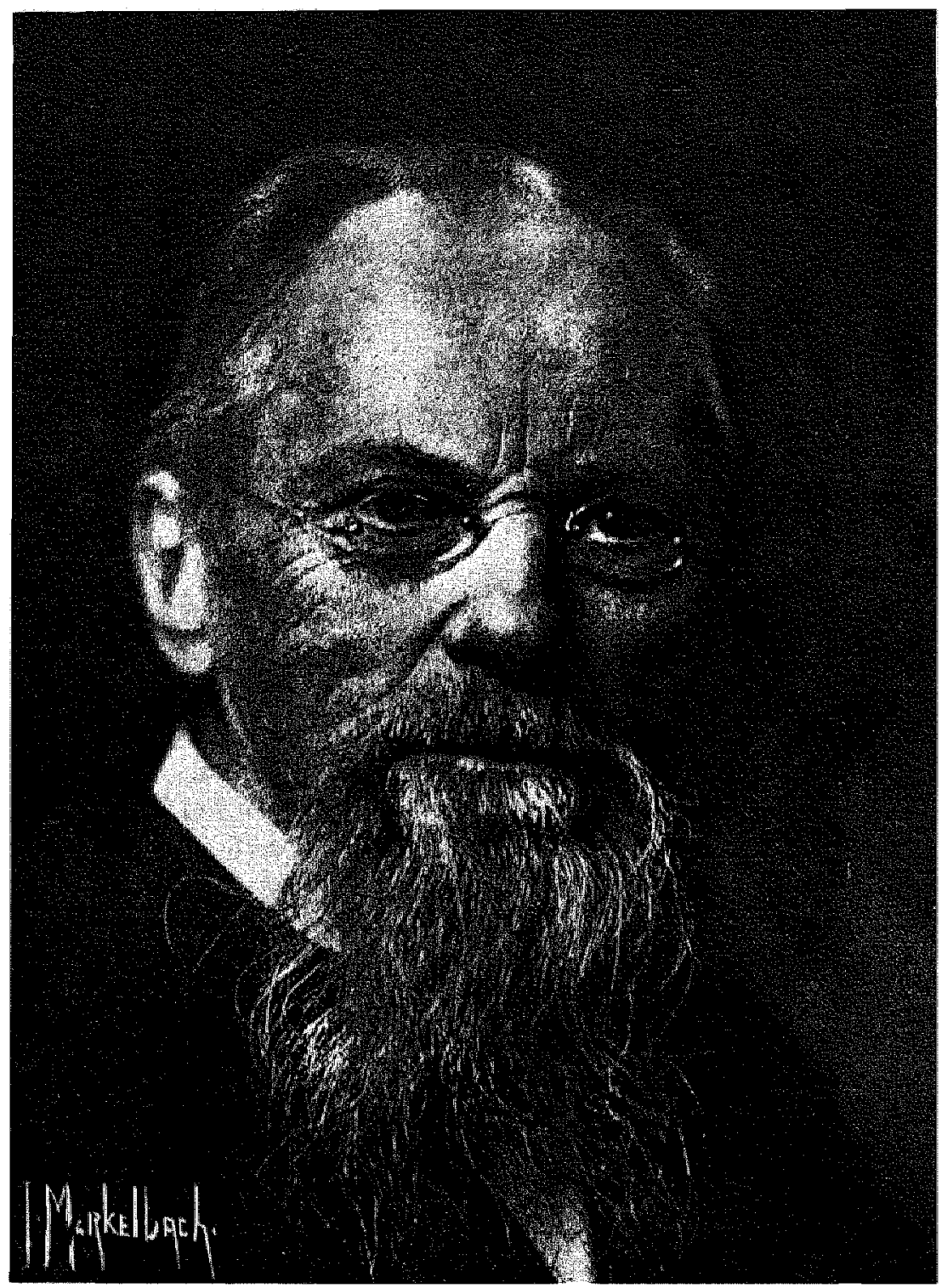

Afb. 14: Cornelis Adrianus Pekelharing (1848-1922) 
rige eeuw. In tegenstelling tot een Donders of misschien een Mulder, was het van Pekelharing niet zonder meer duidelijk dat het een geleerde van internationaal niveau was. Dit merkwaardige feit, dat men achteraf graag zou verdoezelen dringt zich toch onweerstaanbaar op als men zich in deze materie verdiept.

Wel is het waar dat hij werd uitgenodigd te schrijven in het "Festschrift" van Virchow, en dat hij zijn bescheiden rol op internationale congressen en in internationale gezelschappen had, maar toch werd hij voornamelijk als een nationale figuur gewaardeerd, zowel in het binnen- als het buitenland. Tot op de dag van vandaag heeft zijn erkenning daaronder te lijden. De oorzaak hiervan ligt waarschijnlijk in de eerste plaats in het beeld dat Pekelharing van zichzelf had. Uit zijn levensbeschrijving (zie volgende hoofdstuk) ziet men duidelijk dat hij voor zichzelf in de eerste plaats een taak zag binnen zijn eigen universiteit, zijn eigen maatschappij voor geneeskunst, zijn eigen land (met koloniën, dat wel).

Dit komt al heel duidelijk naar voren in zijn publikatiegewoonten. In tegenstelling tot b.v. Einthoven, die er zorg voor droeg al zijn belangrijke werk zowel in het Duits, het Frans als het Nederlands te publiceren beperkte Pekelharing zich voornamelijk tot een nationaal, ja lokaal en instituut gebonden medium. Zij het dat dit medium door de wereldnaam van Donders een duidelijk prestige had, het blijft toch te vergelijken met iets als de huidige "Mayo Clinics Proceedings" en had, door de taalbarrière zowel als door het feit dat nationalistische gevoelens in die tijd meer dan tegenwoordig in de wetenschap doorklonken waarschijnlijk een geringere slagkracht (zie tabel II). Het werk van Pekelharing gedaan in het Physiologisch Laboratorium te Utrecht, in de jaren 1881-1918 en daaronder valt al zijn werk van de bloedstolling, is voornamelijk gepubliceerd in "Onderzoekingen, gedaan in het Physiologisch Laboratorium der Utrechtsche Hoogeschool". De eerste en tweede reeks, resp. over de jaren 1848-1856 en 1857-1870 werden uitgegeven door F.C. Donders, de derde van $1872-1889$ door F.C. Donders en Th.W. Engelmann, de vierde van 1891-1897 door 
Th.W. Engelmann en C.A. Pekelharing en de vijfde reeks door C.A. Pekelharing en H. Zwaardemaker, over de jaren 1897 1918 en verder.

Uitgezonderd het door J.M. Baart de la Faille, H.G.K. Westenbrink en $P$. Nieuwenhuijse geschreven "Leven en werken van Cornelis Adrianus Pekelharing 1848-1922", dat in Utrecht bij N.V. Oosthoek's Uitgevers Mij in 1948, vijfentwintig jaren na zijn dood en juist een eeuw na zijn geboorte, verscheen, is hierover nooit meer iets gepubliceerd. De bovengenoemde schrijvers zeggen in hun voorwoord o.a.:

C.A. Pekelharing is in zijn tijd een markante figuur geweest in Nederland. Het is hem gegaan zoals zovele voortreffelijke mannen in ons land. Hun worden bij het terugtreden uit het ambtelijk leven en dan nog eens bij het overlijden, veel redevoeringen en tijdschriftartikelen gewijd. Maar speodig daarna wordt het stil om hun persoonlijkheid. Een enkele anecdote blijft nog de ronde doen, maar de herinnering vervaagt. Jongeren die hun plaatsen hebben ingenomen trekken ook de belangstelling tot zich en na enkele tientallen jaren zijn hun voorgangers legendarische persoonlijkheden geworden. Men weet niet meer hoe ze hebben gewerkt aan het tot stand komen van onze wetenschappelijke inzichten, hoe ze hebben meegebouwd aan de ontwikkeling van de maatschappij.

Geheel terzijde van de ontdekking van het prothrombine willen we toch meteen Pekelharings rol noemen bij de ontdekking van het vitamine B. Ook in dit verband wordt zijn naam nooit genoemd. Dat is in zoverre terecht als hij inderdaad bij zijn eigen werk over de beri-beri is blijven vasthouden aan een bacteriologische oorzaak van deze ziekte. Wel echter schiep hij in Nederlands Indië de directe omstandigheden die het onderzoek van Eijkman mogelijk maakte en bevorderde hij vanuit Nederland een blijvende steun aan diens onderzoek. Men zie hiervoor verder het volgende hoofdstuk. 


\section{TABEL II}

\section{BIBLIOGRAFIE VAN PEKELHARING}

Uitgesplitst naar plaats van publikatie

\begin{tabular}{|c|c|c|c|}
\hline \multicolumn{3}{|c|}{ Monografieën, losse lezingen etc. } & 18 \\
\hline \multicolumn{3}{|c|}{ Nederlandse tijdschriften } & 199 \\
\hline \multirow[t]{6}{*}{ waarvan: } & Ned. Tijdschr. v. Geneeskunde & 33 & \\
\hline & Kon. Ned. Acad. v. Wetenschap & 19 & \\
\hline & "Onderzoekingen" & 30 & \\
\hline & $\begin{array}{l}\text { Overige natuurwetenschappelijke } \\
\text { tijdschriften }\end{array}$ & 20 & \\
\hline & $\begin{array}{l}\text { Niet natuurwetenschappelijke } \\
\text { tijdschriften }\end{array}$ & 3 & \\
\hline & Kongresverslagen & 4 & \\
\hline \multicolumn{3}{|c|}{ Duitse vaktijdschriften } & 31 \\
\hline \multicolumn{3}{|c|}{ Buitenlandse congresverslagen } & 3 \\
\hline \multicolumn{3}{|c|}{$\begin{array}{l}\text { Dissertaties bewerkt onder zijn leiding } \\
\text { (allen in het Nederlands) }\end{array}$} & 26 \\
\hline
\end{tabular}




\section{b. De ontdekking van het prothrombine}

Maar nu nader ter zake over de ontdekking van het prothrombine door Pekelharing. Wij herinneren ons dat Arthus en Pagès de fibrinevorming vergelijken met het ontstaan van kaas. Toch waren ze zich bewust van verschillen. Zij zeggen: Lebferment kan ook bij afwezigheid wan kalkzouten het caseine veranderen en geschikt maken om calciumzouten op te nemen, doch fibrineferment kan alleen op fibrinogeen inwerken bij aanwezigheid van calciumzouten. Volgens hen zou bloed waaraan calciumoxalaat is toegevoegd vloeibaar blijven, omdat het ferment bij afwezigheid van calciumzouten het fibrinogeen niet kan omzetten. Pekelharing merkte hierover op (Onderzoekingen enz., 4e reeks I. p. 77-118): Men kan er zich echter van overtuigen dat in het axalaatplasma geen ferment voorkomt. Wordt het vermengd met $10 x$ verdund $\mathrm{MgSO}_{4}$ plasma dat door toevoeging van ferment volkomen, maar spontaan niet stolt, dan blifft ieder spoor van stolling uit.

Hier is Pekelharing het prothrombine al op het spoor als hij vervolgt: Men is het er bovendien over eens dat magnesiumsulfaatplasma dat ook na sterke verdunning en bij verwarming op een temp. van $30-40^{\circ} \mathrm{C}$ niet stolt, geen ferment bevat en ook dit plasma stolt, zoals Green het eerst aantoonde door toevoeging van $\mathrm{CaSO}_{4}$.

Later vonden Ringer en Sainsbury (Journ. of Phys. Vol XV 1890 p. 369) dat dit resultaat evenzeer door een oplossing van $\mathrm{CaCk}_{2}$, ja zelfs, ofschoon niet zo gemakkelijk, door een oplossing van barium of strontiumchloride verkregen kan worden. Slechts is het nodig, om met zekerheid stolling te verkrijgen, het $\mathrm{MgSO}_{4}$ plasma sterk, nl. 15 à 20 maal te verdunnen en weinig van het kalkzout toe te voegen, b.v. op $10 \mathrm{ml}$ verdund plasma 2 druppels van een $1 \% \mathrm{Cacl}_{2}$ oplossing. / Het gelukte Green niet alleen enkel $\mathrm{MgSO}_{4}$ plasma, maar ook paardenbloed dat door inspuiting van pepton bij het levende dier door afkoeling of door vermenging met een aftreksel van bloedzuigers verhinderd werd te stollen door toevoeging van $\mathrm{CaSO}_{4}$ tot stolling te brengen, zonder dat het nodig was daarbij van 
een oplossing van ferment gebruik te maken. Wij zetten onze vraagtekens bij deze proeven, maar vonden ook in het werk van Green niet voldoende aanleiding om een hypothese op te bouwen die verklaart waarom b.v. toevoeging van Catt ionen de werking van hiruddine teniet doen. In Greens tijd was de vraagstelling nog diffuser/Zou de werking van z.g. fibrineferment eenvoudig op die van een opgelost anorganisch kalkzout neerkomen? Deze vraag moest terstond ontkennend beantwoord worden. Want Green vond dat een naar de door Hammarsten aangegeven methode bereide zuivere oplossing van fibrinogeen door $\mathrm{CaSO}_{4}$, zonder de hulp van ferment, niet tot stolling gebracht kan worden. Zijn dus naast fibrinogeen, de overige bestanddelen van het bloedplasma in de oplossing aanwezig, dan brengt de toevoeging van gips stolling teweeg, maar de vermenging van fibrinogeen en gips alleen leidt niet tot de vorming van fibrine.

De essentie van het bovenstaande werd samengevat in de vraag die Green stelde in $1887 \mathrm{nl}$ : Does the fibrinferment exist as a zymogen in plasma? And is such zymogen conversed into ferment by the action of $\mathrm{CaSO}_{4}$ ? (Journ. of Phys. Vol. 8 1887 p. 366). Green heeft getracht hierop een antwoord te vinden. In de onderstelling dat dit zymogen, zo het bestond, in het stromend bloed aanwezig zou moeten zijn, werd paardenbloed dat door afkoeling verhinderd was te stollen, met een overmaat van alcohol behandeld. Het precipitaat, enige weken onder alcohol bewaard werd gedroogd en met $0,6 \% \mathrm{NaCl}$ uitgetrokken. Het extract, met $\mathrm{CaSO}_{4}$ bij $40^{\circ} \mathrm{C}$ gedigereerd, vertoonde niet de minste fermentwerking. Het is hem niet gelukt een eenduidig antwoord te vinden maar hij kwam wel tot een besluit: the action of the $\mathrm{CaSO}_{4}$ is connected in some way with the working of the ferment and not with its leberation or formation.

Zeker was het niet onmogelijk dat een stof uit het plasma met een $\mathrm{Ca}$ zout een ferment zou kunnen vormen. De bewerking met alcohol zou bepaalde reacties kunnen vertragen of zelfs onmogelijk maken. Dit geldt zowel voor de fermentwerking als voor de enzymvorming. Men moet besluiten, en leest dat 
ook tussen de regels van Greens stuk dat een eenduidige conclusie uit zijn proeven niet goed mogelijk was. De door Green zo precies geformuleerde vraag werd slechts korte tijd later door Pekelharing op schitterende wijze beantwoord. Hiervoor kunnen wij des te meer bewondering hebben als wij zien hoe Green slechts enkele jaren eerder toch aan de oplossing niet toekomt. Wij laten Pekelharing hierover zelf aan het woord. (Onderzoekingen, enz. 4e reeks I. p. 87).

Inderdaad ben $i k$, door bij het onderzoek een enigszins andere weg in te slaan, tot een bevestigend antwoord op de bovengestelde vraag gekomen.

Dit wil dus zeggen dat Pekelharing zich er geheel bewust van is het prothrombine te hebben gevonden. Hij vervolgt dan: Ik gebruikte het bloed van een rund, van het kalf, van de hond en wan het varken. Het uit de vaten stromende bloed werd, onder goed schudden, opgevangen in een verzadigde oplossing van $\mathrm{MgSO}_{4}$ (1 vol.opl. en 3 vol. bloed) of in een $1 \%$ opl. van kaliumoxalaat (1 vol. opl. en 9 vol. bloed). Met behulp van den centrifugaaltoestel werd het plasma van de bloedlichaampjes bevrijd. Door toevoeging van $\mathrm{CaSO}_{4}$ of $\mathrm{CaCl}_{2}$ kon het plasma steeds tot stolling gebracht worden, het magnesiumsufaatplasma na, het oxalaatplasma zonder verdunning. In geen geval heb ik spontaan stollen van het plasma, ook niet na sterke verdunning met water, waargenomen. Het oxalaatplasma bevatte altijd een overmaat van kaliumoxalaat. Toevoeging van een kalkzout bracht in het heldere" plasma een precipitaat van calciumoxalaat teweeg. In verband daarmede werd door zeer geringe hoeveelheden van een kalkzout daarin geen stolling veroorzaakt. Eerst wanneer er meer wan het kalkzout werd toegevoegd dan nodig was om al het oxaalzuur neer te slaan, kwam de stolling tot stand. Het heldere of nagenoeg heldere plasma (NB ongestold) werd met een verzadigde oplossing van $\mathrm{NaCl}$ vermengd, $\mathrm{MgSO}_{4}$ plasma met een gelijk volume, oxalaatplasma gewoonlijk met twee volumes. De fibrinogene stof werd dan door centrifugeren afgescheiden. Wanneer de vermenging wan het plasma met de keukenzoutoplossing voorzichtig geschiedt, zodat het ontstaan van schuim mogelijk ver- 
meden wordt dan zet zich in den centrifugaaltoestel het fibrinogeen gewoonlijk snel en volkomen op de bodem wan het vat, als een geleiachtige massa af. De daarbovenstaande heldere vloeistof kan gemakkelijk, zonder noemenswaard verlies van fibrinogeen afgegoten worden. Soms echter verzamelt zich het fibrinogeen voor een deel op de bodem en voor een deel aan de oppervlakte van de vloeistof, terwijl een geleiachtige streng beide delen met elkaar verbindt. Ook dan echter is de samenhang van het precipitaat groot genoeg om, bij enige voorzichtigheid, het afschenken van de vloeistof mogelijk te maken zonder dat meer dan enkele vlokken fibrinogeen verloren gaan. $O p$ deze wijze gaat naar mijn ondervindeing de afscheiding van de fibrinogene stof gemakkelijk en sneller en met minder verlies van materiaal dan door filtratie en dan op de andere door Hammersten aangegeven wije, waarbij men door omroeren de vlokken zich aan de oppervlakte doet ophopen en dan de daaronderstaande vloeistof met de hevel verwijderd.

Met behulp van het nog daaraanhangende zout werd het fibrinogeen in gedestillerd water opgelost. Bijna nooit loste het volkomen op, maar waanneer de vloeistof niet langer dan een uur gecentrifugeerd was en dus het fibrinogeen niet te lang met de sterke zoutoplossing in aanraking was gebleven, was het hierdoor geleden verlies aan materiaal niet belangrijk.

De oplossing was altijd enigermate geel van kleur en kon bij een temperatuur van $30-35^{\circ} \mathrm{C}$ door toevoeging van $\mathrm{CaSO}_{4}$ of $\mathrm{CaCl}_{2}$ tot stolling gebracht worden. Uit deze oplossing (ongestold) werd het fibrinogeen weer door vermenging met een glijk volume $\mathrm{NaCl}$ nnergeslagen en door centrifugeren afgescheiden. Dit precipitaat was wit van kleur en uit de oplossing daarvan met water werd, somtijds, maar dikwijls ook niet, door $\mathrm{CaSO}_{4}$ of $\mathrm{CaCl}_{2}$ de vorming van fibrine verkregen. Wanneer uit deze oplossing nog éênmaal het fibrinogeen door $\mathrm{NaCl}$ werd afgescheiden, dan werd steeds, evenzeer uit oxalaat als uit $\mathrm{MgSo}_{4}$ plasma, een stof verkregen die in alle opzichten de eigenschap vertoonde die door Hammarsten als de kenmerken van zuiver fibrinogeen beschreven zijn. De oplossingen van deze stof stolden nooit, ook na 2 maal 24 uur of langer, na 
toevoeging van $\mathrm{CaSO}_{4}$ of $\mathrm{CaCl}_{2}$ alleen.

Tot zover de door hem toegepaste methode.

Nu volgt zijn belangrijke conchusie:

Wanneer dus het plasma met de keukenzoutoplossing was vermengd moest deze stof wel voor een deel met de fibrinogene stof neergeslagen, maar poor een ander deel nog in het filtraat aanwezig zijn. Zij bleek dan daarin ook werkelijk te vinden te zijn. Wanneer het van het fibrinogeen afgeschonken plasma gefiltreerd en door dialyse arm aan zout gemaakt werd, dan bracht het, met behulp van $\mathrm{CaCl}_{2}$ of $\mathrm{CaSO}_{4}$, stolling van een zuivere oplossing van fibrinogeen, waarop het, alleen, geen merkbare werking had, teweeg.

Door langdurige dialyse werd de werkzame stof voor een deel, maar niet geheel neergeslagen: Hier volgt een voorbeeld:

Magnesiumsulfaatplasma van runderbloed, door $\mathrm{NaCl}$ van fibrinogeen bevrijd wrdt gefiltreerd en 65 uren gedialyseerd. Een deel van de inhoud van de dialysator wordt gefiltreerd. Daama worden gelijke hoevelheden van een zuivere oplossing van fibrinogeen vermengd met gelijke hoeveelheden van

a. de troebele dialysator inhoud . . . . . stolt niet

b. de troebele dialysator inhoud ...........

c. de gefiltreerde dialy sator inhoud. . . stolt niet

d. de gefiltreerde dialysatorinhoud . . . CaCl 2 stolt na 150 min. Ook voor verzadigen met $\mathrm{NaCl}$ wordt het "zymogen" niet geheel neergeslagen. Magnesiumsulfaatplasma werd met $\mathrm{NaCl}$ gesatureerd. Het heldere filtraat was na 21 uur gedialyseerd te zijn, nog helder gebleven. Gelijke delen hiervan werden vermengd met gelijke delen van een zuivere fibrinogeenoplossing a. met $\mathrm{CaCl}_{2}$ stolt na $65 \mathrm{~min}$.

b. zonder $\mathrm{CaCl}_{2}$ stolt niet.

Wanneer echter $\mathrm{MgSO}_{4}$ - of oxalaatplasma met $\mathrm{MgSO}_{4}$ verzadigd wordt, dan is het filtraat niet meer bij machte, ook na langdurige dialyse en bij aanwezigheid van kalkzouten enige stolling te veroorzaken. Alle werkzame stof wordt dan in de geprecipiteerde globuline gevonden. Zij stemt dus, wat haar oplosbaarkeid aangaat, geheel overeen met serumglobuline; 
door dialyse en door verzadiging der oplossing met $\mathrm{NaCl}$ wordt zij gedeeltelijk, door verzadiging der oplossing met $\mathrm{MgSO}_{4}$ geheel neergeslagen. Evenals uit het serum neergeslagen paraglobuline steeds met fibrineferment vermengd is, zo wordt ook het "zymogeen" met paragluboline uit het zoutplasma neergeslagen, maar terwijl in het serum, althans van sommige dieren, na saturatie met $\mathrm{MgSO}_{4}$ nog een deel van het fibrineferment opgelost blijf, is dat bij saturatie van het plasma met $\mathrm{MgSO}_{4}$ niet het geval met zymogeen.

De globuline, door verzadiging van $\mathrm{MgSO}_{4}$ of oxalaatplasma, na verwijdering van het fibrinogeen, met $\mathrm{MgSO}_{4}$ neergeslagen, werd afgefiltreerd in gedestilleerd water opgelost, daaruit weer door verzadiging met $\mathrm{MgSO}_{4}$ neergeslagen, afgefiltreerd, op de filter met een verzadigde oplossing van $\mathrm{MgSO}_{4}$ gewassen en daarna met weinig water in een dialysator gebracht. Aanvankelijk lost dan de globuline in de dialysator op, om daarna, als de vloeistof zeer arm aan zout geworden is, weer neer te slain. De troebele inhoud van de dialysator bracht nu steeds stolling teweeg in zuivere oplossingen van fibrinogeen, onder voorwaarde dat kalkzouten in oplossing aanwezig waren - het heldere filtraat van de dialysator inhoud eveneens, maar steeds langzamer. In het laatste geval was ook telkens het gevormde coagulum weker en de afgescheiden fibrine geringer in hoeveelheid. Niet alleen oplossingen wan $\mathrm{CaCl}_{2}$ en $\mathrm{CaSO}_{4}$ kunnen hierbij dienst doen, maar ook kalkwater, wanneer daarvan tenminste slechts zeer weinig wordt toegevoegd zodat de reactie niet meer dan zeer zwak alcalisch wordt.

Verder:

Men kan nu uit de van het plasma afkomstige globuline, die zelve niet de minste stolling in een fibrogeenoplossing teweeg brengt, een krachtig werkend fibrineferment bereiden. Daartoe wordt de globuline op de boven aangegeven wijze door herhaalde precipitatie met $\mathrm{MgSO}_{4}$ van serumalbumine bevrijd, door dialyse arm aan zout gemaakt, en dan enige tijd (één à drie uren) bij een temperatuur van 25 a $35^{\circ} \mathrm{C}$ met een overmaat van $\mathrm{CaCl}_{2}$ gedigereerd. Meestal blijkt het dan dat door de behandeling van het plasma met $\mathrm{NaCl}$ het fibrinogeen niet 
volkomen verwijderd is; er vormt zich een week coagulum, dat gemakkelijk uit de vloeistof weggenomen kan warden. Dan wordt de vloeistof door dialyse van het overtollige $\mathrm{CaCl}_{2}$ bevrijd. De globuline lost door de toevoeging van $\mathrm{CaCl}_{2}$ wel voor een deel, maar niet geheel op.

De vloeistof is dus troebel wanneer zij in de dialisator komt en wordt nu steeds sterker troebel naarmate zij armer wordt aan zout. Daarbij. wordt, evenals uit het zoutplasma het zymogeen, zo ook hier het ferment grotendeels neergeslagen. Wordt na krachtige dialyse de inhoud van de dialysator gefiltreerd, dan vertoont het heldere filtraat slechts een zeer zwakke fermentwerking, terwijl het precipitaat, met een oplossing van fibrineferment gemengd, daarin weldra volkomen stolling teweeg brengt. Dit ferment wordt door verzadigen van de oplossing met $\mathrm{MgSO}_{4}$ volkomen neergeslagen.

Het kan dus, evenmin als het zymogeen, op de wijze die door Hammarsten voor bloedserum aangegeven is van de paraglobuline gescheiden worden. Het ferment wordt werkeloos door het op $\pm 60^{\circ} \mathrm{C}$ te verhitten en ontstaat niet wanneer het presipitaat van globuline uit het zoutplasma, voordat daaraan het $\mathrm{CaCl}_{2}$ is toegevoegd, op die temperatuur verwarmd wordt. Het onwerkzaam worden ligt dus niet aan de paraglobuline, die gelijk bekend is, door een temp. van $60^{\circ} \mathrm{C}$ niet veranderd wordt, maar aan een daarmee gemengde stof, die door verzadigen van de oplossing met $\mathrm{NaCl}$ en door dialyse grotendeels, door verzadigen met $\mathrm{MgSO}_{4}$ volkomen wordt neergeslagen. Over het voorgaande merkt Pekelharing verder op:

Het mag daarom, naar het mij voorkomt, als bewezen beschouwd worden dat, met behulp van een kalkzout fibrineferment gemaakt kan worden uit een in zoutplasma voorkomende stof die op de wijze van globuline geprecipiteerd wordt.

Ook heeft hij een vermoeden gehad dat wat men in die tijd thrombine noemde wel eens een ander stollingsbevorderend principe kon zijn, getuige zijn opmerking:

De vraag zou intussen gesteld kunnen worden of men het recht heeft aan te nemen dat er slechts één fibrineferment bestaat. Vooreerst is de temperatuur waarbij een fermentoplossing 
werkloos wordt door verschillende onderzoekers verschillend gevonden. Soms verloor de oplossing hat fibrinoplastische werking reeds door verwarning op $60^{\circ} \mathrm{C}$, in andere gevallen kon zij tot $80^{\circ} \mathrm{C}$ of zelfs hoger verhit worden zonder haar werkzaamheid te verliezen. En hij vervolgt: In deze verschillen wordt echter door niemand, voorzover ik heb kunnen nagaan, een grond gevonden om het voorkomen van verschillende fibrinefermenten aan te nemen.

Daarna somt hij verschillende mogelijkheden op waardoor deze temperatuur verschillen zouden kunnen ontstaan en vervolgt:

Een andere grond, van meer betekenis om er aan te twijfelen of alle fibrineferment als dezelfde stof beschouwd mag worden, ligt hierin dat het ferment meestal de eigenschappen van een globuline vertoont, maar toch ook zoals Hammersten heeft aangetoond, zodanig bereid worden kan dat het noch door dialyse noch door verzadiging van de oplossing met $\mathrm{MgSO}_{4}$ neergeslagen wordt.

Halliburton heeft intussen proeven beschreven (Journ. of Physiol. Vol. IX, 1888 p. 260) waarbij bleek dat uit het bloedserum van de kat en van het schaap en uit het serum van een gestold ascitesvocht van de mens, het ferment door verzadiging met $\mathrm{MgSO}_{4}$ volkomen werd neergeslagen, zodat bij deze vloeistoffen een bereiding naar de methode van Hammersten niet mogelijk was. Voorts vond hij dat het filtraat van met $\mathrm{MgSO}_{4}$ verzadigd paardenserum, waarin zoals bekend is, nog een ruime hoeveelheid ferment in oplossing voorkomt, na langdurige dialyse opnieuw door $\mathrm{MgSO}_{4}$ geprecipiteerd kon worden en dat door het verzadigen van de vloeistof met dit zout, en het dialyseren van het filtraat driemaal te herhalen, tenslotte alle ferment uit het serum kon worden neergeslagen.

Dat Pekelharing het prothrombine niet uit cellen bereidde, maar wel dacht dat het uit de cellen kwam, blijkt uit het volgende: (Onderzoekingen $4 \mathrm{e}$ reeks I, p. 101) waar hij zegt: Het komt mij voor dat het bij het onderzoek naar de werking van verschillende stoffen die in en buiten het levend lichaam de neiging van het bloed om te stollen hetzij vergroten, hetzij ver- 
minderen, nuttig zou zijn dat de aandacht zowel op de in het bloed opgeloste kalkzouten als op het van de cellen afkomstige zymogeen te vestigen. Wellicht kan daardoor iets worden bijgedragen tot de oplossing van de zo hoogst gecompliceerde problemen, waarop men bij de studie van de oorzaken der stolling wan het bloed telkens stuit.

\section{c. De plaats van Pekelharings ontdekking in zijn tijd}

Het nu volgende citaat getuigt, dat Pekelharing zich de omvang en de complexiteit van de bloedstolling duidelijk voor ogen stelde. Hij zegt: (Ibid. p. 115) dan: Het vraagstuk van de oorzaak der stolling is zo uitgebreid en niet alleen voor de kennis van het bloed, maar ook woor de kennis van nagenoeg alle, zo niet alle dierlijke weefsels van zo groot gewicht en zo samengesteld dat er voorlopig wel niet aan te denken valt daarin een bevredigend inzicht te verkrijgen.

Als we het werk van Pekelharing met dat van Schmidt vergelijken zien we dat de 17 jaar jongere Pekelharing zijn eerste werk over de stolling publiceert in 1891 (hij is dan 43 jaar) terwijl Schmidt in 1861 publiceert op 30 jarige leeftijd. Pekelharing is al een ervaren onderzoeker als hij aan dit onderzoek begint en heeft kennis kunnen nemen van een menigte meningen en opvattingen van eerdere werkers. Schmidt begint, als minder door de woll geverfd onderzoeker aan een veel slechter geëxploreerd gebied. Ondanks het relatief geringe verschil in leeftijd moeten we ze als onderzoekers van twee geheel verschillende generaties beschouwen. Waar Schmidt tastenderwijs voortgaat in een onontgonnen gebied, vele experimenten doet, vele dwaalwegen inslaat en uiteindelijk niet tot een conclusie kan komen heeft Pekelharing de gelegenheid en het vermogen met enkele, ogenschijnlijk eenvoudige proeven de lucht van vele onhoudbare hypothesen te zuiveren.

Gedeeltelijk zal dit het gevolg zijn van the state of the art in het gebied. Gedeeltelijk is het zeker ook een persoonlijkheidskwestie. Men krijgt de indruk dat de artistieke, of althans tot 
het filisophische neigende Schmidt zich in zijn ondoorzichtige theorieên niet ongelukkig voelt, terwijl de heldere Pekelharing met feilloze precisie tot de juiste conclusies komt omdat deze benadering hem het beste ligt. Toch kan ook dat slechts ten dele juist zijn. Als men niet de geschiedenis van de wetenschappelijke voortgang van de bloedstolling schrijft maar die van de ontdekking van het vitamine B kan men maar al te gemakkelijk Pekelharing in de rol van Schmidt plaatsen en Eykman in de roll van Pekelharing.

Kortom, ook historisch onderzoek blijft een kwestie van benaderen, temeer daar men niet zoais bij het stollingsonderzoek het te bestuderen phenomeen, $n 1$. de onderzoekers van die dagen zelf, in de werkelijkheid kan oproepen. Wel kan men, zoals wij al eerder deden de proeven herhalen en nagaan wat $\mathrm{zij}$, in onze termen hebben gezien en daardoor beter gissen hoe zij hun waarnemingen hebben geinterpreteerd.

Het lijdt vanzelfsprekend geen twijfel dat Pekelharing niet het prothrombine maar een mengsel van alle $\mathrm{nu}$ bekende stollingsfactoren in handen heeft gehad. In tegenstelling met de bevindingen bij eerdere onderzoekers, heeft men hier echter geen reden om aan te nemen dat de mogelijkheid van grote verwisselingen als die tussen thrombine en thromboplastine het beeld vertroebelt. Pekelharings proeven laten zich om te beginnen haarfijn reproduceren, en verder is zijn interpretatie, nl. dat er prothrombine in het bloed moet zitten een duidelijke minimumhypothese. Pekelharing vermoedt al dat er meer aan de hand kan zijn, maar zonder tenminste aan te nemen dat er een proenzym van het thrombine in het plasma zit, kan hij zijn proefresultaten in ieder geval niet interpreteren. Men vraagt. zich af wat hij zelf van zijn vondst vond. Hij noemt het woord prothrombine nergens in een van de titels ${ }^{1}$ van zijn publikaties, wat overigens toch een voortreffelijke wijze om een belangrijke vinding duidelijk te etaleren is. Waarschijnlijk las men in Pekelharings tijd nog wel geregeld de hele artikelen en beperkte men zich niet tot titels en samenvattingen zoals men nu, gesanctioneerd door de titel- en uittrekselcompilaties, zo vaak doet.

11 Deze titels zijn hierachter in een tabel samengevat (zie tabel III) 
Wij hebben de proef van Pekelharing vier malen herhaald om daarna de factoren gehaltes van de tot het oorspronkelijke volume opgeloste neerslagen $A_{3}$ en $B_{3}$ te bepalen. Van een representatieve proef zijn de resultaten in Tabel IV samengevat. De andere drie gaven een vergelijkbaar beeld te zien, met name wat betreft het hoge gehalte van de factoren V, VII, IX en X in het prothrombine preparaat.

Het is duidelijk dat beide preparaten zoals te verwachten was in hoge mate onzuiver zijn, maar ook dat Pekelharing door het gebruik hiervan terecht tot het bestaan van prothrombine moest concluderen. Het is interessant om te zien hoezeer het prothrombine van Pekelharing lijkt op het prothrombine van Seegers. Zoals bekend heeft Walter Seegers jarenlang vastgehouden aan het idee dat de vier factoren II, VII, IX en X één molecuul, het prothrombine molecuul, vormden. Hij baseerde deze veronderstelling op zijn waarneming dat het, met de hem ten dienste staande middelen onmogelijk was deze vier factoren te scheiden. Door een toeval mocht de schrijver in 1964 getuige zijn van de dramatische confrontatie tussen Seegers en Macfarlane op het congres van het International Committee for the Nomenclature of Blood Clotting Factors in 1964 te Amsterdam. De pen van een romanschrijver zou de situatie meer recht doen dan de mijne, ik zal dan ook niet trachten tot een aedequate beschrijving te komen maar alleen herinneren hoe Seegers, door de vriendelijke maar onontkoombare oppositie van Macfarlane, Esnouf en anderén gedwongen toe te geven dat het concept dat hij sinds het begin van de dertiger jaren gekoesterd had niet houdbaar bleek in een heftige emotionele uitbarsting van zijn onvrede met de situatie blijk gaf.

Men kan zonder enige overdrijving zeggen dat Seegers en Pekelharing vrijwel hetzelfde prothrombine voor de geest hadden. Ook al wist Seegers inmiddels oneindig veel meer van de bloedstolling dan Pekelharing ooit zou weten. De ontdekking van Pekelharing heeft dus tot het jaat 1964 in gezaghebbende kringen volledig doorgeklonken, zij het zonder dat zijn naam erbij bekend was.

Het is merkwaardig om te zien dat de gebeurtenis die in 1964 
voor het eerst mijn belangstelling wekte, niet alleen voor de bloedstolling maar ook voor de geschiedenis van haar ontsluiering en de persoon van de mannen die daarvoor verantwoordelijk waren, dat deze gebeurtenis uitvloeisel was van Pekelharings originele waarneming. Uit zijn bewijsvoering is weinig twijfel te proeven en toch blijft men een duidelijker, vooral internationaal poneren van zijn vinding missen. 


\section{TABEL III}

Lijst van Pekelharings publikaties van de bloedstolling in internationale tijdschriften

1891 Ueber die Bedeutung der Kalksalze für die Gerinnung des Blutes

Internationaler Beitrag zu Rudolph Virchow's Festschrift $l 433$

1892 Ueber die Gerinnung des Blutes

Deutsche med. Wochenschrift 101133

1895 Ueber die Beziehung des Fibrinfermentes aus dem Blutserum zum Nucleoproteid welches aus dem Blutplasma zu erhalten ist

Centralbl. Physiol. 9102

1903 Met W. Huiskamp

Die Natur des Fibrinferments

Zeitschr. physiol. Chem. 3922

1908 Ein Paar Bemerkungen über Fibrinferment

Biochem. Zeitschr. 111

1913 Das Aktivieren von Blutserum

Zeitschr. physiol. Chem. 85341

1914 Ueber den Einflusz von Phosphatiden auf die Blutgerinnung

Zeitschr. physiol. Chem. 8922 
Analyse van het fibrinogeen preparaat en het thrombinepreparaat bereid volgens Pekelharing

\begin{tabular}{|l|cc|cc|}
\hline Stollingsfactor & \multicolumn{2}{|c|}{$\begin{array}{l}\text { Fibrinogeen } \\
\text { preparaat }\end{array}$} & \multicolumn{2}{|c|}{$\begin{array}{l}\text { Prothrombine } \\
\text { preparaat }\end{array}$} \\
\hline I & \multicolumn{2}{|c|}{$0.67 \mathrm{mg} / \mathrm{ml}$} & \multicolumn{2}{|c|}{$0.02 \mathrm{mg} / \mathrm{ml}$} \\
II & 0.4 & $\%$ & 24 & $\%$ \\
V II & 12 & $\%$ & 17 & $\%$ \\
VIII & 8 & $\%$ & 35 & $\%$ \\
IX & 4 & $\%$ & 4 & $\%$ \\
X & 0.7 & $\%$ & 19 & $\%$ \\
\hline
\end{tabular}




\section{d. Wat heeft Pekelharing waargenomen?}

De essentiele proef van Pekelharing kan men a.h.v. samenvatten:

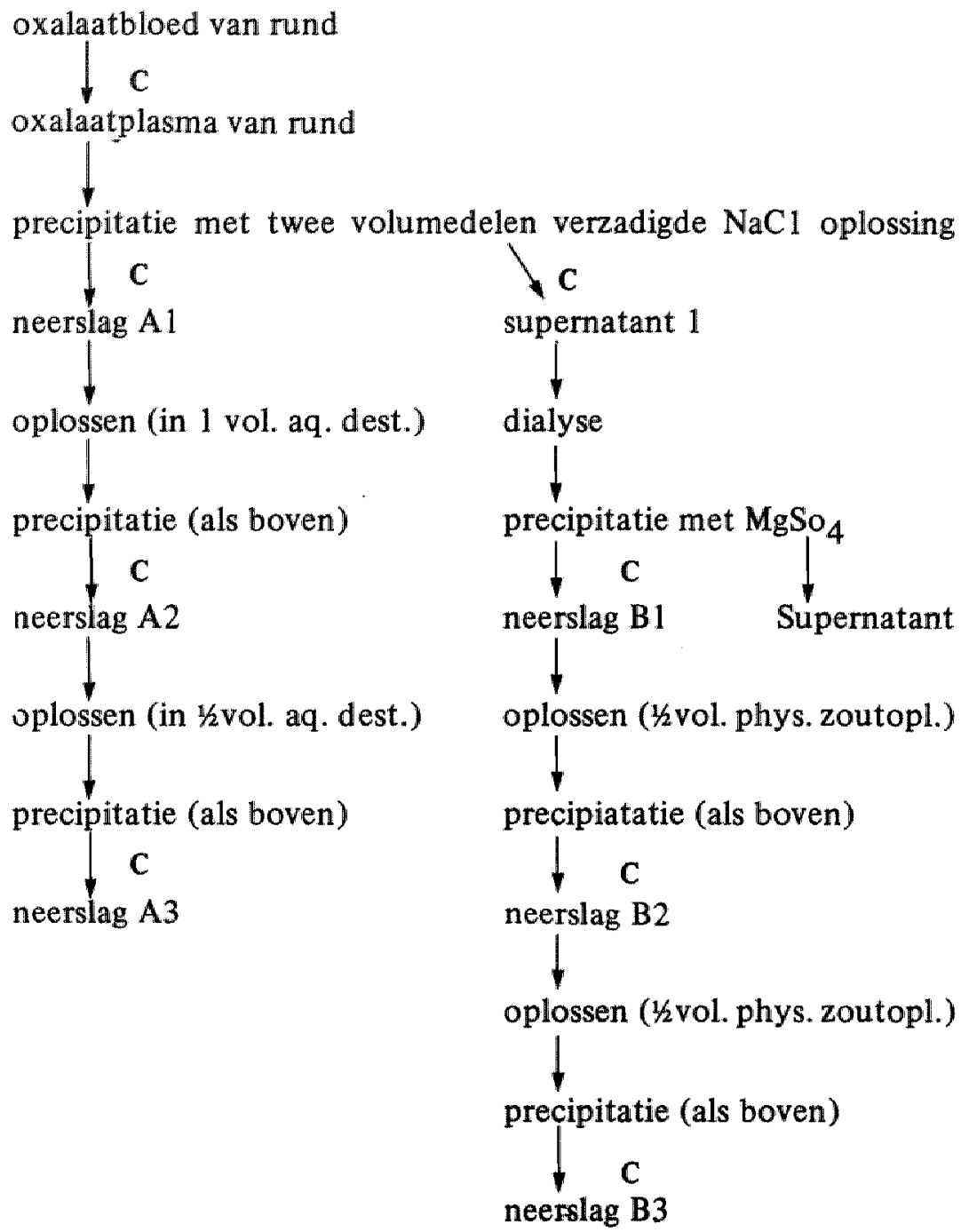


Het opgeloste neerslag A3 stolt niet door toevoeging van $\mathrm{Ca}^{++}$, maar wel door toevoeging van thrombine.

In het opgeloste neerslag B3 kan men door toevoeging van $\mathrm{Ca}^{++}$ hoogstens een lichte fibrinevorming waarnemen maar altijd onstaat er een krachtige thrombineoplossing. Verhitten van het opgeloste neerslag B3 vóór de recalcificatie verhindert de thrombinevorming.

( $C=$ centrifugatie). 


\section{e. Hoe stelde Pekelharing zich het prothrombine voor?}

Het zou mooi zijn als we hier de discussie over Pekelharings ontdekking konden afsluiten. Welhaast bij toeval echter zijn wij in staat ons een duidelijk beeld te vormen niet alleen van wat Pekelharing gedurende zijn werk aan thans nog geldige inzichten had verworven, maar ook van wat hij nog niet wist of waarover hij sindsdien achterhaalde opvattingen koesterde. In 1919, een jaar na zijn emeritaat publiceert hij Some remarks on enzymes, dat hij a.h.v. begint: The remarks put fonward in this paper on the comprehensive subject of the action and the nature of enzymes were intended as a guide for a lecture $I$ was prevented from delivering. Now that I am no longer in a position to participate in experimental inquiry I feel inclined to publish them as a concise, and, it must be added, as a very incomplete compendium of the conceptions I derived from the work of others and partly also from my personal investigations.

$\mathrm{Na}$ een uitgebreide inleiding waarin hij aantoont dat Johannes Baptist van Helmont (1577-1644) de eerste is die het concep ferment in de moderne zin gebruikt voor wat zij nu enzymen van het spijsverteringskanaal noemen en uitgebreide beschouwingen over pepsine, lipases en suikersplitsende enzymen komt het thrombine ter sprake. Hij zegt: Blood-plasma protected from coagulation in one way or other, does not contain thrombin. It does contain, however, a mothersubstance of it that by the addition of limesalt, is converted into thrombin. From such a plasma may be prepared a nucleo-proteid that can be converted into thrombin, with the aid of lime. Maar gaat even later verder: Not only nucleoproteids of the blood-plasma, but also those prepared from all sorts of organs, thymus, liver, kidney, testis, muscles, spleen, glandula submallilaris are capable of coagulating, as soon as they combine with lime, a fibrinogen solution in quite the same way as the thrombin of the bloodserum. Not all workers have been in a position to confirm this experience. This proved to be due to the fact that they did not purify the nucleoproteids and the fibrinogenous 
matter as well as could be "but used for their experiments extracts of organs and bloodplasma, fluids contraining a number of other substances, which could unhibit or even prevent the formation of fibrin. The nucleoproteids from which the thrombin is evolved that makes the blood coagulate, when it is drawn from the body, are produced by the corpuscles floating in the blood, in the first place by the blood-platelets, which are injured on issuing from the vessels. Then the nucleoproteid in combination with the limesalts in the blood, forms thrombin. On injection of not too small a quantity of nucleoproteid into the blood of a healthy animal, notably a rabbit, will evolve, with the aid of limesalts present in the blood, thrombin and consequently fibrin in the flowing blood by which the bloodvessels are obstructed.

Hier zien we dat met grote waarschijnlijkheid Pekelharing het prothrombine verwart met allerhande preparaten met thromboplastische activiteit zoals die gemakkelijk uit verschillende organen bereid kunnen worden.

Met andere woorden: De thromboplastine-achtige weefselextracten die Schmidt en anderen gedurende een halve eeuw op dwaalsporen hadden geleid en verhindert hadden de ware aard van het thrombine duidelijk te laten worden vóor Hammersten en Pekelharing hier klaarheid schiepen, zijn terug. $\mathrm{Z}_{\mathrm{ij}}$ zijn slechts één stap in het stollingsschema opgeschoven, zelfs in de gedachtenwereld van de ontdekker van het prothrombine, zelfs 15 jaar na de hypothese van von Morawitz. Een vondst als deze doet ons nogmaals beseffen hoe betrekkelijk de waarde kan zijn van het toekennen van bepaalde ontdekkingen aan bepaalde onderzoekers.

Weliswaar kwam Buchanan tot de juiste conclusie over de werking van thrombine en op grond van de goede proeven, maar uit zijn eigen proeven en vooral uit die van Schmidt blijkt dat niemand het in die tijd van thromboplastine kan afgrenzen. M.a.w. Buchanans thrombine is het onze niet, al kan het er ook niet van onderscheiden worden.

Evenzo is Pekelharings prothrombine begrip duidelijk verschillend van het onze, ja zelfs van dat van Seegers. 
Zo goed als Pekelharing het begrip thrombine modificeerde van het vage $19 \mathrm{e}$ eeuwse concept tot iets dat vergelijkbaar is met ons huidige begrip, evenzo zal de ware aard van het door Schmidt gepostuleerde en door Pekelharing aangetoonde prothrombine pas in de halve eeuw na het verschijnen van Pekelharings laatste artikel langzaam duidelijk worden. Wanneer men zich hier rekenschap van geeft kan het niet anders of men wordt getroffen door klaarblijkelijk geweldige ondoorzichtigheid van dit soort fysiologische problemen op het moment dat zij zich als eerste vraagstelling aan de onderzoeker opdringen. Meer nog dan naar de hier of daar geslaagde stap voorwaarts die aan één bepaalde onderzoeker kan worden toegeschreven, bewonderen wij de continue inspanning van al die onderzoekers die aan het oplossen van deze problemen hun krachten wijden, met het uiteindelijke resultaat dat men op basis van de verkregen inzichten allerlei ziekten beter kan behandelen.

Aan Buchanan, aan Schmidt, aan Pekelharing en aan tientallen latere onderzoekers is het b.v. te danken dat de eens zo gevreesde veneuse thrombose nu een practisch bezworen ziektebeeld genoemd kan worden. De doeltreffende bestrijding van de arteriele thrombose, op dit moment de belangrijkste doodsoorzaak in de westerse maatschappij, zal eens te danken zijn aan deze zelfde onderzoekers en aan de honderdtallen meer die zich op dit moment aan het hemostase en thrombose onderzoek wijden. 


\section{HOOFDSTUK VI}

\section{HET LEVEN VAN CORNELIS ADRIANUS PEKELHARING}

Par. 1. Jeugd te Zaandam

Par. 2. Studietijd

Par. 3. Eerste praktijkjaar en arts te Leiden 1872-1878

Par. 4. De jaren aan de Rijks-veeartsenijschool te Utrecht 1878-1881

Par. 5. Hoogleraar aan de Med. fac. der Rijks Univ. te Utrecht 1881-1918

Par. 6. Pekelharing en de beri-beri

Par. 7. De jaren in het Physiologisch Laboratorium 1888-1918

Par. 8. Pekelharing, de med. opleiding en de Mij der Geneesk.

Par. 9. Omstreeks de eeuwwisseling en later

\section{a. Jeugd te Zaandam}

Cornelis Adrianus Pekelharing werd op de $19 \mathrm{e}$ juli 1848 te Zaandam geboren als.zoon van Cornelis Pekelharing, Medicinae Doctor en Johanna van Ree.

Het geslacht Haringh was afkomstig uit Zaandam. Het bezat daar reeds in de $17 \mathrm{e}$ eeuw enige olieslagerijen en begaf zich in deze tijd ook in de olie en lijnzaad handel, een branche die toen van groot economisch belang was. ${ }^{1 / 2}$

12 De lijnolie wordt gewonnen uit de zaden van het vlas. De vlasplant (Linum usitatissimum) werd in Holland en België doch ook in Bohemen, rond Archangel en in Egypte verbouwd. De olie behoort tot de drogende vette oliën en wordt uit hèt zaad bereid. Eeuwenlang is ze gebruikt voor verlichting en als verfbasis. De zaden van het vlas zowel als de olle werden in de geneeskunde gebruikt. Het lijn- 


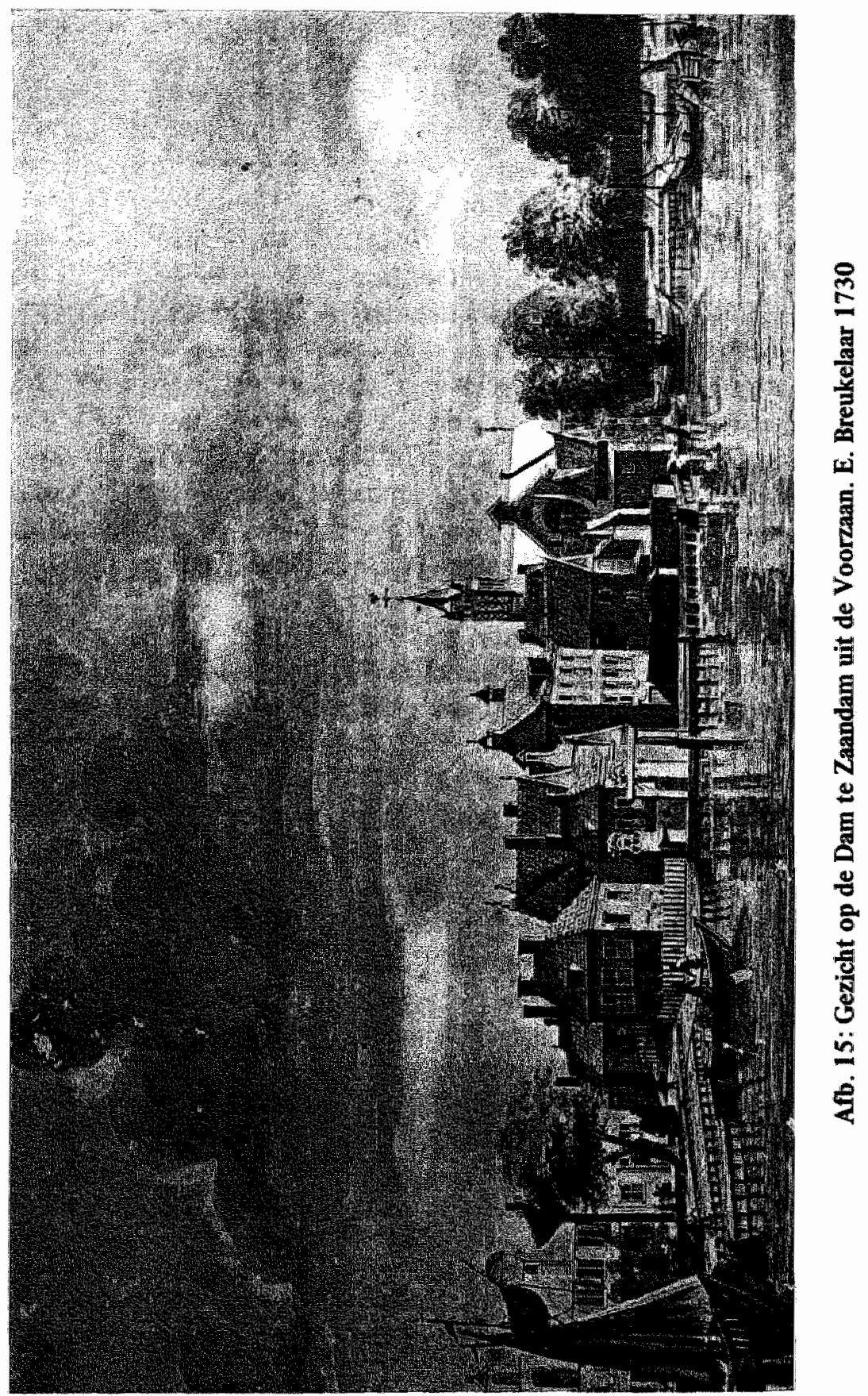


Van de twee broers Arijs en Jilles Haringh ging Jilles zomers op walvisvaart bij Groenland. Hij werd daarom in Zaandam Pekelharing genoemd en deze naam bleef ook daarna de familienaam van zijn nakomelingen. Zij bleven anderhalve eeuw geziene handelaars in de Zaanstreek. Cornelis Pekelharing was de eerste dokter in de familie.

In de Franse tijd was de klad gekomen in de lijnzaadbranche. $\mathrm{Na}$ vele generaties werd daarom de familietraditie onderbroken en verkoos een Pekelharing een academische studie boven de handel. Zijn studiekeuze toonde echter nog een duidelijke practische inslag. Hij besloot plattelandsheelmeester te worden, en liet zich daartoe inschrijven aan het Atheneum Illustre te Amsterdam. ${ }^{13}$

zaad vooral bij ontstekingen van de urinewegen, de olie voor verzachtende lavementen en bij verbrandingen.

De lijnkoeken die overbleven na uitpersing wan het zaad dienden tot veevoer maar werden ook vermalen tot lijnzaadmeel. Dit lijjnzaadmeel was de grondstof bij de vervaardiging van lijnzaadpappen in de farmacie en werd toegepast bij de bereiding van zepen en vernissen.

${ }^{13}$ De geneeskunde werd aan het Atheneum Illustre voor het eerst onderwezen door Blasius, na zijn benoeming in 1660. Dat wilde niet zeggen dat er van toen af aan een reguliere medische faculteit bestond. Integendeel. Bij besluit van 1679 werd het onderwijs in de geneeskunde aan het Atheneum, "gemortificeerd" maar daarmee niet uit Amsterdam gebannen omdat het chirugijnsgille zijn eigen professoren, zoals Tulp en Ruijsch behield. Lange jaren zijn er wat onduidelijke verhoudingen tussen het Collegium Chirurgicum en het Atheneum. Daarin komt pas enige duidelijkheid als in 1755 de hoogleraren Roêll, Burman en Camper aan het Atheneum worden benoemd en het onderwijs daar onder éen noemer trachten te brengen met dat van het Collegium Chirurgicum en het Collegium Medicum. Pas in 1798 worden beide laatste lichamen opgeheven en komt het geneeskundig onderwijs centraal bij het Atheneum. Als stiefkind overigens want eerst sinds 1832 bestaat er een Genees- Heel en Verloskundige school die als het aequivalent van een medische faculteit kan worden gezín en waarvan $\mathrm{D} J$ : van Lennep, de rector magnificus, bij het tweede eeuwfeest van het Atheneum, gewag maakt in zijn herdenkingsrede, als een volwaardige tak van de jubilerende school. 
In die tijd begon Comelis Pekelharing zijn studie. Tijdens zijn studietijd raakte Cornelis Pekelharing geinteresseerd in de leer van de smetstoffen doordat zijn leermeester Prof. Van der Breggen ${ }^{14}$ hem opdracht gaf een artikel daarover van de hand van Naumann (Bonn) te vertalen. Zo'n vertaling was noodzakelijk om de stof toegankelijk te maken voor de vele plattelandsgeneesheren, opgeleid aan een chirurgijnsschool "oude stijl" die het Duits evenmin als het Latijn of Grieks beheersten, misschien slechts een mond vol Frans........

De vertaling van het artikel van Naumann was aanleiding voor Cornelis Pekelharing meer litteratuur over de smetstoffen te bestuderen. De materie interesseerde hem bijzonder en daar een en ander ook de instemming van Prof, van der Breggen had, besloten zij dat hij hierover een dissertatie zou schrijven. Het werk handelt over de dampen die uit de moerassen opstijgen en die op deze wijze besmetting zouden veroorzaken. Zoals bekend meende men toen ter tijd, dat ziekten als malaria door zulke dampen zouden ontstaan en verspreid worden. Zijn proefschrift was getiteld De effluviis paludosis. ${ }^{15} \mathrm{Hij}$ promoveerde bij Prof. van der Breggen en verdedigde zijn proefschrift voor de Senaat van de Utrechtse Hoogeschool in 1837 , het Atheneum Illustre te Amsterdam kende immers het JUS PROMOVENDI niet.

$\mathrm{Na}$ zijn promotie ging Cornelis in de leer bij Dr. Baltus van Ree te Oostzaan. Ook toen al zal de academische opleiding niet helemaal bij de praktijk van alledag hebben aangesloten en was een leerperiode bij een ervaren prakticus noodzakelijk. De jonge dokter maakte daar kennis met Johanna van Ree, de dochter van zijn leermeester.

$\mathrm{Na}$ zijn verloving in 1839 trouwden zij in 1840. Zijn vrouw wist maar al te goed wat de praktijk van een dokter op het platteland betekende met te dien tijde slechte wegen en vervoermiddelen in het Zaanse waterland. In het jonge gezin ${ }^{14}$ Frans van der Breggen Cornelisz, wordt in 1784 te Leiden geboren en in 1817 benoemd tot Professor pathologiae et medicinae forensis aan het Atheneum Illustre. Hij nam ontslag in 1842 en overleed in 1843.

${ }^{15}$ Over de moerasdampen. 
werd eenvoudig geleefd en hard gewerkt om aan de kinderen een goede opvoeding te kunnen geven en in de nabije toekomst de zoons te kunnen laten studeren.

Johanna wan Ree wordt ons geschetst als een verstandige en zeer practische huisvrouw, die zich geheel aan haar groot gezin wijdde, zonder veel ontspanning te kennen. Wat men in die tijd al ontspanning noemde bestond uit niet veel anders dan een enkele bijeenkomst met vriendinnen, het z.g. "kransje" en een sporadisch bezoek aan familie buiten de stad. Het beeld zoals ons dat van een middenstandsfamilie in b.v. de Camera Obscura geschetst wordt. De familie woonde in een oud, kapitaal stenen huis dat in 1707 werd gebouwd aan de Westkant van de Voorzaan, temidden van houten huizen. Vroeger was er naast dit huis een scheepstimmerwerf, doch deze werd later geliquideerd en in een tuin veranderd. Daarna werd deze tuin bij het huis getrokken.

In het zich uitbreidend gezin groeide de jonge Kees voorspoedig op. Als het genotype van de mens voor zijn levensloop van overwegende betekenis is, zal zijn fenotype toch in hoge mate worden bepaald door de omgeving waarin hij opgroeit en zich geestelijk ontwikkeld.

Door hun zorgvuldige opvoeding hadden zijn ouders grote invloed op hem. Zijn vader was weliswaar een geleerde geneesheer van de oude stempel, doch zonder speciale wetenschappelijke intersse. Hij had een uitgebreide praktijk die lichamelijk veel van hem eiste. Zonder een bepaalde ontspanning of zelfs vakantie werkte hij onafgebroken naar beste weten aan het heil van zijn patiënten die hij zeer geregeld bezocht. Voor zover de tijd het toeliet las hij 's avonds vaktijdschriften om op de hoogte der geneeskunst te blijven.

De lagere school was in Zaandam zeer eenvoudig ingericht met een niveau dat juist voldoende was om een ijverige en begaafde leerling in staat te stellen "verder te leren". In feite kwam het er op neer dat een leerling voldoende inzicht en doorzettingsvermogen moest bezitten, om zich door studie eigen te maken wat aan hulpmiddelen bij het onderwijs ontbrak. Cornelis Adrianus, kortweg Kees, hoorde tot die leerlingen. Hij had 


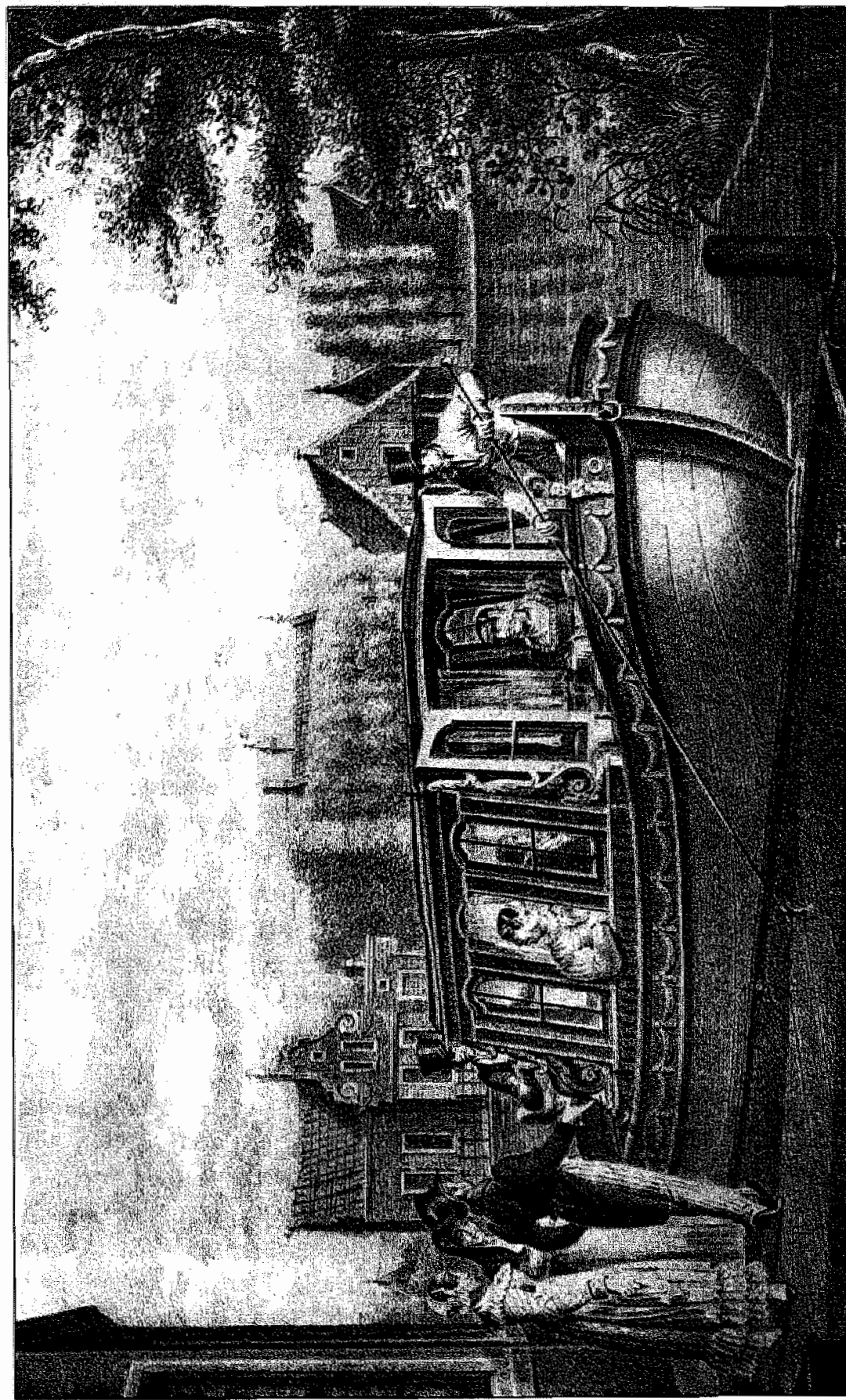

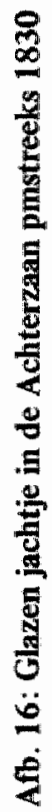


zes broers en een zuster en kwam dus uit een, wat we in deze tijd groot gezin zouden noemen. Hij was de derde zoon in het gezin. Zijin zuster was jonger dan hij.

De jonge Kees kwam nadat hij de lagere school in Zaandam gevolgd had, eerst bij de Heer Fortanier die later werd opgevolgd door de Heer Eykman op de "Franse school", die we als voortgezet lager onderwijs kunnen beschouwen. Na deze "met vrucht" gevolgd te hebben ging hij naar de hierop aansluitende Latijnse school van Dr. Jacob Roos. Deze was een erkend autoriteit op onderwijsgebied en hij heeft enige latere hoogleraren van naam op zijn school voor hun studentenloopbaan opgeleid. Zo ook Kees Pekelharing, die op zijn zeventiende jaar het admissie-examen van de hogeschool aflegde in oude en nieuwe talen benevens de wiskunde en hiervoor met glans slaagde. De opvoeding van Kees is waarschijnlijk gematigd vooruitstrevend geweest. Zijn vader was opgevoed in den Haag waar nog oude regenten tradities heersten, die aan de samenleving een aristocratische tint gaven. Zijn moeder Johanna van Ree was een meer democratische geest gewoon. $\mathrm{Zij}$ stamde uit een Keezenfamilie $^{16}$, zoals er in de Zaanstreek, vanouds een progressief industriegebied, vele voorkwamen.

Godsdienstig behoorde het geslacht Pekelharing tot de verdraagzame, rustige doopsgezinden. Johanna, ofschoon van huis uit Nederduits Hervormd, voelde zich, evenals later haar zoon Cornelis Adrianus, weinig tot de streng Calvinistische leer aangetrokken, zomin als haar ouders waarschijnlijk. In de meer "liberaal" gezinde Keezenfamilie heersten waarschijnlijk vrijere opvattingen. Dit neemt niet weg, dat men de zaken des geloofs in de familie Pekelharing wel enrstig nam, getuige het feit, dat de oudste zoon Dirk in Amsterdam theologie ging studeren en later predikant bij een doopsgezinde gemeente in Friesland werd.

Ofschoon het doktersgezin niet direct een brandpunt van religie of politiek was zullen er stellig gesprekken zijn gehouden

${ }^{16}$ Keezen waren Patriotten, een politieke stroming die tegen het einde der 18e eeuw ontstond. Het is een bijnaam (in feite scheldnaam) die de aanhangers van het Oranjehuis aan hun tegenstanders, de Patriotten gaven. 
over geloofszaken. Waarschijnlijk zullen de "moderne" opwattingen in de theologie, die vooral na 1860 opkwamen, er vrij enthousiast ontvangen zijn. Kees heeft echter zijn vader niet in het geloof kunnen volgen en de godsdienst betekende in zijn leven weinig voor hem.

\section{b. Studietijd}

Kees Pekelharing deed dus toelatingsexamen tot de Universiteit in 1865. Zijn vader vond hem echter nog te jong om hem alleen naar Leiden te sturen, zodat hij daar eerst een jaar later als student aankwam, waar ook zijn oudere broer Baltus staatswetenschappen studeerde en waar hij als lid van het Studentencorps werd ingeschreven.

Hij heeft de tijd van zijn $17 \mathrm{e}$ tot zijn $18 \mathrm{e}$ jaar echter niet onbenut gelaten en naar hij later vertelde reeds toen, thuis ijverig gewerkt in biologie, natuur-en scheikunde.

De leermeesters van de student Kees Pekelharing in Leiden waren de hoogleraren P.L. Rijke woor natuurkunde, A.H. van der Boon Mesch $^{17}$ voor scheikunde, J. van der Hoeven voor zoölogie en W.F.R. Suringar voor botanie.

De colleges anatomie en fysiologie werden door de hoogleraar A. Heynsius ${ }^{18}$ gegeven.

${ }^{17}$ Inderdaad, de van der Boon Mesch die (of liever wiens vrouw) er de directe oorzaak van was dat de veelbelovende teologie student J.J. van der Linde naar Engeland moest vluchten om daar een carrière als schoolmeester te vinden, onder welke naam wij hem ook in de Nederlandse poezie terugvinden.

18 Adrianus Heynsius was op 8 april 1831 te Moordrecht geboren. In 1848 werd hij ingeschreven als student in de geneeskunde en in de wis- en natuurkunde te Utrecht. Hij studeerde daar met een nadrukkelijke voorkeur voor de chemie en de fysiologie, bij G.J. Mulder, de eerste Nederlandse fysiologisch-chemicus. Donders de voornaamste fysioloog en oogheelkundige en Schroeder van der Kolk, dezelfde wiens proefschrift over de bloedstolling wij op pag. bespraken.

Hij promoveerde in beide faculteiten, in de eerstgenoemde op een proefschrift, "De sussurrorum vascularium explicatione physica", (Over de fysische verklaring der vaatgeruischen) in 1854 en in de 
De anatomie was destijds het voomaamste leervak en de fysiologie werd door dezelfde hoogleraar in de tweede plaats onderwezen, een toestand die wij heden ten dage eerder zouden omdraaien, maar die ook reeds Heynsius zelf al als moderner moet hebben gezien.

De klinische hoogleraren te Leiden in Pekelharing's studententijd waren G.C.B. Suringar en J.C.G. Evers voor het klinisch onderwijs dat toen ter tijd hoofdzakelijk de interne geneeskunde omvatte en J.A. Bogaard voor de pathologische anatomie. A.E. Simon Thomas voor de verloskunde, D. Doyer voor de oogheelkunde en $M$. Polano voor de chirurgie.

Cornelis Adrianus heeft, daar hij in 1866 aankwam, zijn opleiding genoten volgens de nieuwe gang van zaken, zoals deze geregeld werd bij de geneeskundige wetten van Thorbecke in 1865. Tijdens het tweede ministerie onder Thorbecke (1862-

laatstgenoemde op een dissertatie "Over de eiwitachtige lichamen" in 1853 .

In 1856 werd hij directeur van het kersverse laboratorium voor fysiologie en pathologie te Amsterdam gevestigd in een keukentje in het Binnengasthuis. In 1858 werd hij te Amsterdam hoogleraar in de fysiologie en pathologie aan het Atheneum Illustre, een leerstoel, die hij aanvaardde met een rede getiteld "De vertering van weelde in de dierlijke huishouding" een modern aandoend onderwerp, evenals de rede waarmee hij in 1866 zijn ordinariaat in Leiden aanvaardde: "Over het tegenwoordig standpunt der physiologie en haar verband met de geneeskunde". Ook in Leiden heeft hij de fysiologie als zelfstandig leervak gevestigd. In al zijn werken blijkt zijn interesse voor de chemie der "dierlijke eiwitstoffen", en de fysiologie van de bloedsomloop. Met Donders behoort hij tot de eerste fysiologen van Nederland, afgezien van een voorloper als Jacob Moleschott, die in 1848 reeds in navolging van Johannes Müller (1801-1858) de zelfstandigheid van de fysiologie opeiste. Bij de viering van het derde eeuwfeest van de stichting der Leidse Academie, hield Heynsius als rector magnificus een feestrede, getiteld: "over de zelfstandige beoefening der wetenschap". Zijn: "Verslagen van het fysiologisch laboratorium te Amsterdam" en "Verslagen van het physiologische laboratorium der Leidsche hoogeschool" waren zeer belangrijke bijdragen tot de fysiologie. Het fysiologisch laboratorium dat onder Heynsius leiding in Leiden werd gebouwd, kon toentertijd met de beste in het buitenland wergeleken worden. 


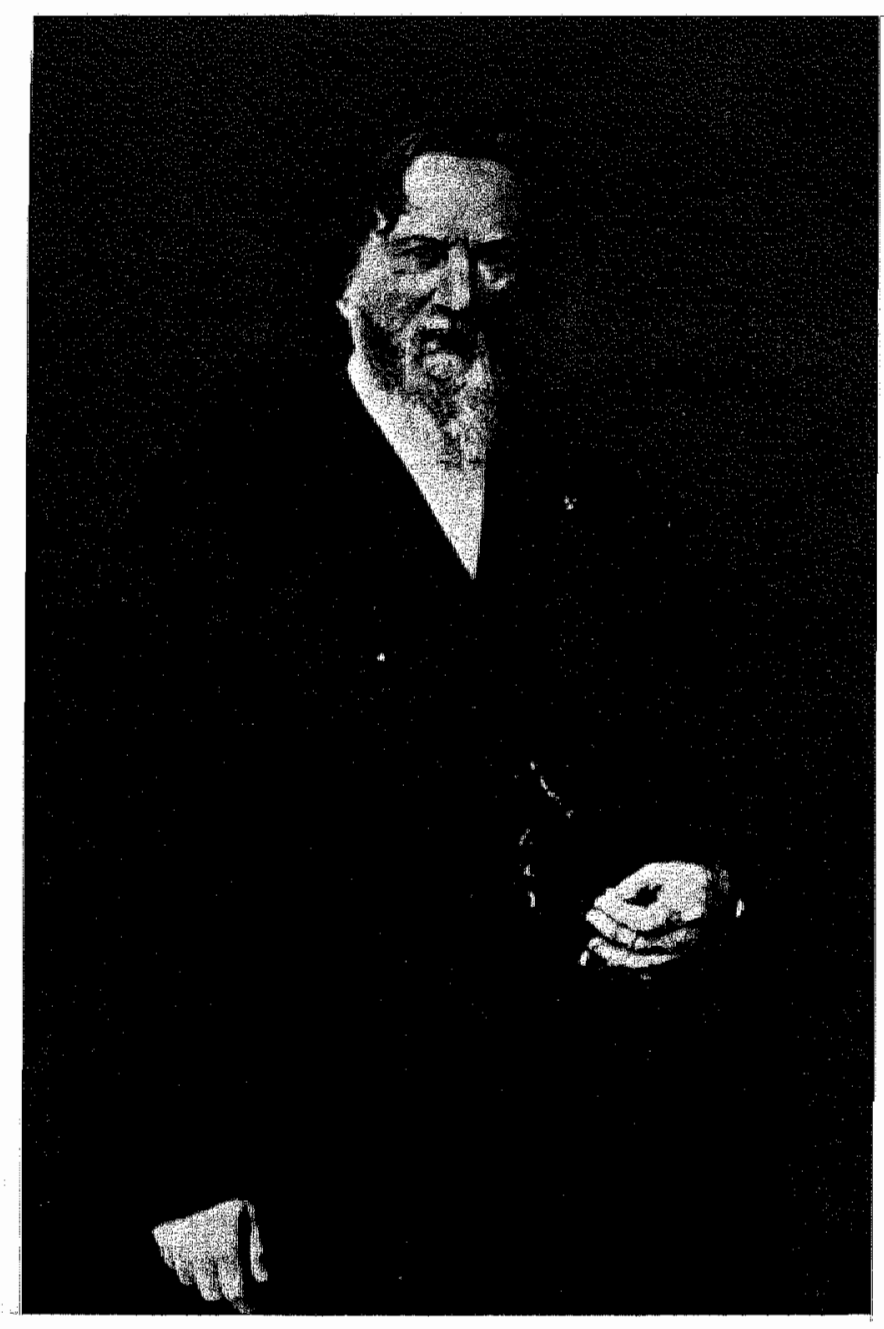

Afb. 16: Franciscus Cornelus Donders (1818-1889) 
1866) kwamen de nieuwe wetten tot stand. Deze regelden o.a. de eisen tot bevoegdheid en praktische bekwaamheid van hen die door een Staatscommissie tot arts werden bevorderd. Deze nieuwe toestand moest zich nog aanpassen aan de oude regeling, dus aan die vóór 1865 , toen aan de promotie nog de effectus civilis (wettelijke bevoegdheid verbonden aan een (universitair) diploma) was verbonden, maar de opleiding ook door b.v. een college van chirurgen kon worden verzorgd. Het gevolg hiervan was dat de artsenopleiding na de invoering van deze wetten, eveneens in 1865 , voorgoed bij de medische faculteiten der Universiteiten terecht is gekomen. De genoemde Staatscommissie werd opgeheven, toen in 1921, het afnemen der artsenexamens aan de medische faculteiten der Universiteiten werd opgedragen.

Cornelis Adriaansz. had eerst het candidaatsexamen in de natuurfilosofie afgelegd. Hij deed dit na twee jaar en vervolgens eveneens na twee jaar, dus in 1870 , het medisch candidaatsexamen (toenmaals, propadeutisch en groot mathesis genaamd). Dit examen omvatte de botanie en zoölogie, de chemie en de fysica, terwijl voor het onderdeel "groot mathesis" de kennis van o.a. de "hogere wiskunde" (differentiaal en integraal rekenen) en astronomie vereist was.

In de laatste twee jaar legde hij zich toe op de doctoraalstudie. In 1871 werd Pekelharing, kort na zijn medisch candidaats examen, assistent van Heynsius op diens fysiologisch laboratorium.

In mei 1872 volgde het doctoraal examen en kort daarna het staatsexamen, zoals dit toen bij de meergenoemde wet van Thorbecke geregeld was en dat nog niet in een eerste en tweede deel was gesplitst.

Het staatsexamen werd in dat jaar (1872) in het Binnengasthuis te Amsterdam afgenomen. De vakken waarin de candidaat werd geexamineerd waren anatomie en fysiologie, histologie en fysiologische chemie. Verder waren er $0 . a_{\text {. fysische en }}$ chemische diagnostiek, pathologische anatomie, chirurgie, oogheelkunde, interne geneeskunde en verloskunde.

Hij slaagde na een zeer zwaar examen en men fluisterde dat 
een zekere animositeit onder de klinische examinatoren, die van verschillende herkomst waren, hieraan niet vreemd was. Cornelis Adriaansz. verklaarde na afloop van het examen dat hij doodmoe was!

\section{c. Eerste praktijkjaar en arts te Leiden 1872-1878}

In 1873 , het jaar na het afleggen van zijn artsenexamen, nam Pekelharing in de zomer de praktijk van zijn vader in Zaandam waar. Zijn vader ging een buitenlandse reis voor zijn genoegen maken. Het was de eerste en de laatste van zijn leven want hij overleed in januari van het hierop volgend jaar.

De omgang van de jonge dokter met de patiënten was een succes zodat hij wilde proberen zijn theoretische en zijn praktische begaafdheden te kombineren door zich in Leiden als huisarts te vestigen en tevens assisstent op het fysiologische laboratorium te blijven. Dit bleek mogelijk. Hij kon niet alleen assistent blijven maar werd tevens in staat gesteld een proefschrift te bewerken op het fysiologisch-anatomisch laboratorium. Naast idealistische motieven zijn er ongetwijfeld ook economische geweest.

Bij zijn clubgenoot en collega Dr. J. Campert had hij te Zutphen kennis gemaakt met diens zuster. Later kwam zij te Zaandam logeren en hier leerde hij haar beter kennen. $\mathrm{Zij}$ verloofden zich in 1872 en trouwden de $14 \mathrm{e}$ juli 1873. Willemine Geertruida Campert wordt ons geschetst als weliswaar niet geleerd, maar, door haar natuurlijke vrolijkheid en gezond verstand een voortreffelijke echtgenote. $\mathrm{Zij}$ heeft hem vijf kinderen geschonken. In Leiden was Pekelharing's naam spoedig gevestigd. Zijn renommee als wetenschappelijk onderzoeker volgde snel, toen hij op 18 mei 1874 zijn dissertatie, getiteld: Over ureum bepaling in bloed en weefsels had verdedigd en "cum laude" tot medicinae doctor was gepromoveerd. Zijn promotor, de hoogleraar A. Heynsius noemde het proefschrift later: een dissertatie zelfstandig bewerkt en in de juiste vorm gegoten zoals een promotor zelden beleefd.

Zijn proefschrift gaf blijk van nauwkeurig en kritisch weten- 
schappelijk werk en liet, zoals later zal blijken, niet na de aandacht te trekken. Het salaris dat hij van het rijk ontving als: "adjutor in museo physiologico" was niet voldoende om erop te trouwen. Dit was zeker mede een reden om de praktijk naast het assistentschap te beoefenen. Zoals men ook heden nog vaak ziet eiste de praktijk hem steeds meer op, reden waarom hij in 1876 als assistent van Heynsius bedankte.

Toch vond hij in de huisartsenpraktijk op den duur geen voldoening. Hij moest bij het stellen van zijn diagnoses en bij zijn medicaties met teveel onbekende gegevens werken of kortsluiting maken naar de weinig wetenschappelijk gefundeerde, gebruikelijke behandelingsmethoden. Weliswaar had hij zijn colleges algemene en fysiologische pathologie met succes gevolgd, doch deze vakken waren nog te weinig ontwikkeld om een directe verbinding met de praktijk mogelijk te maken. Het was nog alles behalve de "Cellulairpathologie" van Virchow of een voorloper van de experimentele pathologie van Cohnheim. De fysiologische pathologie liet het aan het ziekbed nog te vaak afweten. Maar ook de fysische diagnostiek van Traube in Berlijn en de chemische diagnostiek van Stokvis, hoogleraar in de pathologie in Amsterdam en éen van de eerste leerlingen van Heynsius, kwamen in de praktijk bij het onderzoek van de patient te weinig tot hun recht.

De pathologische anatomie die althans de controle achteraf had kunnen leveren van zijn diagnoses der ziektegevallen, nam onder Prof. J.A. Bogaard extraordinarius voor dit vak, nog een heel bescheiden plaats aan de Leidse academie in en kwam in het dagrooster het laatst aan de beurt. Weliswaar genoot hij van de zijde van zijn patienten een groot vertrouwen als geneesheer, maar zijn verantwoordelijkheid als arts drukte hem nochthans te zwaar, juist omdat de praktijk zo weinig wetenschappelijk gefundeerd was. Bovendien voelde hij een blijvende drang, zelf medisch wetenschappelijke vraagstukken op te lossen door het experiment. Alles bijeen makte dat hij zich in zijn huisartsenpraktijk steeds minder gelukkig ging voelen. 


\section{d. De jaren aan de Rijks-veeartsenijschool te Utrecht, 1878-1881.}

Utrecht was in de jaren zeventig van de vorige eeuw een stad van rond 60.000 inwoners en het type van een deftige woonplaats met traditie. In de aloude bisschopsstad zetelde sinds 1853 weer een aartsbisschop. De stad was echter ook voor de Nederduits Hervormde Kerk een belangrijk steumpunt gebleven. Er waren centrale inrichtingen van het Rijk gevestigd zoals de Munt, het grootste en voornaamste Militaire Hospitaal en de Veeartsenijschool. ${ }^{18}$ Van de grootste betekenis voor de stad was nog steeds haar hogeschool, die tijdens de debatten in de tweede kamer der Staten Generaal over de hervormingen van het universitair onderwijs, (2e Ministerie Thorbecke, 1862-1866) voor de stad behouden was gebleven.

Donders ${ }^{19}$ was in die dagen een centrale figuur aan de universiteit.

${ }^{18}$ De veeartsenijschool was in 1819 door Willem I gesticht. $Z_{i j}$ was geen faculteit van de hogeschool, maar een aparte instelling die onder het ministerie van landbouw resorteerde. Pas in 1926 werd zij bij de universiteit als $6 \mathrm{e}$ faculteit ingelijfd. Niet zonder protest overigens van een aantal van haar (hoog)leraren die, terecht, de knappe beurs- van het ministerie van onderwijs duchtten. Maar kennelijk was het zoals we zullen zien omstreeks 1875 en later ook weer niet zo dat de hoogleraren van de faculteit der geneeskunde niet een belangrijke medezeggenschap hadden in de benoemingen aan de veeartsenijschool.

${ }^{19}$ Franciscus Cornelis Donders werd op 27 mei 1818 in Tilburg geboren, als zoon van kleine kooplieden zonder wetenschappelijke tradities. Zijn vader stierf een jaar na zijn geboorte en liet aan zijn moeder naast deze zoon nog negen dochters na.

Frans kwam op de lagere school bij meester Panken in Duizel bij Tilburg. Daar hij bijzonder goed rekenen kon werd hij op zijn elfde jaar aldaar ondermeester. Hier bleef hij drie jaar en verdiende in deze functie zijn eigen kost. Al na korte tijd op de Franse school in Tilburg viel er aan zijn Frans niet veel meer te verbeteren. Van hier kwam hij, daar zijn studiezin aan een ieder opviel, bij de paters in Boxmeer terecht om Latijn te leren. Zijn kennis, toen hij drie jaar later naar de Militaire Geneeskundige School in Utrecht vertrok, was, voor onze begrippen gering. Frans, Latijn en rudimen- 
Donders had als dertigjarige, in 1848 zijn intree-rede over "De Harmonie van het dierlijke leven" gehouden. In deze rede kwamen twee aspecten naar voren. Ten eerste was het een rationalistische aanval op het scheppingsverhaal en ten tweede een speuren naar de juiste theorie die deze my the moest vervangen, waarbij hij terecht kwam bij de evolutiegedachte zoals die naar voren kwam uit "On the origin of species" van Darwin (1859) en waarvoor in feite de eerste stap gedaan was door Lamarck (1801).

Sinds zijn benoeming heeft hij met niet aflatende ijver gewerkt aan de naam en faam van het Utrechts fysiologisch laboratorium. Bovendien had Donders te Utrecht het Nederlandsch Gasthuis voor behoeftige en mindervermogende ooglijders gevestigd in 1858 en deze kleine kliniek was dankzij zijn voortreffelijke leiding, rond 1870 tot een respectabele inrichting uitgegroeid. Naast Donders waren er te Utrecht in die tijd belangrijke andere geleerden zoals Beets, Buys Ballot en Harting. We mogen het Utrecht uit die tijd zeker een centrum van wetenschap noemen, maar ook van kunst, speciaal de toonkunst, die er in hoge eer werd gehouden.

ten van wis- en natuurkunde. Geen Duits, geen Engels, geen Biologie. Het is voor iemand die met de hedendaagse onderwijs toestanden op de hoogte is, moeilijk voor te stellen dat iemand met een dergelijk gebrek aan kennis werd toegelaten tot de Universiteit, doch de jonge Donders verzuimde niet in te halen wat hem, tot dan, aan kennis ontbrak. In vier jaar, de tijd waarbinnen de opleiding tot officier van gezondheid verliep, deed hij, die kennelijk over een fabelachtig bevattingsvermogen beschikte, ook zijn academische examens.

In Utrecht werd hem echter, gezien zijn vooropleiding, de toegang tot het doctoraalexamen geweigerd. Hierop preobeerde hij het in Leiden, waat men kennelijk coulanter was en keerde drie dagen later als doctorandus naar Utrecht terug. Zou hij met zijn Boxmeer's Latijn, dat hij "als water" sprak, de Leidse faculteit geimponeerd hebben?

Als militaire arts in Vlissingen en den Haag werkte hij ook aan zijn dissertatie die over menigitis handelde.

Misschien is het interessant te vermelden dat Donders in 1842 zijn academische carriere, als docent aan de Militaire Geneeskundige School, begon met een salaris van f. $800,--$ ! (Inderdaad per jaar). 
Doch keren wij terug naar Cornelis Adrianus. Zijn promotor (Heynsius) had in 1874, het jaar van zijn promotie te Leiden, zijn proefschrift zeer geprezen. Het werk was echter ook in Utrecht niet onopgemerkt gebleven en speciaal Donders had er zijn collegae opmerkzaam op gemaakt. Toen men daar aan de Rijks Veeartsenijschool in 1877 een opvolger zocht voor de docent fysiologie en pathologische anatomie, welke plaats tot dan vervuld werd door Dr. Th.H. MacGillavry, viel de keus op Pekelharing. ${ }^{20}$

Daar, zoals wij reeds schreven, de huisartsenparaktijk Pekelharing niet meer bevredigde, temeer daar zijn verantwoordelijkheid als arts tegenover ernstige patiënten hem psychisch zwaar drukte en zijn hart naar het experimenteren uitging nam hij de benoeming aan de veeartsenijschool aan. Voor het onderwijs was door de regering dus een fysioloog van professie uitgekozen, maar het was de bedoeling dat deze daarbij ook het onderwijs in de histologie, de algemene pathologie, de pathologische anatomie en de praktische mikroskopie voor zijn rekening zou nemen. De reus die dit alles op een schraal tractement moest presteren was Dir. Pekelharing. Hij werd in November 1877 benoemd.

Zoals we zagen, had de Veeartsenijkundige Hoogeschool toen

${ }^{20}$ De regering had de ontwikkeling van de Rijks-Veeartsenijschool meestal meer tegengewerkt dan bevórderd, waarbij bleek dat het belang van een geleerde en bekwame veeartsenijkundige stand vrijwel niet werd ingezien. Nadat Dr. Th.H. MacGillavry in 1872 directeur was geworden en het onderwijs bij de wet van 1874 financieel op een iets ruimere voet was geregeld, kwamen er onderwijsgebouwen en een nieuw internaat voor de studenten, die er in een vierjarige cursus werden opgeleid. Het onderwijs was schools en van opzet practisch gelijk aan dat op een middelbare school. Daar de toelatingseisen gering waren kon ook het propadeutisch niveau wan biologie, natuur- en scheikunde van nauwelijks voldoende gehalte zijn. Bij het lezen van de geschiedenis hierover krijgt men het gevoel, dat Thorbecke, die in 1851 Minister van Binnenlandse Zaken was en die $0 . a$. in het vaststellen van het leerprogram zeer eigenmachtig was opgetreden, er meer waarde aan hechtte dat veeartsen met boeren konden omgaan, dan dat zij zieke dieren konden genezen. 
Pekelharing zijn werkzaamheden op 1 januari 1878 te Utrecht begon, reeds een bewogen leven achter de rug. Dr. MacGillavry en de leraar Wirtz, vonden na 1872 bij de regering gehoor om de inrichting op een hoger peil te brengen. Na de reorganisatie werd Wirtz directeur. Dr. MacGillavry werd op 1 oktober 1877 tot hoogleraar in de pathologische anatomie in Leiden benoemd. Gezien de uitgebreide onderwijsopdracht van Pekelharing is het begrijpelijk dat er vrijwel geen tijd voor wetenschappelijk onderzoek over bleef. terwijl dit toch het lokaas was waarop hij de benoeming had aangenomen. Men krijgt echter de indruk dat hij nooit berouw van zijn benoeming heeft gehad, want hij kwam in Utrecht door zijn nieuwe functie in contact met mannen die in het wetenschappelijk en matschappelijk leven van die dagen vooraan stonden. Hij leerde Donders beter kennen en ook Herman Snellen ${ }^{21}$ de hoogleraar in de oogheelkunde, die zich ook de schoolhygiene en de volksgezondheid in Utrecht had aangetrokken.

Verder maakte hij kennis met de veelzijdig begaafde hoogleraar W. Koster ${ }^{22}$ die anatomie doceerde en voor wie hij altijd een bijzondere verering is blijven voelen.

Ook van de Afdeling Utrecht van de Ned. Mij tot Bevordering der Geneeskunst was hij al spoedig een gewaardeerd lid. (zie later). Pekelharing begon in Utrecht nu ook populair wetenschappelijke artikelen te schrijven en voordrachten te houden, wat bewijst dat hij al snel in het sociale circuit van de stad ${ }^{21}$ Herman Snellen werd 19 februari 1834 te Zeist geboren. Hij studeerde in Utrecht geneeskunde en promoveerde 4 juli 1857 over "De invloed der zenuwen op de ontsteking proefondervindelijk getoetst". De $17 \mathrm{e}$ november 1877 volgde zijn benoeming tot hoogleraar in de oogheelkunde te Utrecht. Op 27 oktober 1884 volgde hij Donders als Directeur van het Ooggasthuis op. In $1899 \mathrm{nam}$ hij ontsfiag als hoogleraar en volgde zijn oudste zoon hem op. Hij overleed in 1904.

22 Willem Koster werd op 24 oktober 1834 in Boskoop geboren. Hij studeerde in Leiden geneeskunde. In 1859 werd hij prosector bij Prof. Halbertsma en in 1862, na de dood van Schröder van der Kolk, hoogleraar in de anatomie, algemene pathologie, pathologische anatomie en gerechtelijke geneeskunde, aan de Utrechtse Hoogeschool. Hij nam 21 juni 1888 ontslag en overleed 7 juli 1907. 
werd opgenomen. Toch lukte het hem nog het onderzoek een gedeelte van zijn tijd te geven, vooral als er een belangrijke praktische aanleiding voor was. Onder de veestapel werden door het miltvuur vaak grote verwoestingen aangericht. Het onderzoek hilerover door Louis Pasteur en Robert Koch kreeg grote bekendheid en ook Pekelharing voelde zich hiertoe aangetrokken, zodat het al spoedig een onderwerp van studie en experimenteren voor hem werd. Voor de toen nog zeer jonge bacteriologie ging hij in de leer bij Prof. J. Cohnheim, een leerling van Virchow, die in Leipzig een laboratorium had. Hier heeft hij enige tijd gewerkt en leerde er o.a. hoe men met miltvuurcultures kon omgaan zonder er mee besmet te worden. In zijn verdere loopbaan als patholoog anatoom van dieren en later van de mens heeft hij het geluk gehad nooit door een wondinfectie te worden getroffen. Dit is te meer opmerkelijk daar toenmaals nog niet met handschoenen werd geseceerd.

\section{e. Hoogleraar aan de Medische faculteit der Rijksuniversiteit te Utrecht 1881-1918}

Toen in 1881 de medische faculteit hem als opvolger van de patholoog-anatoom G.J. Loncq ${ }^{23}$ wenste, wekte dat enige verbazing. Pekelharing was immers bekender als fysioloog en fysioligisch-chemicus, ja zelfs als bacterioloog, dan als patholoog anatoom.

Gedeeltelijk zal men op de stijgende renommee van Pekelharing zijn afgegaan, maar men moet ook niet vergeten dat Pekelharing tijdens zijn periode aan de veeartsenijkundige school bedrevenheid in het uitvoeren van secties verwierf. Het nieuws van de voordracht werd hem door Donders mede-

23- Gosewijn Jan Loncq werd op 10 december 1810 te Schiedam geboren. Hij kwam 1828 in Leiden aan als student en promoveerde op 16 december 1833 op een proefschrift getiteld "de Physiologia veterum". Op 20 april 1835 werd.hij lector in de gemeeskunde aan de Klinische School te Rotterdam en in 1840 hoogleraar in de medicijnen aan de Utrechtse Hoogeschool. Zijn emeritaat kreeg hij in 1881 en hij overleed op 21 juni 1887. 
gedeeld. Betrekkelijk snel, in juli 1881, volgde de benoeming tot hoogleraar in de algemene ziektekundige ontleedkunde. Pekelharing aanvaardde $z$ ijn nieuwe ambt met zijn inaugurale oratie op 21 september 1881. Zijn voorganger G.J. Loncq historicus, klinicus en verdienstelijk prakticus van de oude stempel, die wegens het bereiken van de 70-jarige leeftijd aftrad, liet geen bloeiend laboratorium na. Achter het Academisch Ziekenhuis, sedert 1871 in gebruik, was reeds voor Koster een sectielokaal met zeer klein laboratorium ingericht. Ook Talma ${ }^{24}$ heeft hierin gewerkt.

Voor Pekelharing werd in de tuin achter het ziekenhuis een nieuwe collegekamer met een ruimer laboratorium gebouwd. Een gelukkige omstandigheid was dat de toenemende welvart aan de regering de middelen verschafte om het hoger onderwijs te bevorderen. Het laboratorium van Pekelharing werd reeds in 1884 met een verdieping verhoogd. Hij kon nu over een paar werkkamers en een zitkamer beschikken zodat hij nu voldoende ruimte had voor zijn chemische proeven zowel als het mikroskopisch weefselonderzoek.

Pekelharing verrichtte voor Prof. Talma de klinische obducties. Hoewel hun leeropdrachten elkaar gedeeltelijk dekten, legde Talma het zwaartepunt op zijn klinische werkzaamheden terwijl Pekelharing de laboratoriumkant behartigde. Ook hadden zij vele gemeenschappelijke interesses. Zo was er het probleem van het gedrag der leucocyten bij ontsteking, een vraag waarin zij beiden groot belang stelden. Talma had als student in 1871 zijn antwoord op een prijsvraag hierover bekroond gezien.

24 Sape Talma werd in 1847 te Dokkum geboren. Hij studeerde geneeskunde in Utrecht, waar hij in 1873 tot doctor in de geneeskunde bevorderd werd na de verdediging van zijn proefschrift "Over licht en kleurperceptie". Donders was zijn leermeester en promotor. Hierna werd hij assistent aan de medische faculteit, later extraordinarius en uiteindelijk gewoon hoogleraar om onderwijs te geven in de algemene ziektekunde en de ziektekundige ontleedkunde en tevens de z.g. propadeutische kliniek aan het ziekbed te doceren. Hij schreef o.a. "Studien über Lungenschwindsucht" in 1879 en ook diverse artikelen in wetenschappelijke tijdschriften. Hij overleed in 1918. 
Pekelharing was bij het probleem nauw betrokken en het verschijnsel der diapedese had zijn bijzondere aandacht. Hiervan getuigen b.v. de dissertaties van J.A. Ruys en J.J. Scheltema. ${ }^{25}$ Voor de reeds genoemde vergroting van het laboratorium werd al spoedig gebruik gemaakt door Dr. C. Winkler, ${ }^{26}$ een leerling van Donders en Talma.

Winkler was huisarts in Utrecht, maar verkoos het wetenschappelijk onderzoek, net zoals Pekelharing in Leiden gedaan had. Ook hij werkte veel met het mikroskoop en interesseerde zich bijzonder voor zenuwziekten en psychiatrie. Tussen hem en Pekelharing ontstond al snel een samenwerking en vriendschap die hun hele leven is blijven bestaan. Over zijn kennismaking met Pekelharing schrijft Winkler als volgt.: Ik bracht hem in zijn laboratorium een bezoek en voelde mij onmiddellijk aangetrokken tot deze beminnelijke, uiterst zachtmoedige en toch strenge man. ${ }^{27}$

Zoals hiervoor beschreven had Pekelharing al een werkzaam aandeel genomen in het onderzoek over miltvuur, waarmede hij in Cohnheim's laboratorium had leren experimenteren. Omstreeks 1887 ontving de wetenschappelijke wereld daarvan bewijzen. Hij ontdekte het feit dat leucocyten zich actief bewegen naar de onbewegelijke miltvuurbacillen, om ze daarna in zich op te nemen. Het verschijnsel der phagocytose was reeds eerder, doch bij geheel andere organismen waargenomen door

2s Jac. A. Ruys. over de oorzaken van ettering. Acad. Proefschrift 1885 , Utrecht.

Jos J. Scheltema. Over iritatie van bindweefselcellen bij ontsteking. Acad. Proefschrift, 1886, Utrecht.

${ }^{26}$ Cornelis Winkler werd op 25 februari 1855 te Vianen geboren. Hij studeerde in Utrecht geneeskunde. Eerst werd hij assistent in het stadsziekenhuis in 's-Gravenhage. Na vervolgens huisarts in Utrecht geweest te zijn werd hij tot assistent en later tot lector in de psychiatrie te Utrecht benoemd. In 1886 en 1887 stelde hij met Pekelharing een onderzoek naar de oorzaak der beri-beri in Nederlands-Indie in. Hij overleed in 1940.

${ }^{27}$ Uit: "Herinneringen van Cornelis Winkler" 1855-1941. Van Loghem Slaterus. Arnhem, 1947. 
Prof. Elias Metschnikoff ${ }^{28}$ te Parijs in 1884.

Pekelharing bleef aan de leucocyten een grote betekenis toekennen voor de afweer van pathogene bacteriën. Hij publiceerde hierover in het Geneeskundig Blad "Over de functie van het lymphoide weefsel" en W.C. Mensonides promoveerde bij hem op een dissertatie die een direkt gevolg was van deze interesse "Over de invloed van actieve hyperaemie op de lymphstroom". Pekelharing bereidde zijn colleges altijd zorgvuldig voor. Hij zat vaak aan zijn bureau tot diep in de nacht te werken en dit kwam zijn gezondheid niet ten goede. In de zomer van 1885 ging hij met Winkler op reis naar een congres in Kopenhagen. Toen zij in Hamburg kwamen overviel hem daar een ernstige pleuritis. Hij keerde terug en herstelde. Hierna maakte hij met zijn vrouw een reis naar Zwitserland, waarvan zij eveneens in 1885 terugkeerden. In 1886 volgde zijn benoeming tot lid van de Koninklijke Academie van Wetenschappen. Op de vergaderingen der academie kwam hij in geregeld persoonlijk contact met onderzoekers buiten Utrecht. Hieruit resulteerde b.w. de vriendschap voor het leven met de bacterioloog Prof. M.W. Beijerink te Delft.

\section{f. Pekelharing en de beri-beri}

Sedert 1873 werden door de Nederlandse regering acties tegen Atjeh ondernomen. De militairen van land en zeemacht hadden hierbij veel te lijden van beri-beri. Scheube in Japan had er reeds op gewezen dat er bij de zieken een multipele ontaarding van de perifere zenuwen bestond, gepaard met spierverlamming vooral van de onderste extremiteiten, maar veel meer was er van de ziekte niet bekend. Koch's successen hadden gemaakt dat men bij het zoeken naar de oorzaak van een ziekte in de eerste plaats aan bacteriele infecties dacht. Een bezoek aan Koch leek dan ook een goed uitgangspunt voor een kruistocht tegen de beri-beri.

${ }^{28}$ Metschnikoff, E. Ueber eine Sprosspilzkrankheit der Daphnien Beitrag zur Lehre über den Kampf der Phagocyten gegen Krankheitserreger. Virchows Arch. path. Anat., 96 (1884) p. 177-195. 
Pekelharing werd aangezocht dit probleem op te lossen omdat hij hiervoor de meest angewezen geleerde was. In 1886 vertrok hij met Winkler, de zenuwarts, eerst naar Koch in Berlijn. In Berlijn maakten zij kennis met de officier van gezondheid in het N.I. leger Dr. Chr. Eykman, die daar in het laboratorium van Koch werkte. Bij zijn terugkeer naar Indië werd hij, tesamen met M.B. Romeny aan Pekelharing en Winkler toegevoegd.

Als voorbereiding had Winkler verschillende patiënten, die met de ziekte waren gerepatrieerd, onderzocht en een neuritis perifercia complexa gediagnosticeerd, zonder aandoening van het C.Z.S.

Op 9 januari 1886 vertrokken zij van Batavia naar Atjeh waar in een hospitaal een laboratorium werd ingericht. Voor het onderzoek waren hen negen maanden gegeven. Alle bacteriologisch onderzoek ten spijt werd slechts éênmaal een bacterie gevonden, die, bij een konijn ingespoten neuritisachtige verschijnselen veroorzaakte. Men keerde naar Batavia terug waar het onderzoek op konijnen en honden werd voortgezet, cavias bleken minder geschikt en van hoenders die later bij de oplossing van het beri-beri vraagstuk zo'n grote rol zouden spelen wordt in de verslagen niet gesproken. Het gelukte nu vrij regelmatig met uit het bloed van beri-berilijders gekweekte bacteriën, konijnen te infecteren. Pekelharing was overtuigd althans één verwekker te hebben gevonden, reden waarom hij adviseerde woningen, gebouwen en schepen te desinfecteren.

Ook vroeg hij de regering om in Weltevreden het "laboratorium tot het doen van onderzoekingen op het gebied der pathologische anatomie en der bacteriologie" te doen inrichten, hetgeen in 1887 gebeurde. Zowel uit het resultaat van het onderzoek als uit de naamgeving van het laboratorium ziet men hoezeer deze onderzoekers gespitst waren op het bacteriologisch onderzoek.

Tot directeur van dit laboratorium werd Dr. Eykman benoemd. De stichting van dit laboratorium dat later van zo grote betekenis zou worden voor het ontdekken van de ware oorzaak van de beri-beri, is zonder twijfel aan het initiatief en door- 
zettingsvermogen van Pekelharing te danken. Winkler keerde met hem in augustus 1887 naar Amsterdam terug waar zij in september aankwamen.

Het is ongetwijfeld de grote verdienste van Dr. Eykman samen met zijn collegae Grijns en Vordermans in de jaren na 1888 geweest, te hebben aangetoond dat voeding met gepolijste rijst bij hoenders polineuritis doet ontstaan, terwijl bruine rijst niet tot deze verschijnselen leidt en ze zelfs tegengaat. Dit leidde in 1898 tot de ontdekking van de anti-beri-beristof in het rijstevlies. Men mag Pekelharing geen verwijt maken dit zelf niet gevonden te hebben, zijn waarnemingen waren niet onjuist geweest, zijn conclusies erover wel.

Zijn tijdgenoten waren niet ontevreden. Zwaardemaker laat in een bespreking van het wetenschappelijk werk van Pekelharing de kwestie op elegante wijze in het midden. Hij zegt: C'est d̀ Pekelharing et Winkler que revient la tâche d'indiquer que cette polyneurite était réellement le point de départ de la maladie. La découverte accessoire de la présence régulière d'un micrococcus, qui dans l'Atchin et à Batavia pouvait également produire une neurite périphérique chez les animaux, les conduisit à proposer un certain système de défense contre la maladie, consistant en une évacuation et une desinfection des casernes. Ces mesures hygiéniques furent heureusement suivis d'une baisse notable dans la mortalité et dans le nombre des malades. Het onderzoek van Eykman werd door Pekelharing van uit Nederland nauwlettend gevolgd. Als hij de stof die Eykman gevonden had een vitamine genoemd had, of een andere algemeen aanvaarde naam gevonden had en het algemene principe van het belang van sporentoevoegingen aan de voeding, dat hij zeker gezien moet hebben, wat wijder had uitgedragen, was zijn naam ongetwijfeld alsnog van wereldformaat erkend. $\mathrm{Nu}$ definieerde Funk pas in 1912 de "vitamines" en in een later Amerikaans artikel leest men: $I t$ is to be regretted that Pekelharing refrained from publications. 
Pekelharing was behalve biochemicus ook fysioloog en histoloog. Aan de fysiologie werkte hij in zijn laboratorium met niet minder toewijding dan aan het zuiver scheikundig werk. Voor de weefselleer was M.J. van Erp-Taalman Kip en later W.J. de Wilde zijn assistent. Op het onderzoek naar $\mathrm{HCl}$ en pepsine afscheidende cellen van de maagklieren promoveerde W.R.H. Kranenburg.

In 1889 deed Pekelharing een histologisch-fysiologisch onderzoek met de zoöloog Vosmaer over de kraagcellen bij sponsen en het opnemen van voedsel door deze cellen. In 1902 schreef hij over het bindweefsel bij de oester op verzoek van Dr. P.C. Hoek. De bindweefselcellen bij deze dieren zijn een stapelplaats voor glycogeen. $\mathrm{Zij}$ vormen grote blazen waarin deze stof is opgehoopt. Zo ziet men een onvermoed raakpunt met één van de neveninteressen van Alexander Schmidt. Of Pekelharing de oester ook culinair wist te waarderen vermeldt de geschiedenis niet.

Pekellharings leerling W.C.M. Busch werkte over de localisatie van het glycogeen bij enige darmparasieten en schreef in 1905 hierover een dissertatie.

Zo animeerde Pekelharing verscheidene studenten om een histologisch onderwerp te bewerken en hierover een proefschrift te schrijven.

In 1905 (herdruk 1917) verscheen van hem voordrachten over weefselleer. Het was een enorm werkstuk, dat origineel Nederlands is en van de ontdekkingen op histologisch gebied een onpartijdig beeld geeft. In de recentie die M.C. Dekhuijsen er van geeft in het N.T.v.G., lezen we: wat het lezen van de verschillende hoofdstukken aangenaam maakt, is de historische zin van de schrijver, die niet alleen het hoe, maar ook het waarom in de geschiedenis van menig onderwerp verhaalt.

Een ander onderwerp dat zijn volle aandacht had was de samenstelling en betekenis van de vetten zowel fysiologisch als histologisch. In een artikel in zijn "Album der Natuur" van 1906 over de rol van het vetweefsel bij warmbloedige dieren beschrijft 
hij deze reeds zowel als isolerende laag en als voedseldepot. Het is duidelijk dat Pekelharing een wijde interesse had en vele gebieden heeft aangepakt. Hij was nog in de gelukkige omstandigheid dat hij veel onderzoek eigenhandig kon uitvoeren. De tijd dat Pekelharing zijn experimenten over de bloedstolling uitvoerde ligt in hoofdzaak tussen 1890 en 1915 .

Bij de meeste experimenten stond de technicus Kagenaar hem ter zijde. Pekelharing werd sterk aangetrokken door de werkwijze en de resultaten van de Russische fysioloog I.P. Pavlov, ${ }^{29}$ in combinatie met zijn chemische interesse leidde dit tot een onderzoek van de invloed van alcohol op de maagsapsecretie.

In 1901 vroeg hij de chirurg Prof.Dr. A. Narath een hond een maagfistel te geven. Hierna kon hij experimenteren over de invloed van aethylalcohol vóór of tijdens de maaltijd gegeven. De beschrijving van deze subtiele, zeer nauwkeurige experimenten vindt men in Onderzoekingen, gedaan in het Physiologisch Laboratorium der Utrechtse Hoogeschool 5e reeks 4 pag. 147 e.v. en in het Nederlandsch Tijdschrift voor Geneeskunde $38^{1}$, 1902 pag. 917 e.v. waar hij tot de volgende slotsom komt: Zo is er dus inderdaad een verklaring te geven van de oude gewoonte om den maaltijd met het gebruik van alcoholische dranken te verbinden. Ieder zal wel inzien dat deze verklaring niet gelijkgesteld mag worden met een verdediging. De gezonde mens heeft, als hem smakelijk voedsel in voldoende hoeveelheid ten dienste staat, waarlitk geen slcohol nodig om hem te helpen dat te verteren. Menigeen die zich na een dag van $z$ ware arbeid en velerlei zorgen aan tafel zet, kan zich gezond noemen en toch in den smaak van het voedsel alleen geen voldoenden prikkel vinden voor de cellen der maagklieren. Indien dan door een geringe hoeveelheid alcohol de digestie bevorderd en daardoor opgewekt wordt, is er, naar ik meen, geen reden om een glas wijn of bier niet als een heilzaam genees-

29 Ivan Petrovitsch Pavlov (1849-1936). Hij is ongetwijfeld een der grootste fysiologen aller tijden geweest. Zijn levensloop zowel als de hoofdlijnen van de ard en inhoud van zijn werk mogen bekend verondersteld worden. Hij werd in 1904 met de Nobelprijs onderscheiden. 
middel te beschouwen. Waar de grenzen gelegen zijn, moet beproefd worden, niet alleen voor ieder individu, maar voor dezelfde mens onder verschillende omstandigheden te bepalen. Tot zover Pekelharing.

Dit is weer een van de vele voorbeelden dat in die tijd, bij iemand die geinteresseerd was in de chemische kanten van de fysiologie, in de enzymen van de spijsvertering, in de bloedstolling etc. etc., de grens tussen fysiologie en chemie niet scherp te trekken is.

Het hoeft dan ook niet te verwonderen dat in het "fysiologisch laboratorium" van Donders, de "chemicus" Pekelharing toch op zijin plaats was.

Zowel in Utrecht als ook in Amsterdam, zoals blijkt uit de inrichting van de laboratoria, werd de chemische tak van de fysiologie nog nauwelijks als een onafhankelijke tak van de wetenschap gezien. Ook speelde er zich een strijd af, niet onvergelijkbaar van wat men later zag bij de interne geneeskunde en de chirurgie met hun subspecialismen; een onderddel van een groot vak ontwikkelt zich tot zelfstandigheid, en de meesters van de oude school verzetten zich daartegen.

In dit licht is het nog steeds de moeite waard kennis te nemen van het magistrale betoog, waarmede Eduard Pflüger in 1877 de kunstmatige scheiding van "die Eine grosse herrliche Wissenschaft der Physiologie" in een fysisch en een chemisch deel bestreed. Hij mocht betogen: Die Natur und ihr Thaten sind unendlich, aber die allgemeinen Gesetze werden mit dem Fortschreiten der Wissenschaft immer einfacher werden und indem wir uns in diesen stützen, wollen wir der immer weiter gehenden Zersplitterung der Einzelfächer uns entgegen stemmen, da ja die Einzelheit nur in der Allgemeinheit ihren wahren Wert erlangt.

De ontwikkeling in tegengestelde zin was echter niet meer te stuiten. Eigenlijk woedde de strijd in Utrecht, min of meer verdekt, al heel lang. Zonder dat men van een openlijke vete kan spreken is het toch duidelijk dat de chemicus G.J. Mulder ${ }^{30}$

${ }^{30}$ Gerardus Johannes Mulder werd op 27 december 1802 te Utrecht 118 
en de fysioloog Donders ieder hun eigen opvattingen hadden over de fysiologische chemie.

De scherpzinnige en felle Mulder bepleitte geregeld de onafhankelijkheid van de fysiologische chemie. De geweldenaar Donders hield de zaken liever in één hand, althans in één laboratorium onder één directeur.

En zo bleef het; ook toen Pekelharing, leerling van Heynsius, die zelf weer een leerling van Mulder was, in Utrecht de fysiologische chemie onder zijn hoede kreeg.

geboren. Hij studeerde daar geneeskunde en pharmacie. In 1825 vestigde hij zich in Amsterdam als arts, werd vervolgens leraar in de natuurkunde bij het Bataafse Genootschap (1826), daarna leraar in de plantkunde en scheikunde aan de klinische school in Rotterdam (1827).

In 1841 werd hij door de Groninger Academie honoris causa tot doctor in de wis- en natuurkunde bevorderd. Hij schreef o.a. "proe" ve eener algemeene physiologische scheikunde" in 1843, dat ook in het Duits en Engels werd vertaald. "'t Streven der stof naar harmonie" in 1844, "de Elementen" in 1845. In 1847 "De voeding in Nederland in verband met de volksgeest"; in 1848 "Berzelius herdacht " en hetzelfde jaar ook "Verval van Nederland, Bezuiniging, onderwijs". In 1849 publiceerde hij "Wetenschap en Volksgeluk" en "De weg der Wetenschap zijnen leerlingen opnieuw aanbevolen". Hij redigeerde met Van Hall en Vrolijk van 1826 tot 1832 de "Bijdragen tot de natuurkundige wetenschap" met Wenkembach van 1836 tot 1838 het "Natuur en scheikundig archief".

In 1841 werd hij te Utrecht tot hoogleraar in de scheikunde benoemd. In 1841 stichtte hij met Miquel en Wenkenbach het "Bulletin des sciences physiques et naturelles en Neerlande". Van 1842 tot 1868 publiceerde hij zijn "Scheikundige onderzoekingen gedaan in "t Laboratorium van de Utrechtsche Hoogeschool".

In 1868 beëindigde hij zijn professoraat en vestigde zich in Bennekom, waar hij, nadat hij blind was geworden, op 18 april 1880 overleed. $\mathrm{Na}$ zijn dood verschemen, nog van hemzelf zijn "Levensschets van G.J. Mulder", dat later door zijn vrienden werd uitgegeven. De bijdrage waardoor G.J. Mulder tot op de dag van vandaag in de fysiologische chemie doorleeft is de "ontdekking" althans het definieren van de proteinen, waarmede hij voor praktisch de gehele wereld (maar niet voor Nederland!!) een naam gaf aan het belangrijkste studieobject van de biochemie. 


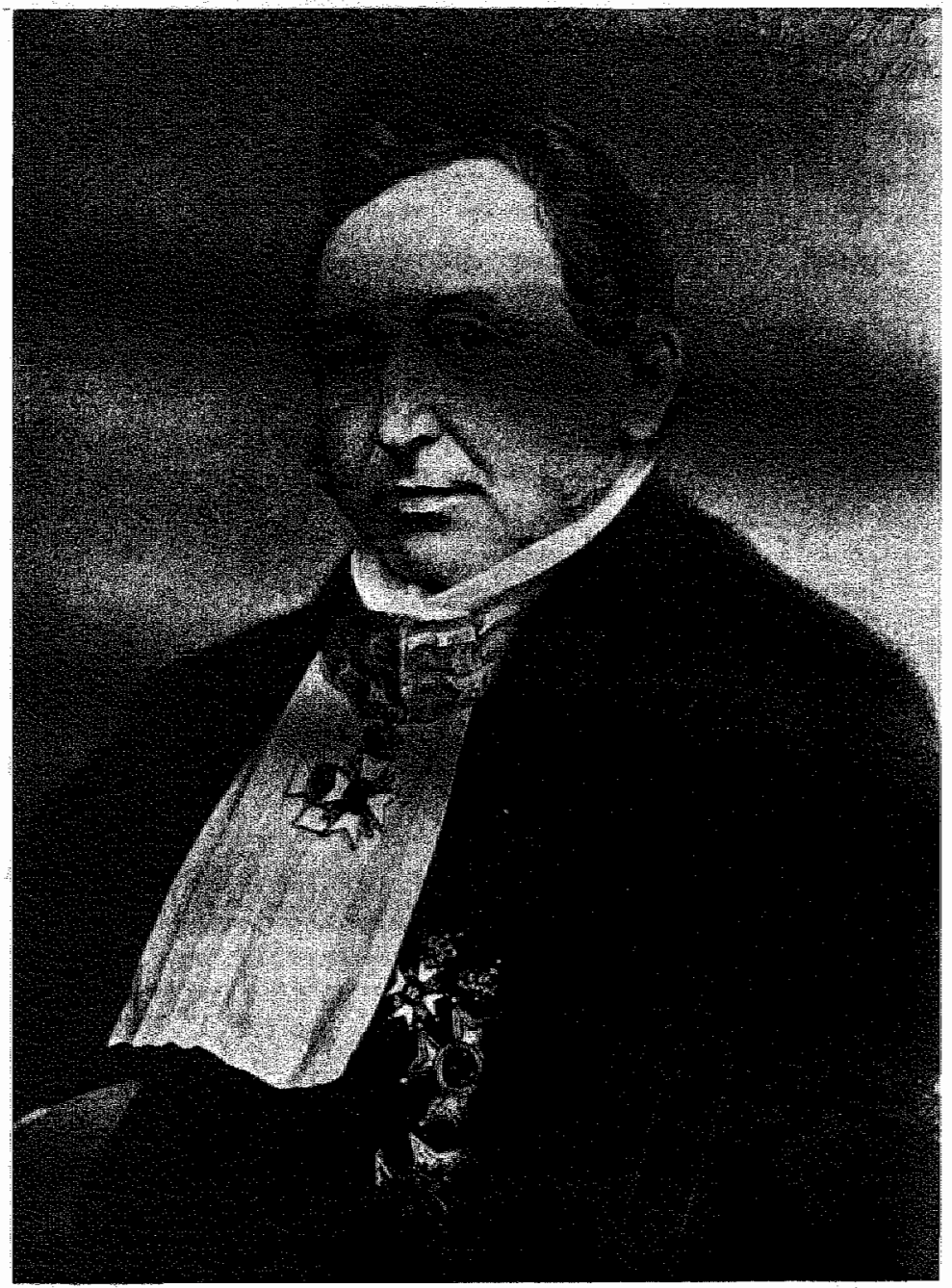

Afb. 17: Gerrit Jan Mulder (18-2-1880) 
h. Pekelharing, de medische opleiding en de maatschappij der geneeskunst.

De medische opleiding heeft altijd een dualistisch karakter gehad. Ze is altijd een compromis geweest tussen een beroepsopleiding en een wetenschappelijke studie. Tot 1798 was zij voor een belangrijk gedeelte in de handen van het chirurgijnsgilde. In de loop van de $19 \mathrm{e}$ eeuw werd zij tot een volledig academische studie, echter niet zonder dat de niet academische beroepsbeoefenaren een belangrijke rol bleven spelen. Via het Organiek Kon. Besluit van 2 augustus 1815 waarbij het Hoger Onderwijs in de Noordelijke Provincies werd geregeld en de discussies die rond 1850 over de medische opleiding in het Parlement plaatsvonden, kwamen tenslotte op 1 juni 1865, tijdens het 2e Ministerie van Thorbecke, de geneeskundige wetten tot stand die o.a. de "eenheid van stand" regelden.

Pekelharing interesseerde zich hiervoor bijzonder. Het maatschappelijk leven voor zover zich dit in ons land afspeelde had zijn belangstelling, maar de gezondheidszorg in het algemeen, de geneeskundige verzorging en zoals we reeds zagen de artsenopleiding in het bijzonder gingen hem zeer ter harte. Hij was beslist niet de wereldvreemde laboratoriumgeleerde waarvoor velen hem aanzagen.

Van het handhaven der oude wetgeving waren vooral de plattelandsbewoners en de minder goed gesitueerden het slachtoffer. Zo was b.v. het geneeskundig "toevoorzicht" ten enemale onvoldoende door o.a. de traagheid waarmee het werkte. Bij de arme en plattelandsdokters was er weinig neiging tot na en bijscholing of intercollegiale toetsing. ${ }^{31}$

${ }^{31}$ Hierover zegt J.P. Heye in:

Archief voor Geneeskunde Dr. J.P. Heye, 2 e dr. 1842 onder "Inlandsche journalen": De Commissiën voor Gk.O. en Toevoorzicht maken bij ons het hoofdmiddel uit waarvan zich de Staat, ter handhaving van den openbaren gezondheidstoestand bedient. De Plaatselijke Commissiën (Wet van 12 maart 1818 en Besluit van 31 mei 1818) hebben te waken woor de handhaving van alle algemeene 
Wij moeten hier niet aan onwil denken, maar veeleer aan de onvoorstelbaar moeilijke omstandigheden. Het gebrekkig vervoer, de beperkte opname en consultatiemogelijkheden, de grote en zeer verscheiden pathologie die zich voordeed, alles verleende aan een armenpraktijk een hectisch karakter, waarvan vaak de dokter zelf, maar in ieder geval zijn nascholing de dupe werd. De hierboven geschetste omstandigheden waren er de oorzaak van dat besprekingen en discussies waardoor één en ander verbeterd zou kunnen worden, te weinig plaatsvonden.

In 1844 was in Zutphen een geneeskundige kring opgericht en vản deze kring ging de oproep, aan alle geneeskundigen in Nederland, uit, om zich landelijk te verenigen, mede met het doel zeggenschap in de opleiding te behouden en om na- en bijscholing mogelijk te maken. Dit loffelijk streven had pas na vijf jaar succes. Tenslotte kwam na veel briefwisseling en vergaderen, in 1849 de "Nederlandsche Maatschappij tot bevor-

en plaatselijke Verordeningen omtrent het uitoefenen van alle tak. ken der Geneeskunde. Over het nadere van deze Commissiën spreekt de wet niet. $\mathrm{Zij}$ zullen in iedere stad, waar vier of meer Medic. of Chir. Doctoren gevestigd zijn, kunnen opgericht worden. Behalve hare vroeger genoemde bestemming, zullen zij, bij het ontstaan van besmettelijke ziekten, aan de Stedelijke Regering de noodige maatregelen voorslaan; zij dienen der Provinciale Commissiën van berigt, consideratiën en advijs, visiteren de winkels van Apotheken en Drogisten en geven er der Prov. Comm. rapport van.

Voor het overige mogen zij geene nieuwe Reglementen aan de Sted. Reg. aanbieden, dan onder goedkeuring der Prov. Comm.

De taak van de Prov. Comm. bestond o. a. uit:

1. Onderzoek naar bekwaamheid of bevoegdheid van hen die eenige tak van Geneeskunst in Prov. of District gingen uitoefenen.

2. In het geven van getuigschriften van bekwaamheid aan allen die binnen Prov. en District tot Stads, Plattelands of Scheepsheelmeester, Vroeḍmeester, Apotheker, Vroedvrouw, Oogmeester, Tandmeester en Drogist of Kruidenverkopers wenschen bevorderd te worden.

3. In het Toevoorzicht op de "rigtige en goede" uitoefening van de praktijk der Geneesk. Wetenschap door reeds gevestigden, en op al degene, hetwelk de gezondheid in het algemeen aanbelangt. 
dering der Geneeskunde" tot stand. De eerste algemene vergadering hiervan vond plaats in 1849 te Arnhem, onder voorzitterschap van Dr. Voorhelm Schneevoogt. Zeer zeker kwamen ook, mede onder auspiciën van deze Maatschappij, de meergenoemde geneeskundige wetten onder Thorbecke tot stand. Weliswaar was nu de eenheid van o.a. de bevoegdheid der geneeskundigen vastgelegd, maar de oplossing van het vraagstuk van de opleiding zou nog jaren op zich doen wachten. Als we al moeten aannemen dat het heden ten dage is opgelost.

In 1851 taande de algemene belangstelling en de samenwerking wan de praktizerende artsen en er werden verschillende afdelingen van de N.M.t.b.d.G. opgeheven. Van de hoogleraren der Universiteiten ging echter altijd een stimulerende impuls uit, ook het Atheneum te Amsterdam liet zich in deze niet onbetuigd, vooral de verhoging van het wetenschappelijk peil had hun interesse. In juli 1885 werd Pekelharing als candidaat van de Afdeling Utrecht tot hoofdbestuurslid gekozen. Na zijn terugkomst uit Indië in 1887 werd hij in het volgende jaar tot Voorzitter van het Hoofdbestuur gekozen en in deze kwaliteit sprak hij Donders toe bij diens huldiging aan het eind van zijin 70e levensjaar.

Reeds in 1885 was hij rapporteur van een door de Maatschappij ingestelde commissie die een betere regeling van de artsenexamens moest voorbereiden. In 1894 werd hij weer tot hoofdbestuurder en in $1896 \mathrm{nog}$ eens tot voorzitter van de Maatschappij gekozen. In hetzelfde jaar hield hij in juli voor de algemene vergadering der Maatschappij een merkwaardige openingsrede. Zijn schoonzoon Prof. Dr. J.M. Baart de la Faille die in 1912 met zijn dochter. Mathilda is gehuwd, beschrijft deze als volgt: Hij begon met het houden van een warm pleidooi voor de fysiologie. De pathologische anatomie moge onder de invloed van Virchow de geneeskunde zeer veel hebben vooruitgebracht, de leer der pathologische verrichtingen der organen is er het natuurlijk gevolg van en daar ligt nog een nieuw veld van onderzoek, dat toch zeer de belangstelling der praktizerende artsen verdient.

Het waarnemen der ziekteverschijnselen bij de patiënten is niet 
voldoende, op hun interpretatie volgens de leer der fysiologie komt het aan. De therapie moet daarop berusten. En bij dat alles krijgt de chemie een steeds groter betekenis.

De geneesheer moet profijt trekken van hetgeen de fysiologie aan het licht brengt. Diens opleiding moet ook in dit deel der wetenschap behartigt worden waardoor zijn verdere belangstelling in de vooruitgang wordt gewekt. De Regering is thans in dit opzicht nalatig tegenover de student in de geneeskunde. En indien de volksvertegenwoordiging verzuimt haar te wijzen op de achterstand bij het hoger onderwijs, zoals blijkt uit haar stilzwijgen bij het ontslag van de hoogleraar in de psychiatrie te Utrecht, Prof. $C$. Winkler, dan is het de algemene vergadering der Maatschappij, volgens Gerrit Jan Mulder de Staten Speciaal, die haar stem moet laten horen.

En tensiotte de aanmaning aan zijn toehoorders: De geneeskunst heeft yoortdurend steun te zoeken bij de natuurwetenschap.

De periode van Pekelharing in het Hoofdbestuur viel samen met de tijd van tweespalt in de Maatschappij. Door uitbreiding van het ziekenfondswezen rond 1890, werd de maatschappelijke positie van de artsen enigszins onzeker geacht. Hiertegen werd geageerd door o.a. Dr. C.F. Schreve, opdat niet de voordelen der verwachtte verzekeringswetten, die rond 1895 ingevoerd waren, ten behoeve van de arbeiders, de arts zijn zelfstandigheid tegenover zijn fondspatiënten zou doen verliezen, ten nadele van de geneeskundige behandeling.

Sommige leden der Maatschappij wilden haar in 1897 in een vakvereniging omzetten, anderen daarentegen wilden dat niet en men rekende op Pekelharing om de krisis te bezweren. Hij genoot groot vertrouwen bij de verschillende stromingen, zodat tenslotte overeenstemming werd bereikt over het behoud der Maatschappij.

Over zijn werk in de Maatschappij ten slotte nog dit:

Toen Pekelharing op 21 september 1906 zijn 25 jarig jubileum in alle stilte vierde, had de algemene vergadering hem tevoren tot erelid benoemd, waarbij hij een fraaie oorkonde ontving, die verklaarde: bij het 25 jarig hoogleraarschap van Professor 
Pekelharing in dankbare herinnering te brengen, wat deze, niet het minst in de laatste jaren bij de reorganisatie der Maatschappij, in haar belang heeft gedaan.

\section{i. Omstreeks de eeuwwisseling en later}

De $3 e$ november 1897 trof Pekelharing een zware slag door het overlijden van zijn vrouw. Hij is dit verlies nooit geheel te boven gekomen hoewel zijn dochters, inmiddels 16 en 19 jaar oud, zich jarenlang inspanden de gastvrije traditie in het huis aan de Maliestraat voort te zetten.

Zijn oudste zoon was in het jaar 1887 cum laude bij Prof. Hamaker gepromoveerd in de rechtswetenschappen. (Proefschr.: "Terugvordering van vermogens vermeerdering zonder oorzaak naar Nederlandsch recht") en zijn tweede zoon was in hetzelfde jaar als chemicus naar Ned. Indië vertrokken. De 21e september 1906 was Pekelharing 25 jaar hoogleraar. Van de grootse huldiging, die gedeeltelijk door de Ned. Mij tot bev. der Geneeskunst was voorbereid, wilde hij niet weten. Door Jan Veth werd van hem een protret geschilderd, dat in de bibliotheek van het nieuwe Pathologisch Instituut werd geplaatst.

Hij was nu 58 jaar en de steun die hij van zijn steeds wisselende tijdelijke assistenten ontving bij onderwijs en onderzoek werd hem onvoldoende. Daarom drong hij er bij Curatoren op aan te worden bijgestaan door twee bekwame krachten in volledige dienst, een voor de chemie en een voor de histologie. Ondanks de karige bezoldiging die zij hiervoor ontvingen, werden Dr. E.W. Ringer voor de chemie en Mej. M.A. van Herwerden voor de histologie bereid gevonden als zijn permanente assistenten op te treden.

In september 1908 begonnen zij aan hun taak, die zij tot het eind van Pekelharing's activiteiten, zeer tot zijn genoegen, zijn blijven vervullen.

Eveneens in 1908 reisde hij naar Stockholm en Upsala, waar hij tot zijn grote spijt zijn vriend Hammarsten ${ }^{32}$ misliep.

${ }^{32}$ Olof Hammarsten werd op 21 augustus 1841 geboren. Hij studeer- 
In de winter van 1910 werd zijn gezondheid minder goed. Hiervoor deed hij in het voorjaar een rustkuur op het eiland Wight.

$\mathrm{Zijn}$ jongste dochter trouwde in 1912 . Hiermee verliet de vrouw des huizes zijn woning. Dit veroorzaakte grote verandering in zijn dagelijks leven waarin hij zich echter opgewekt schikte. In 1913 huwde zijn tweede zoon, die uit Ned. Indië was teruggekomen wegens een tropische ziekte, maar geheel herstelde. Van zijn jongste zoon, die botanicus was op Java en die in 1908 was gepromoveerd, kreeg hij een invitatie hem te komen bezoeken. Hij vond het bijzonder prettig weer eens naar Nederlands Indië te kunnen gaan, maar toen hij daar in Augustus 1914 aankwam was de oorlog in Europa begonnen. Hij is daarop spoedig teruggereisd en toen hij in september aankwam, was onze neutraliteit en het behoud daarvan, het vraagstuk waarover ieder zich zorgen maakte.

Pekelharing had zich altijd afzijdig gehouden van de practische politiek in ons land. Hij woelde zich niet tot de confessionele partijen aangetrokken doch behoorde ook niet tot de kleurlozen doch in feite tot een gematigde tussen-groep ter linkerzijde. Hij voelde sterk nationaal en de Duitsers hadden zijn sympathie niet. Belgische studenten die in Amersfoort geinterneerd waren, hielp hij bij hun studie. In de oorlogsjaren ging het medisch onderwijs aan de Nederlandse studenten inmiddels, voor zover mogelijk gewoon door. Hoewel hij na de oorlog, bij het ouder worden zich op verschillende gebieden moest ontzien, bleef hij de raadsman van de leidende figuren van medisch onderwijs en onderzoek. Pekelharing was nu 37 jaar hoogleraar en de dag van zijn afscheid naderde. Hij hield zijn afscheidsrede in overleg met Curatoren, in het groot auditorium te Utrecht op 14 juni 1918. In deze rede hield hij een fel pleidooi voor de snelgroeiende betekenis van de chemie voor de geneeskunde,

de in Upsala en werd aldaar in 1883 tot hoogleraar in de medische en fysiologische chemie benoemd. Hij publiceerde veel artikelen op het gebied van de biochemie, doch is het meest bekend geworden door zijn onderzoekingen op het gebied van de bloedstolling en haemostase. Hij overleed in 1932. Zie verder hoofdstuk III. 
verdedigde zijn overgang van de pathologie naar de fysiologie en schetste de functie van de weefselleer, door het bestuderen van de vorm functioneel te maken als onderdeel van de kennis van het gedrag der weefsels. Na afloop hield hij een drukbezochte receptie in het Universiteitsgebouw en had 's avonds een diner met zijn familie en enkele vrienden. Ook op de $19 \mathrm{e}$ juli, de dag van zijn 70 e verjaardag, werd dit laatste nog eens herhaald.

Ook werd hem op die dag door de collegae Zwaardemaker, Einthoven, wan Rijnberk en Hamburger hoogleraren in de fysiologie te resp. Utrecht, Leiden, Amsterdam en Groningen een "Livre jubilaire" van het Archives Neerlandaises de physiologie de l'homme et des animaux en l'honneur de C.A. Pekelharing aangeboden. Het werd geopend met een artikel van $\mathrm{Z}$ waardemaker: 'l'Oeuvre de C.A. Pekelharing jusqu'à son septuagénaire". Verder bevat het artikelen van o.a. Bayliss, Gunzberg, Hammarsten, Hedin en Fano. In september 1918 vermeldt de Series lectionum dat Pekelharing op 18 september, "rude donatus" was geworden. Doch op 20 september deed hij weer van zich horen bij de huldiging van zijn vriend Winkler die zijn 25 jarig jubilleum als hoogleraar in de psychiatrie te Utrecht herdacht. $\mathrm{Na}$ het sluiten van de vrede in 1918 voerde hij correspondentie met verschillende vakgenoten in het buitenland en ontving hij sommige bij hem thuis.

$\mathrm{Hij}$ heeft in de vier jaren die hem nog restten o.a. op verzoek van Prof. Beyerink in Delft "Some remarks on enzymes" (Rec. Trav. Botan. Néerland. 16, 1919, p. 207 e.v.) geschreven. Hierin zet hij zijn mening uiteen over het tot stand komen van biologische processen onder de invloed van organische katalysatoren. (zie ook het vorige hoofdstuk).

Op 22 juni 1922 beklom hij voor de laatste maal het catheder in het groot auditorium der Universiteit van Utrecht ter gelegenheid van de onthulling van het standbeeld van Donders, dat o.a. in tegenwoordigheid van de ministers van O.K. en W. en van Arbeid, aan het gemeentebestuur van Utrecht werd overgedragen.

De 19 e juli 1922 vierde hij met zijn kinderen voor de laatste 
maal zijn verjaardag. In de namiddag van de $18 \mathrm{e}$ september kwam de Senaat in rouwzitting bijeen. Pekelharing's beste vriend Winkler schetste zijn levensloop en verdiensten als geleerde. Bij de begrafenis, die op 21 september platsvond, voerde namens de Senaat en de Medische Faculteit nogmaals Winkler als eerste het woord in een treffende rede. Een reeks van sprekers roemden $z i j n$ grote wetenschappelijke verdiensten, zijn voortreffelijk onderwijs en zijn waardevolle leiding bij de aanvang van hun zelfstandig onderzoek. Samen gaven ze een duidelijk beeld van wat Pekelharing, voor hen die het voorrecht hadden hem te kennen persoonlijk en voor mens en maatschappij, had betekend.

Pekelharing's werk beslaat de laatste twee decennia van de negentiende en de eerste twee van de twintigste eeuw. De communicatie was ook toen nog en zeker vergeleken met de mogelijkheden die ons ten dienste staan, tamelijk gebrekkig.

In vele opzichten was het een overgangstijd, waarin men met de kennis die men nu heeft, duidelijk de moderne geneeskunde zijn schaduw vooruit ziet werpen. Men leze b.v. Pekelharing's herhaalde pleidooien voor een grote rol van de chemie in de geneeskunde.

De begaafdheid en zin voor wetenschap was bij Pekelharing en zijn tijdgenoten beslist niet minder dan bij degenen die hun vooraf gingen of na hun kwamen. Maar hun vondsten waren meermalen zo nieuw dat zij soms zelf het belang ervan niet inzagen en dikwijls niet verder konden omdat de techniek nog te weinig ontwikkeld was. Ook hier nemen we een golfbeweging waar. De bio-chemici uit die tijd waren vaak te zelfbewust. Dat er wel eens een meer subtiele chemie zou kunnen bestaan dan die waarvan zij zich bedienden, drong slechts zeer langzaam door. Men had nog heel weinig besef van hetgeen niet in grammen gewogen en geanalyseerd kon worden. Als wij ons dat realiseren, dan realiseren we ons ook wat een fundamentele verschuivingen in het denkpatroon de dageraad van de enzymchemie met zich meebracht en kunnen we grote bewondering opbrengen voor mannen als Pekelharing die daar een belangrijke rol bij speelden, ook al is hun eigen originele 
bijdrage in het licht van wat wij nu weten gering te noemen. Daarom ook is het een dankbare taak voor een bioloog en amateurbiograaf de ontdekking die zo iemand wél deed en die welhaast vergeten leek te worden weer eens voor het voetlicht te halen. 


\section{APPENDIX A}

....prenez intérèt, je vous en conjure, à ces demeures sacrées que l'on désigne du nom expressif de LABORATOIRES.

Demandez qu'on les multiplie et qu'on les orne: ce sont les temples de l'avenir, de la richesse et du bien-être.

C'est là que l'humanité grandit, se fortifie et devient meilleure.

Quelques réflexions sur la science en France. Louis Pasteur. 1868

Paris, 1871, Gauthier-Villars, brochure de $40 \mathrm{p}$. in $-8^{\circ}$. 


\section{DE HUIDIGE OPVATTINGEN OVER DE THROMBINE- VORMING}

\section{Thrombine}

Thrombine is een proteolytisch enzym van de serine-proteasen familie. Het toont enige gelijkenis met trypsine in zijn specificiteit voor bindingen naast arginine. Het bestaat uit een $A$ en B keten die door een disulfidebrug verbonden zijn. De Bketen bevat het actieve serine en toont uitgebreide gelijkenis met trypsine, chymotrypsine, elastase en ook met andere proteasen uit de bloedstolling. Magnusson heeft de primaire structuur van beide ketens opgelost. De functie van de A-keten is nog onduidelijk, hij is waarschijnlijk gedeeltelijk verantwoordelijk voor de opvalllende specificiteit van het enzym; het grote fibrinogeenmolecuul ( $M=360.000)$ bevat vele potentieel kwetsbare bindingen naast arginine maar toch worden er slechts twee door thrombine gesplitst. Hierdoor worden de fibrinopeptiden $A$ en $B$ van resp. de $\alpha$ en de $\beta$ keten van het fibrinogeen afgesplitst en ontstaat het fibrinemonomeer dat spontaan polymeriseert.

Hiernaast activeert thrombine factor XIII, de fibrinestabiliserende factor, die in het fibrinepolymeer covalente bindingen aanlegt. Ook factor $V$ en factor VIII worden door thrombine in actieve vorm omgezet, waardoor de thrombine de eigen vorming in een positief feedback systeem bevordert.

Er bestaat ook een negatieve feedback, omdat thrombine prothrombine splitst in een product, dat veel minder snel geaktiveerd kan worden dan intact prothrombine.

De derde, en misschien belangrijkste rol van thrombine is die op de thrombocyten. Thrombine induceert aggregatie van thrombocyten en maakt de plaatjesfosfolipiden beschikbaar voor het stollingsproces, een andere vorm van positieve feedback. Naast een thrombinevormend, is er ook een efficiënt antithrombinesysteem aanwezig in het plasma, waarvan de be- 
langrijkste component antithrombine III is. Dit eiwit bindt thrombine, waarbij een product wordt gevormd zonder enzymatische activiteit.

Prothrombine. De rol van Vitamine $\mathbf{K}$

Prothrombine is het zymogeen van thrombine, een molecuul met een enkelvoudige keten van 586 aminozuurresiduen; het molecuulgewicht is 72.000 en het bevat zowel de A- als de Bketen van thrombine, maar deze vormen slechts ongeveer de helft van het molecuul, omdat er een ongewoon groot activeringspeptide aanwezig is. (zie figuur 1).

Voor de vorming van thrombine dient de aminozuurketen van het prothrombine op twee plaatsen te worden gesplitst. In het activeringspeptide zit een voor thrombine kwetsbare plaats, waardoor het peptide kan worden gesplitst in fragment 1 en fragment 2 . Het fragment 1 gedeelte van prothrombine bindt aan fosfolipide, het fragment 2 gedeelte aan factor $V$. Deze bindingen zijn van grote betekenis voor de activatie. Voor de binding van het fragment 1 gedeelte, het zgn. Nterminale eind van prothrombine is het nodig, dat 10 glutaminezuurresiduen worden omgezet in $\gamma$-carboxyglutaminezuren. Deze carboxylatie vindt plaats in de lever en vereist vitamine $\mathrm{K}, \mathrm{O}_{2}$ en $\mathrm{CO}_{2}$. Bij een tekort aan vitamine $\mathrm{K}$ door deficiëntie of door toedoening van vitamine $K$ antagonisten komt bij de mens decarboxyprothrombine in de circulatie, dat ook bekend staat als PIVKA II (protein induced by vitamin $\mathrm{K}$ absence). PIVKA II kan langzaam geaktiveerd worden waarbij thrombine ontstaat. In bepaalde laboratoriumtesten, zoals bijv. duidelijk bij de Thrombotest ${ }^{(}$werkt PIVKA remmend. Dit fenomeen leidde indertijd tot de ontdekking van PIVKA. Aangezien PIVKA II identiek is met prothrombine m.u.v. de capaciteit om aan fosfolipiden te binden vormt het een ideaal model om de invloed van de fosfolipiden binding van factor II te bestuderen.

Analoog met factor II worden ook andere vitamine $\mathrm{K}$-afhan- 
kelijke factoren gecarboxyleerd en bij onvoldoende vitamine $K$ verschijnen PIVKA VII, PIVKA IX en PIVKA $X$ in de circulatie.

\section{Prothrombinase}

De bindingen, die in prothrombine moeten worden verbroken, teneinde thrombine te vormen, kunnen worden gesplitst door verschillende proteolytische enzymen. Geaktiveerde $F$ X (F Xa) is de natuurlijke activator, maar andere enzymen (trypsine, bepaalde slangengiffen) doen het ook. Deze reacties kunnen in vrije oplossingen plaatsvinden, maar zijn dan niet erg efficiënt. Onder fysiologische omstandigheden is er, specifiek voor $\mathrm{F} \mathrm{Xa}$, een veel effectiever mechanisme werkzaam.

De fysiologische activator van prothrombine bestaat uit F Xa gebonden aan een fosfolipidenoppervlak naast een molecuul $\mathrm{F} \mathrm{Va.} \mathrm{(zie} \mathrm{figuur} \mathrm{2).}$

$F \mathrm{Xa}$ is de geaktiveerde vorm van $\mathrm{F} X$, een van de vitamine $K$ afhankelijke stollingsfactoren. Deze factor bestaat uit twee eiwitketens. De zware keten $(M=44.000)$ bevat het actieve serine en is door middel van een disulfidebrug verbonden met de lichte keten $(M=17.000)$, welke $12 \gamma$ - carboxyglutaminezuurresiduen bevat in zijn $\mathrm{N}$-terminale ceel. In tegenstelling dus tot thrombine bevat dit geaktiveerde enzym $\gamma$-carboxyglutaminezuren, hierdoor $k$ an het binden aan fosfolipiden. Als dit enzym naast prothrombine aan het negatief geladen fosfolipide oppervlak adsorbeert, verloopt de thrombinevormming veel efficiënter dan wanneer de moleculen elkaar in vrije oplossing ontmoeten.

F Va is een eiwit, met een mol. gewicht van 145.000 , bestaande uit twee ketens, dat ontstaat uit een eiwit met een enkelvoudige keten $(M=360.000)$. Deze ketens worden verbonden door een $\mathrm{Ca}++$ ion. 
Dit is de reden, dat sterke Cat+-binders (bijv. EDTA) F V inactiveren. Onder fysiologische omstandigheden vindt de activatie plaats d.m.v. thrombine. $F$ Va heeft geen eigen enzymatische activiteit, maar versterkt de katalytische werking van $F$ Xa. Het fungeert dus als een cofactor en wordt ook wel paraenzym genoemd. Het prothrombinase wordt gevormd door reversibele adsorptie van de factoren $\mathrm{Va}$ en $\mathrm{Xa}$ op het fosfolipiden-oppervlak. Een vergelijkbare vorm van aktivatie vindt men ook twee maal bij de aktivering van $\mathrm{F} \mathrm{X}$ en op diverse plaatsen in het complementsysteem.

\section{De intrinsieke aktivatie van $F \mathbf{X}$.}

Het enzym, dat $\mathrm{F} X$ aktiveert is het vitamine $\mathrm{K}$-afhankelijke F IXa. F IXà heeft voor een optimale werking eveneens een negatief geladen fosfolipidenoppervlak en een paraenzym, in dit geval F VIII, nodig. F VIII wordt, net als F V, geaktiveerd door thrombine. F IXa ontstaat op zijn beurt uit F IX in een reactie, die wordt gekatalyseerd door F XIa.

De vorming van F XIa is een direct gevolg van contact van bloed met negatieve hydrofiele oppervlakken. (Hier dus geen fosfolipiden). In aanwezigheid van zo'n oppervlak wordt F XII geadsorbeerd vanuit het plasma, waardoor het een conformatieverandering ondergaat, die het een geschikt substraat maakt voor kallikreine. Kallikreine is in plasma gebonden aan "high molecular weight kininogen" (HMWK).

HMWK bevat een histidine rijk gebied, dat een positieve lading heeft. Hierdoor kan kallikreine dus indirect worden geadsorbeerd aan een negatief oppervlak en het daar aanwezige F XII activeren. Omgekeerd kan F XIIa weer prekallikreine activeren, dat zoals bovengenoemd via HMWK geadsorbeerd wordt. De vraag is dan natuurlijk: wat precies doet het proces beginnen? Momenteel denken we dat proënzymen niet volledig inactief zijn maar zelf reeds enige enzymactiviteit vertonen. Een wederzijdse activatie kan, als zij langzaam verloopt, zoals in normaal plasma misschien het geval is, gemakkelijk worden 
onderdrukt door de overvloedig in plasma aanwezige proteasenremmers. De binding aan het negatieve oppervlak maakt F XII niet alleen een beter substraat voor kallikreine maar veroorzaakt ook locaal een hoge concentratie van de reactiecomponenten. Hierdoor ontstaat een niet lineair verlopend proces, dat door de bescherming van de remmers heen breekt. F XIIa activeert F XI, dat net zoals (pre)kallikreine via HMWK aan het negatieve oppervlak gebonden is. De aktivatie via F XII, XI etc. staat bekend als het intrinsieke systeem; omdat er geen stoffen aan te pas komen van buiten het bloed, behalve dan het negatief geladen hydrofiele oppervlak.

\section{De extrinsieke activatie van F X.}

Naast de intrinsieke activatie van $\mathrm{F} X$ kent men het extrinsieke systeem. Bijna alle cellen bevatten weefselthromboplastine, dat kan complexeren met de vitamine $\mathrm{K}$-afhankelijke stollingsfactor VII. Dit complex kan F X activeren. F Xa kan op zijn beurt F VII activeren, hetgeen weer een versterkende wisselwerking geeft.

Het wordt steeds duidelijker, dat het extrinsieke en intrinsieke systeem niet onafhankelijk functioneren. Zo is het bekend, dat F VII met weefselthromboplastine F IX kan activeren. In situaties, waarbij weinig weefselthromboplastine aanwezig is, wordt de werking van $F$ VII op F X duidelijk versterkt door toevoegen van de factoren VIII en IX, maar onafhankelijk van de contactfactoren XII en XI. Dit verklaart waarom haemofilie $A$ en $B$ (een aangeboren tekort van resp. F VIII en F IX) gepaard gaan met een ernstige bloedingsneiging.

\section{Een stollingsbeperkend mechanisme.}

Protein $\mathrm{C}$ is een vitamine $\mathrm{K}$-afhankelijk plasma-eiwit, dat door thrombine wordt omgezet in een eiwitsplitsend enzym. Dit enzym heeft echter niet een stollingsbevorderende werking 
maar remt de voortgang van het stollingsproces juist. Het beschikt over $\gamma$-carboxyglutaminezuren en adsorbeert via Ca++ aan fosfolipidenoppervlakken. Als het daar het eveneens geadsorbeerde F V en F VIII ontmoet, breekt het deze af tot nietfunctionele polipeptiden. Dit is weer een voorbeeld van negatieve terugkoppeling in de bloedstolling.

De rol wan de bloedplaatjes in de stolling.

In fysiologische omstandigheden voorzien de bloedplaatjes in de fosfolipiden, nodig voor de stollingsreacties. Zwaal heeft aangetoond, dat de buitenkant van de plasmamembraan van de thrombocyt geen significante stollingsbeworderende eigenschappen bezit, de binnenkant daarentegen wel: met name het fosfatidylserine (PS) is essentieel omdat het een negatief geladen oppervlak levert, nodig voor de binding van de vitamine $\mathrm{K}$-afhankelijke factoren. Dit fosfatidylserine komt practisch alleen voor aan de binnenzijde van de plasmamembraam van de thrombocyt. Wanneer thrombocyten worden geactiveerd door de combinatie collageen/thrombine komt een deel van de binnenkant van de plasmamembraan ter beschikking aan de buitenkant (het zgn. "flip-flop-model"). Hierbij worden de thrombocyten niet afgebroken, hetgeen men kan meten omdat er geen intracellulaire enzymen in het reactiemedium terecht komen. Wel wordt de zgn. "release reaction" in gang gezet, waarbij materiaal vrijkomt uit de granulae van de thrombocyten, zoals serotonine, ADP en F V. Flip-flop en F V release samen verklaren ook de specifieke $\mathrm{Xa}$ bindingsplaatsen die ontstaan op het oppervlak van geactiveerde thrombocyten.

\section{Thrombine en Thrombose.}

Thrombine is het centrale enzym in de haemostase en bij het ontstaan van thrombose. De studie van de thrombinevorming 
is derhalve van groot belang voor de vele ziektebeelden waarbij haemostase en thrombose een rol spelen. Er is de laatste tijd tevens in toenemende mate bewijs aangevoerd, dat (micro-) thrombose niet alleen een belangrijke complicatie van artherosclerose is, maar ook een roll, mogelijk zelfs een belangrijke, speelt bij de pathogenese van atherosclerose.

Dat bloed stolt onder invloed van thrombine, dat thrombine een fibrinogeenoplossing omzet in een soort gel, is het meest indrukwekkende fenomeen dat thrombine bewerkstelligt in vitro, maar in vivo is het waarschijnlijk minder belangrijk. Sinds de jaren ' 60 is het duidelijk geworden, dat de thrombocyten een belangrijke rol spelen in de processen haemostase en thrombose. Aanvankelijk deed dit de rol van thrombine minder naar voren komen. Recent is het steeds duidelijker geworden, dat juist thrombine een van de belangrijkste prikkels is waardoor thrombocyten bij deze processen betrokken raken. Thrombine is echter niet de enige effector voor deze cellen. Prostaglandines, ADP, serotonine etc. spelen alle een rol. Thrombine echter maakt de plaatjesreactie irreversibel en is ook een goede kandidaat voor de eerste en belangrijkste plaatjesactivator. Het is derhalve niet langer te verdedigen, dat thrombinevorming uitsluitend een rol zou spelen bij de veneuze thrombose.

\section{Litera tuur}

1. De Bloedstolling, thrombose, atherosclerose en het hartinfarkt. Een uitgave van Natuur en Techniek, augustus 1979.

2. H.C. Hemker 1981. Vorming en functie van thrombine. Nederlands rijdschrift voor Geneeskunde. (in druk)

3. Jackson, C.M., Suttie, J.W. 1977. Physiol. Rev. 57, 1-70.

4. Griffin, J.H. 1979. Seminars in Thromb. and Haem. 5, 254-273.

5. Zwaal, R.F.A. 1978. Biochem. Biophys. Acta 515, 163-205. 


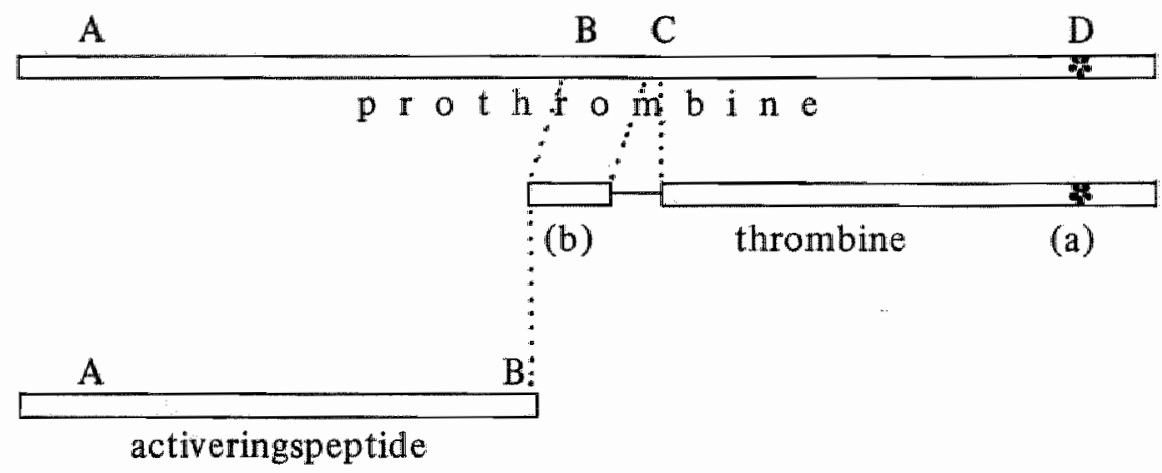

Fig. 1. Een "stokmodel" van het prothrombine

Het molekuul is in ontvouwen toestand weergegeven met het $\mathrm{NH}_{2}$-terminale einde links. Bij A bevinden zich de $\gamma$-carboxygutaminezuren die o.i.v. vitamine $\mathrm{K}$ worden ingebouwd; bij $\mathrm{D}$ het aktieve serine. Bij $\mathrm{B}$ en bij $\mathrm{C}$ zijn de plaatsen waar het prothrombinemolekuul geknipt moet worden om thrombine te laten ontstaan. De twee delen van het thrombinemolekuul blijven verbonden door een cystinebrug. 


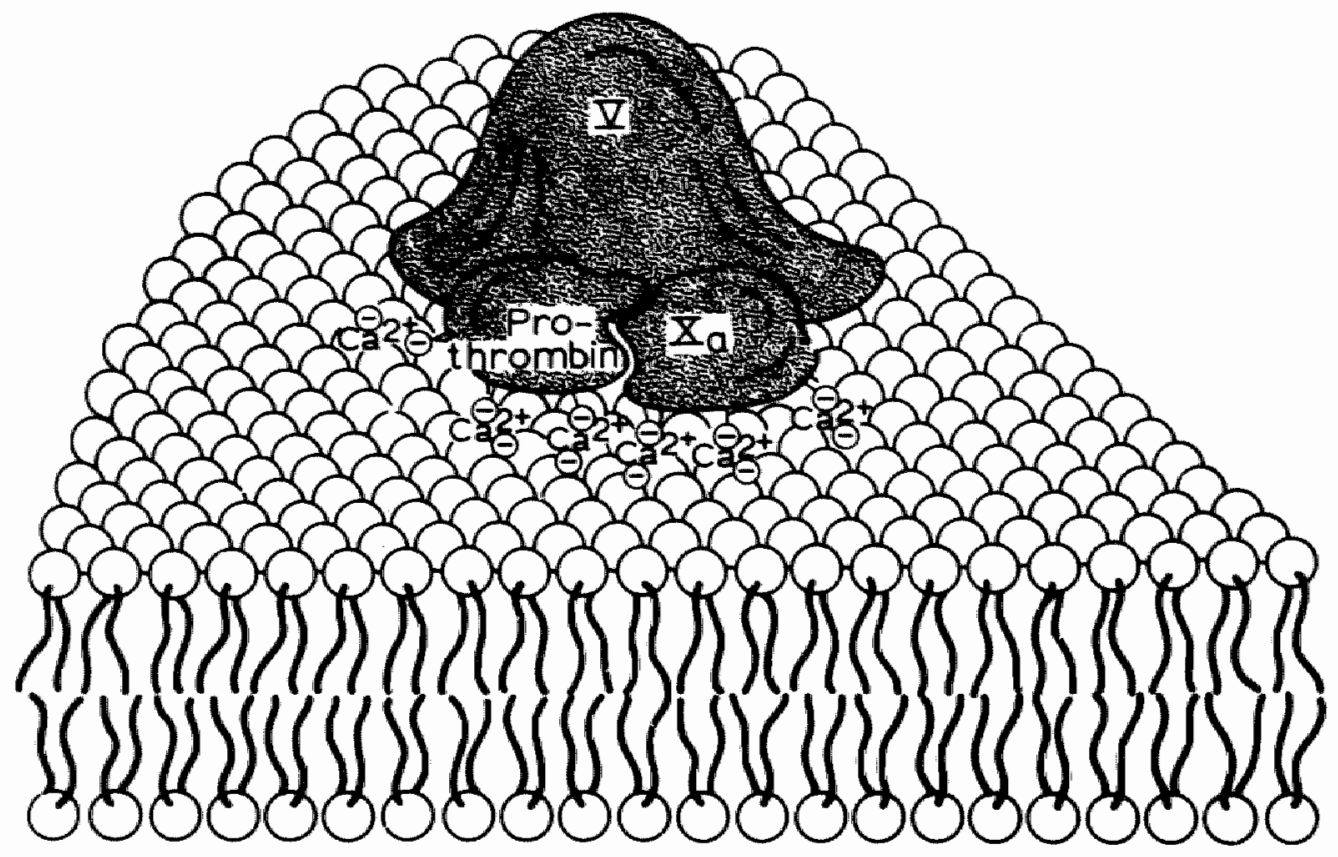

Fig. 2. Het prothombinase komplex.

Op een fosfolipide dubbellaag, waarin de polaire koppen door cirkeltjes zijn aangegeven en de vetzuurstaarten door streepjes absorberen het prothrombine en factor $\mathrm{X}_{\mathrm{a}}$ via $\mathrm{Ca}^{++}$ionen en factor $\mathrm{V}$ door hydrofobe binding. Alleen in deze configuratie kan thrombine snel worden gevormd. 
APPENDIX B

143 


\section{BIBLIOGRAFIE}

De vroege literatuur over de bloedstolling en hemostase is zeer verspreid en soms moeilijk toegankelijk. Wie een indruk wil krijgen van de ontwikkeling van de kennis op dit gebied is verplicht tot vrij uitgebreide speurtochten in bibliotheken in binnen- en buitenland.

Om dergelijk werk voor eventuele later geinteresseerden te vergemakkelijken heb $\mathbf{i k}$ een vrij uitgebreide bibliografie en een fotocopiearchief aangelegd.

Beide maken geen aanspraak op volledigheid. Schattenderwijs is 80 à $90 \%$ van de relevante originele stukken erin te vinden. De bibliografie bestaat uit drie afdelingen.

I De dissertatie van Schröder van der Kolk is integraal overgenomen.

II De bibliografie van Pekelharing is integraal overgenomen.

III De eigenlijke literatuurlijst van de in dit proefschrift behandelde artikelen is het derde deel.

Een asterisk bij de betreffende referentie geeft steeds aan of een copie van het betreffende artikel in ons archief aanwezig is. 


\section{$\mathbb{D} \mathbb{S} \mathbb{S} \mathbb{R} \mathbb{R} \mathbb{I} \mathbb{I} O$ PHYSIOLOGICO - MEDICA I N A U G UR A L I S,}

S I S E N S

SANGUINIS COAGULANTIS HISTORIAM, CUM EXPERIMENTIS AD EAM ILLUSTRAN. DAM INSTITUTIS:

Q U A M

FAVENTE SUMMO NUMINE

EX A UCTORITATE RECTORIS MAGNIFICT

C OR NEL I I DE W A A ,

A. I. M. Phil. et J. U. Doct, in Facultate Philofophiae Theoreticac et Literarum Humaniorum Prof. Ordinariti,

E $T$

CONSENTIENTE FACULTATE MEDICA $P \cap O G \Pi A D U D O C T O A A T U S$ SUMTISQUE IN MIDLICINA HONOIIBUS RITE LEGITIME CONSEQUENDIS IN CUOROTEMPLI ACADEMICI PUBLICO AC SOLEMNR FXAMINI OFFERT JACOBUS TUDOVICUS CONRADUS SCHROEDER VAN DER KOLK,

LEO ad dicm xvir Junii mibccix. Il ora xi.

$$
\text { G RONINGAE }
$$

Apul W. vaN BOLKLIREN, Bibliopolam. 

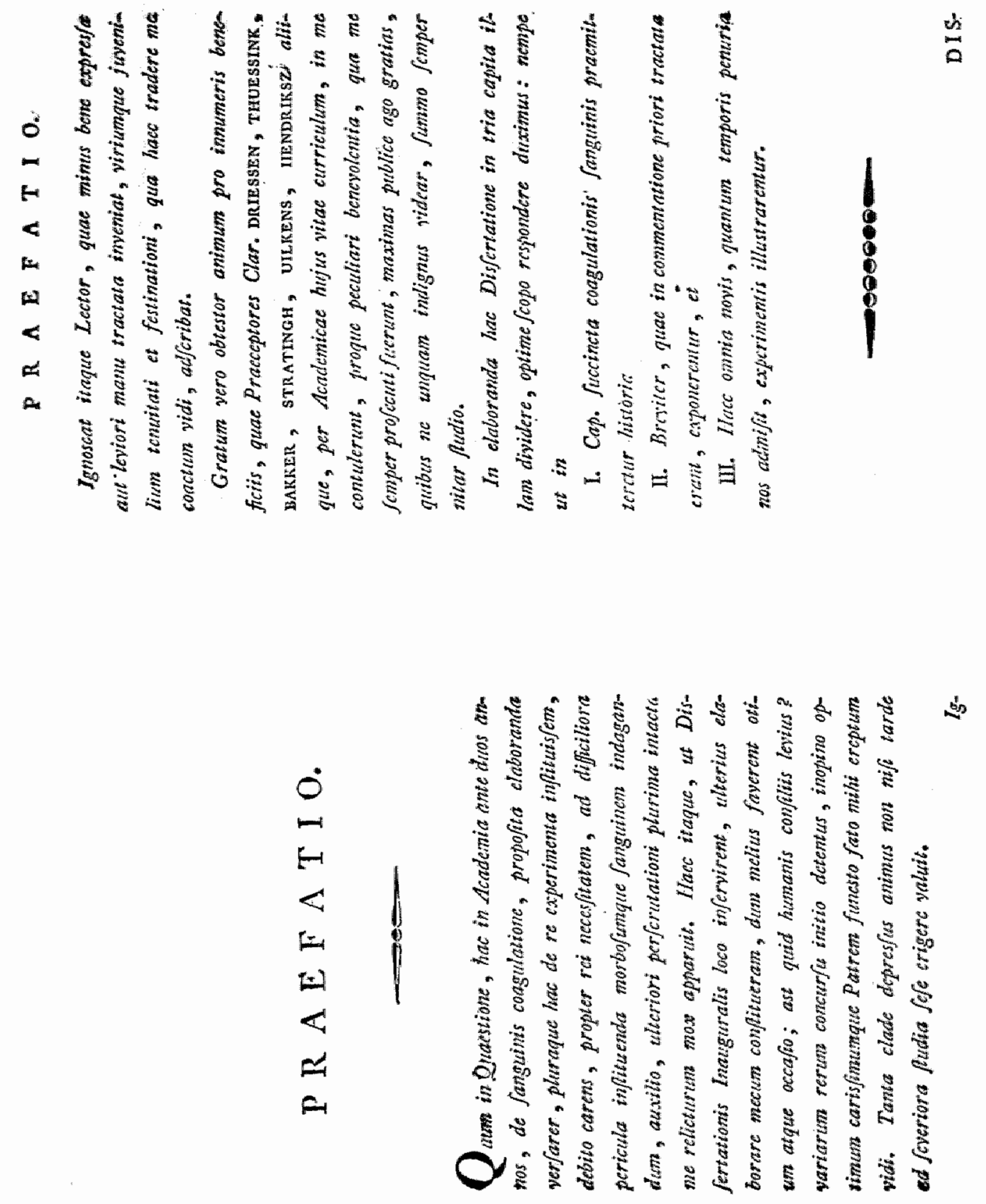


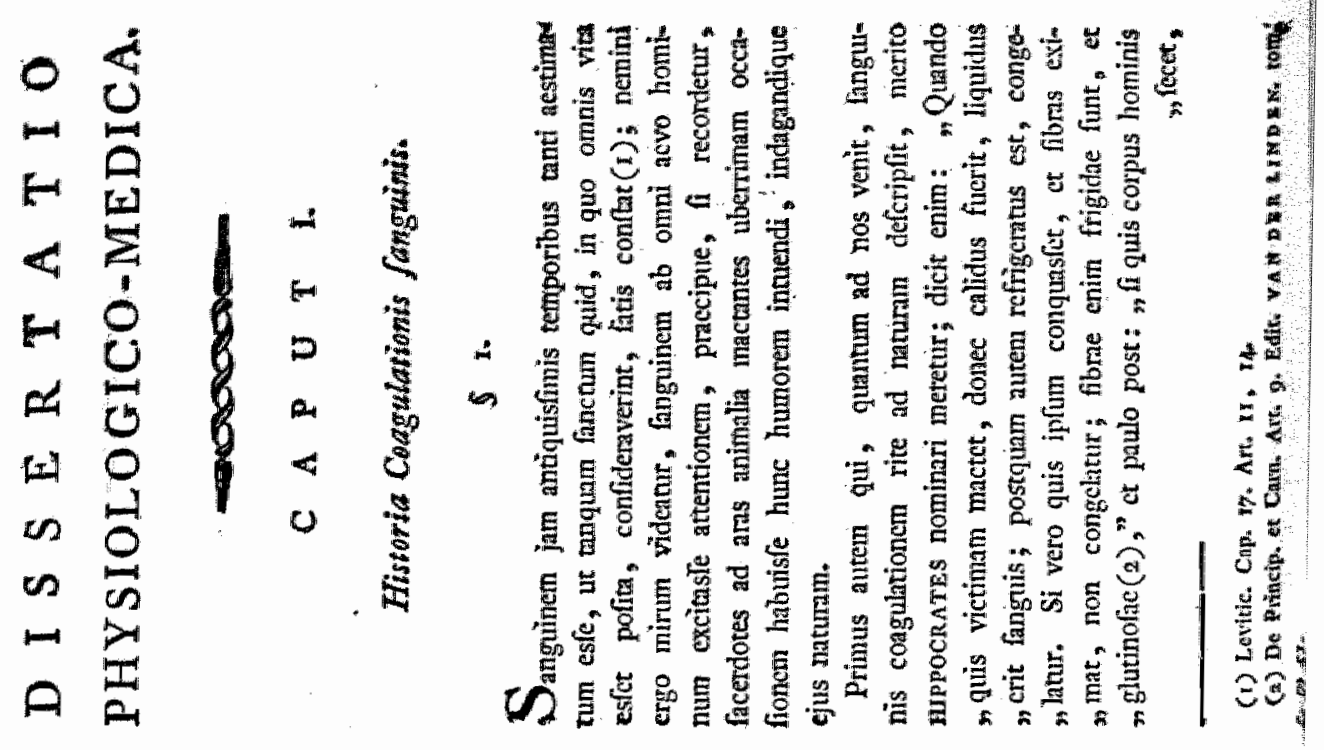




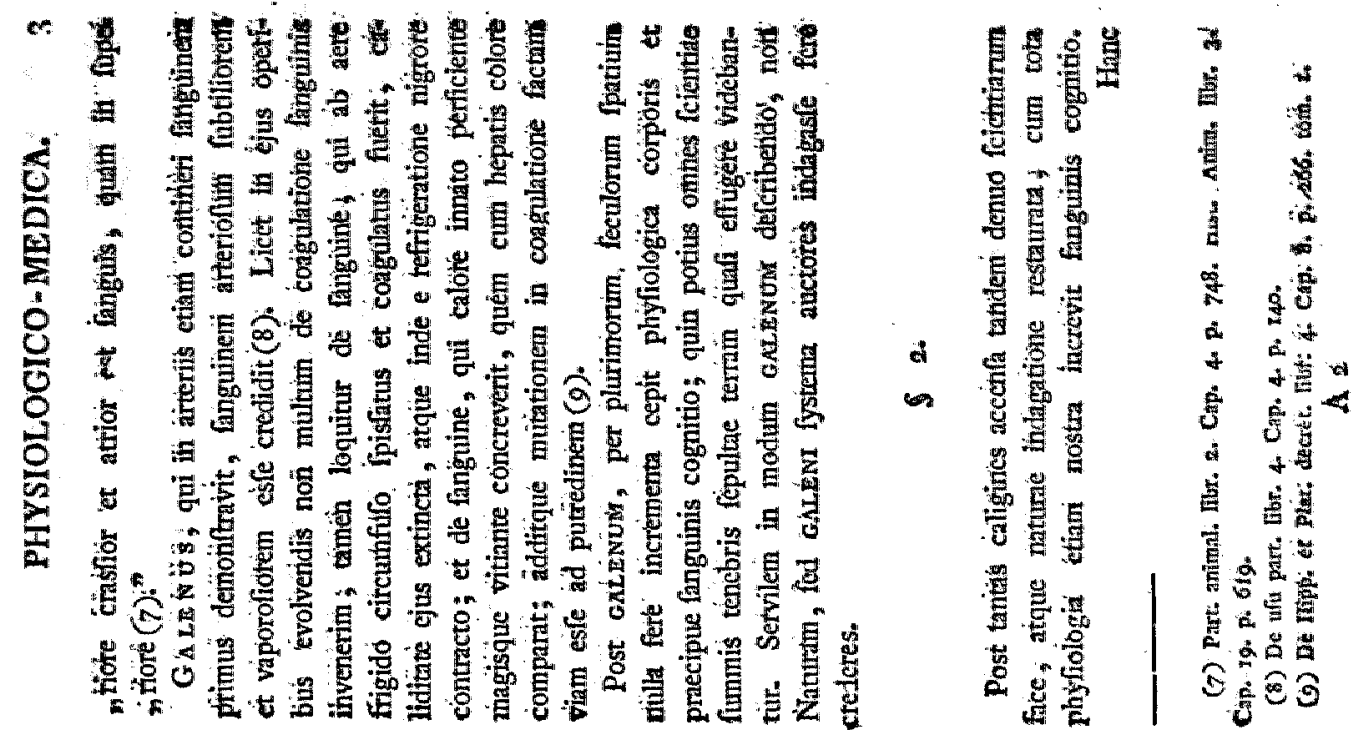

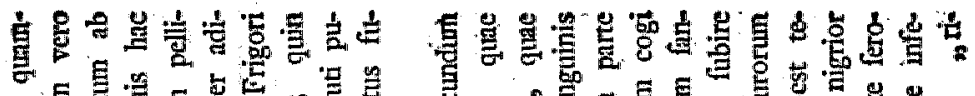

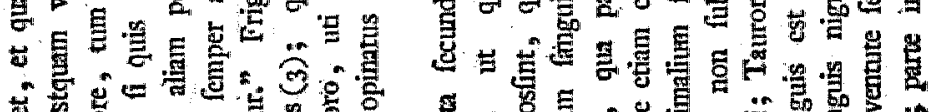

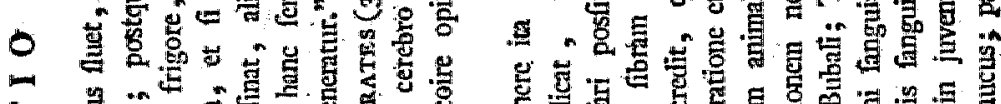

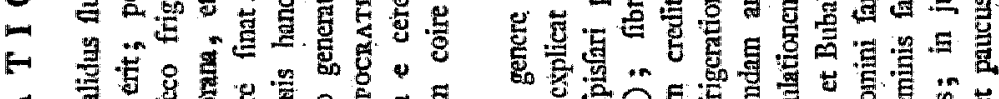
4 为

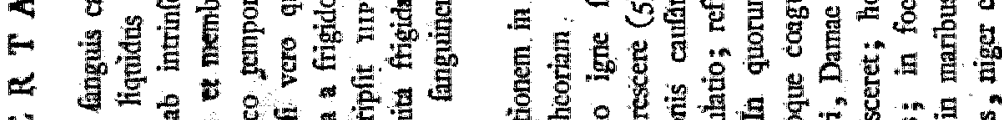
in

西

A

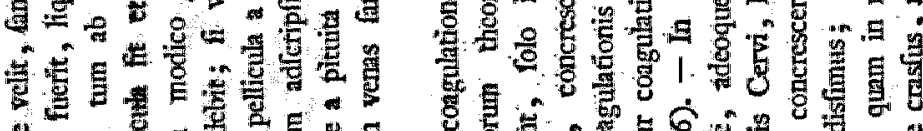

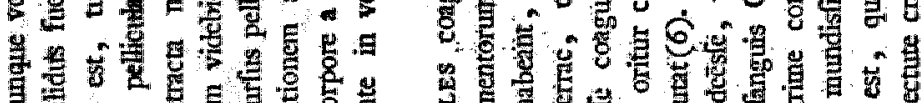

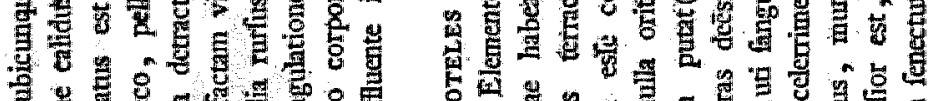

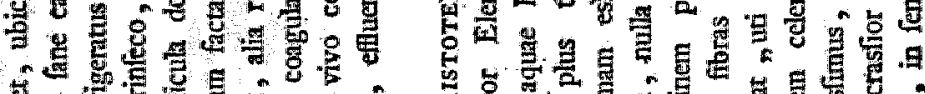

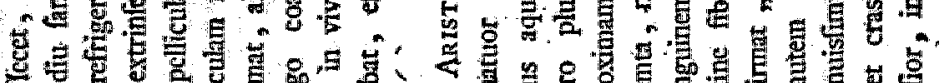

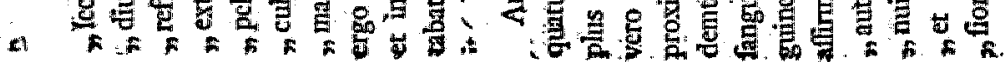

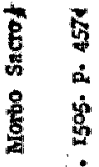

$\div$ व

密藏

น. 귬

基藏

s is

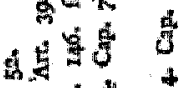

it $+4+$

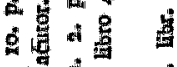

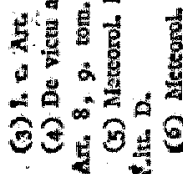


н.

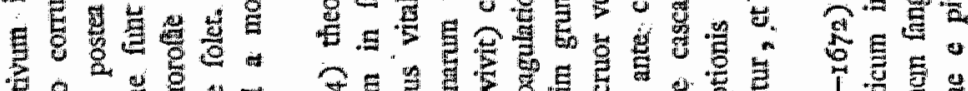

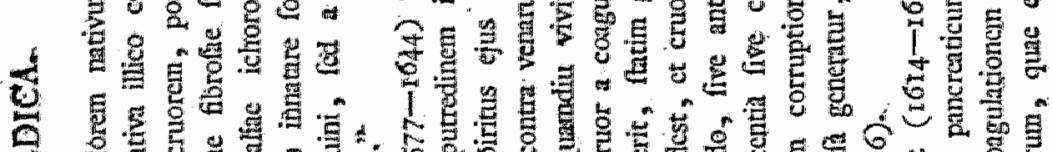

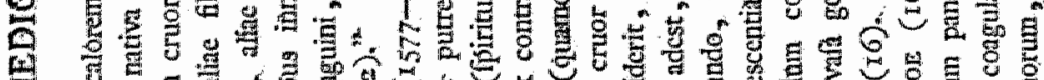

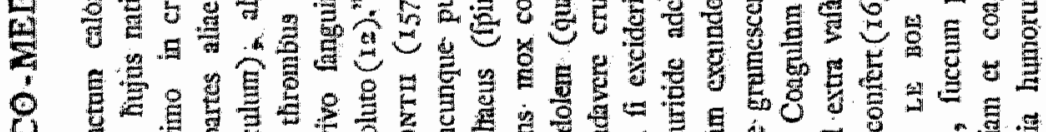

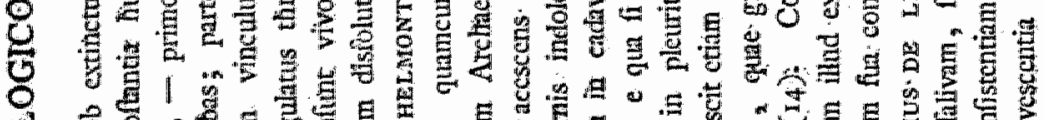

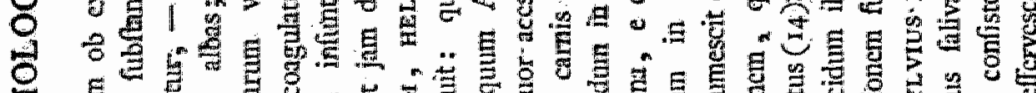

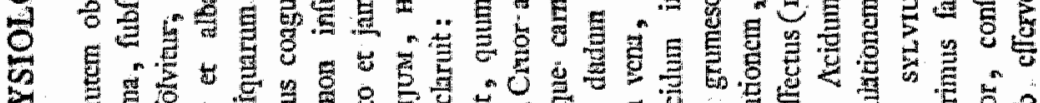

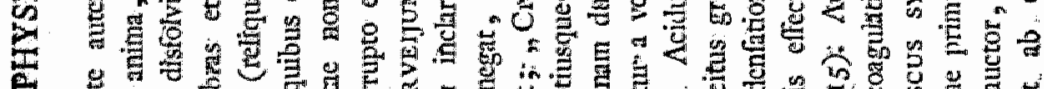
总.

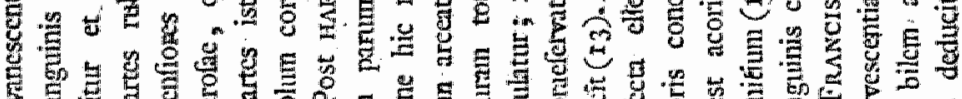

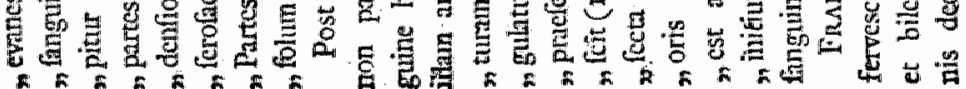

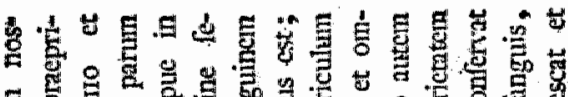

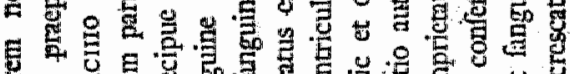

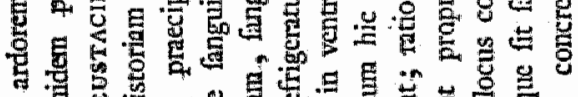

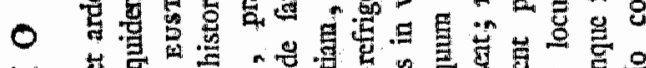

- 40

—

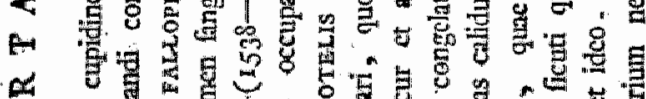

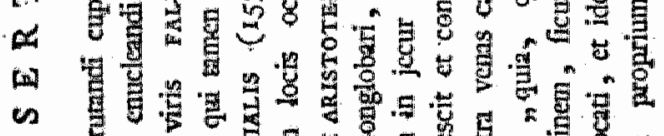

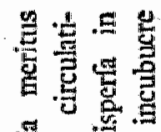

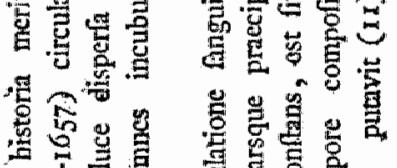

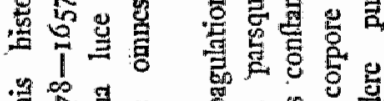

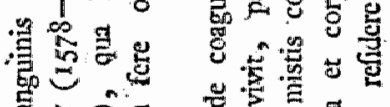

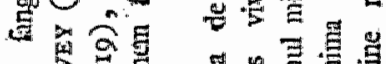

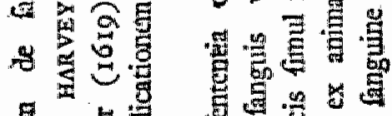

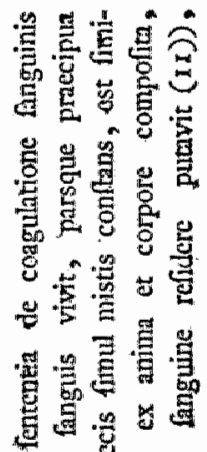

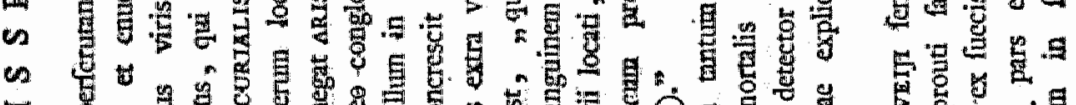

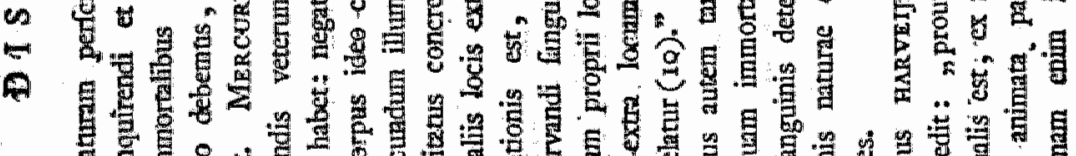

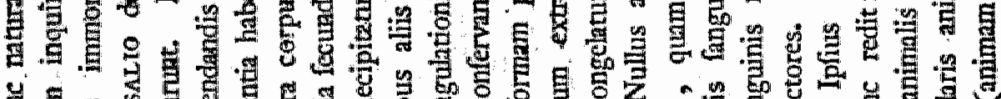

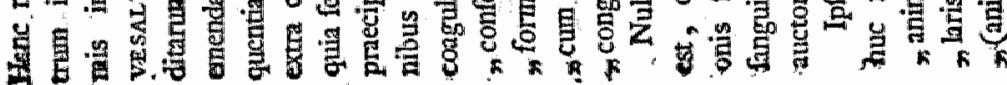




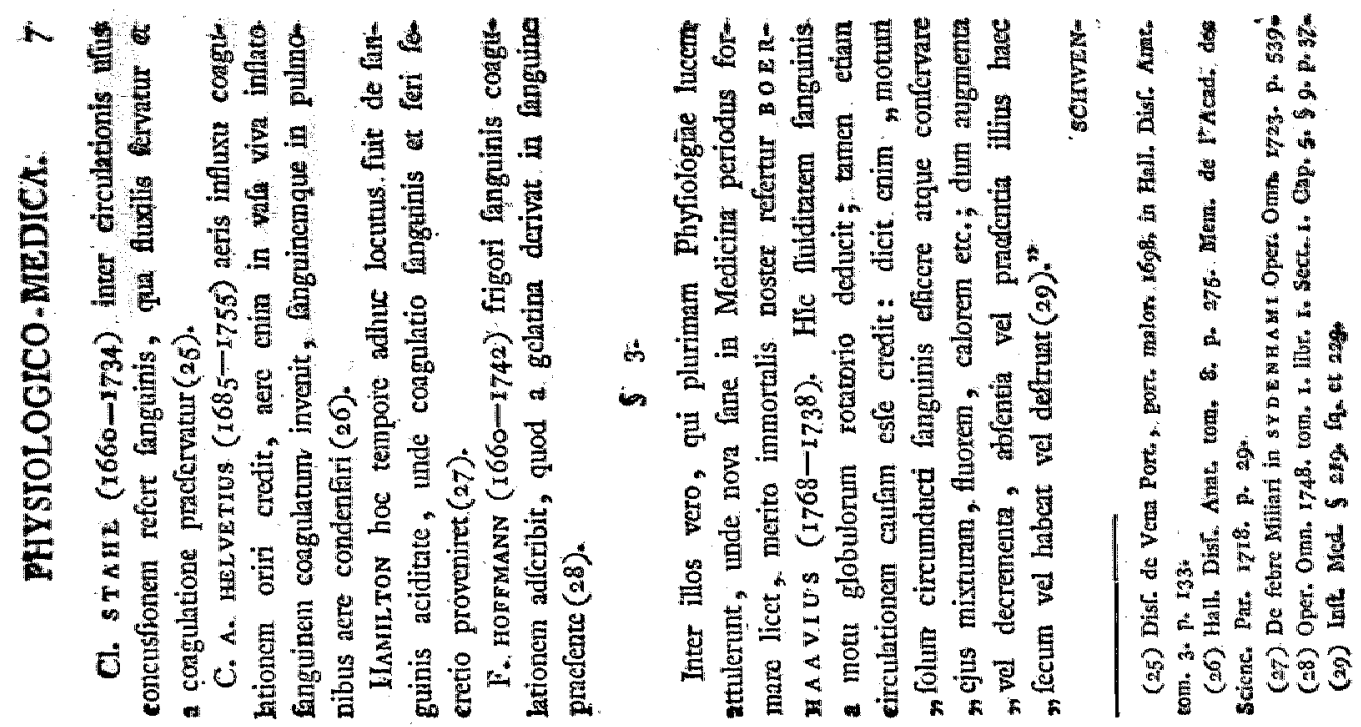

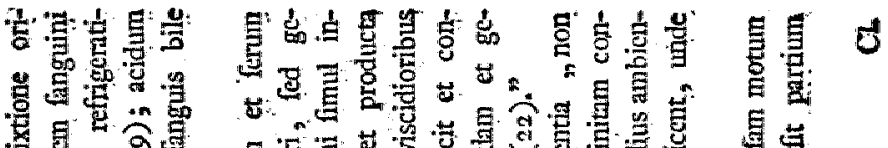

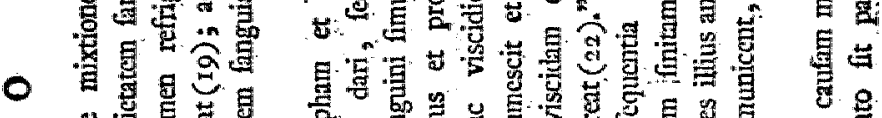

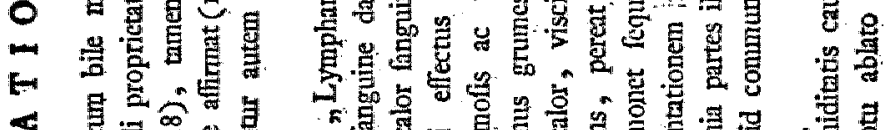

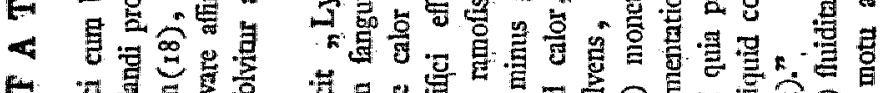

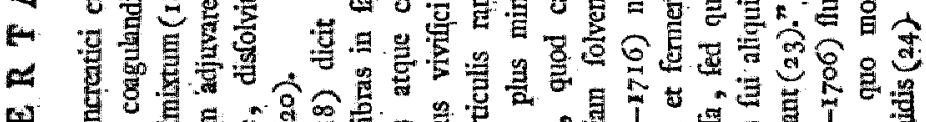

w

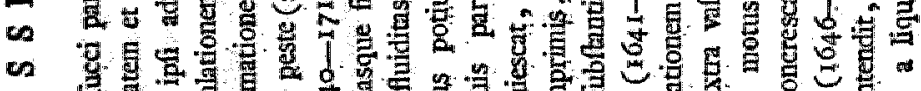

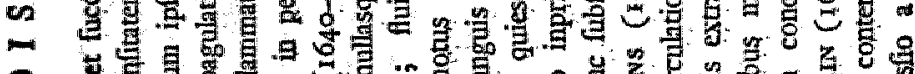

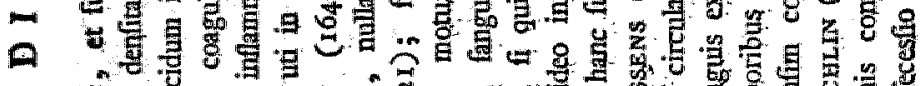

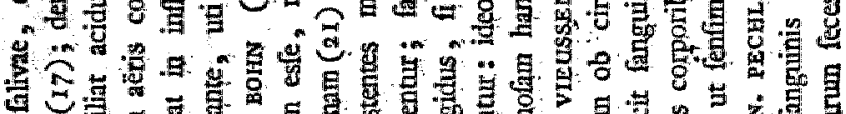

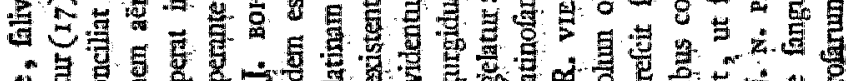

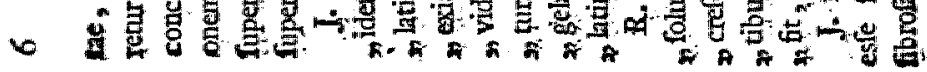

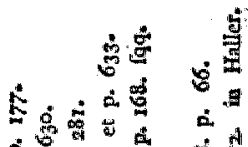

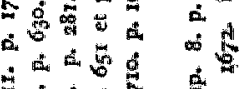

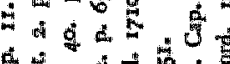

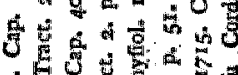

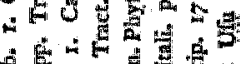

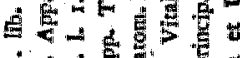
월

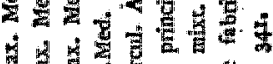
슬

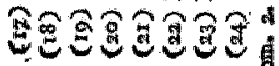




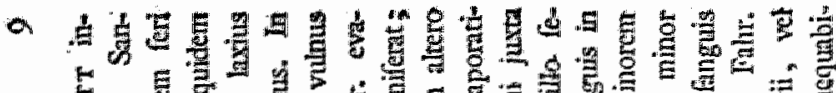

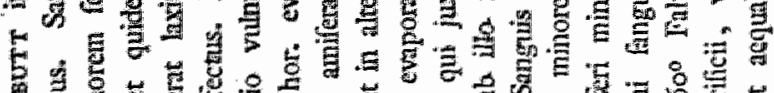

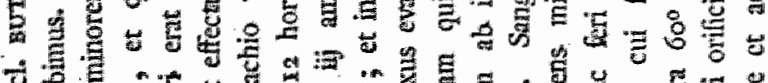

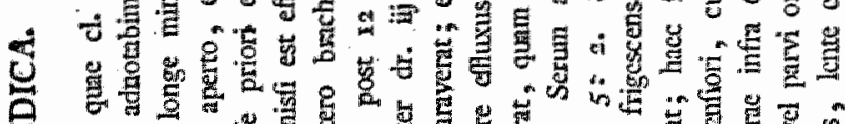

空

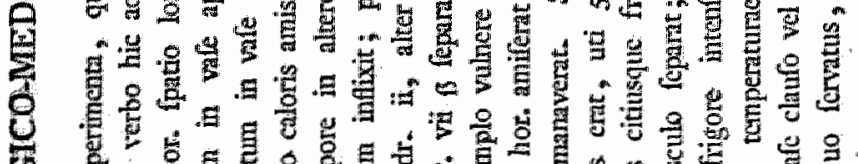

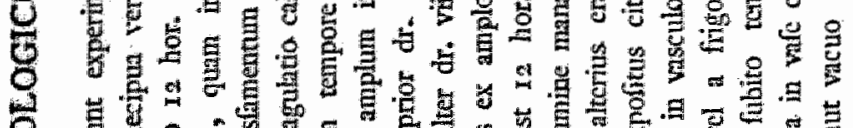

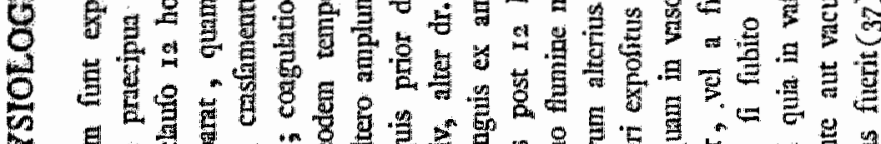

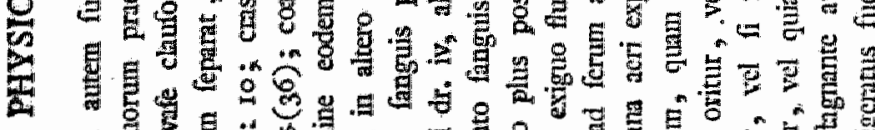

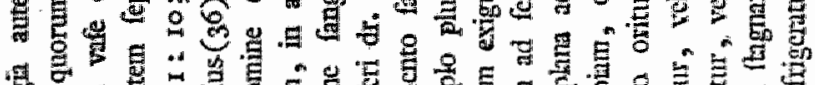

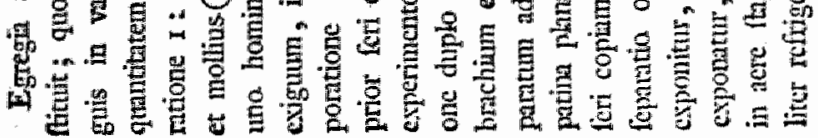

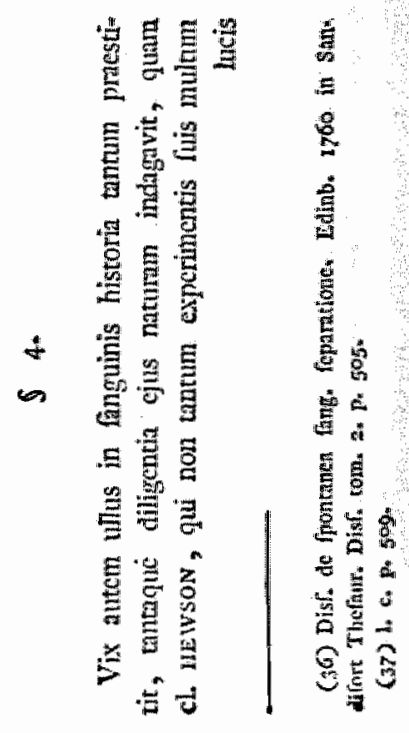

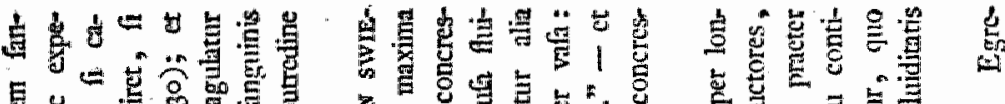

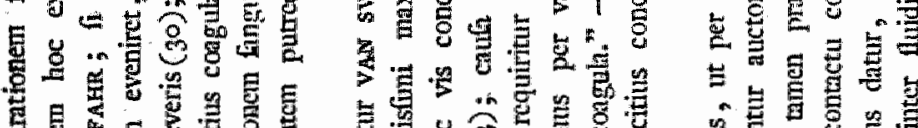

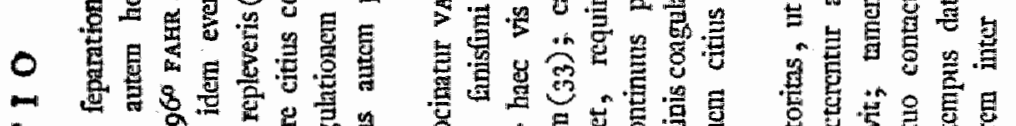

$\rightarrow$ o

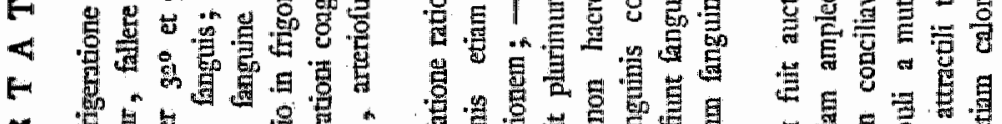

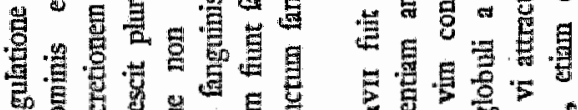

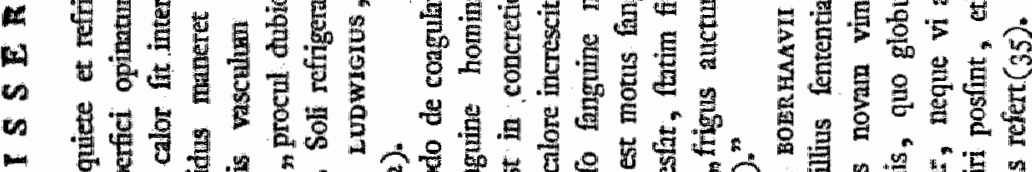

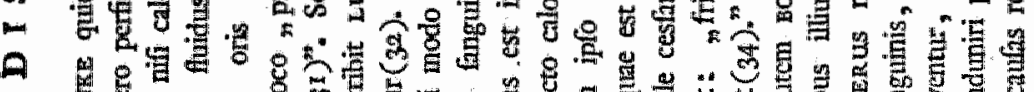

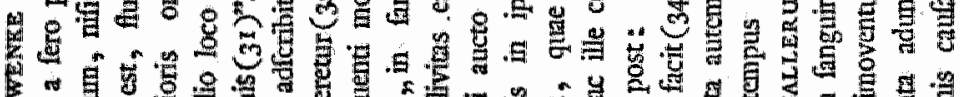

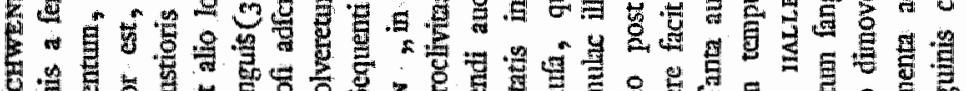

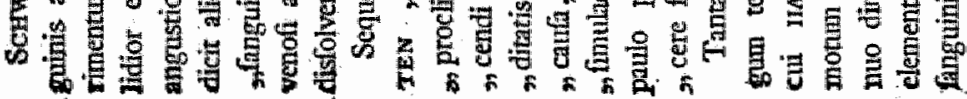




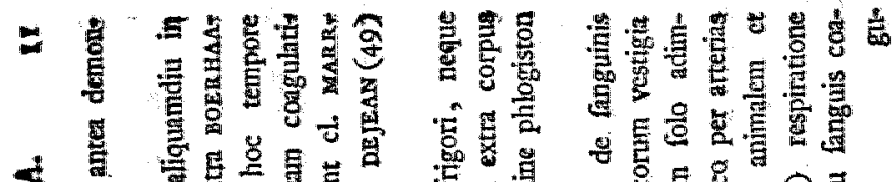

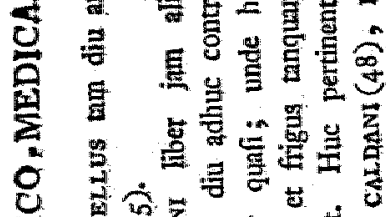

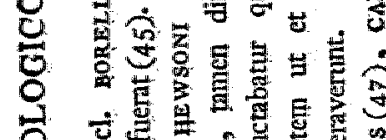

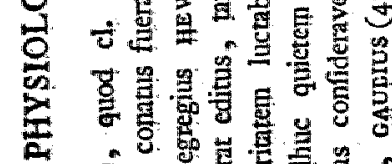

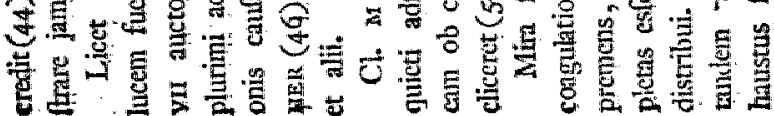

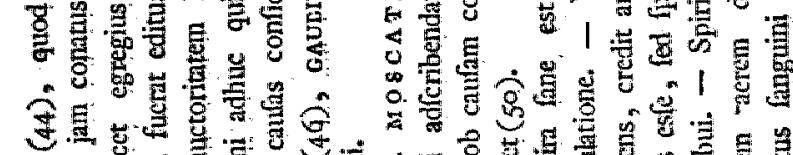

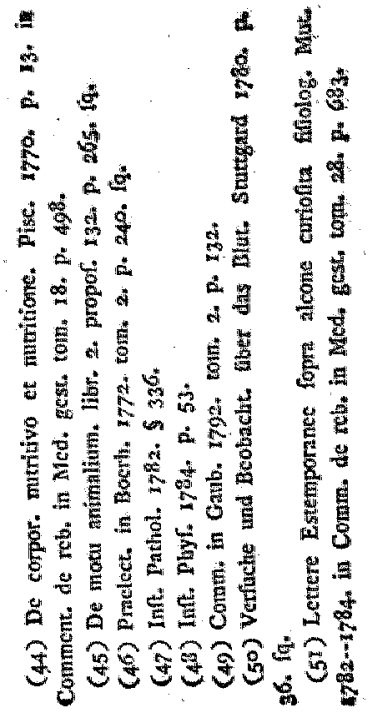

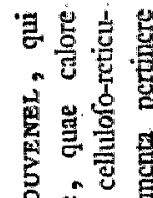

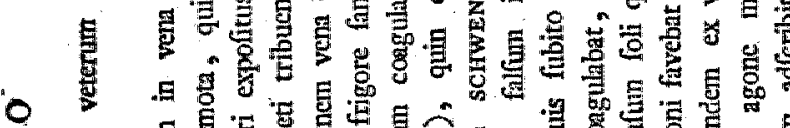

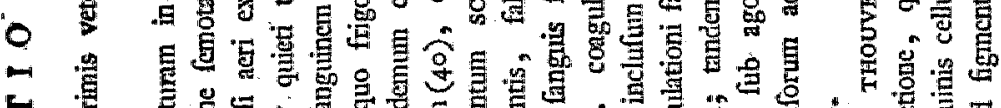

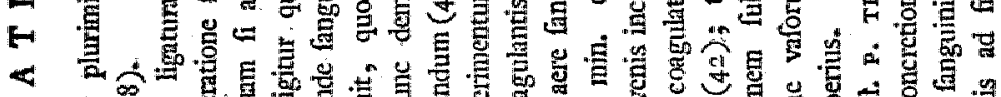

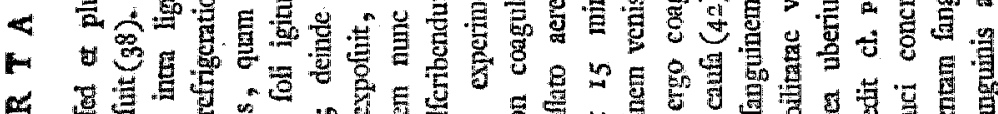

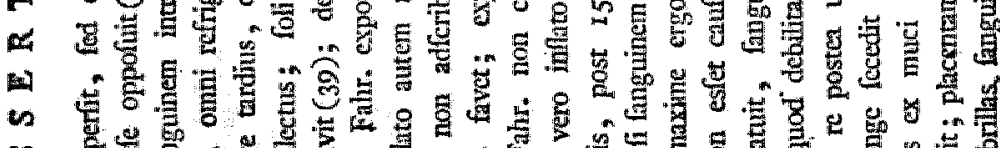

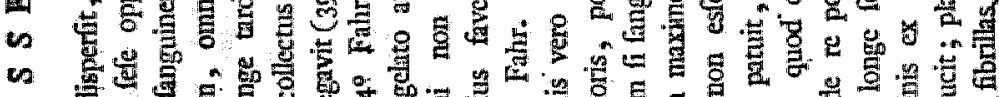

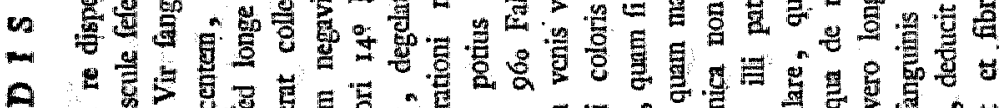

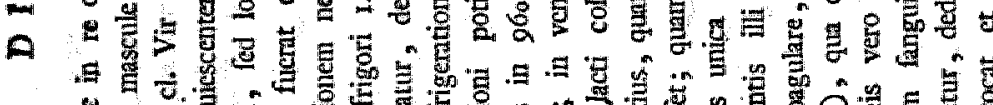

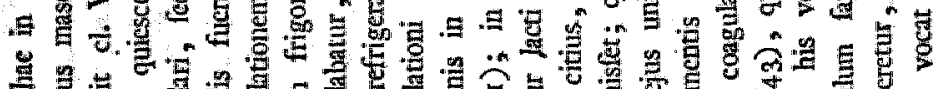

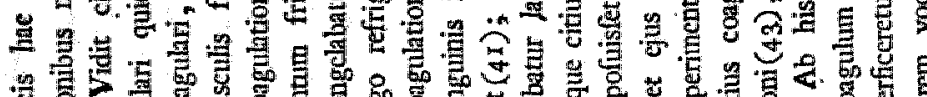

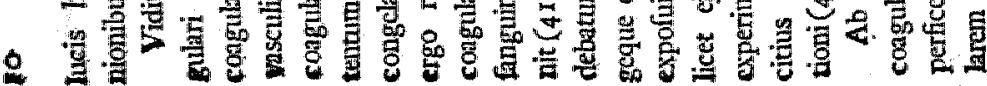

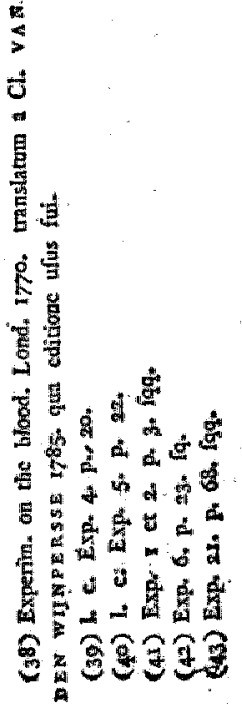




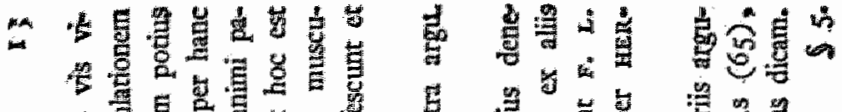

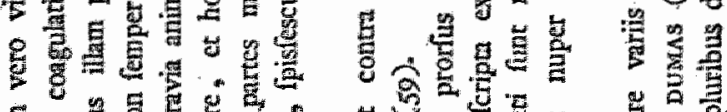

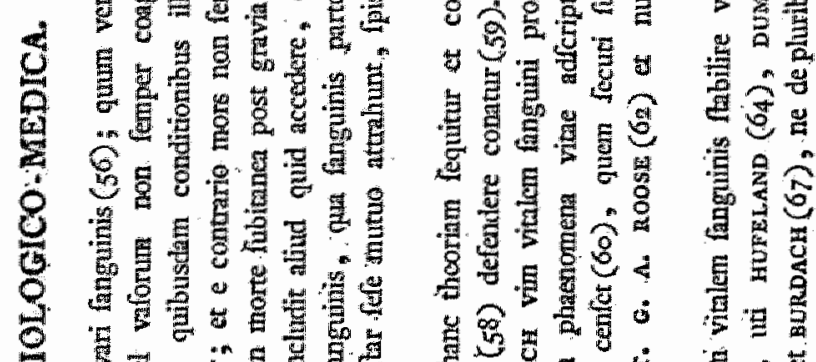

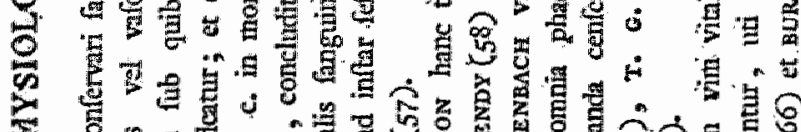

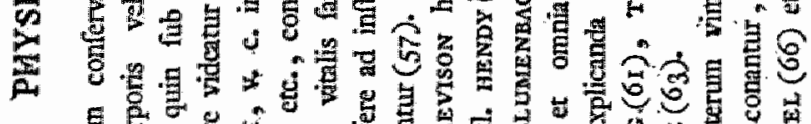

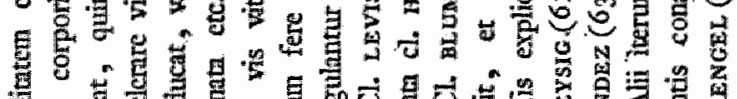

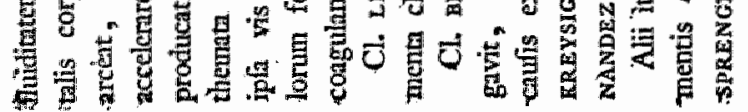

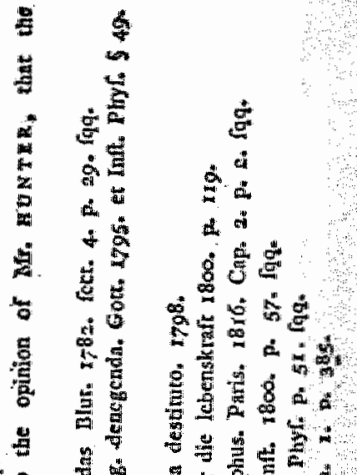

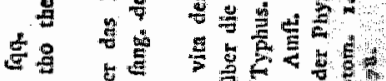

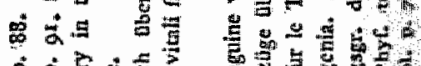

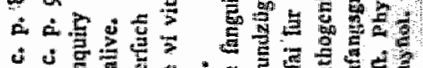

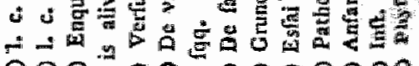

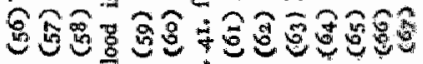

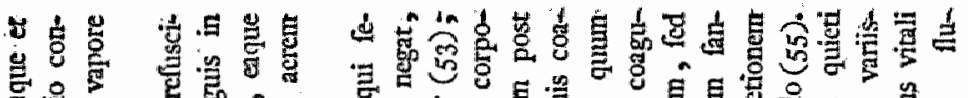

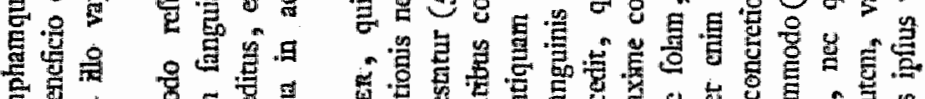

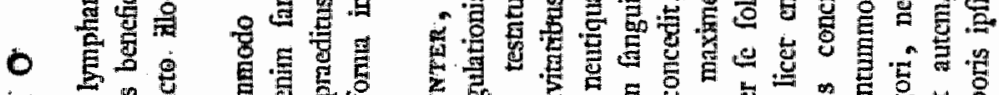
年 H E

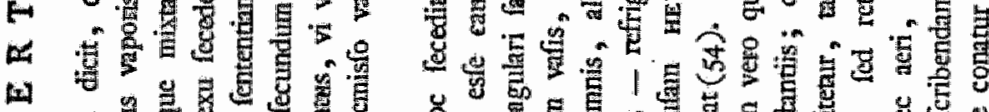

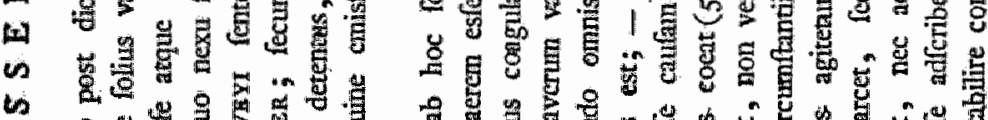

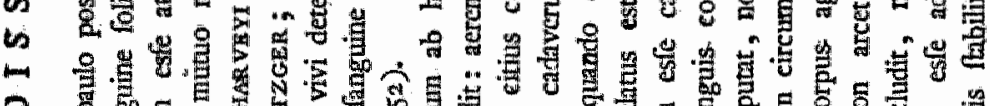

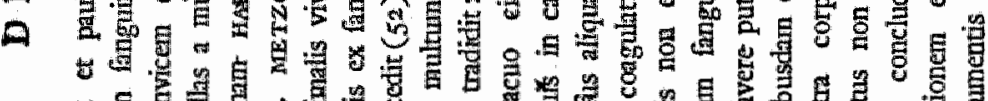

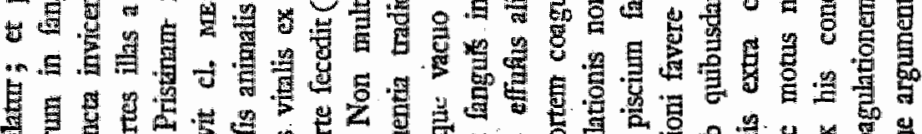

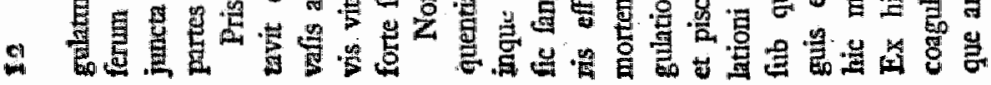

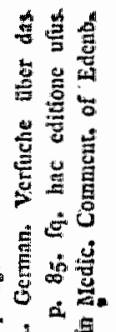

से

尌部

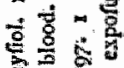
迸焉 筞

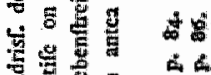
焉焉量

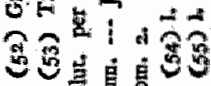




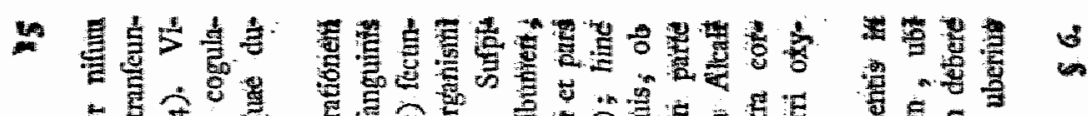

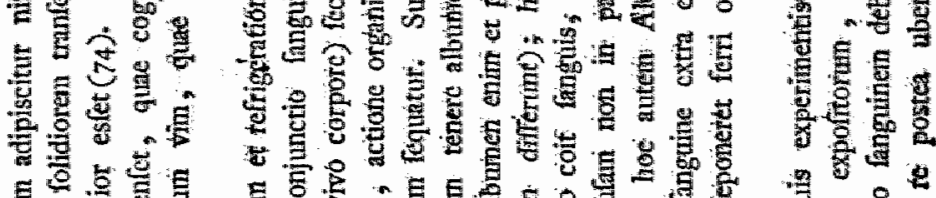

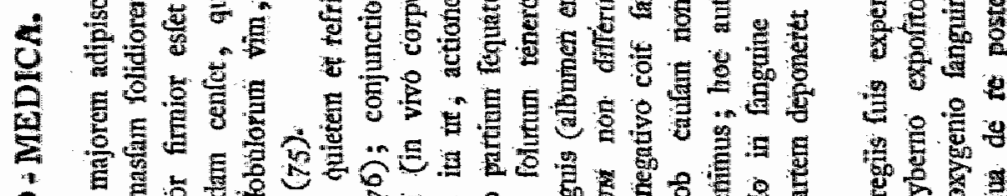 ó

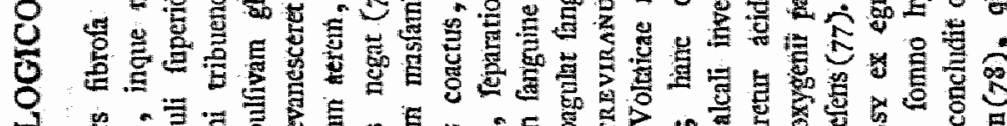

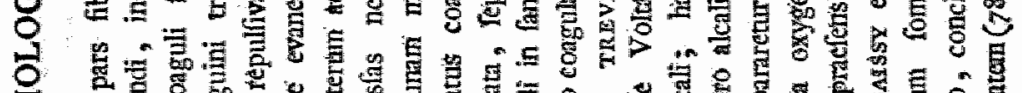

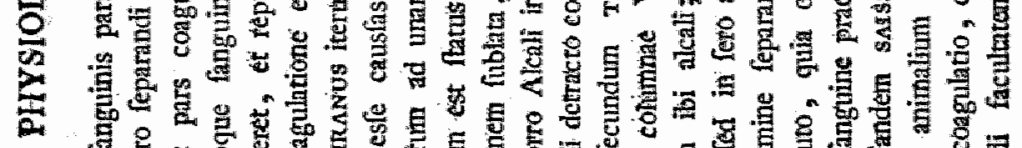

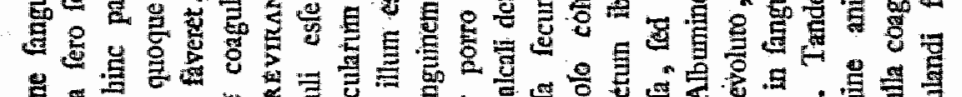

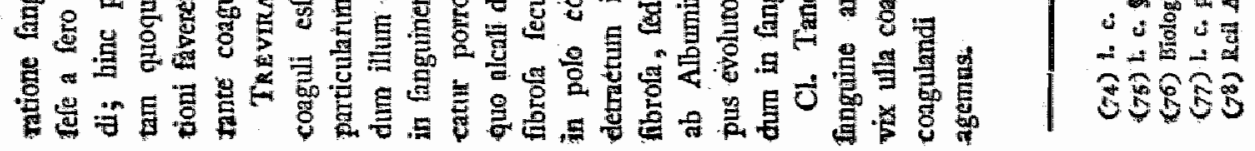

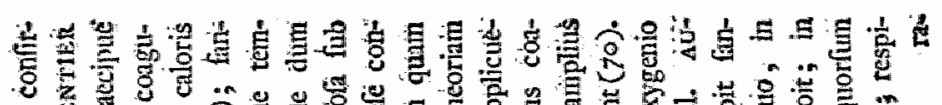

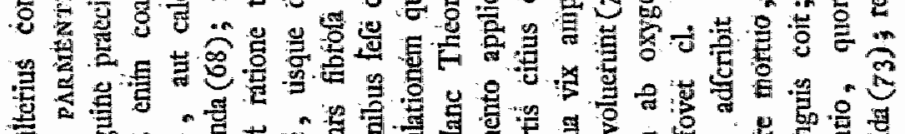

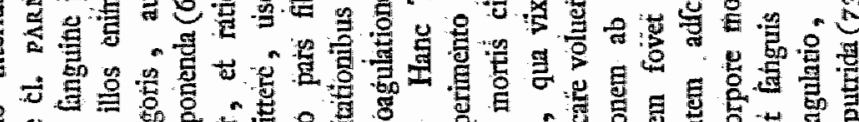

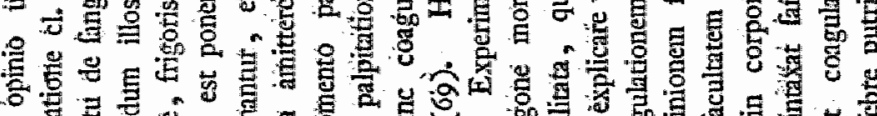

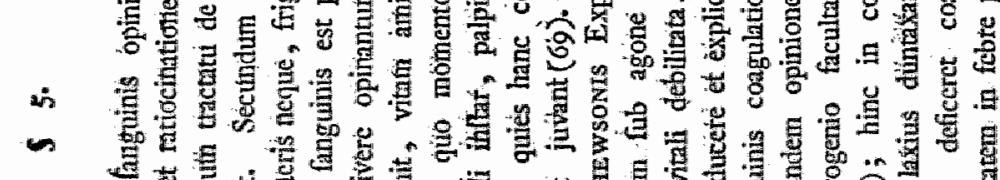

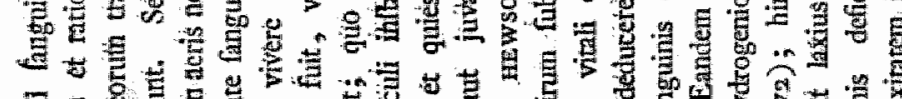

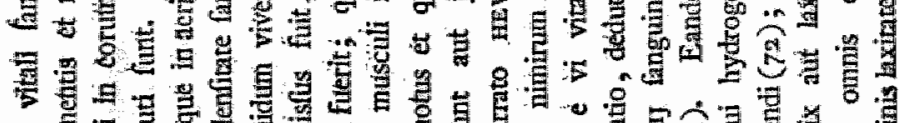

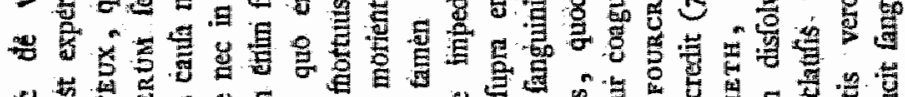

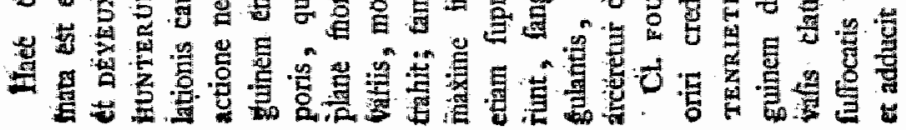




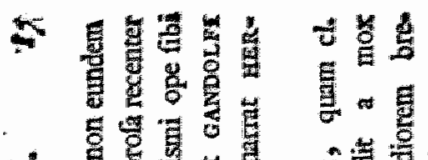

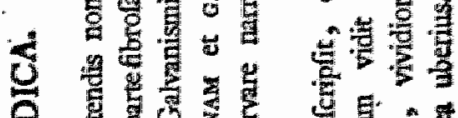

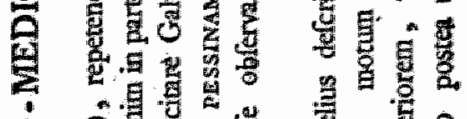

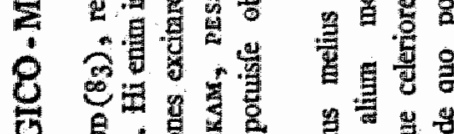

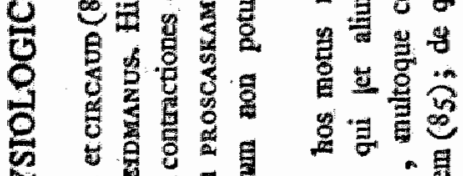

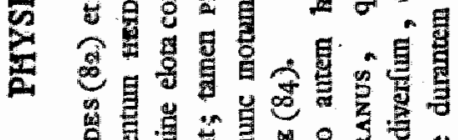

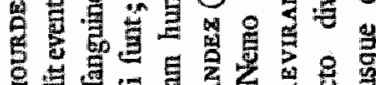

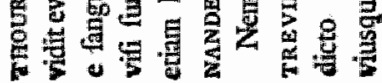

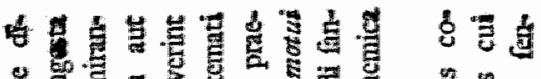

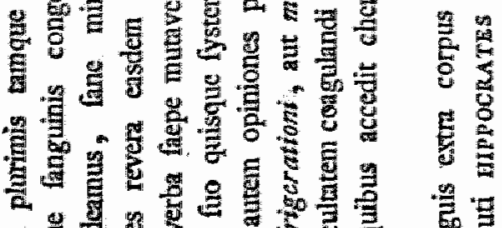

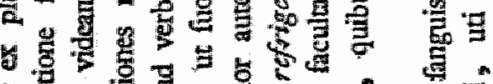
-

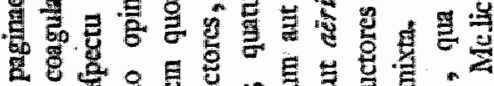

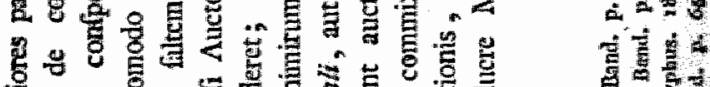

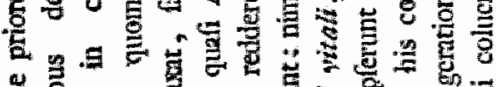

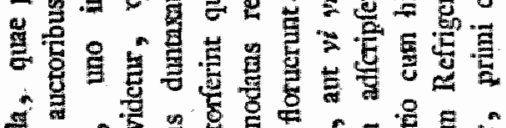

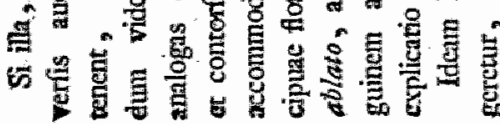

$\therefore \div$ 20
$\therefore=8$ a 5 ह 荧些。

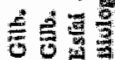

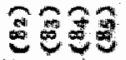

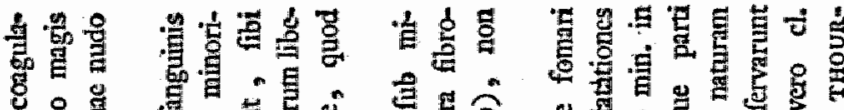

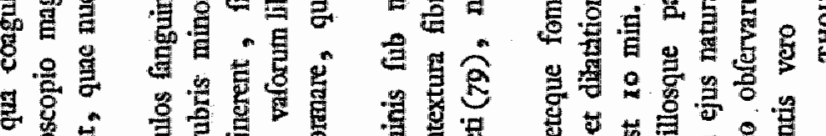

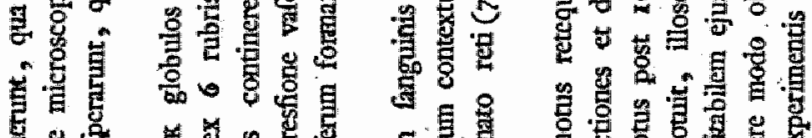

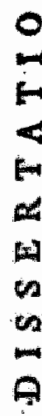

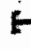

9
落 息.

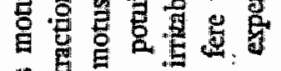
弹寒

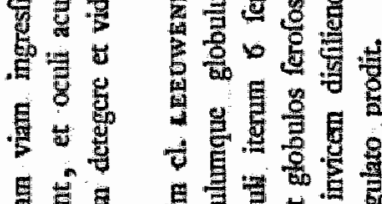

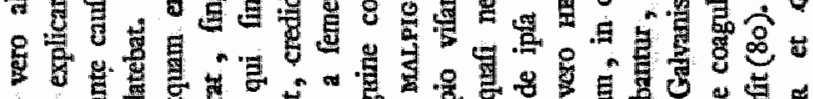

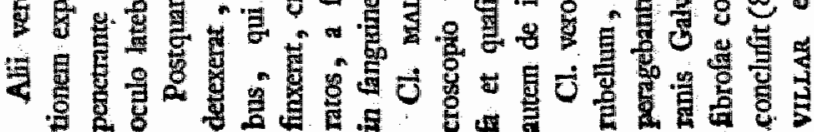

2

量

葛

蒀

总 总

है 5

है

\&

क 10

단

莒

온 


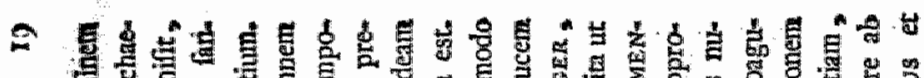

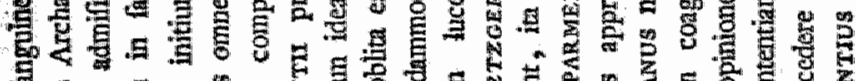

ชิ

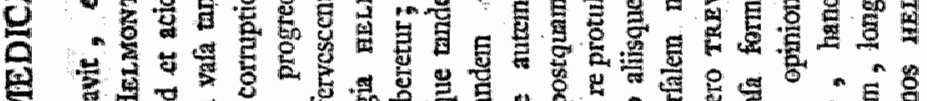

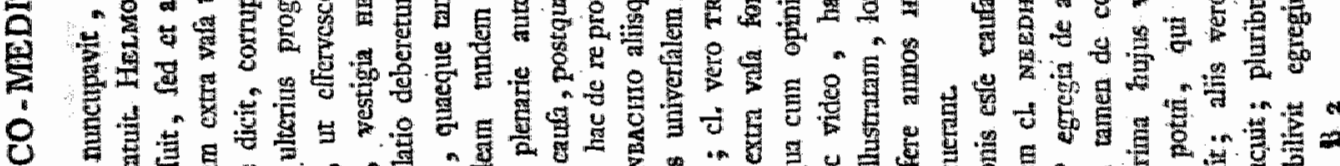
을 空

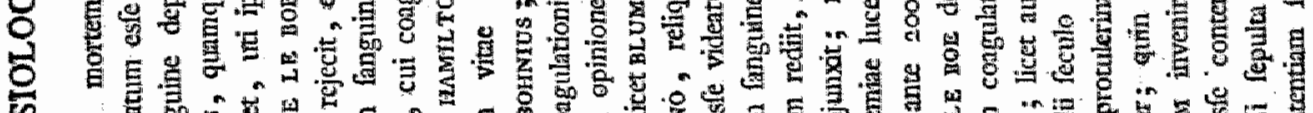

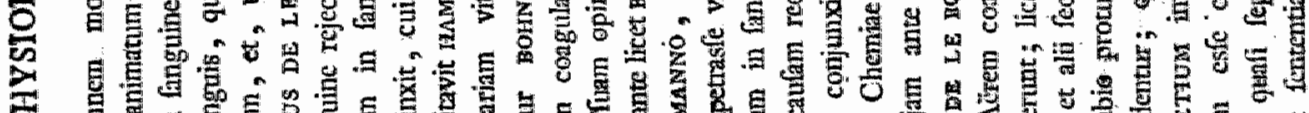

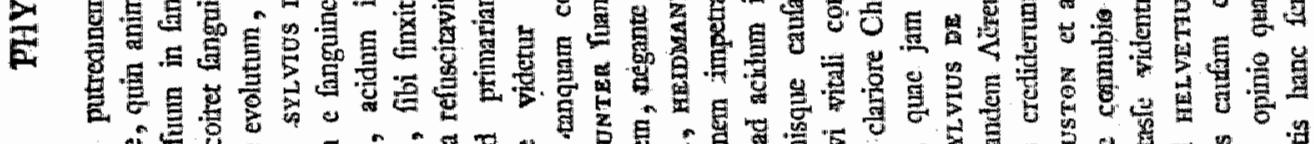

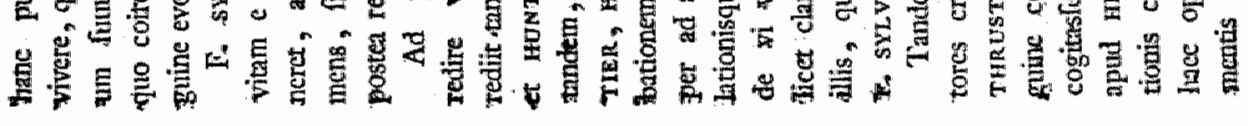

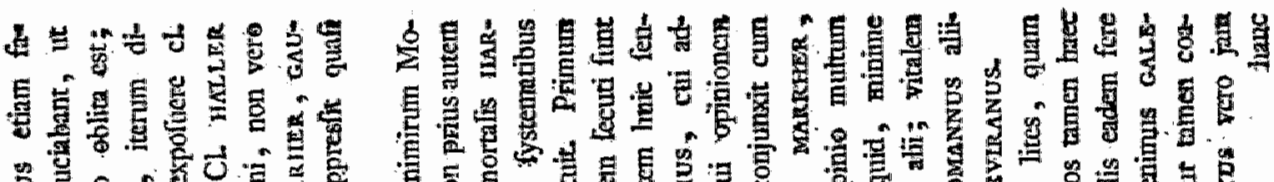

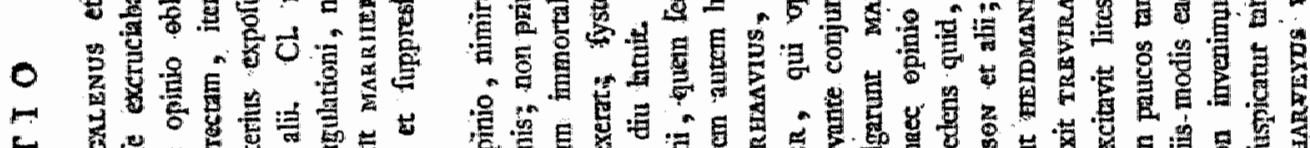
F F

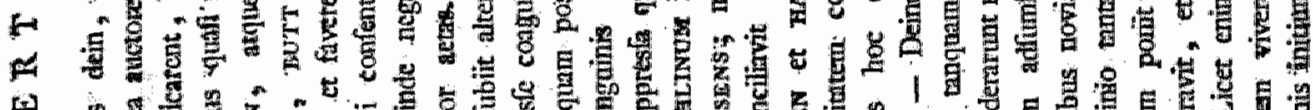

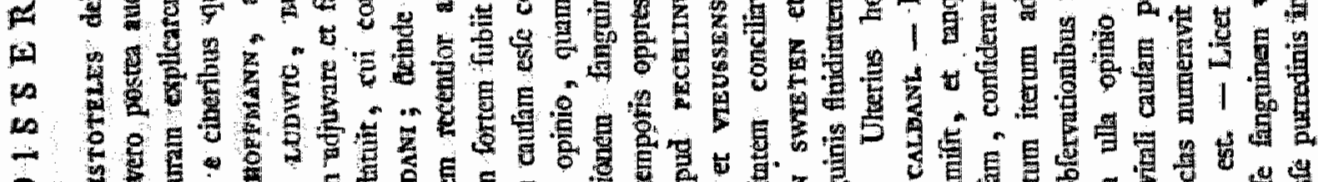
A

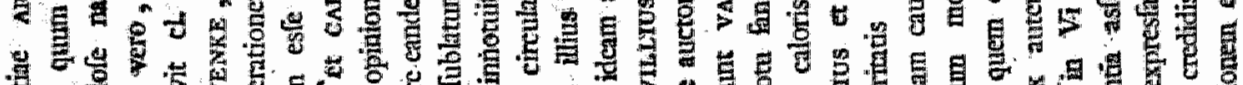
-

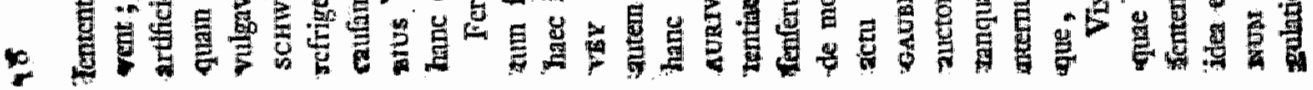




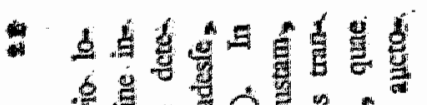

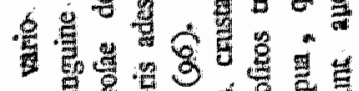

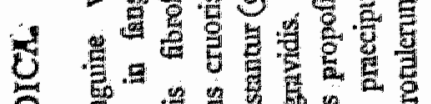

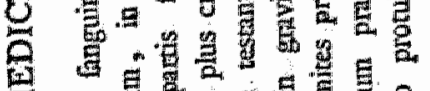

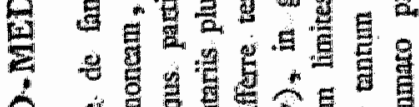

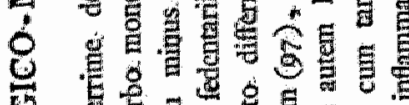

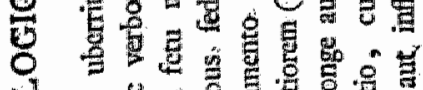

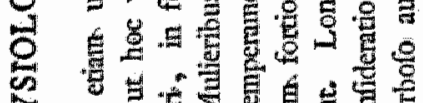

帘

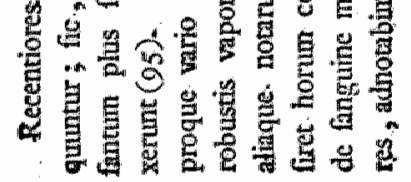

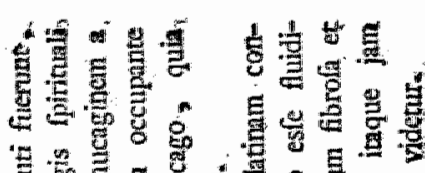

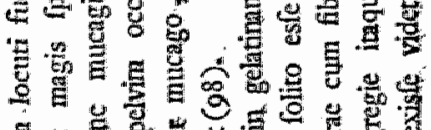

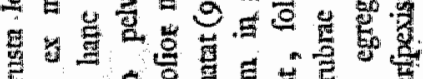

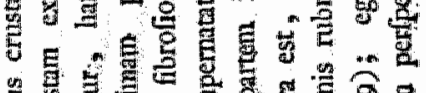

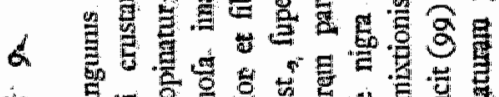

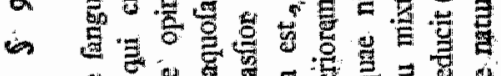
을

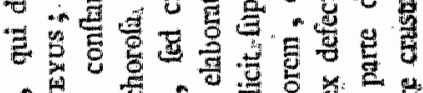

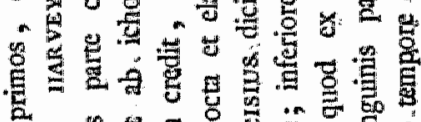

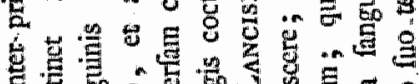

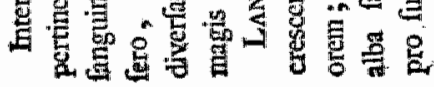

总

-

部

ค.

เू

ง. क ह है:

迹

$\div$ के

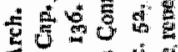

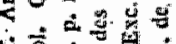

둥

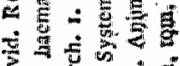

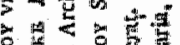

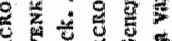

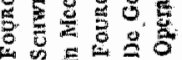

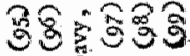

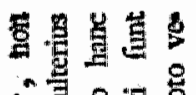

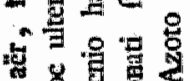

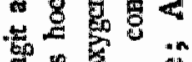

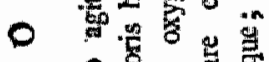

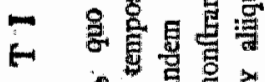

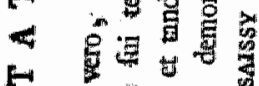

4 最

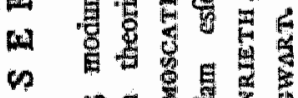

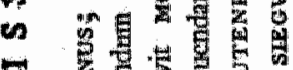

两

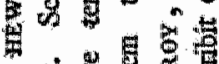

䔽基

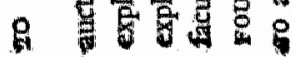

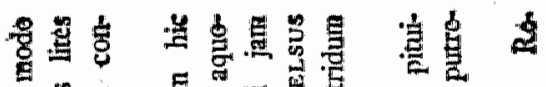

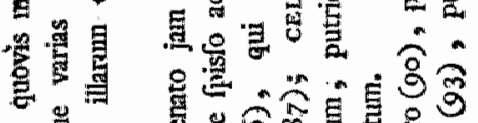

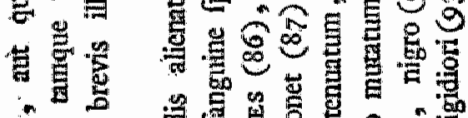

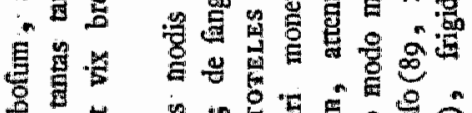

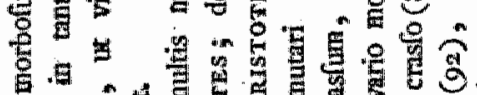

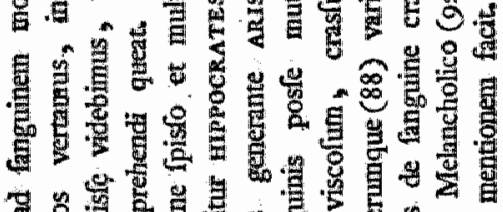

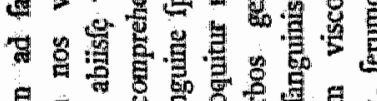

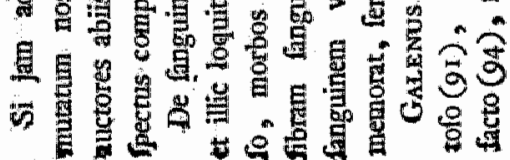

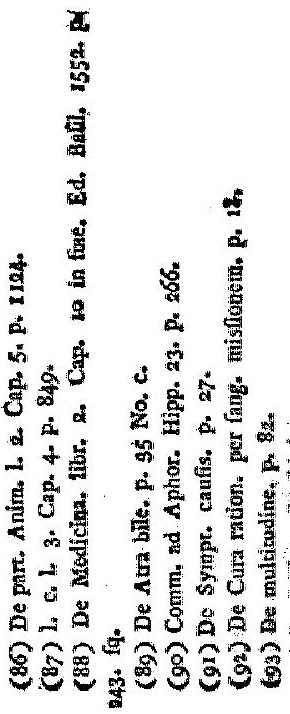




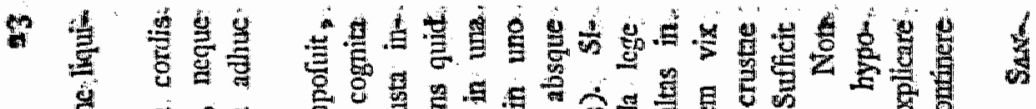

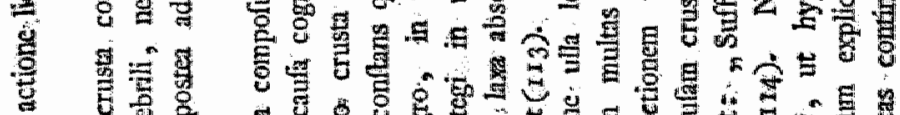

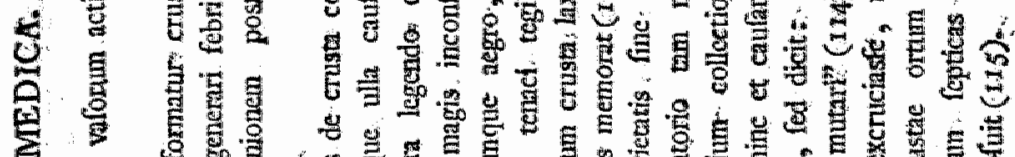

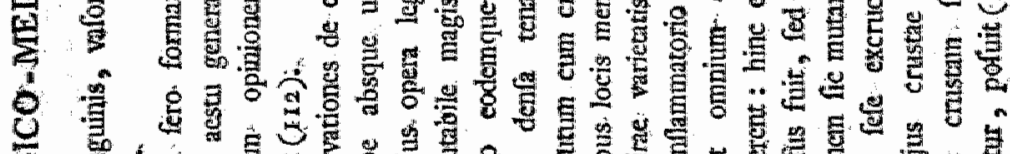

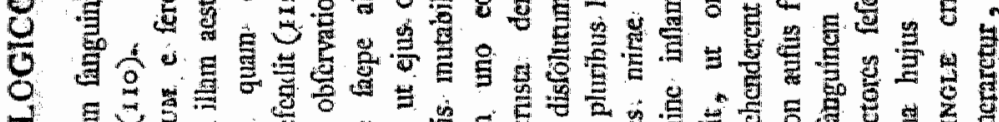

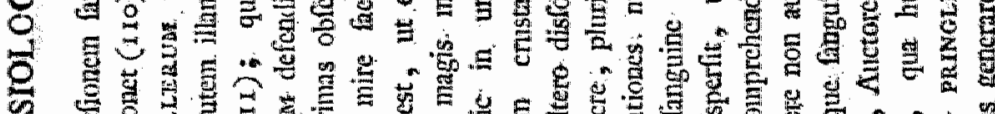

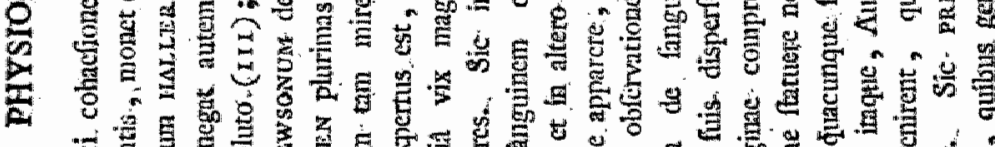

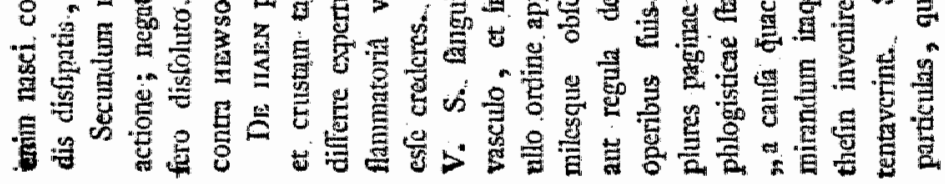

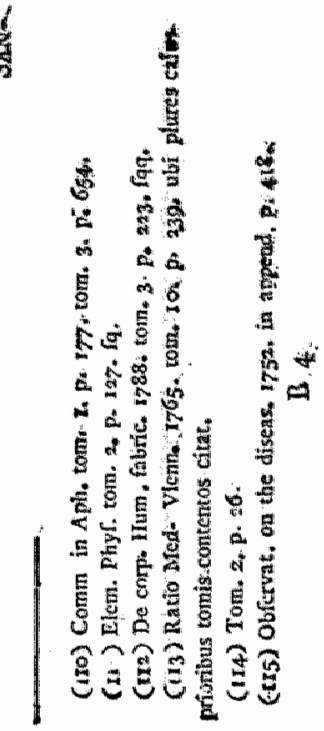

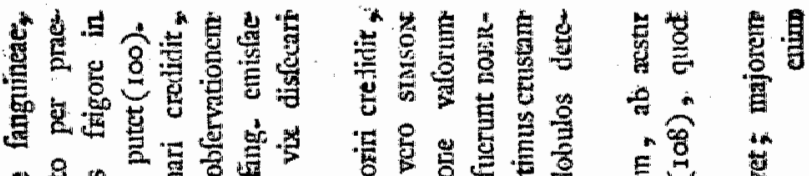

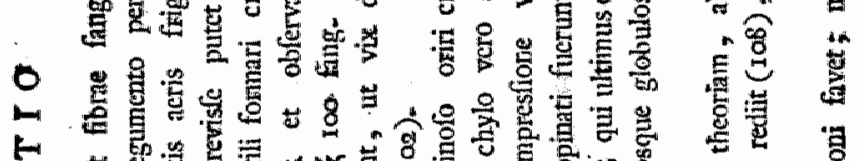

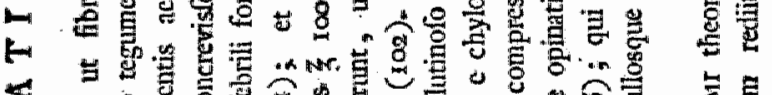

5 证

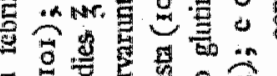

竞

曼

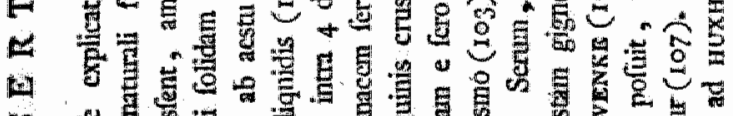

萡

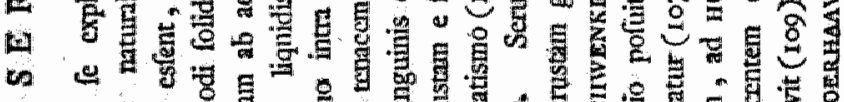

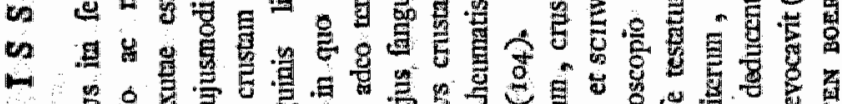

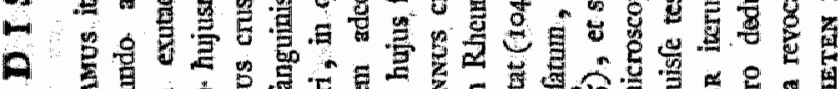

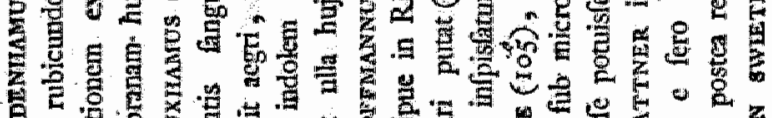

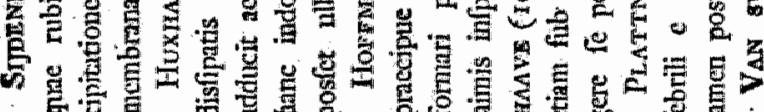

:

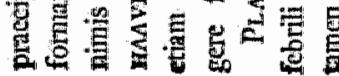

s

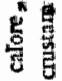

हE.

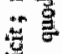

के

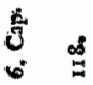

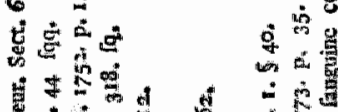

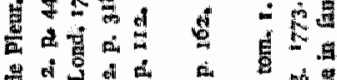

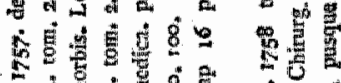

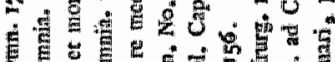

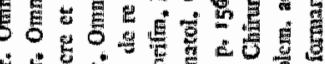

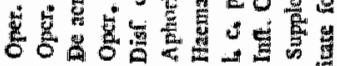

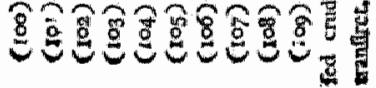




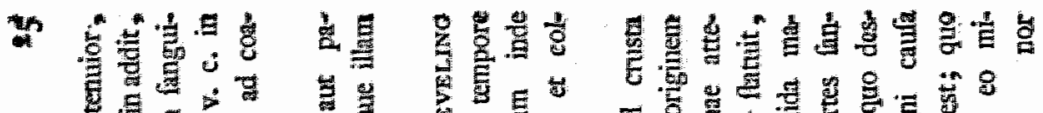

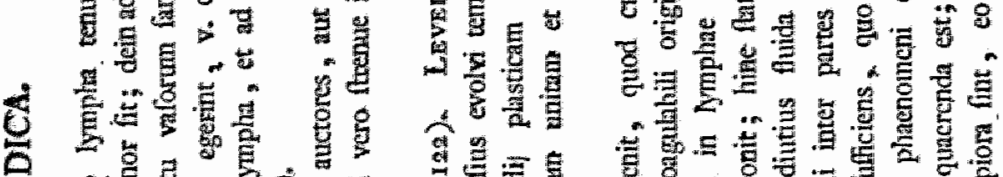

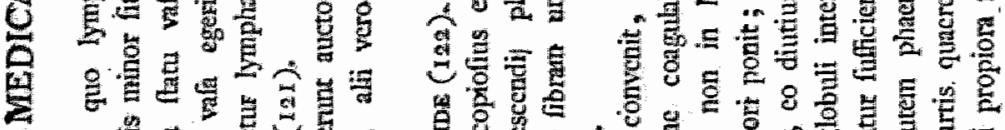

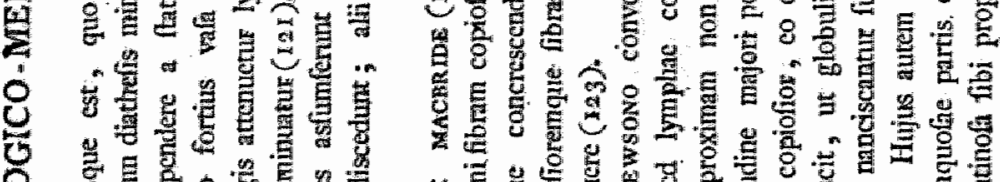

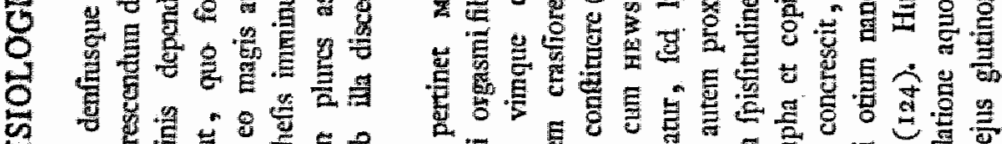

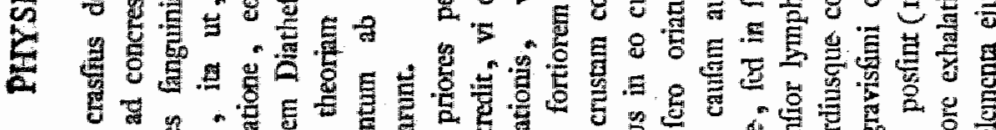

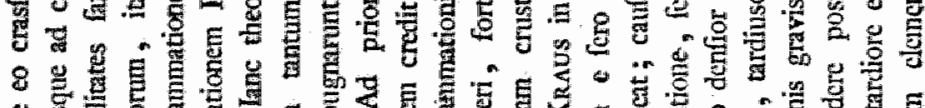

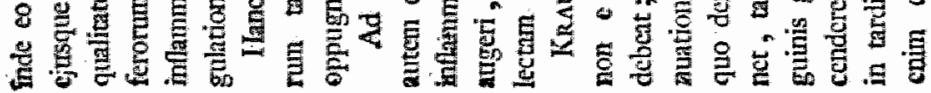

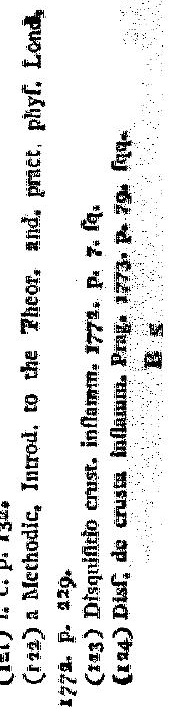

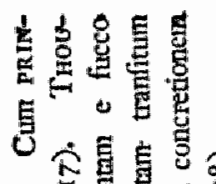

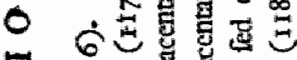

F

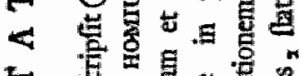

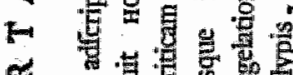

a

s

-

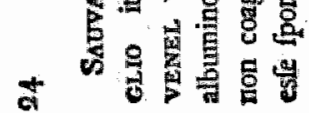

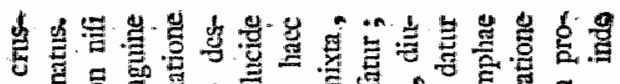

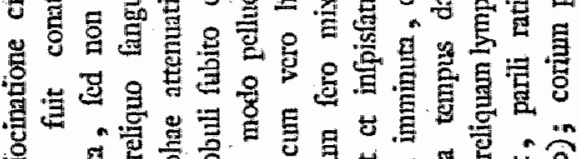

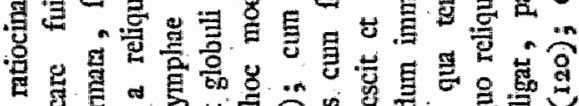

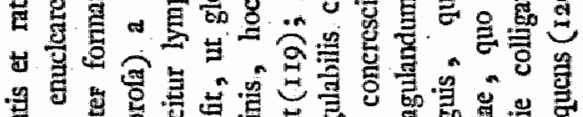

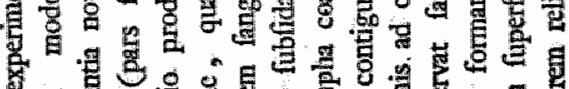
4 .

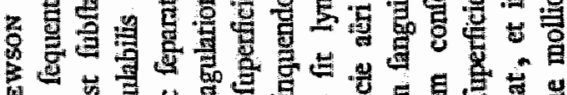

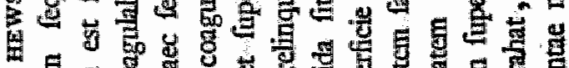
竞

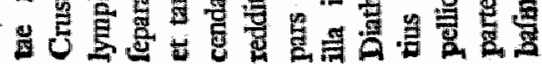

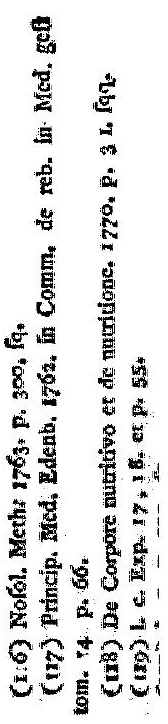




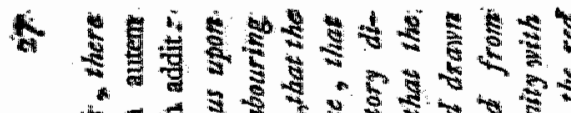

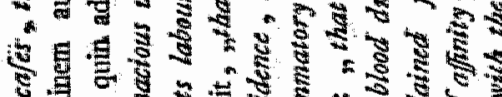
S
昰
0 है

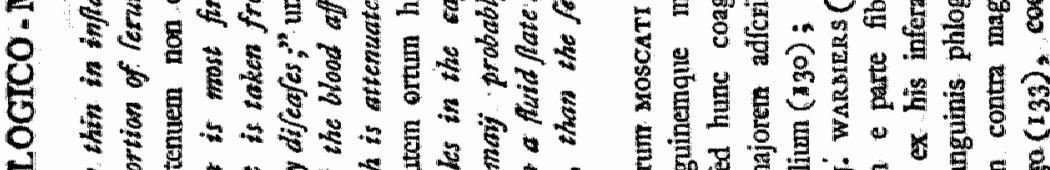
要

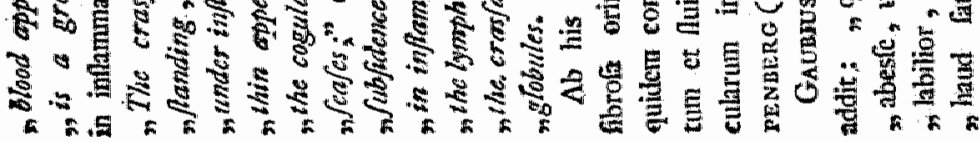

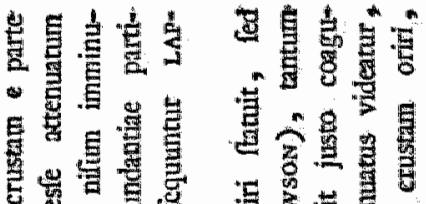

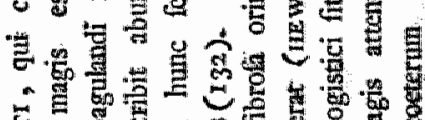

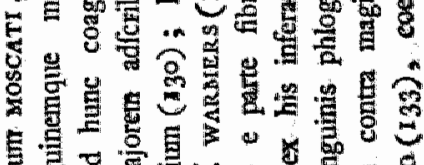 要

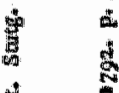
要

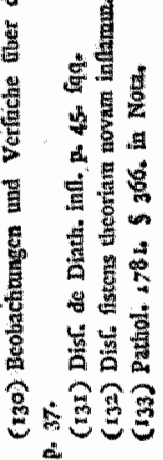

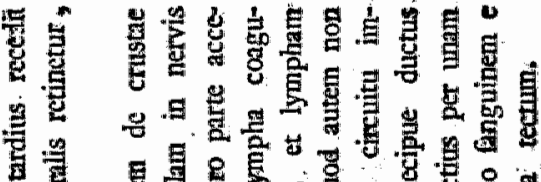

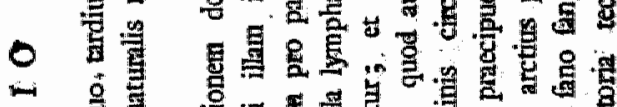

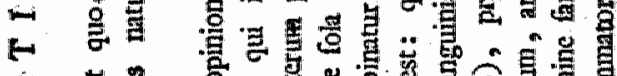

45 年

净

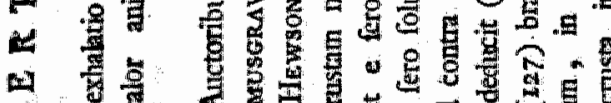

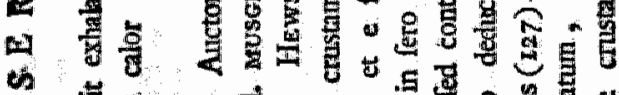

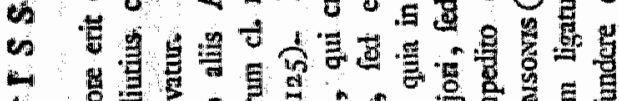

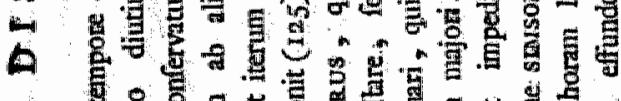
15 5 .

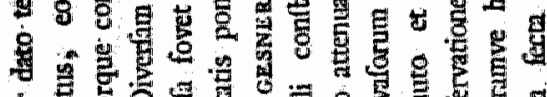
은

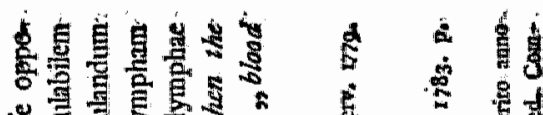

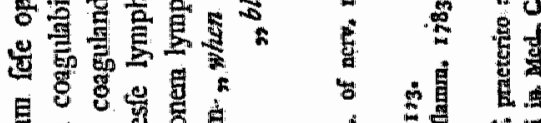

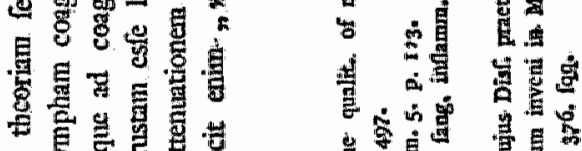

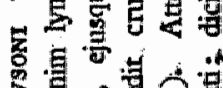

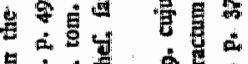

的竞

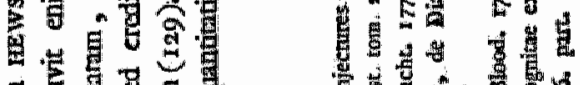

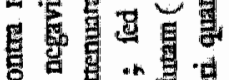

용 恶

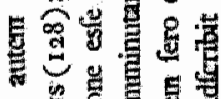

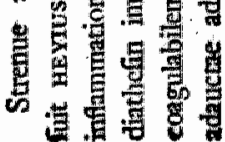

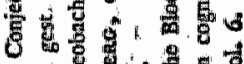

पे है

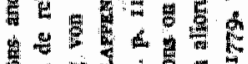

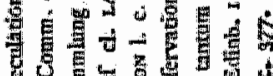

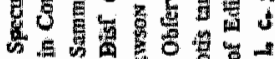

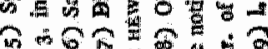

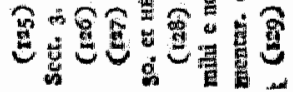




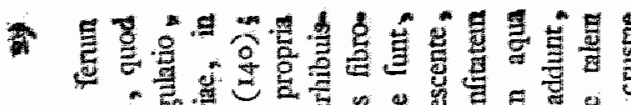

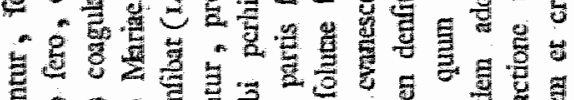

过 s

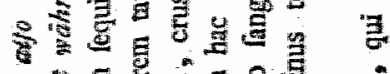

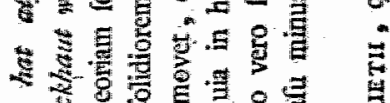

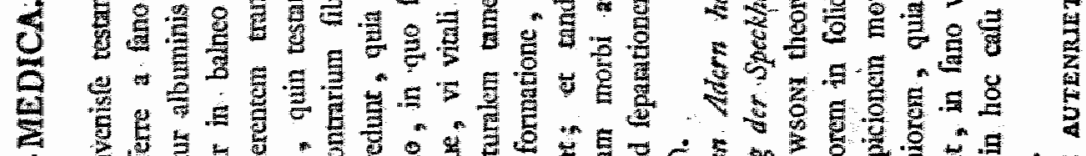

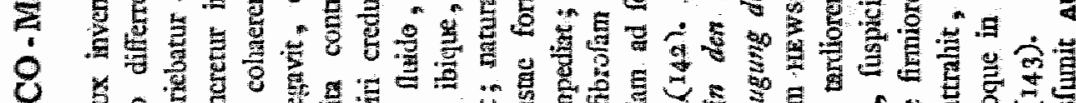
8 俤等

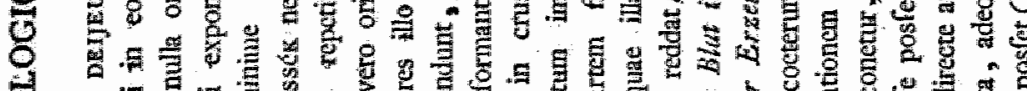

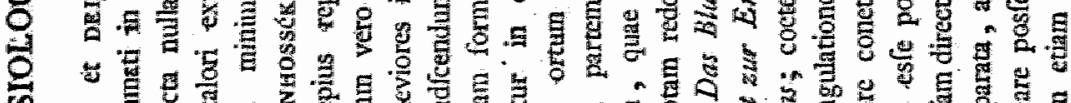

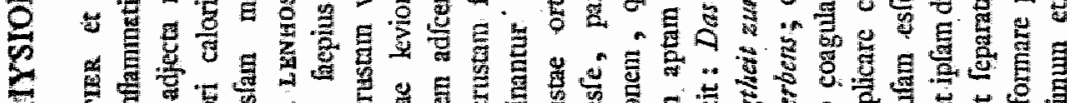

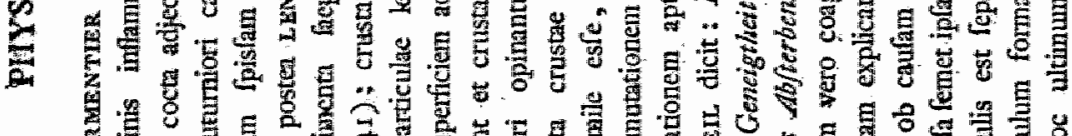

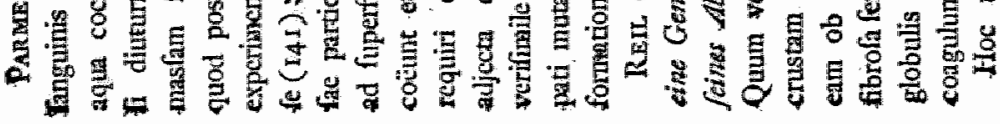




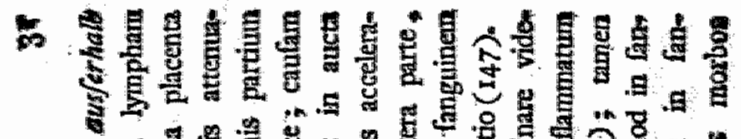

ช

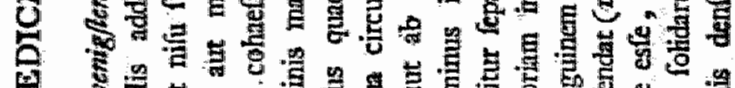

舟

它

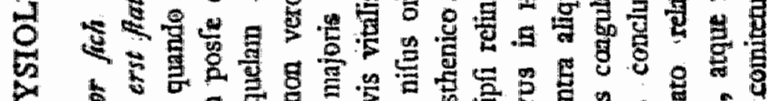

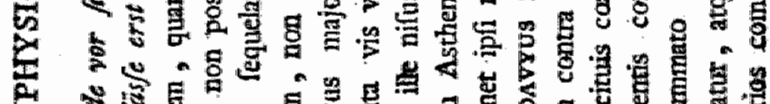

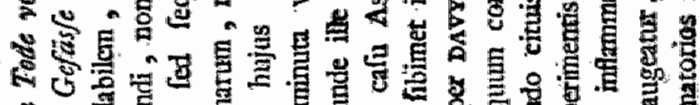

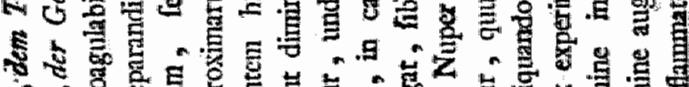

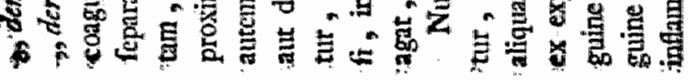

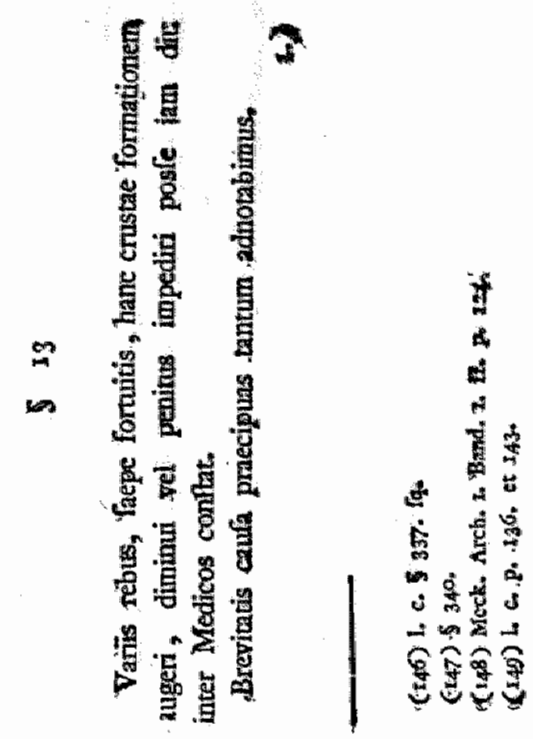

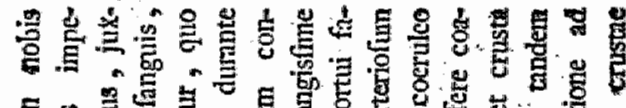

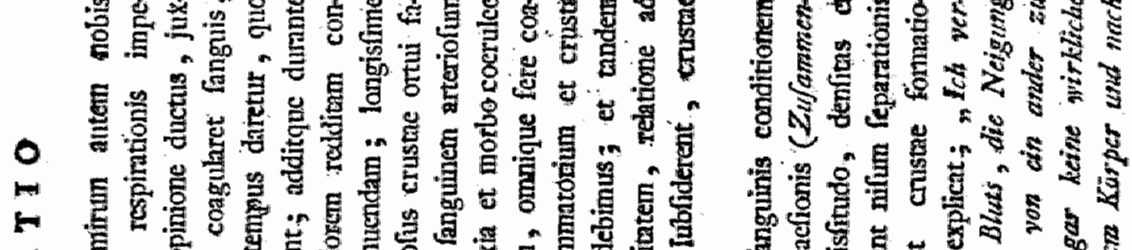

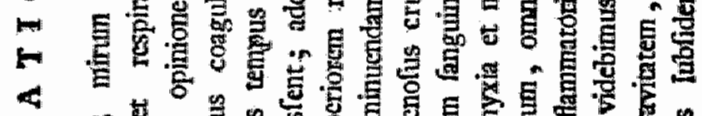

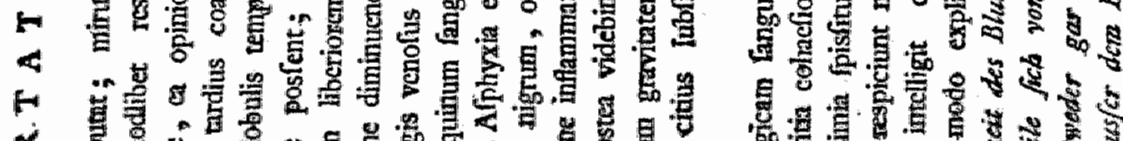

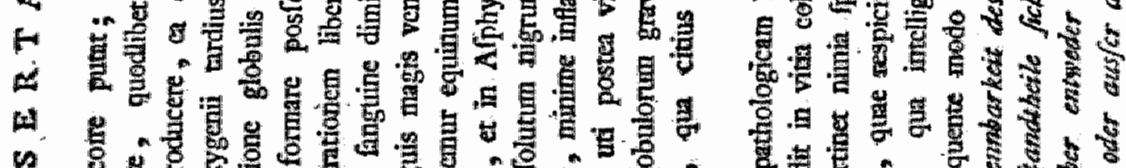

出

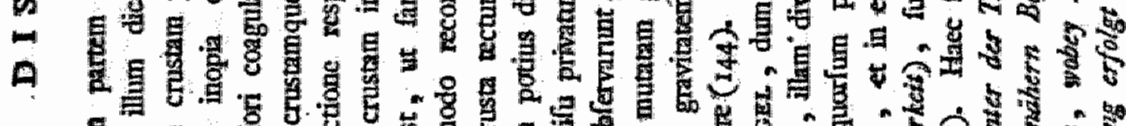

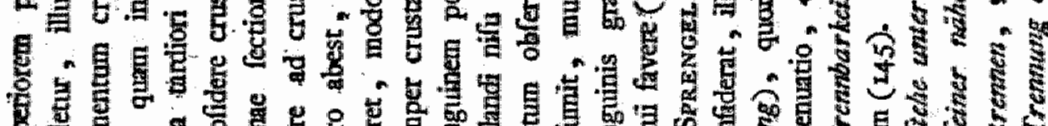

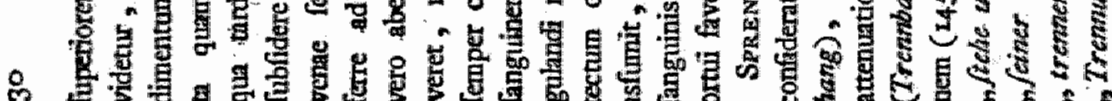

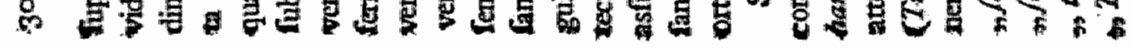

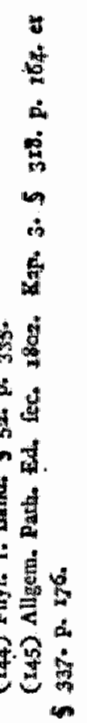




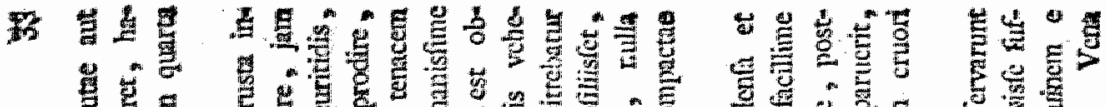

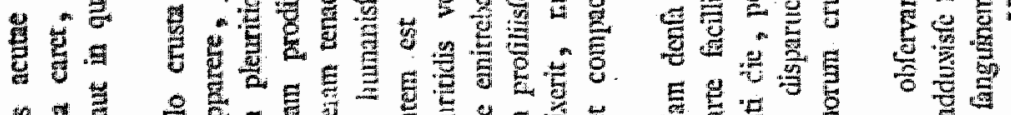

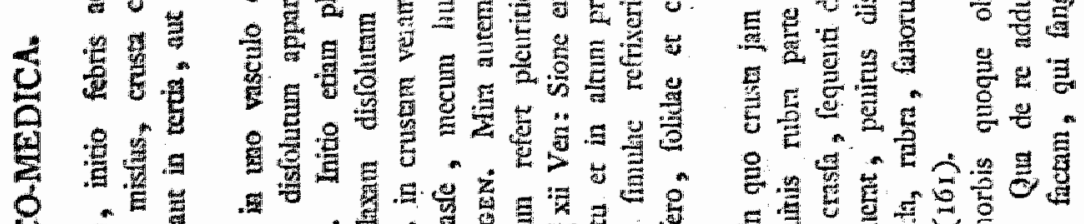

8 .

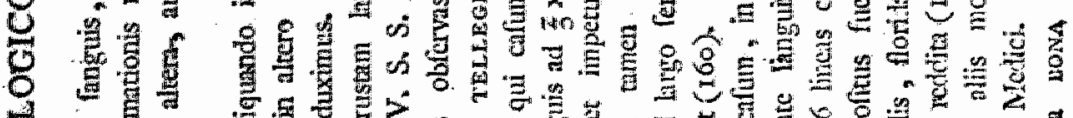

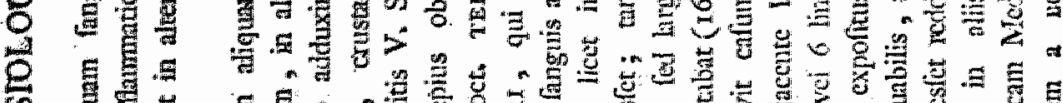

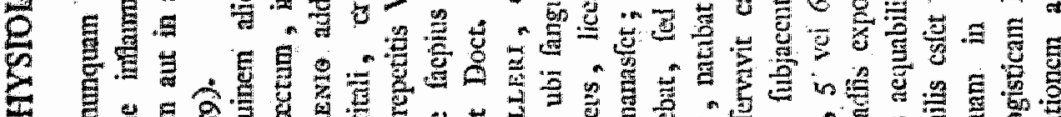

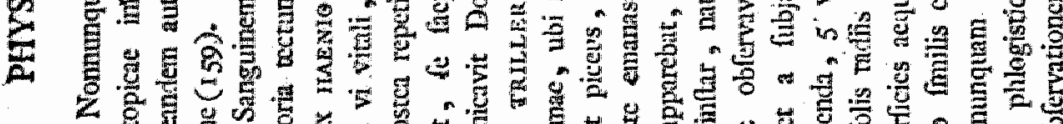

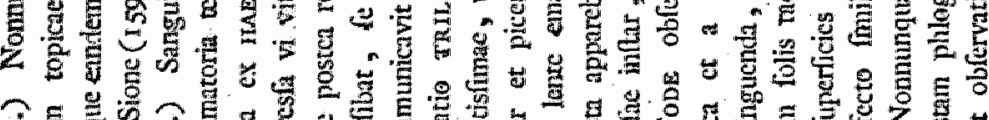

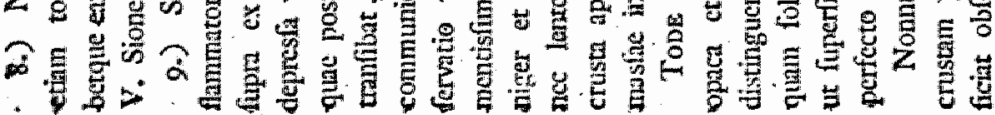

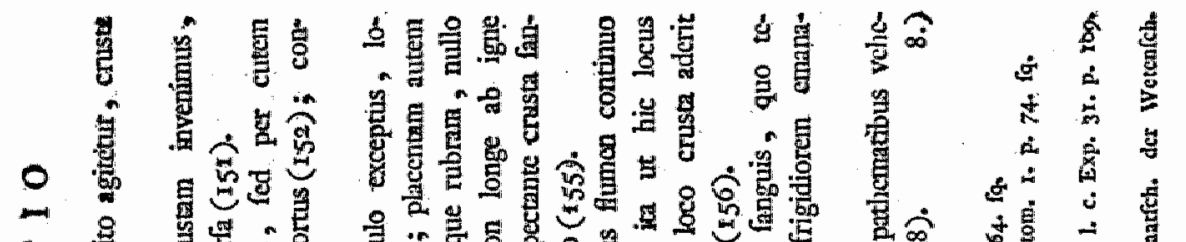

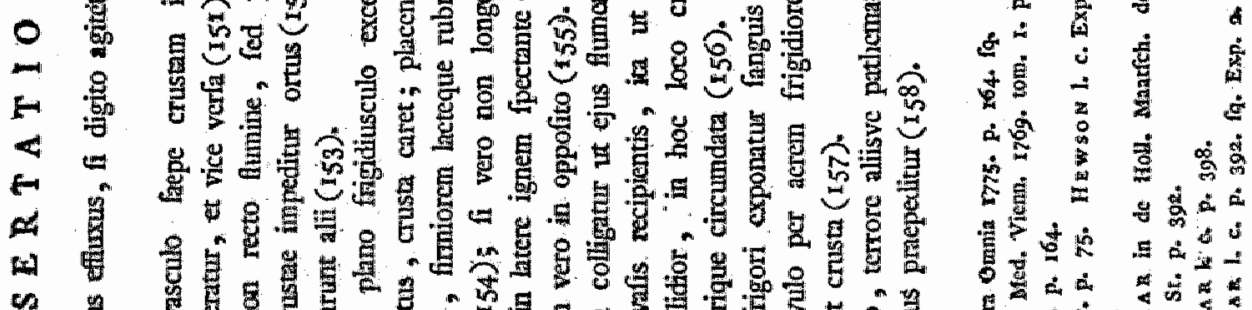

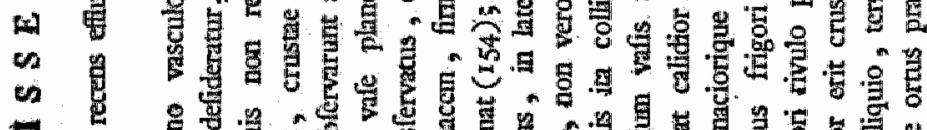

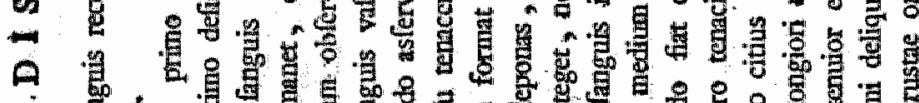

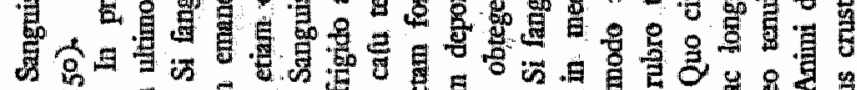

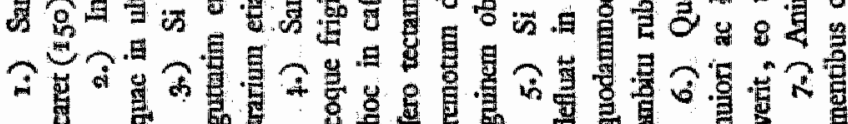

म

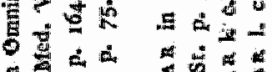

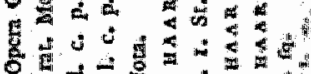
z 要等

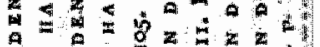

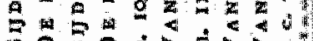

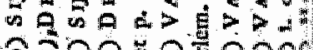

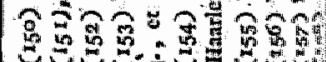
๓ 
$\check{\infty}$

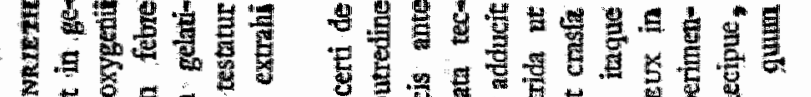

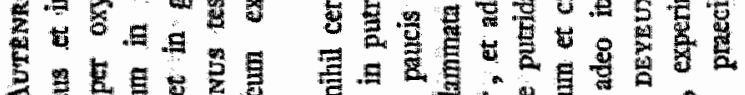

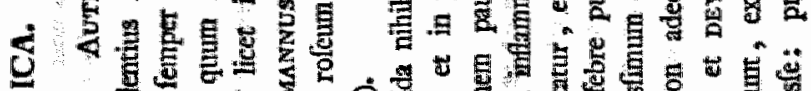
0 然

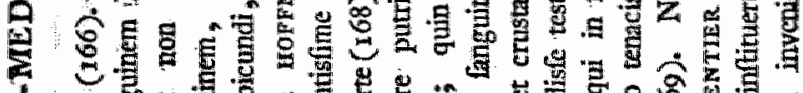

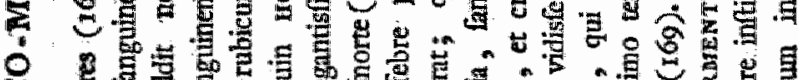

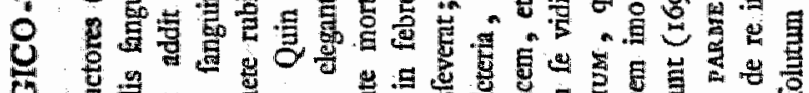

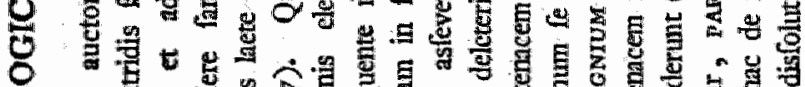

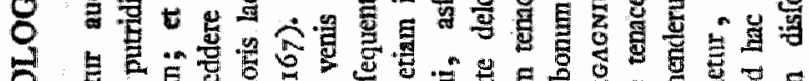

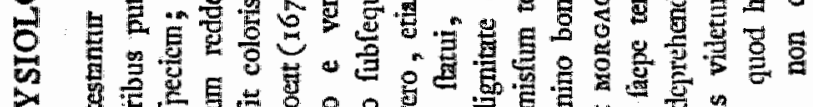

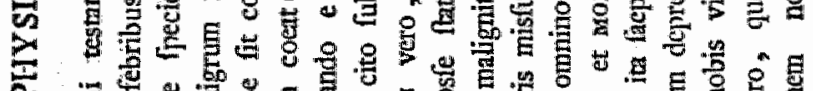

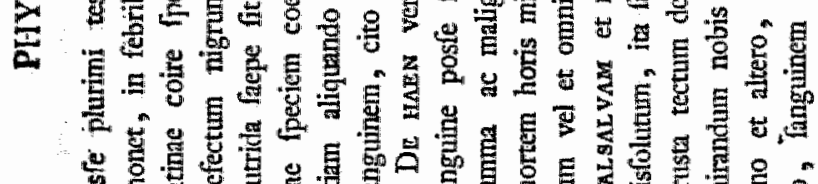

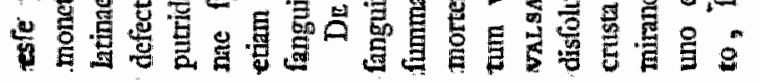

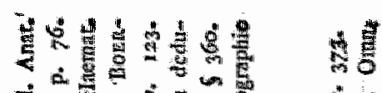

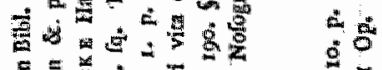
s.

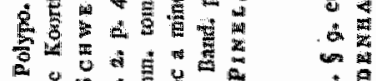

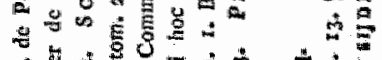

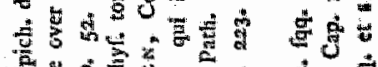

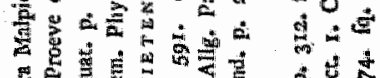

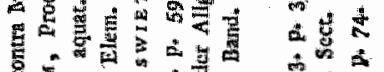

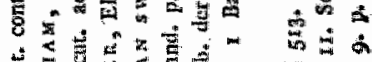

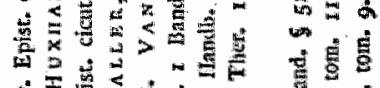

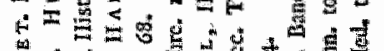

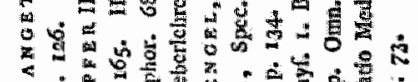

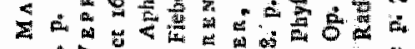

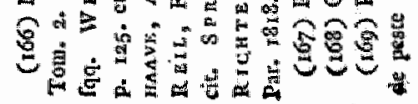

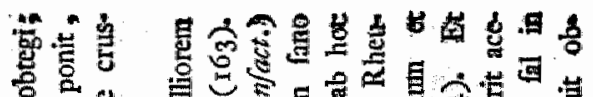

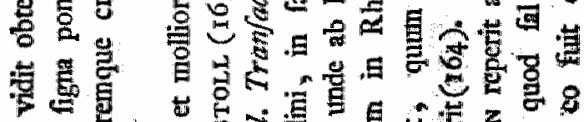
$\circ$ g

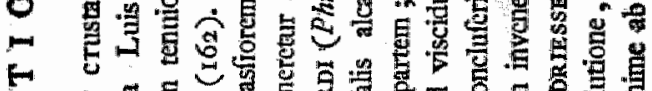

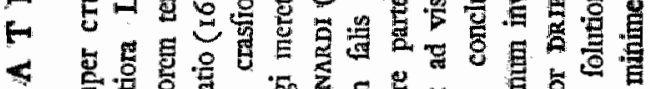

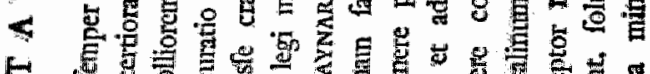

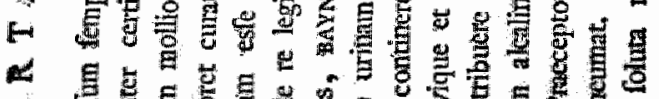

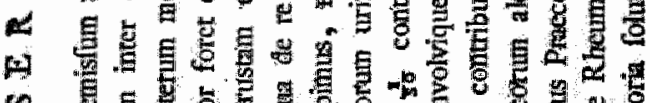
on

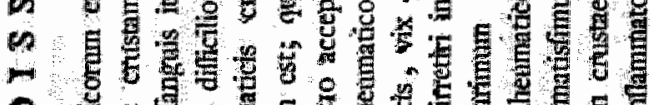
A 50

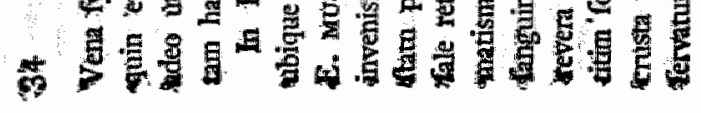

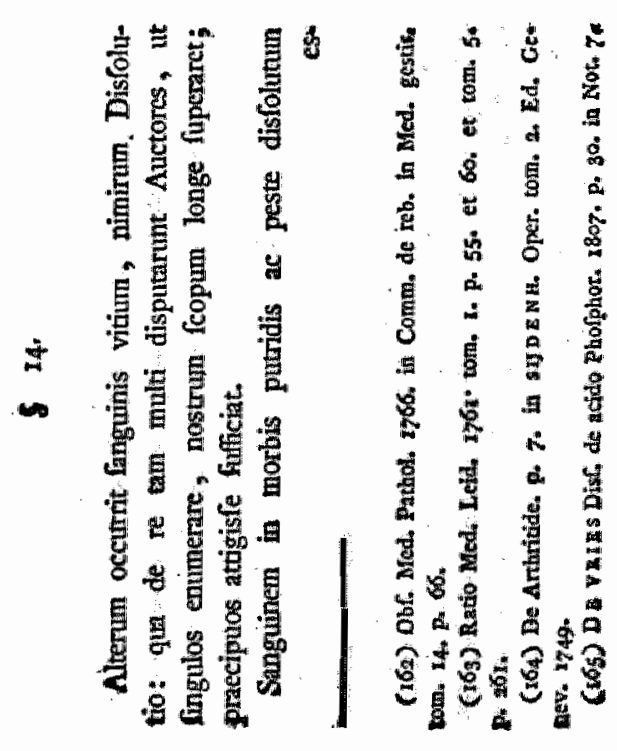


$\checkmark$ 出

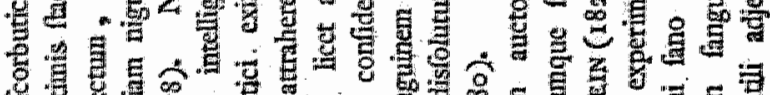

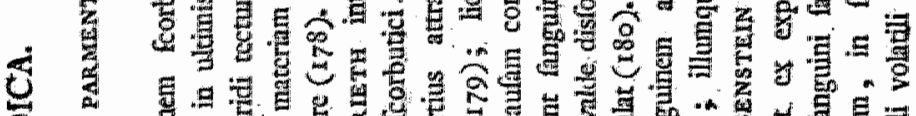

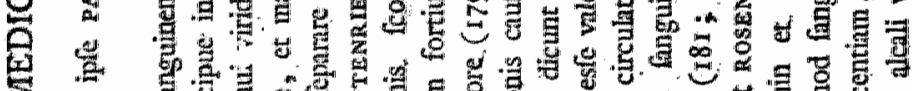

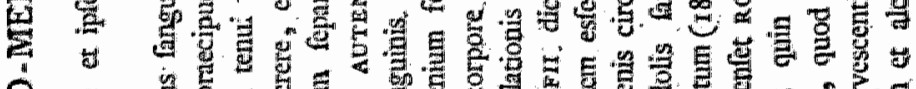

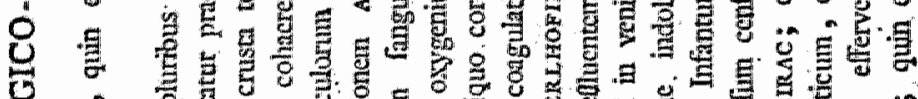

ठั

最.

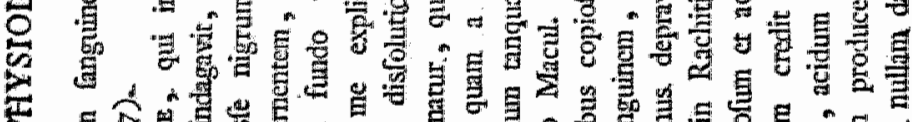
焉

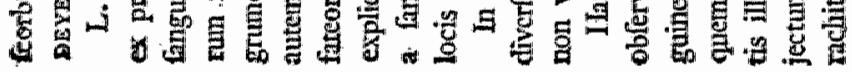

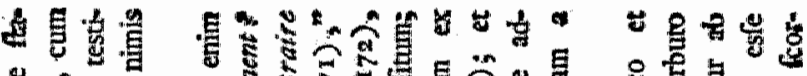

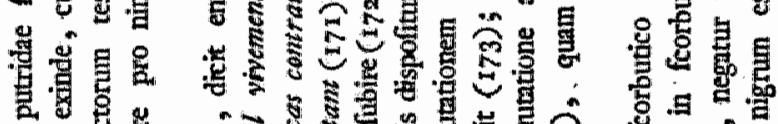

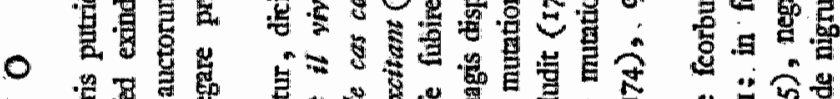

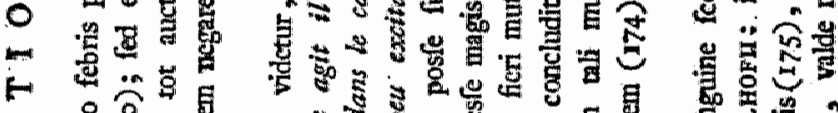

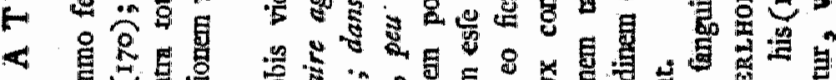

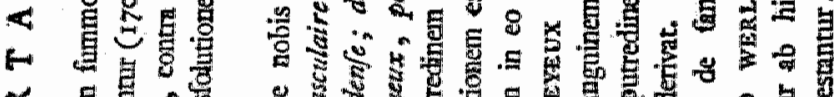

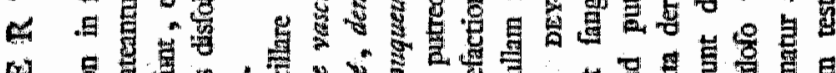

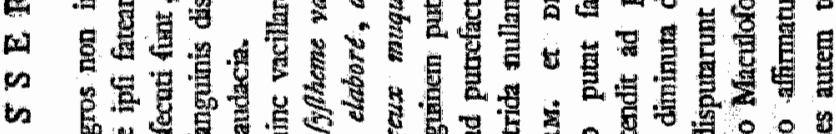

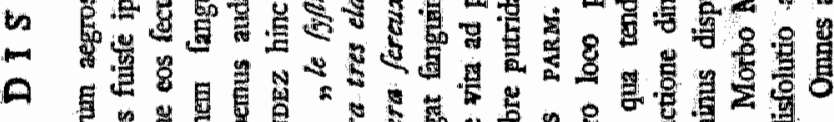

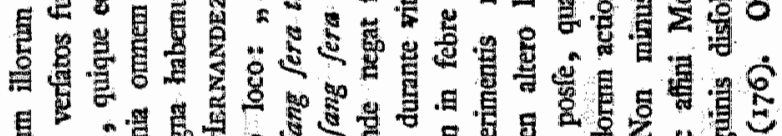

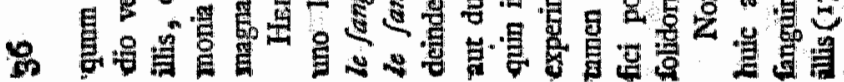

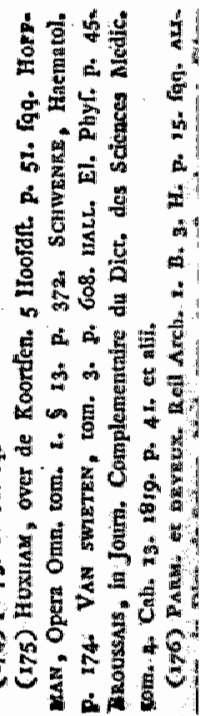


里

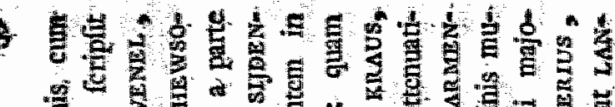

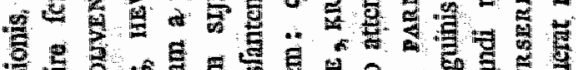

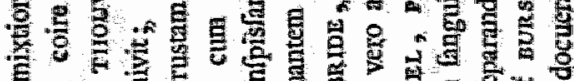

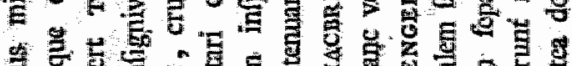

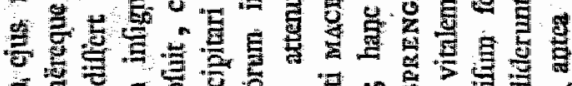

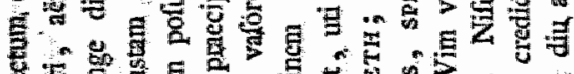

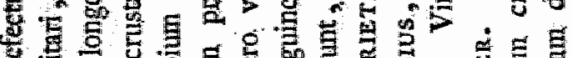

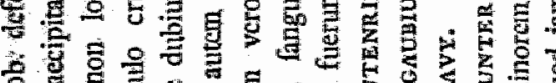

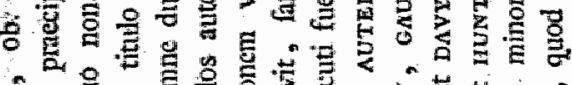

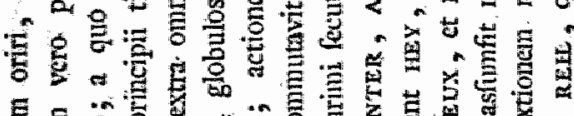

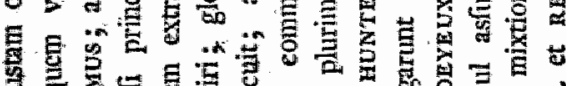

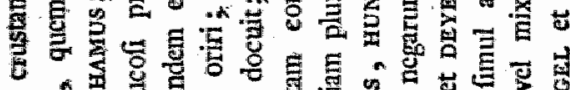

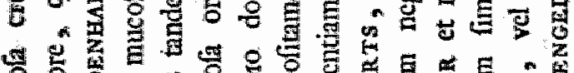

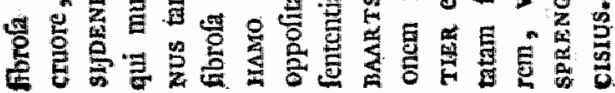

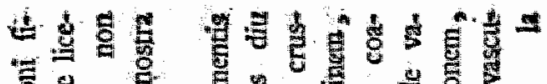

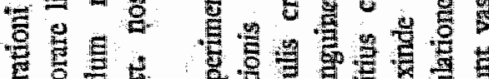

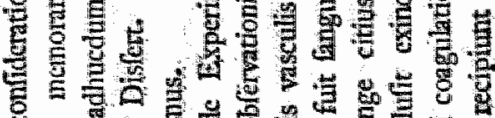

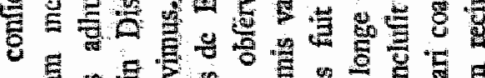

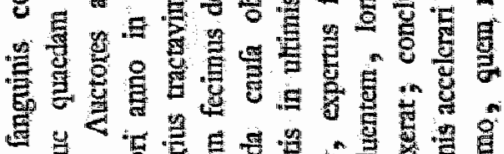

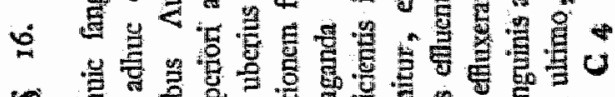

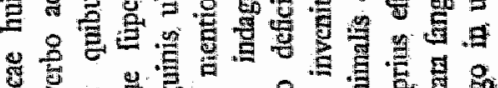

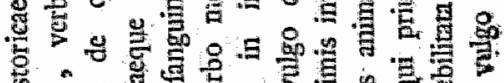

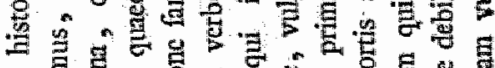

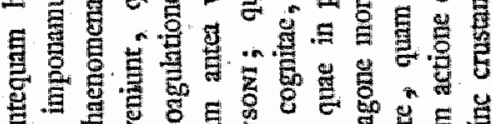

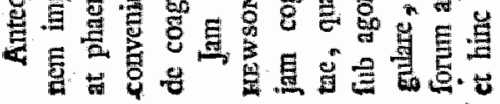

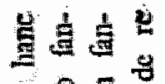
을.

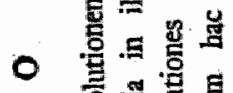

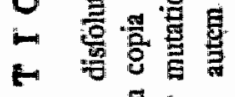

$<$ Q

- 政言

여

ه 8 害

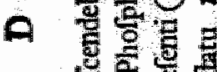
흫 호음 g. 를

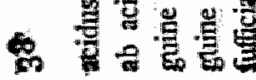

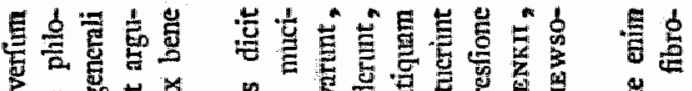

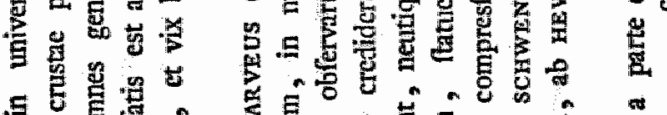

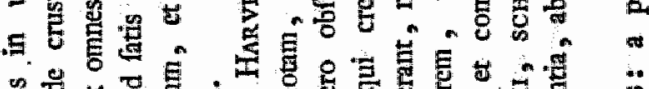

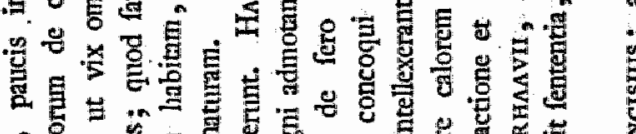

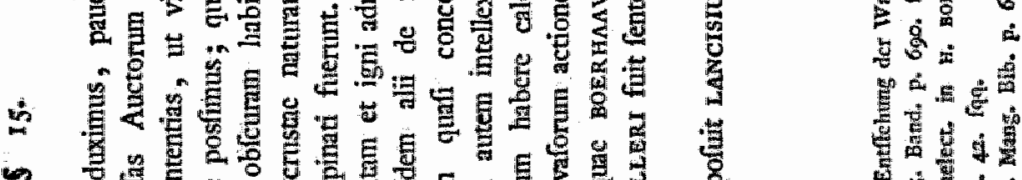

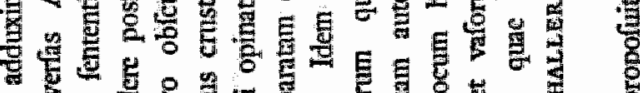

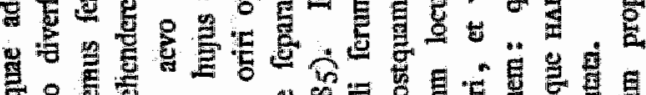

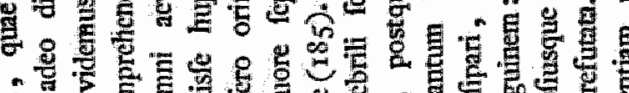

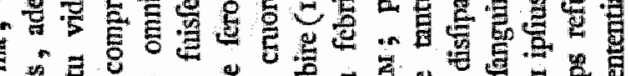

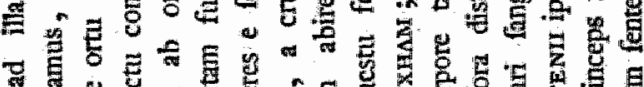

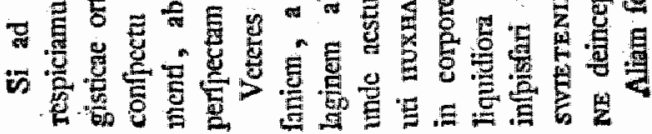

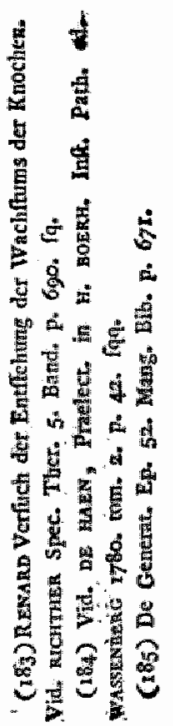




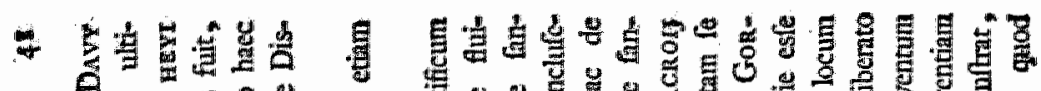

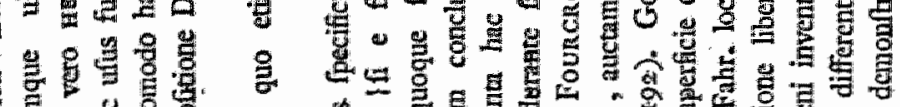

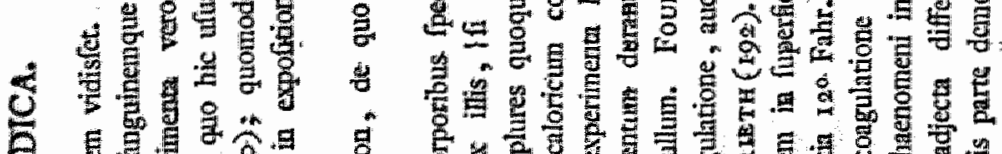

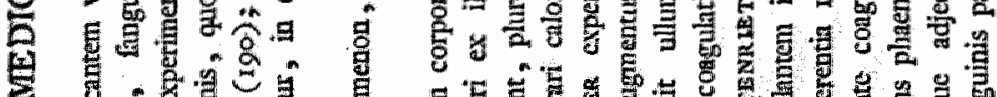

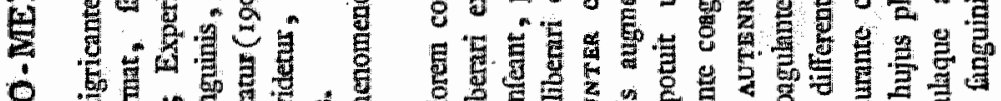

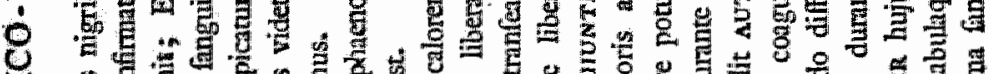

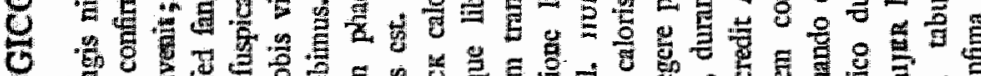

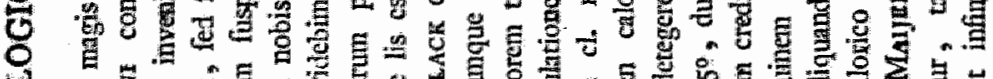

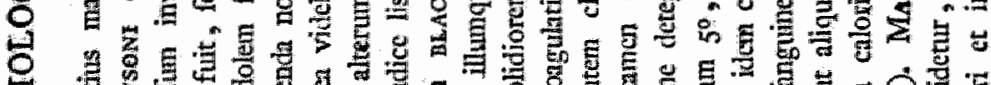
品

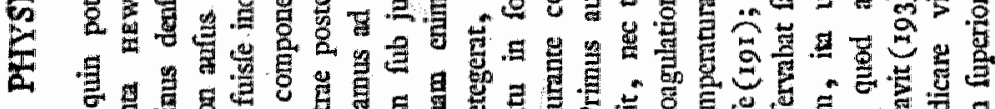

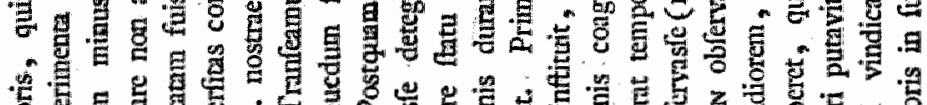

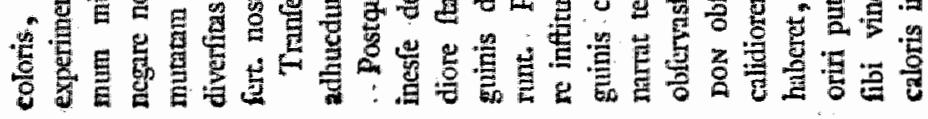

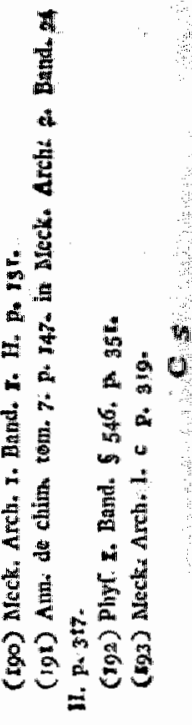

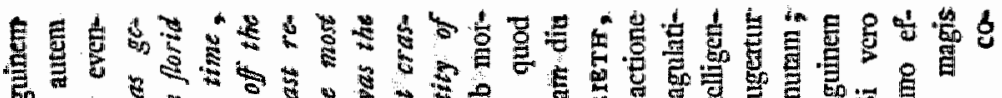

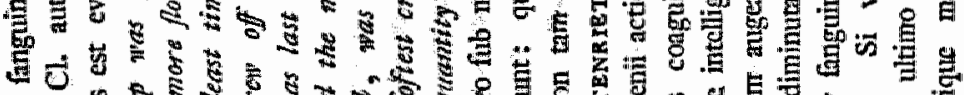
0
0

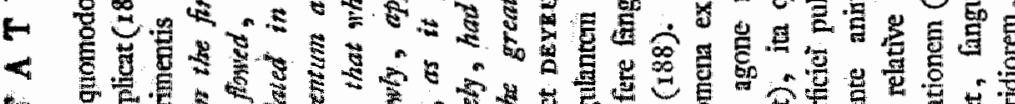
-

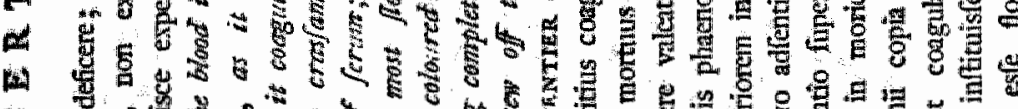

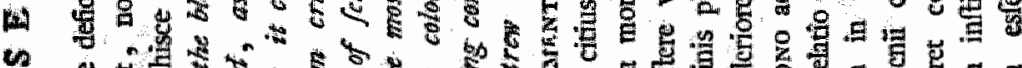

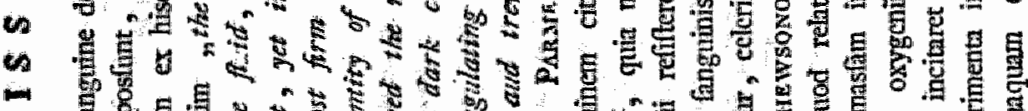

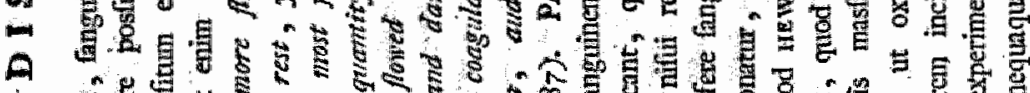

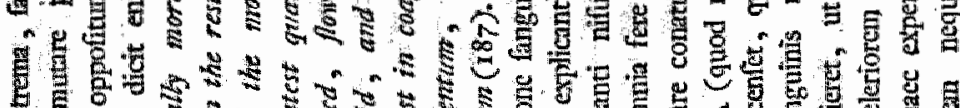

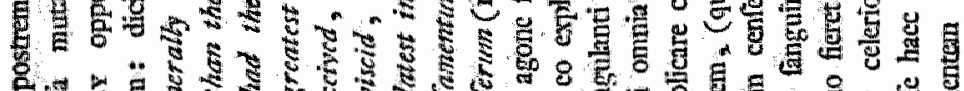

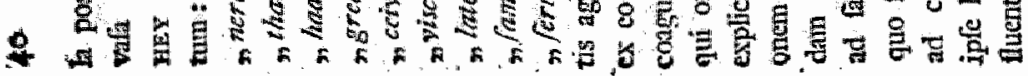

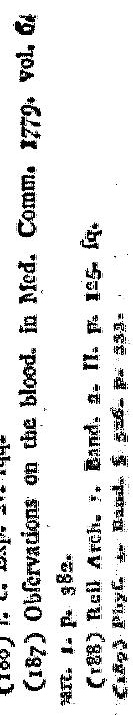




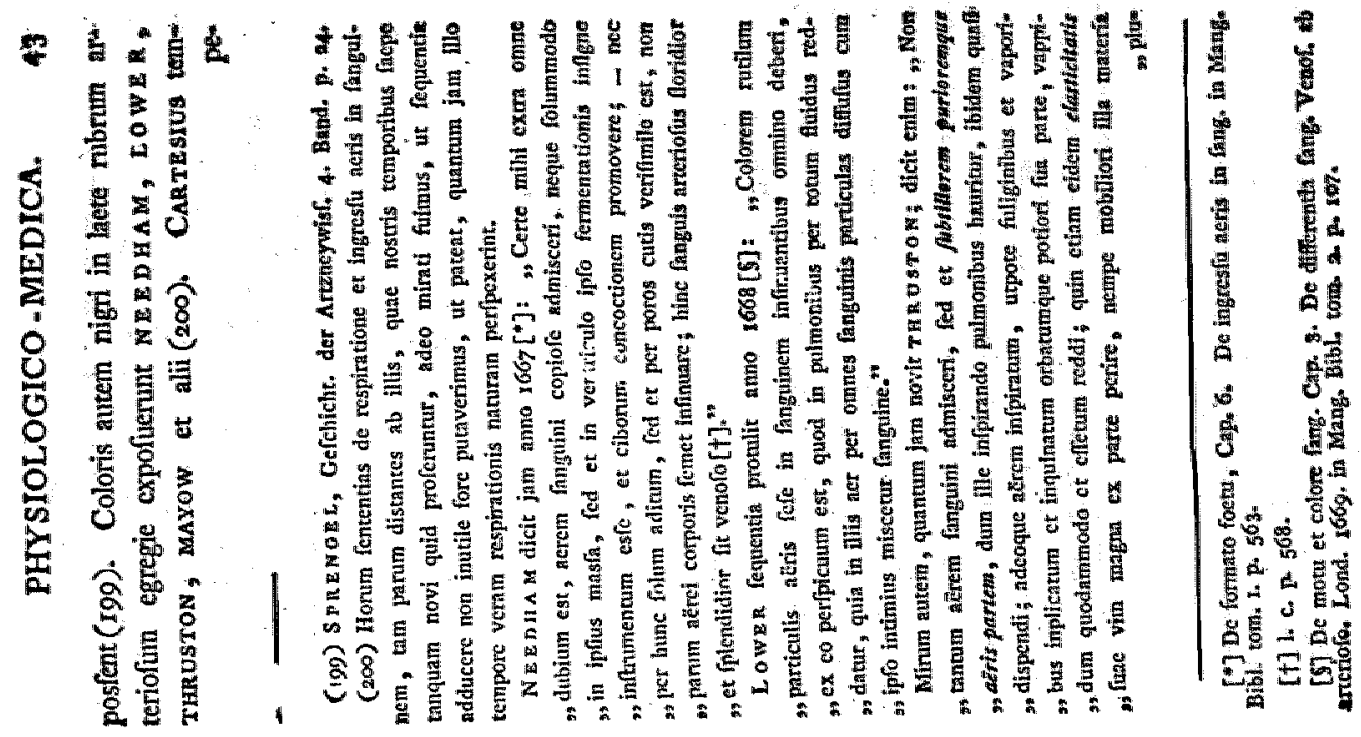

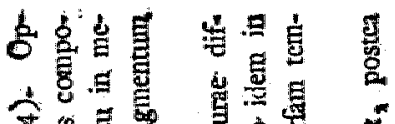

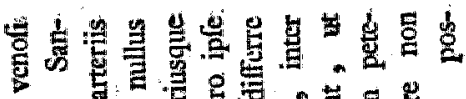

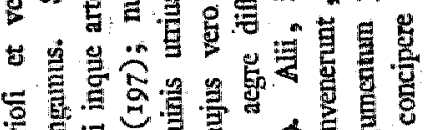

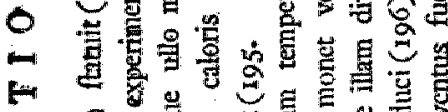

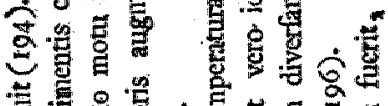

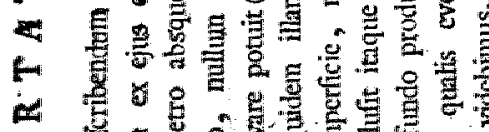
क क
2 들

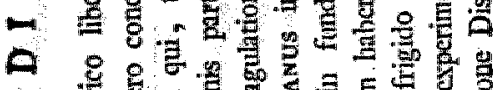

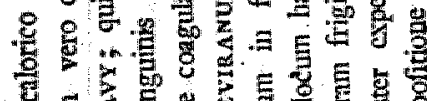

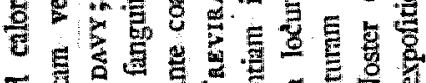

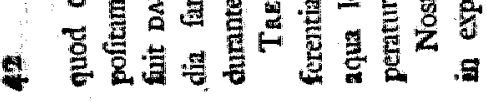

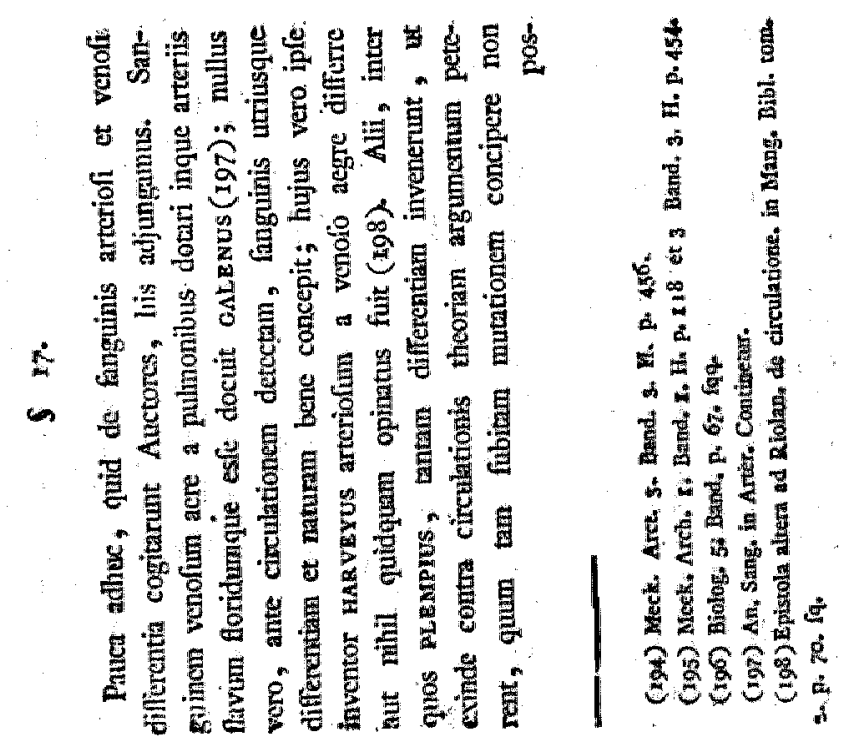



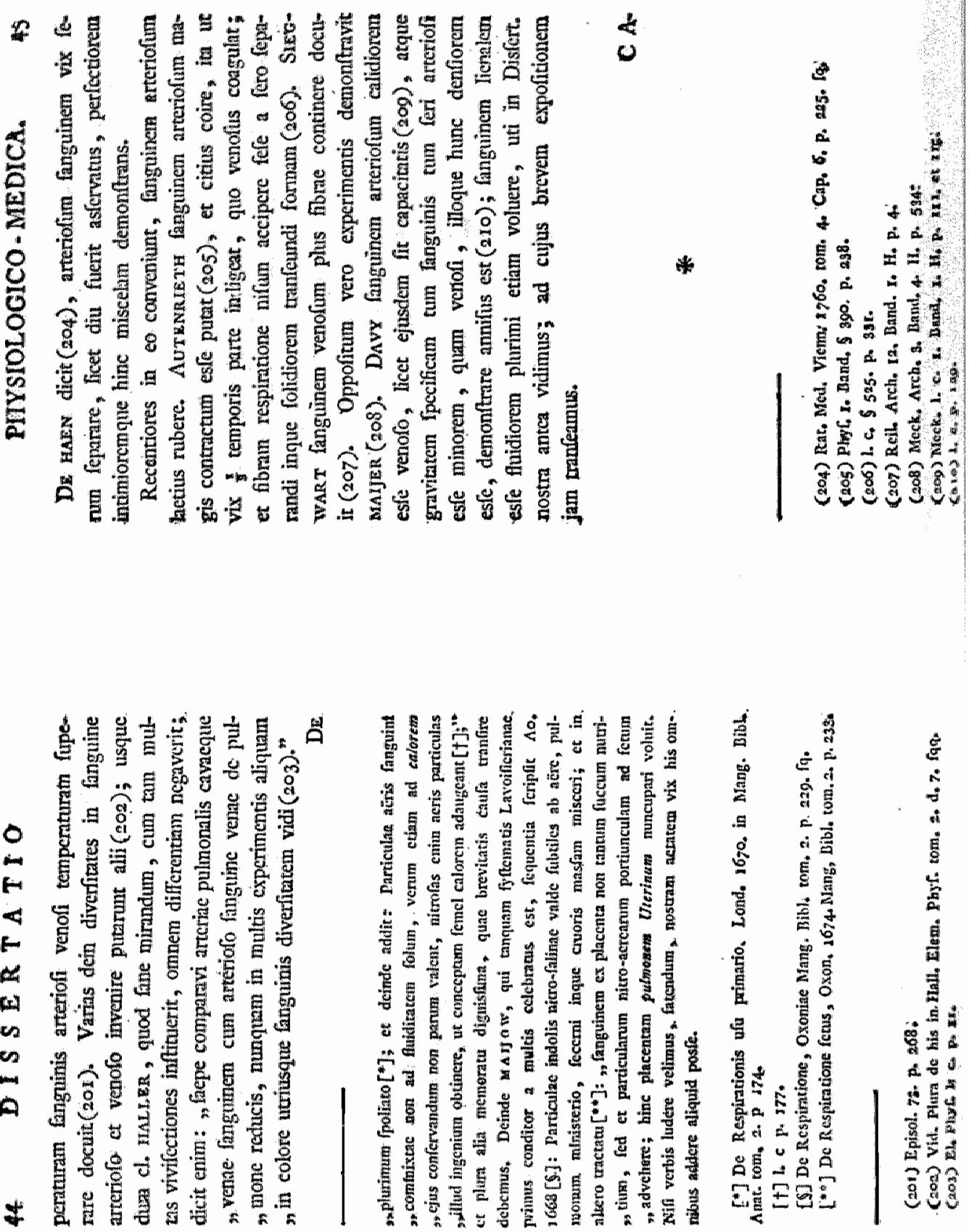


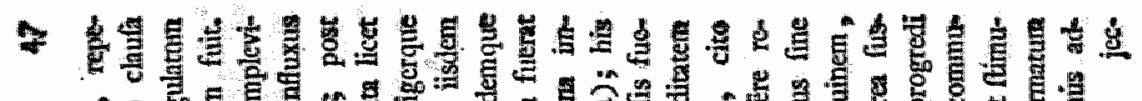

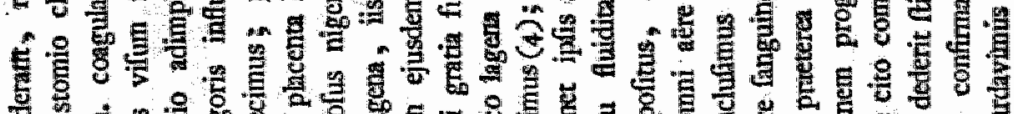

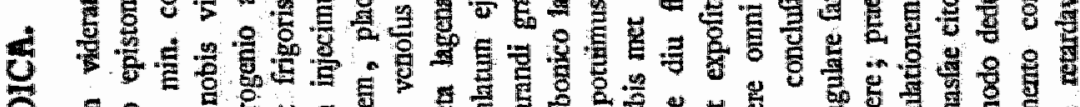

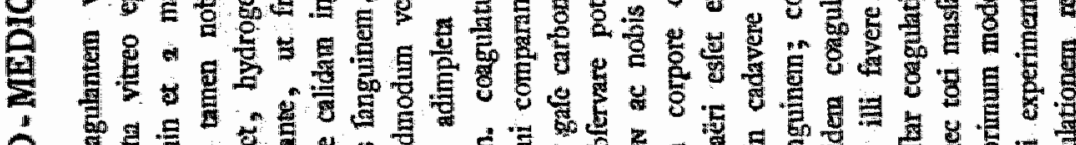

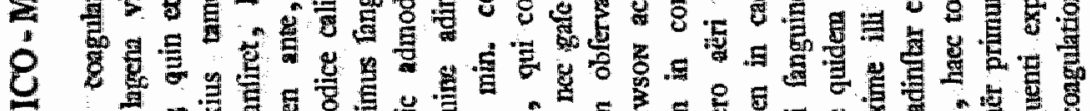
万人

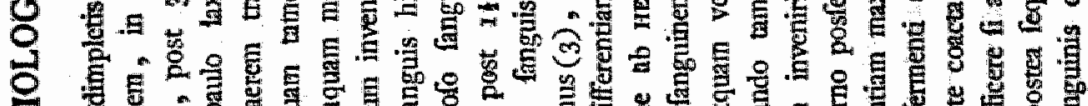

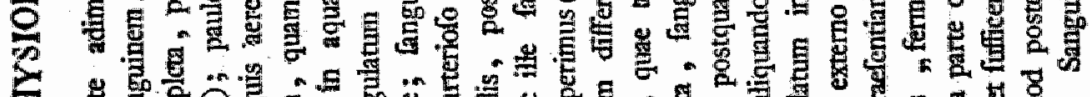
至

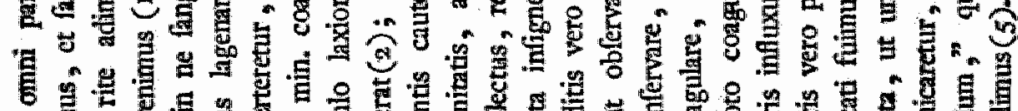

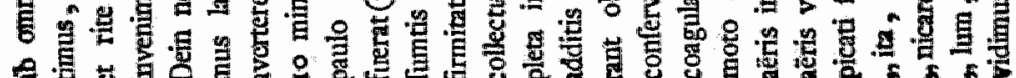

2

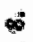

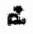

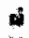

\#

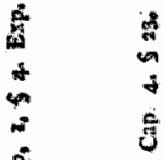

हैं.

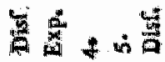

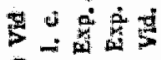

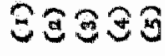

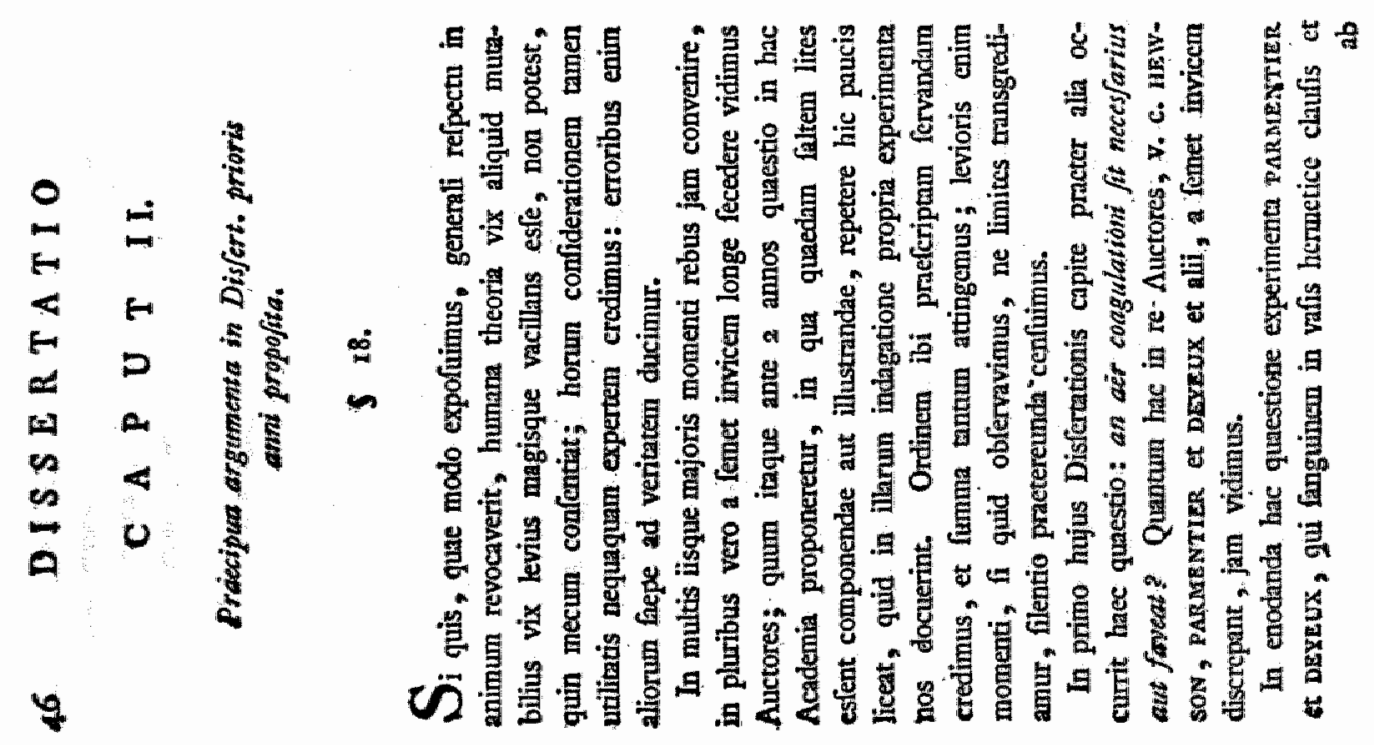




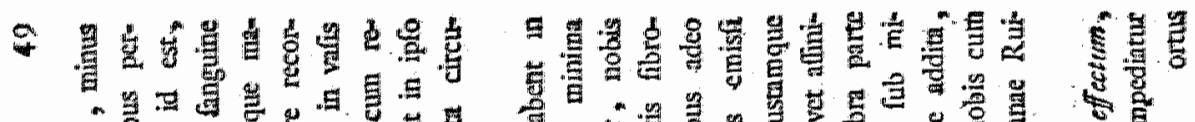

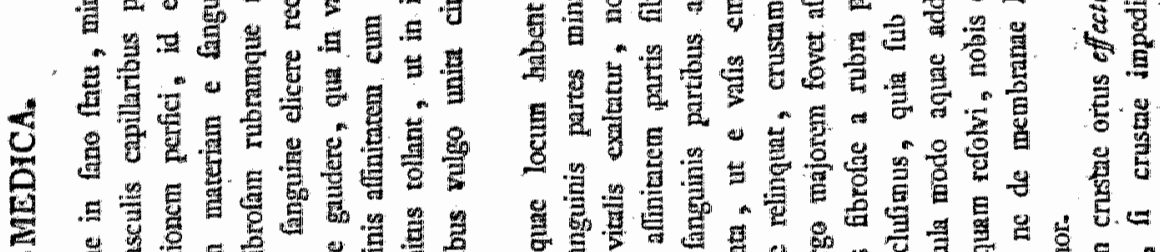

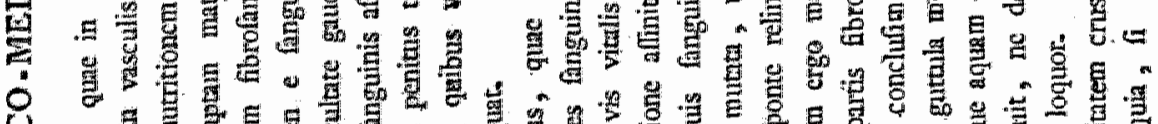
O

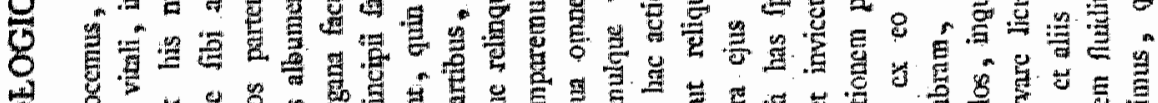

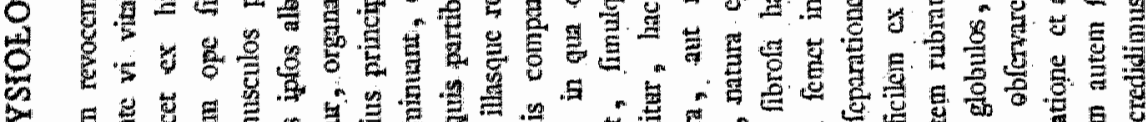

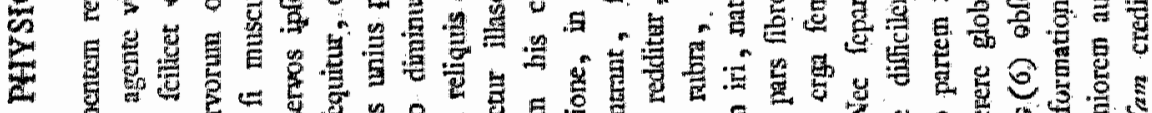

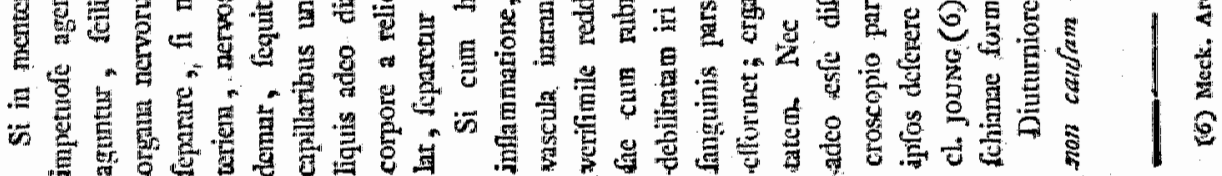

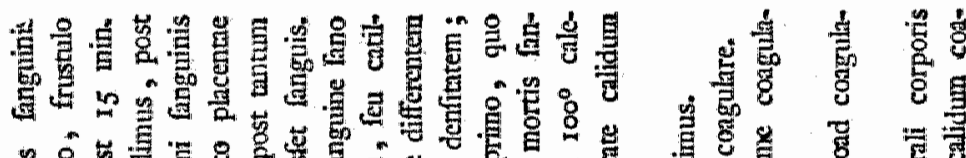

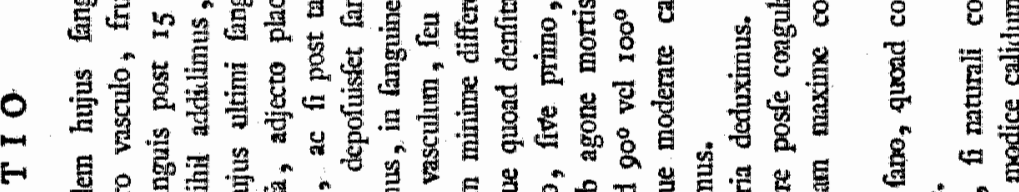

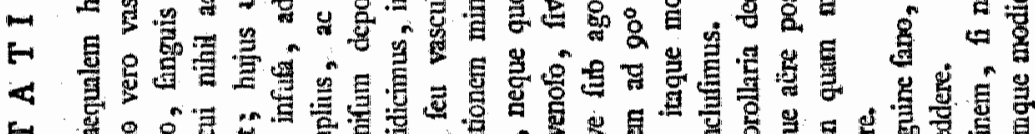
F

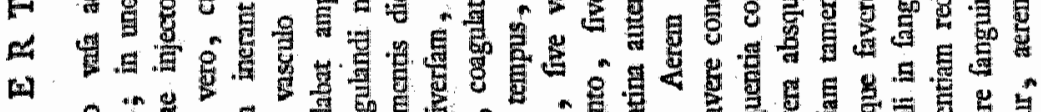
w

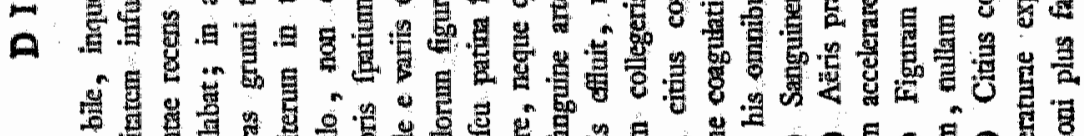

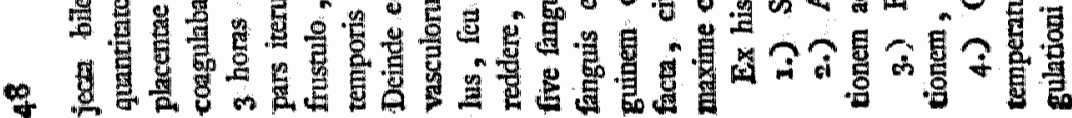

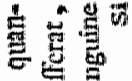

-

-

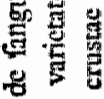

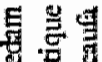

क

ए

85

Q

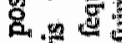

is

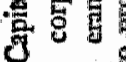

co 9

0 


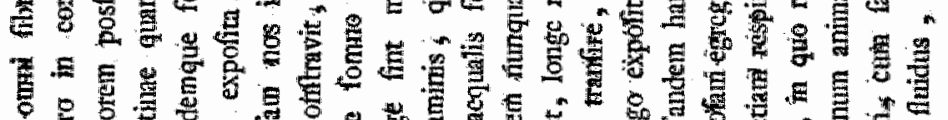

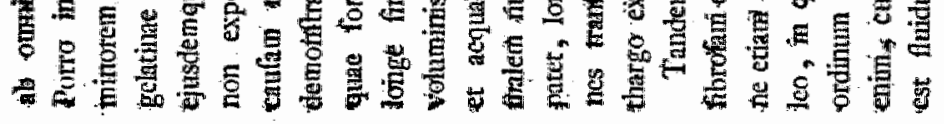

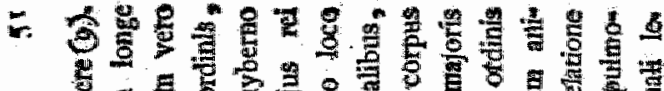

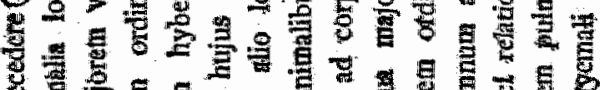

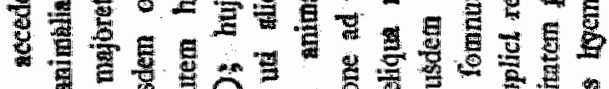

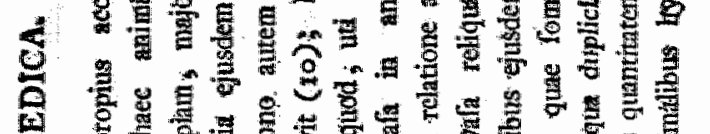

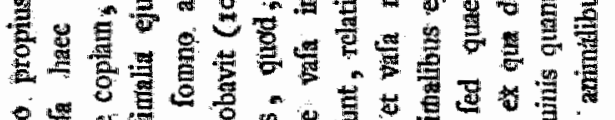

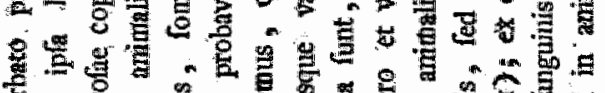

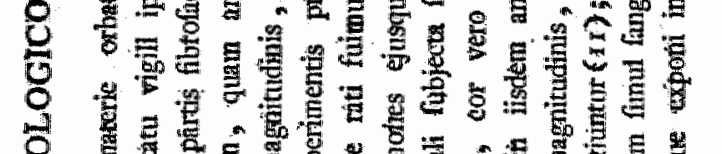

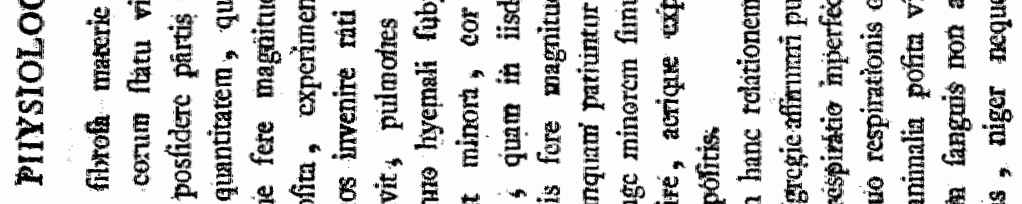

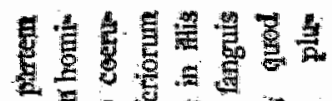

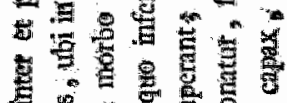

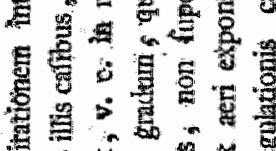

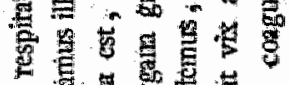

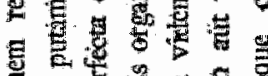

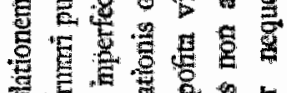

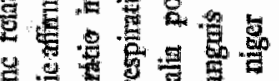
.

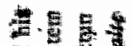

裉

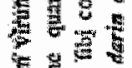

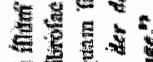

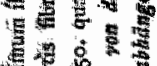

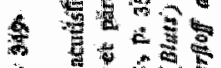

\&

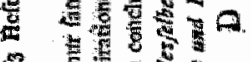

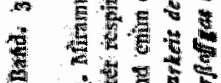
4.

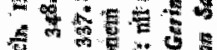

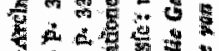
舟

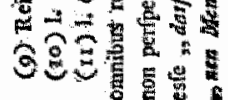

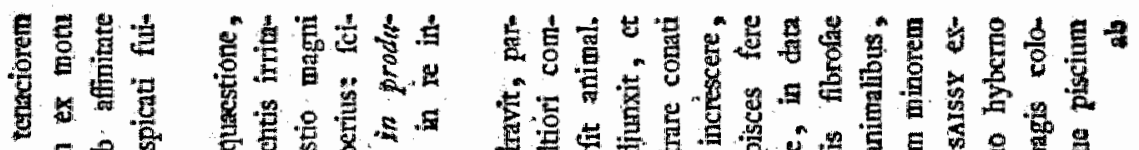

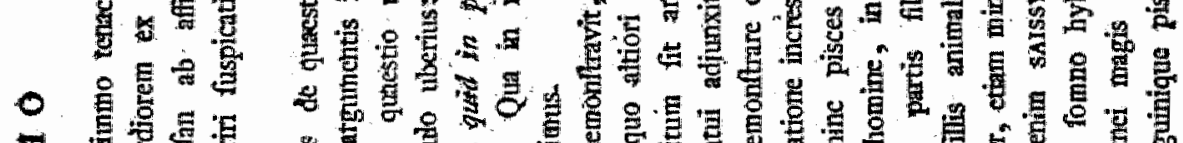

- 点总员

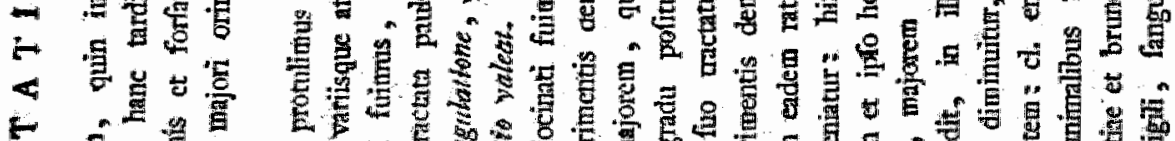

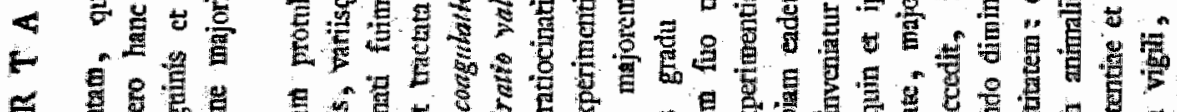

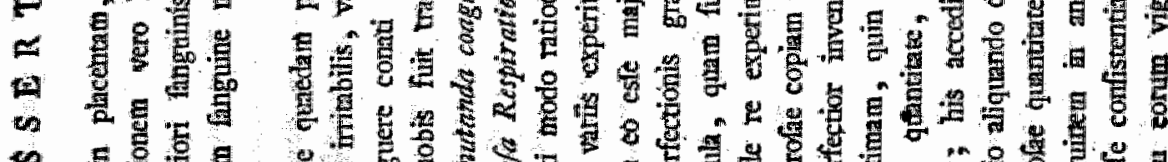

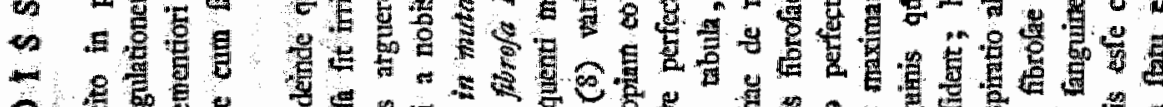

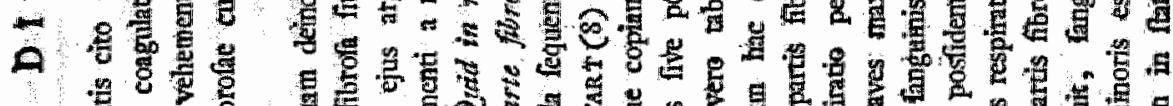

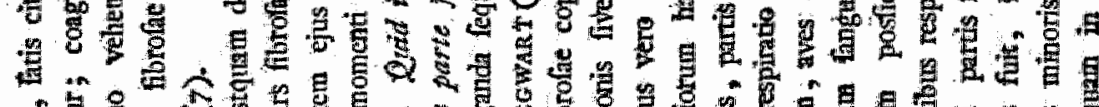

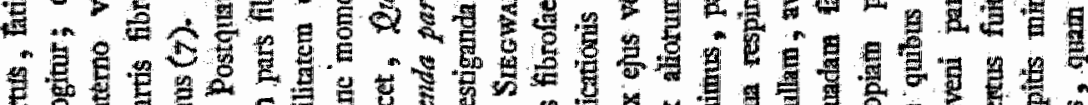

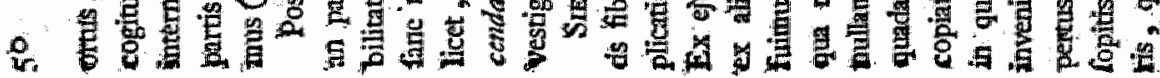




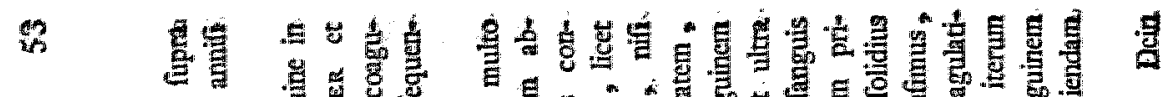

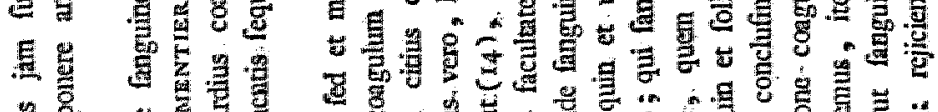

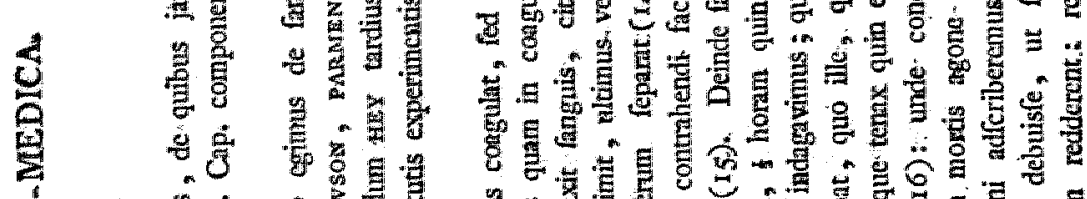
导 d

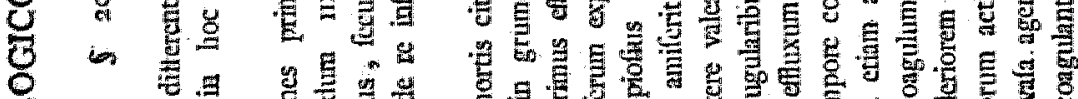
O

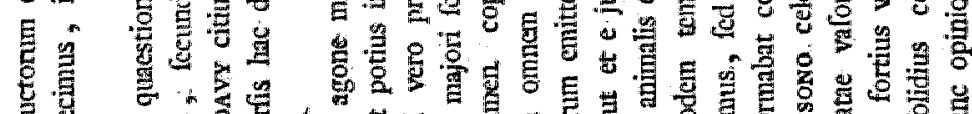

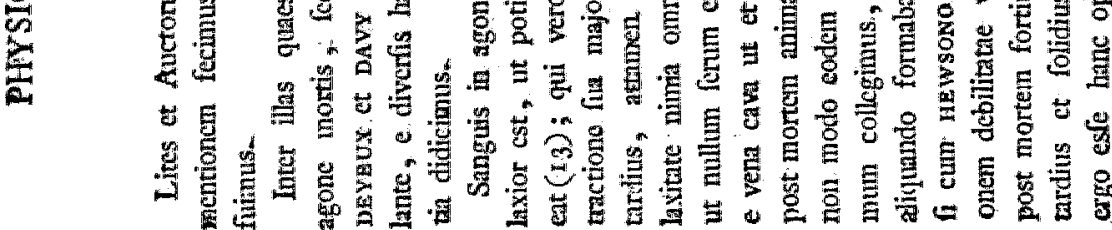

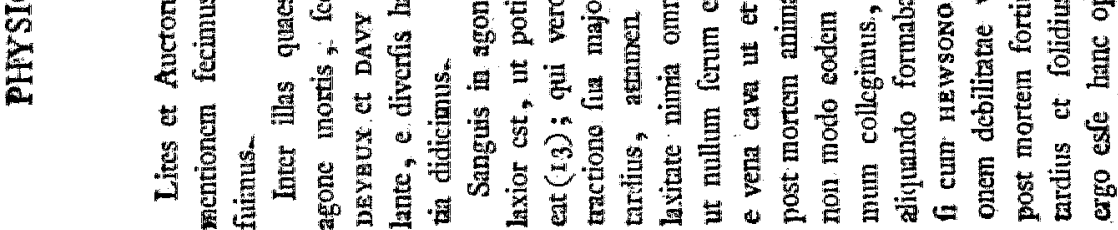

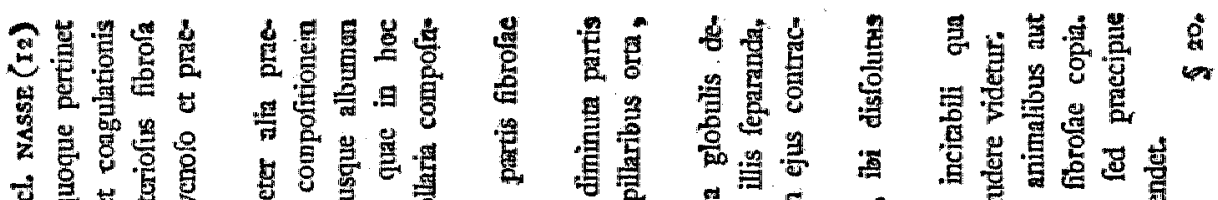

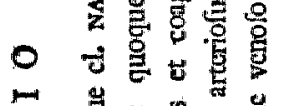

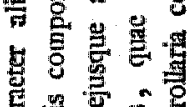

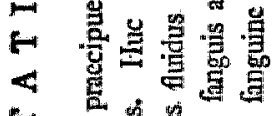

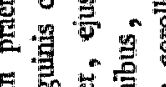

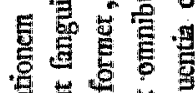

I

a is

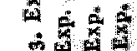

को is

- -7

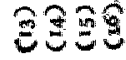




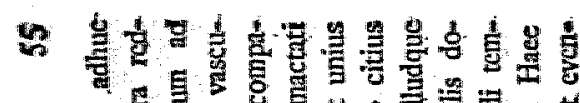

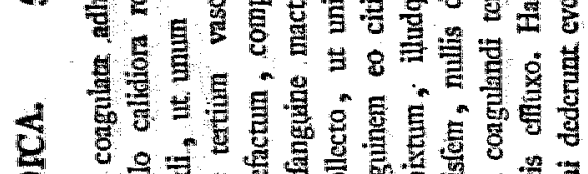

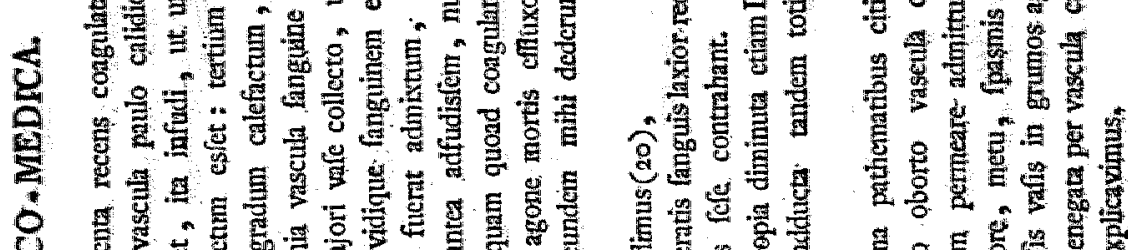

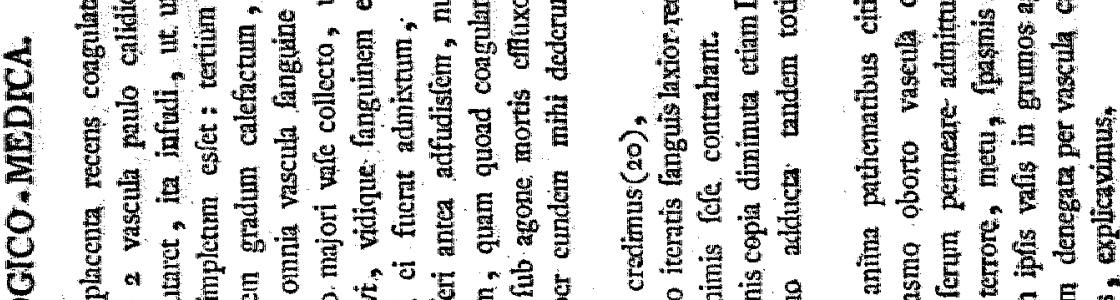

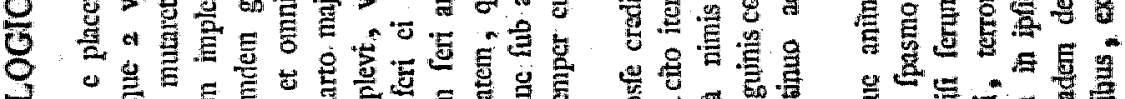

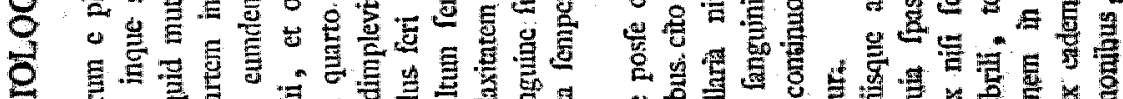

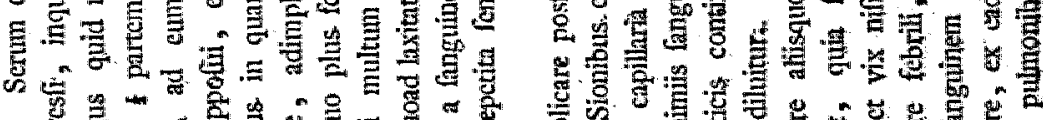

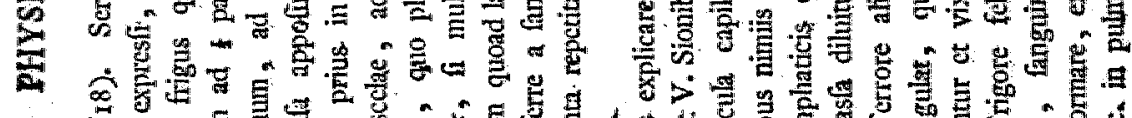

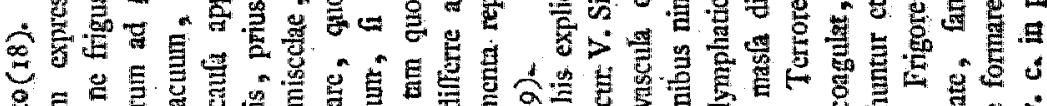

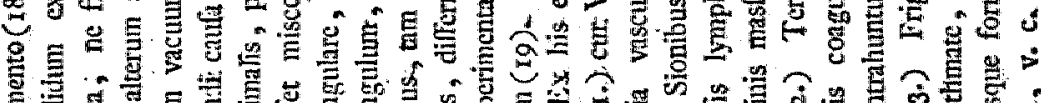

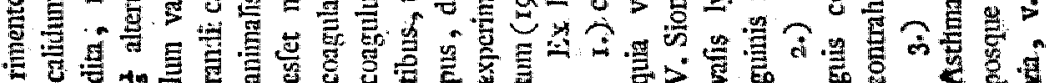

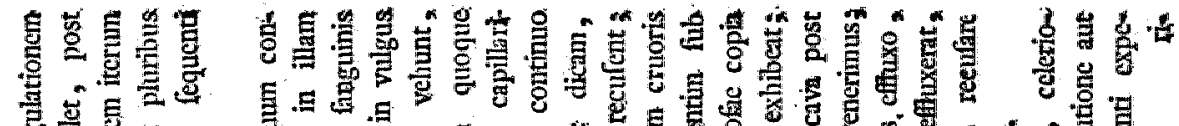

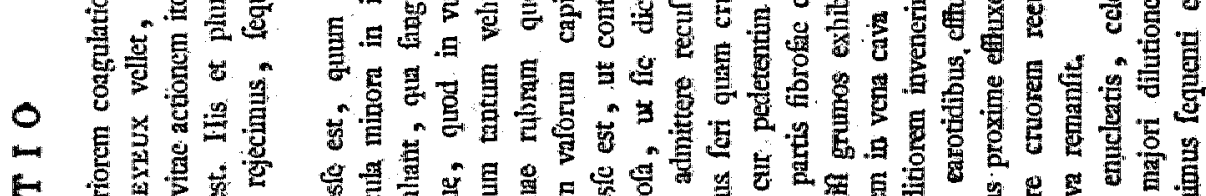

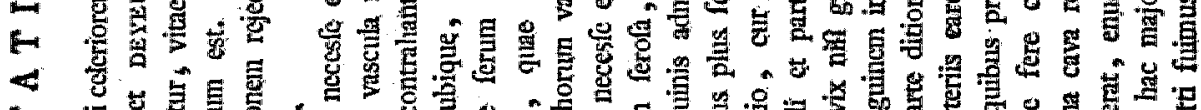

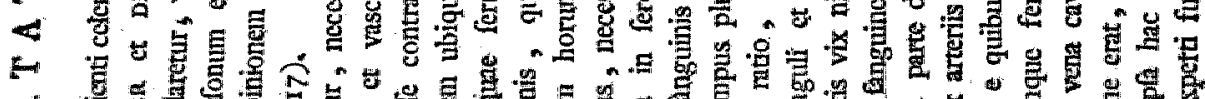

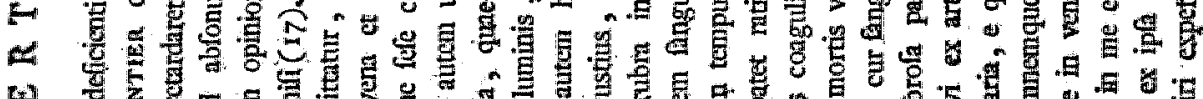

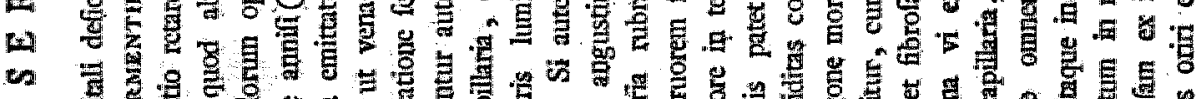

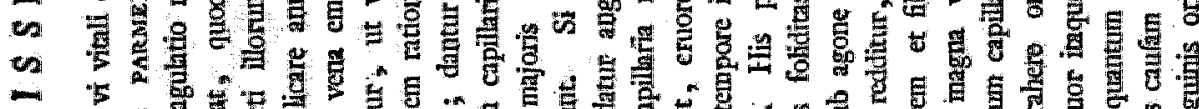

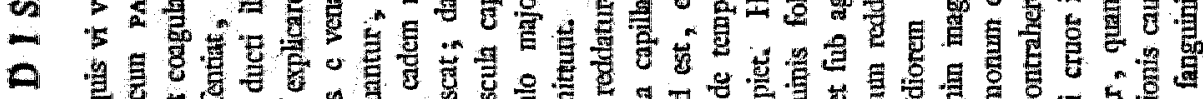

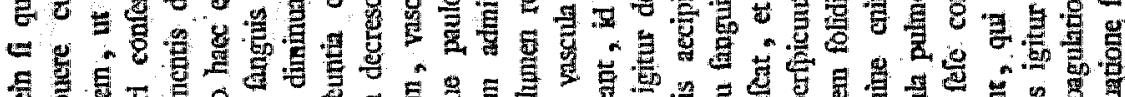

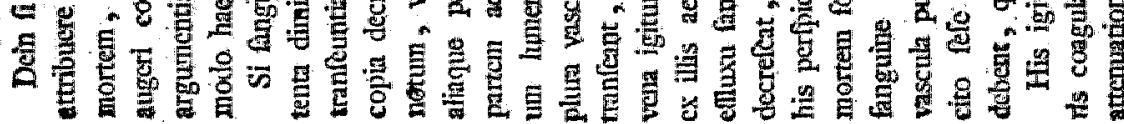




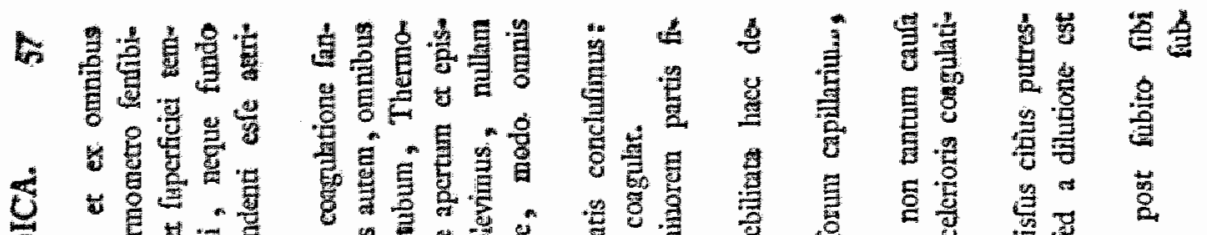

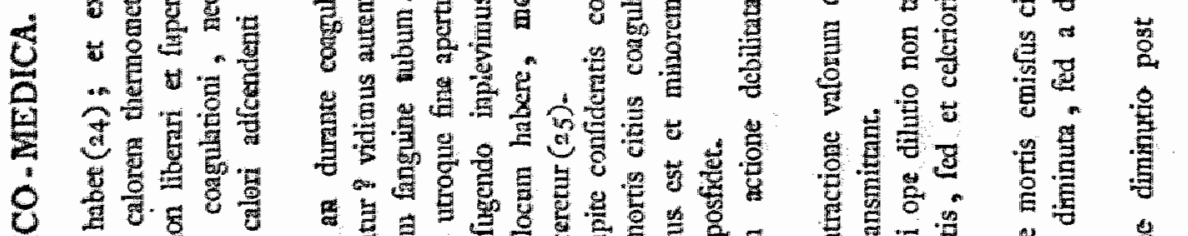

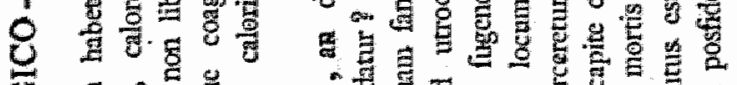

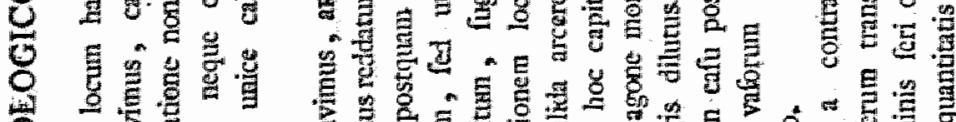

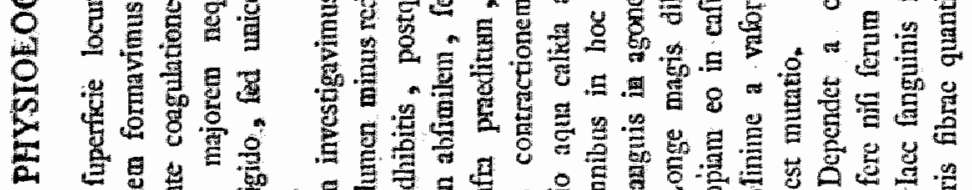

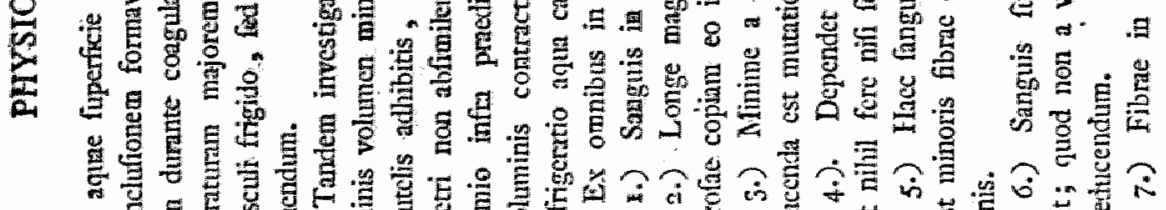

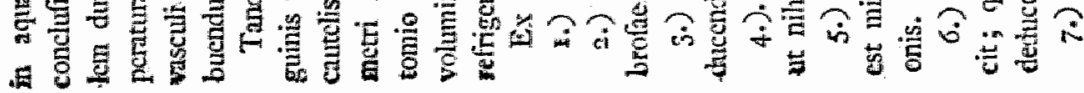

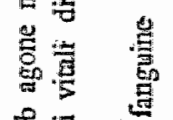

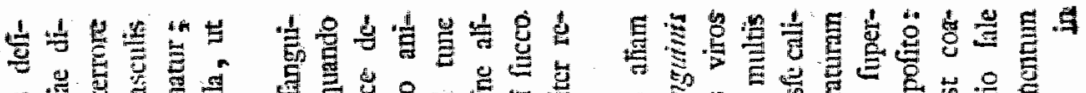

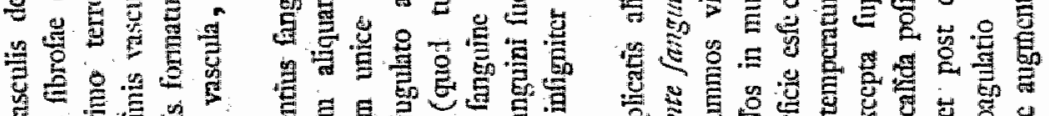

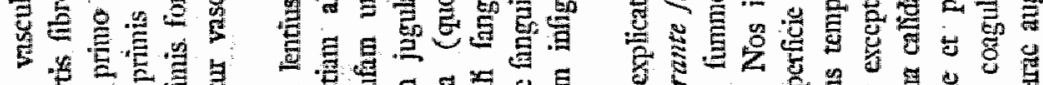

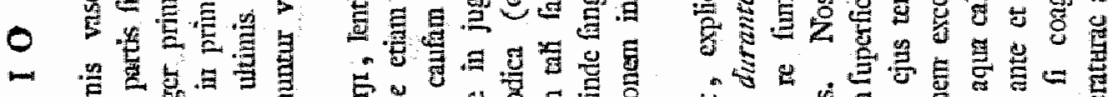

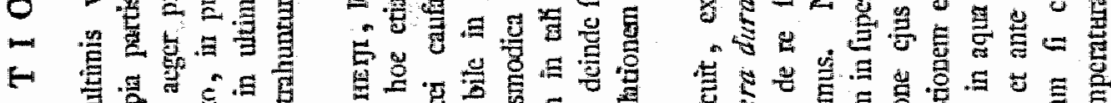

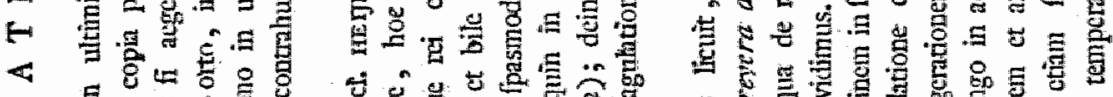

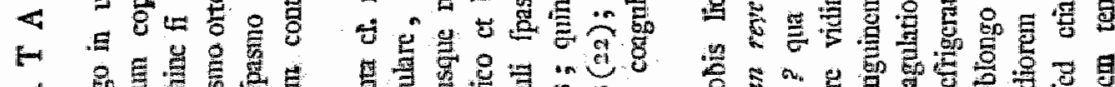

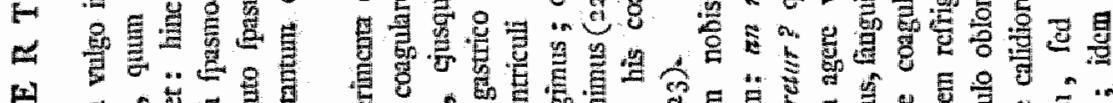
* m

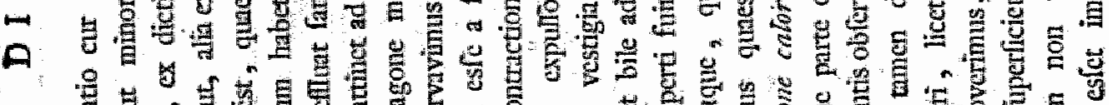

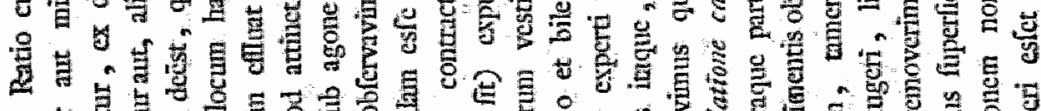

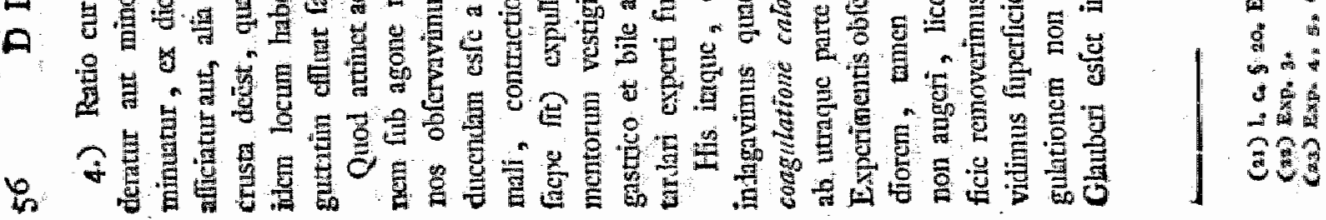




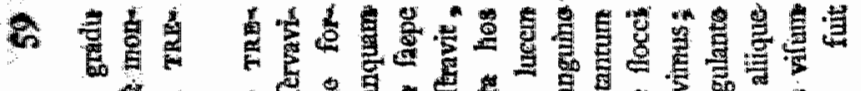

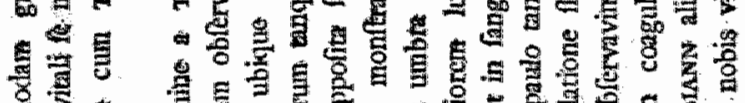

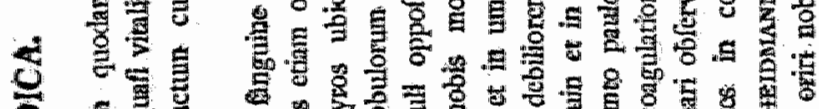

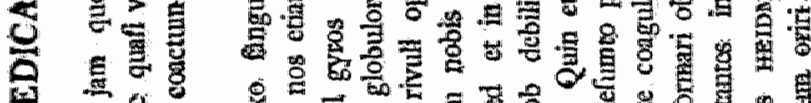

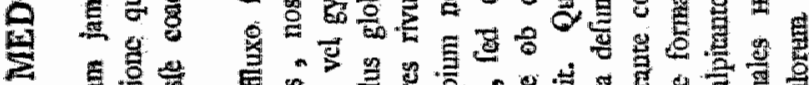

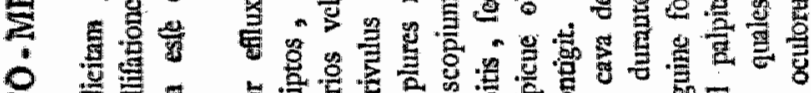

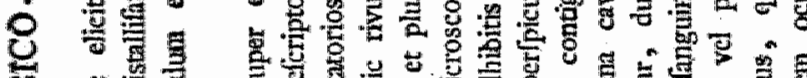

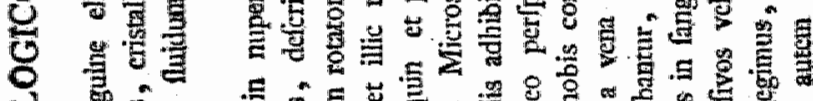

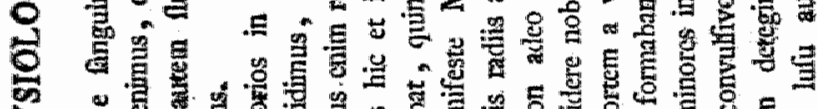

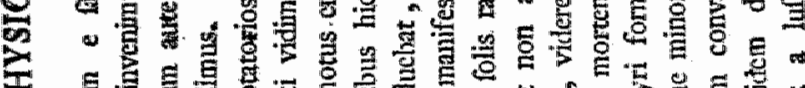

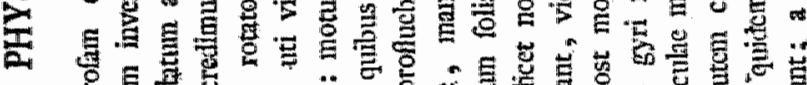

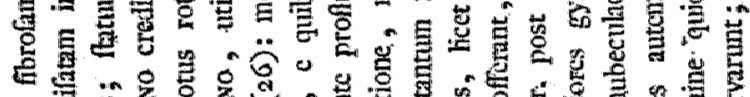

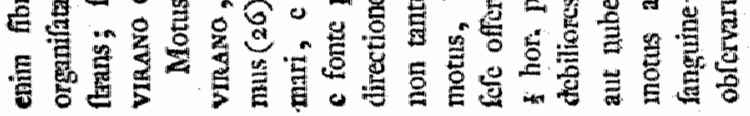

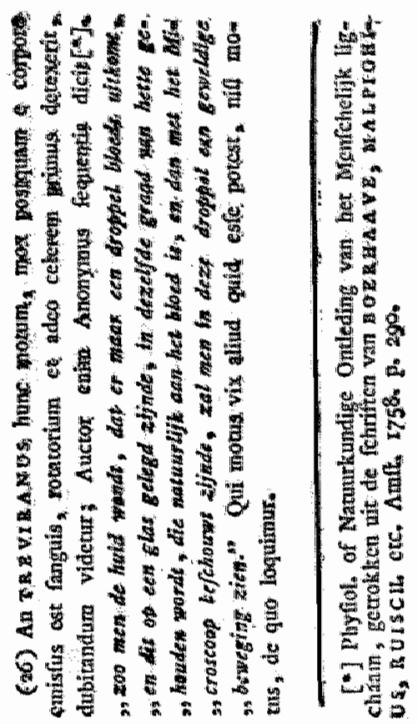

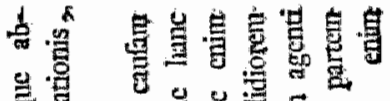

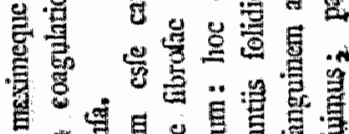

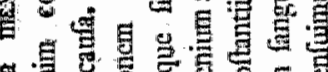

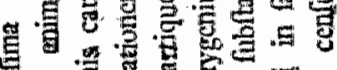

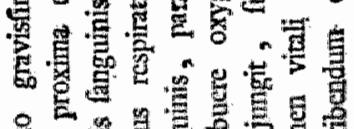
ส

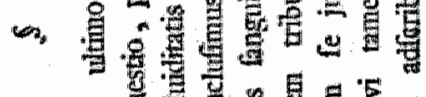

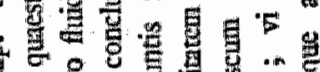

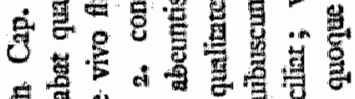

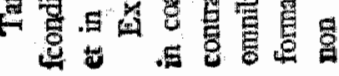




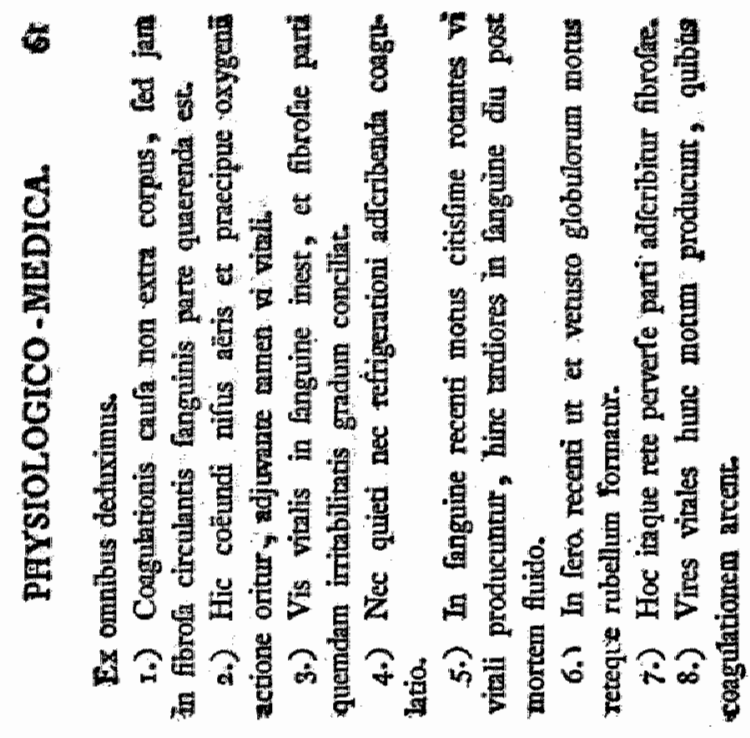

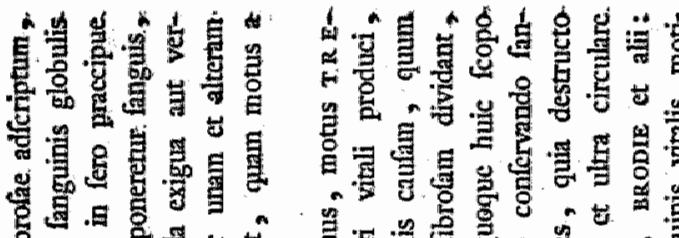

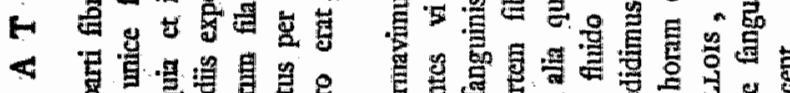

4

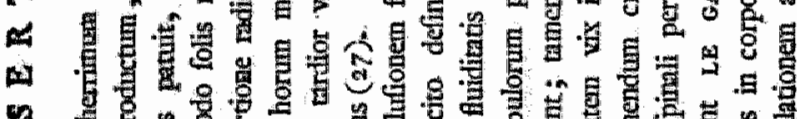

m

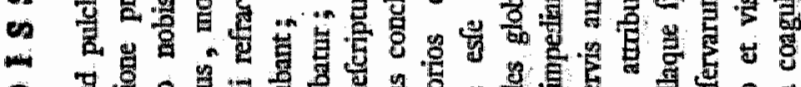

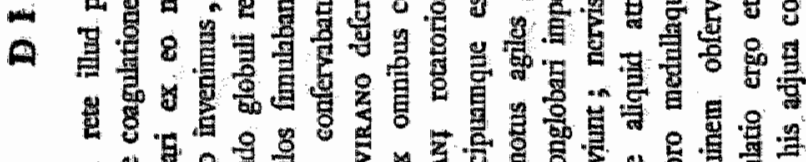

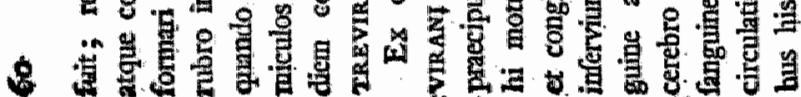

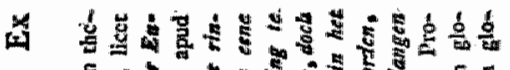

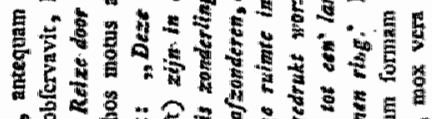

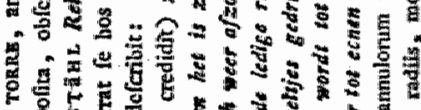

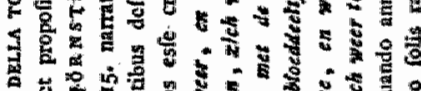

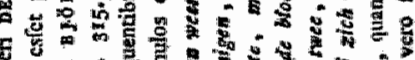

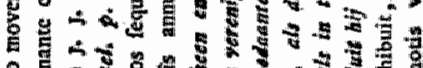

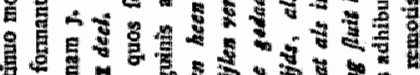

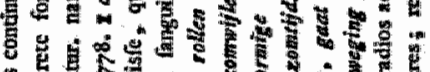

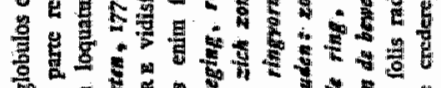

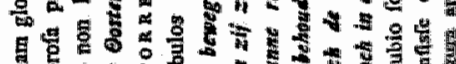

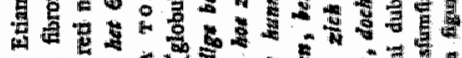
生结

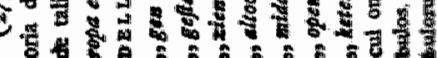




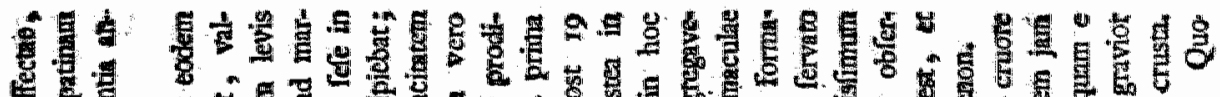

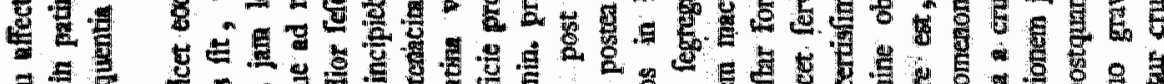

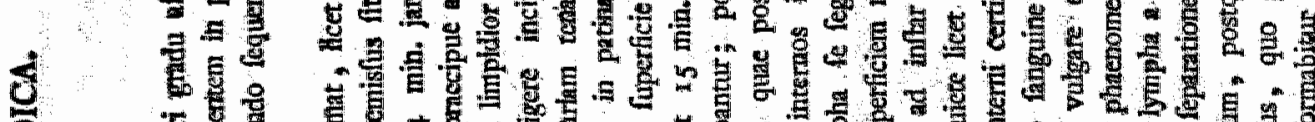

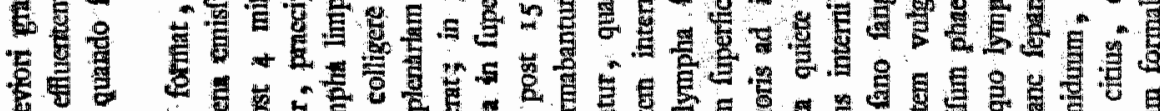

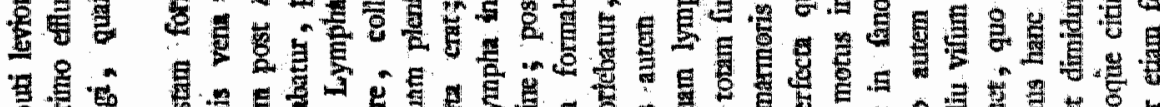

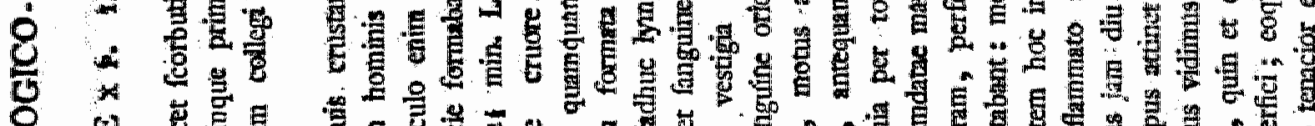

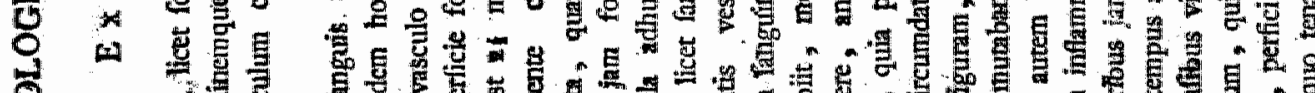
늘

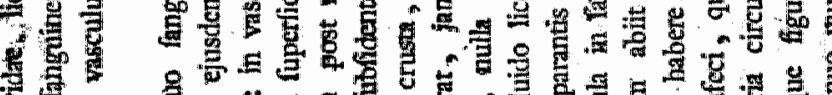

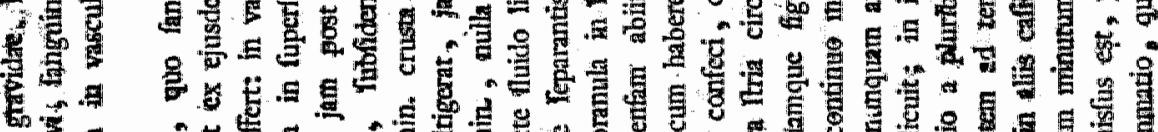

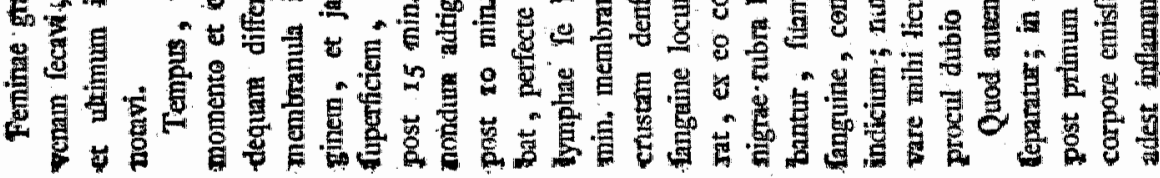

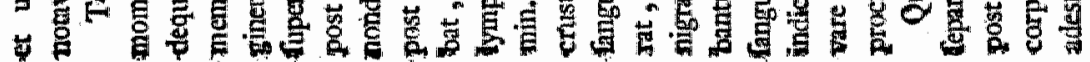

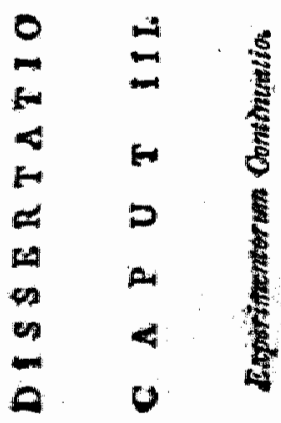

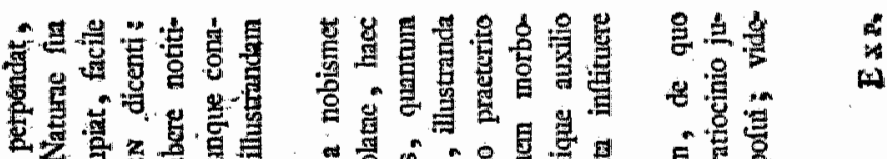

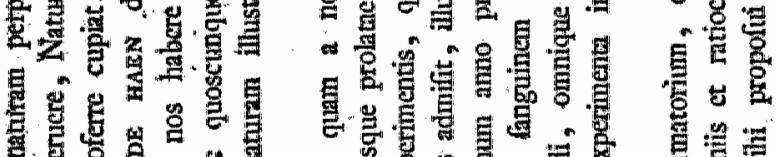

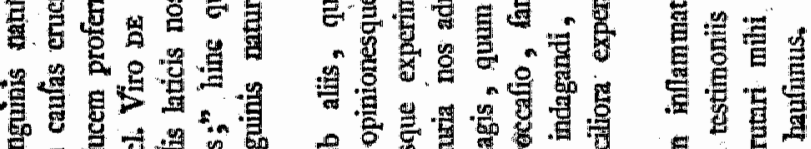

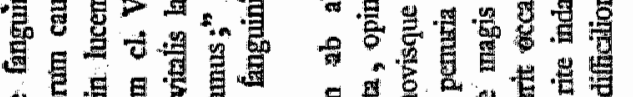

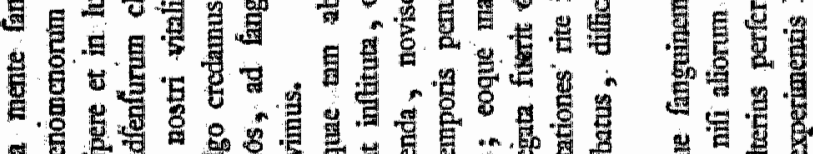

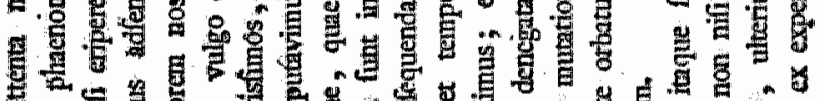
क

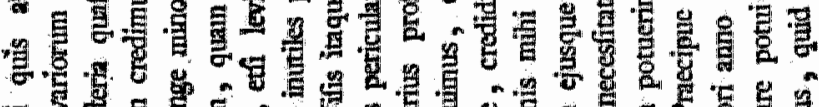

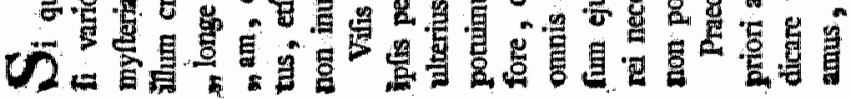




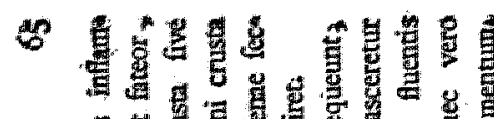

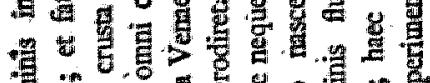

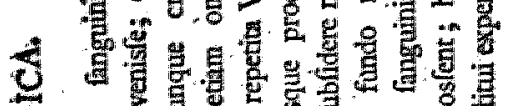

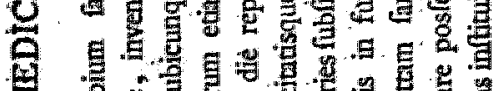

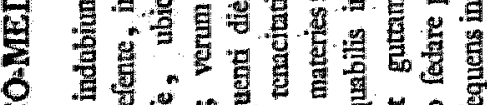

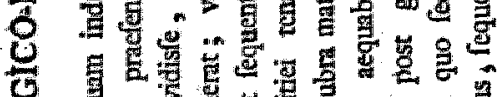

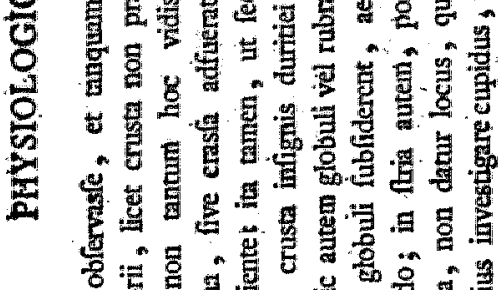

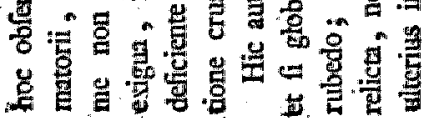

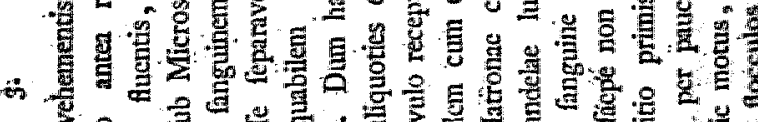

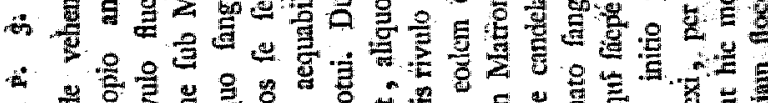

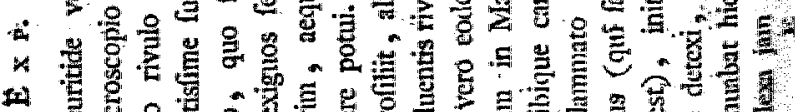

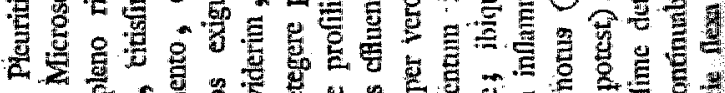

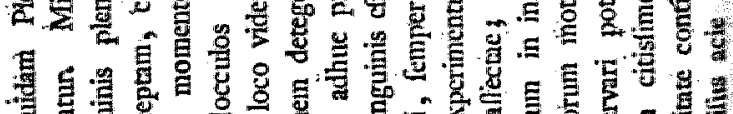

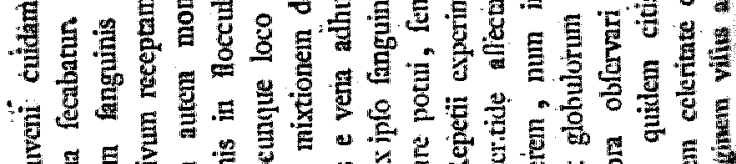

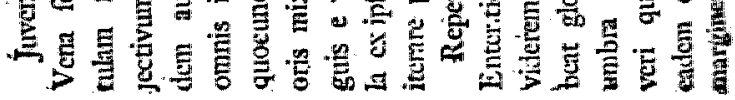

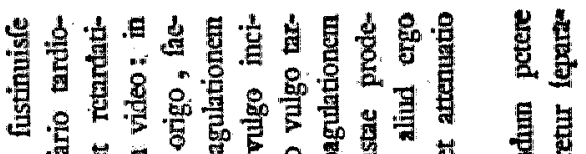

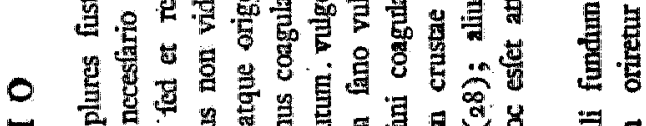

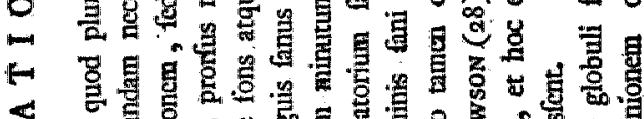

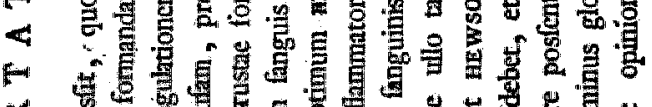
\%

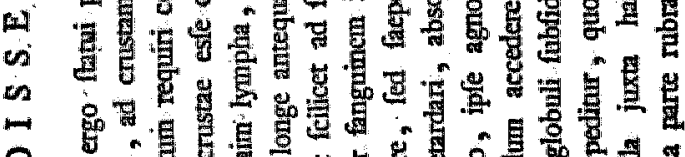
$\vec{A}$. 율

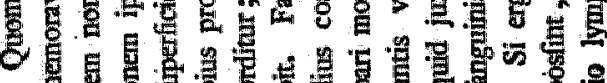

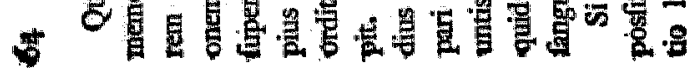

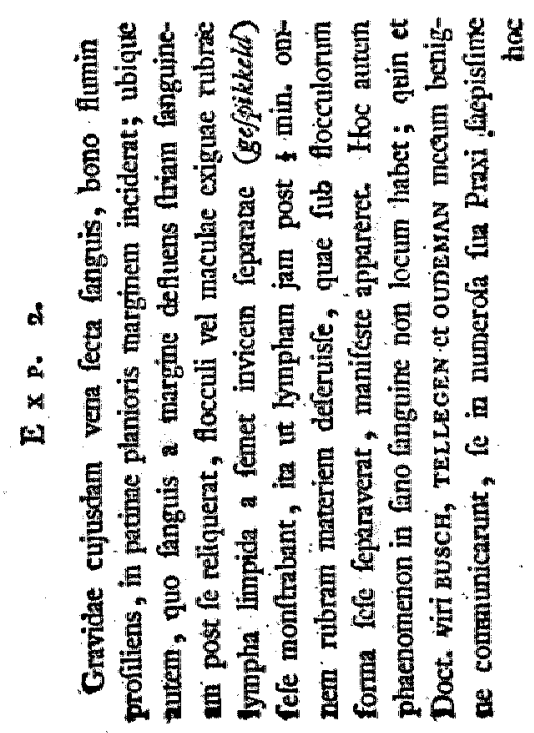

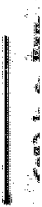




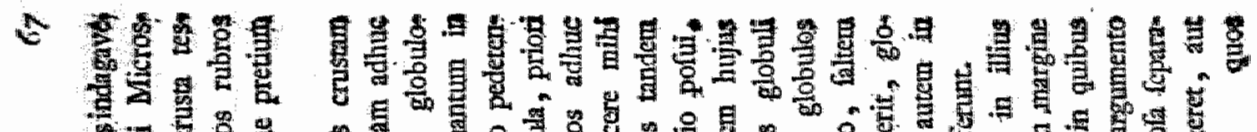

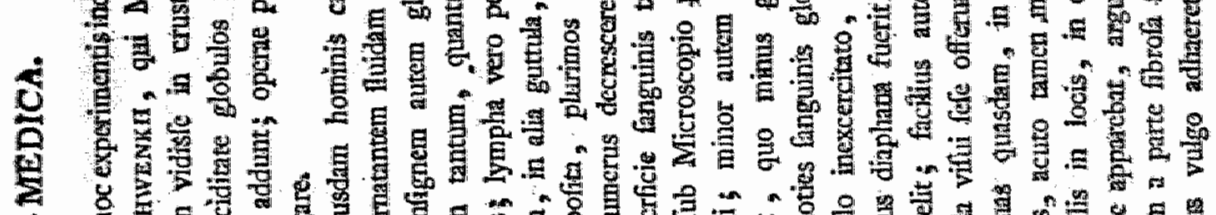

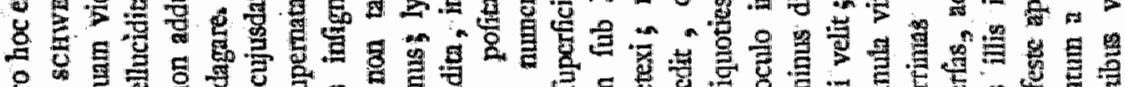

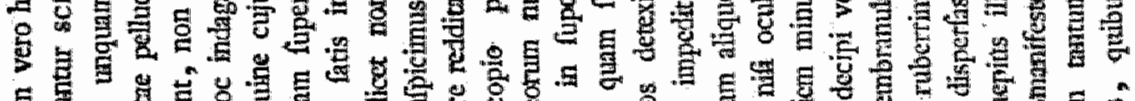

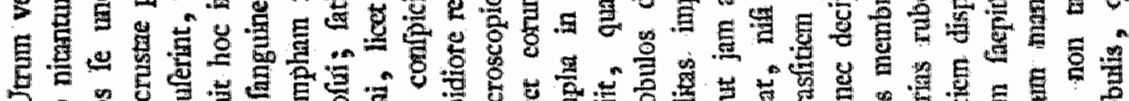

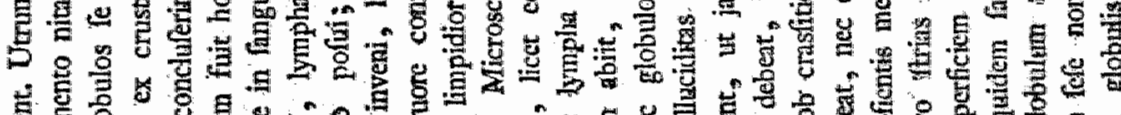

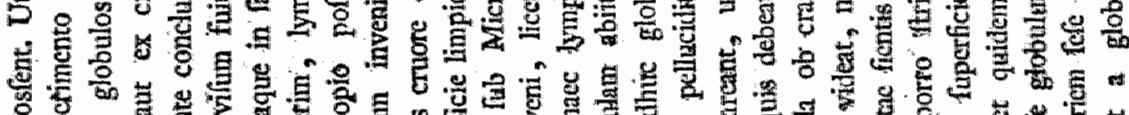

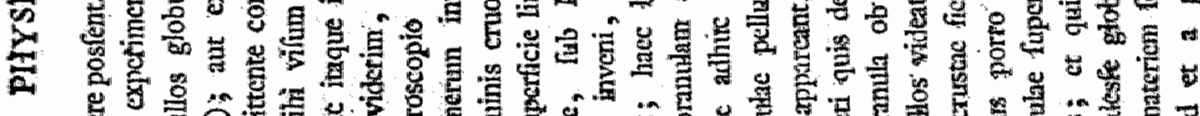

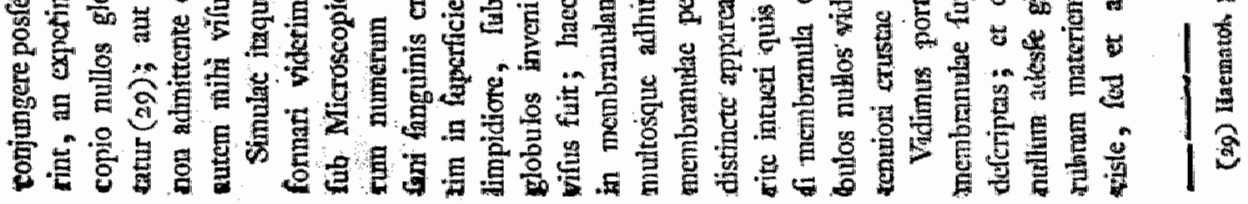

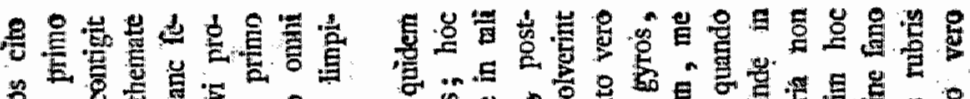

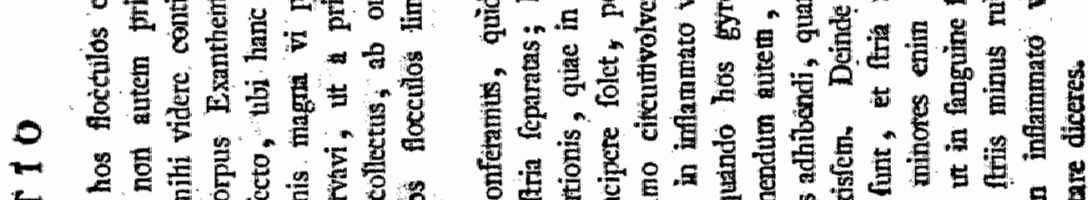

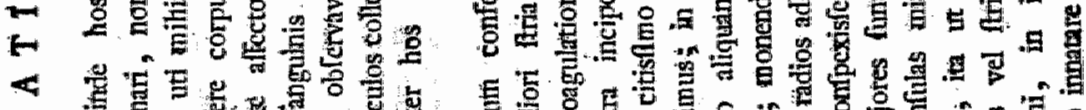

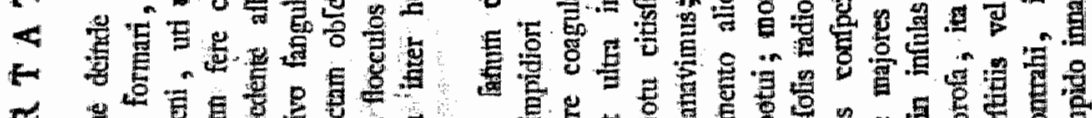

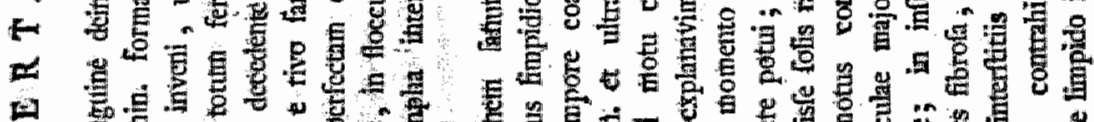

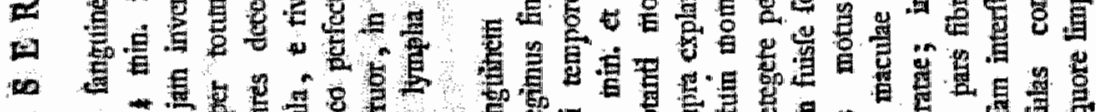

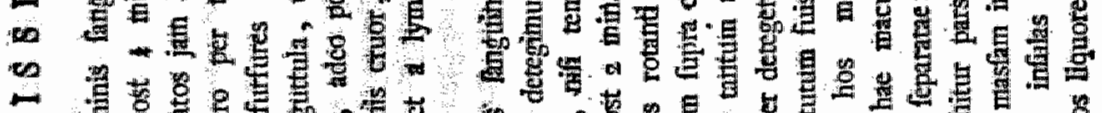
口

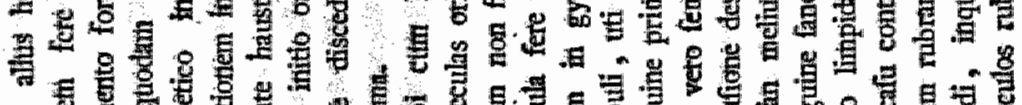

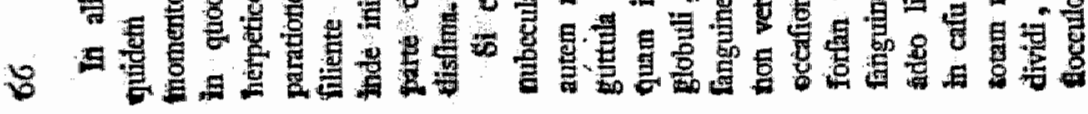

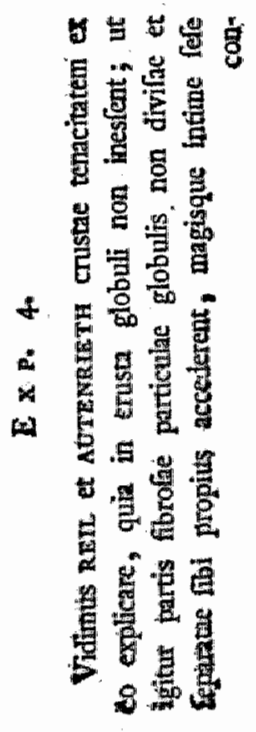




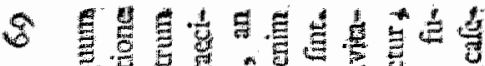

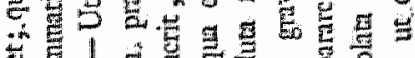

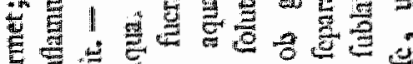

元

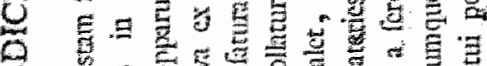

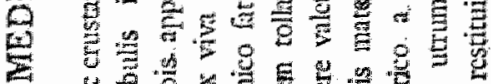

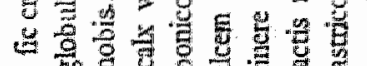

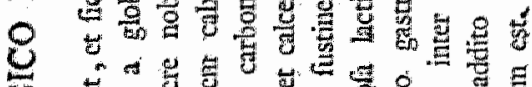

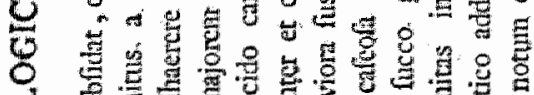
車

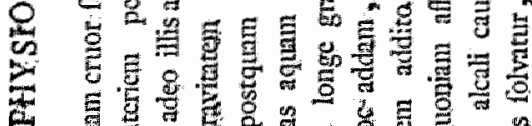

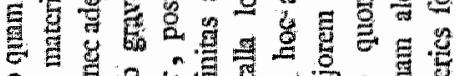
응

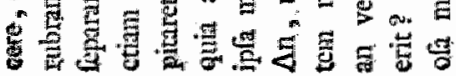

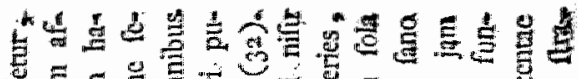

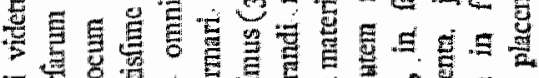

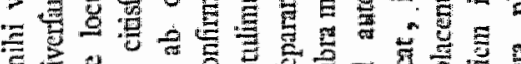

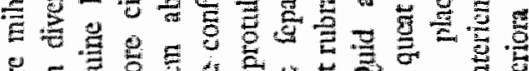

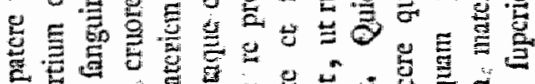

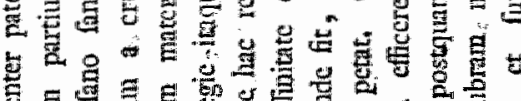

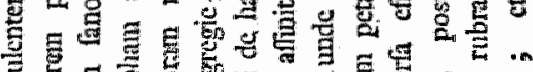

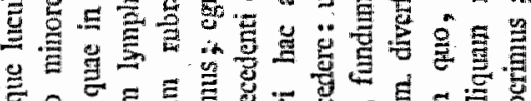

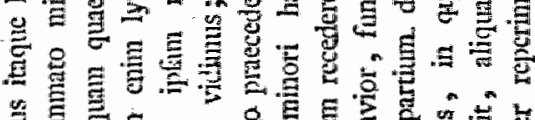

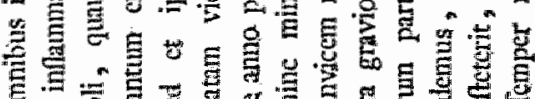

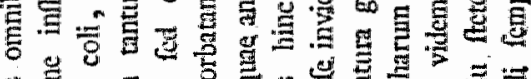

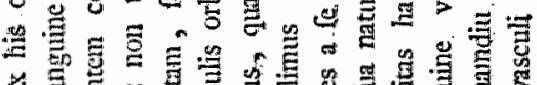

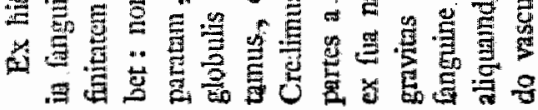

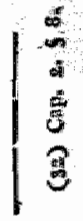

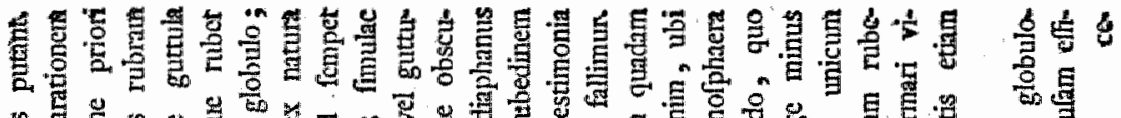

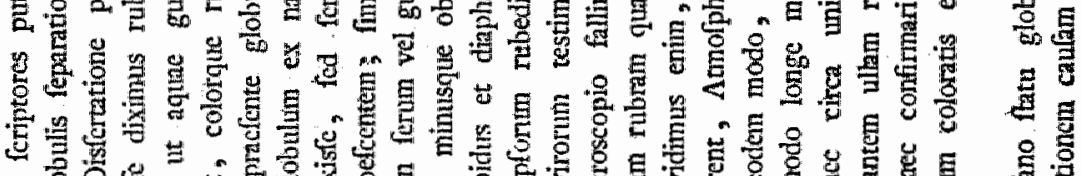

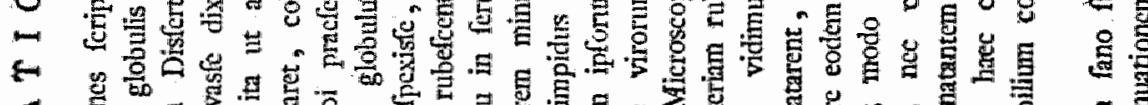
4

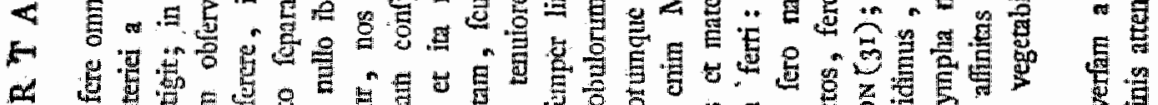

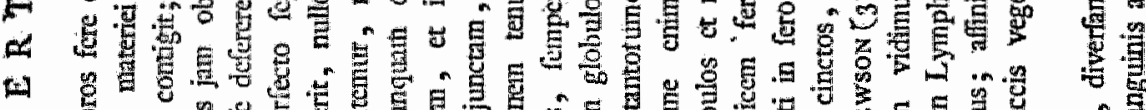

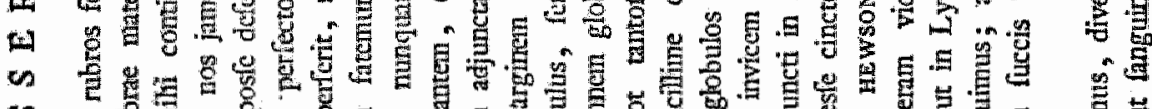

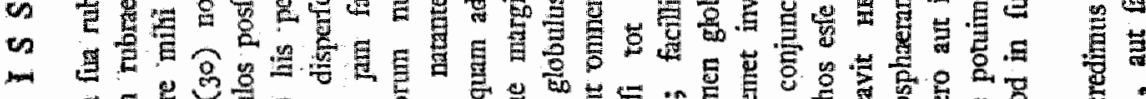

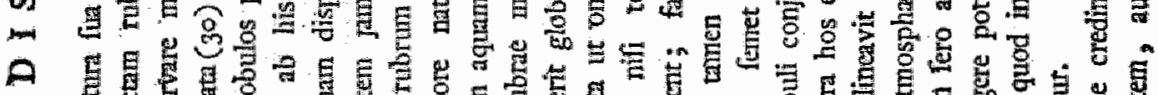

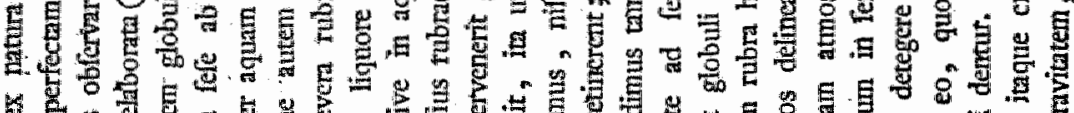

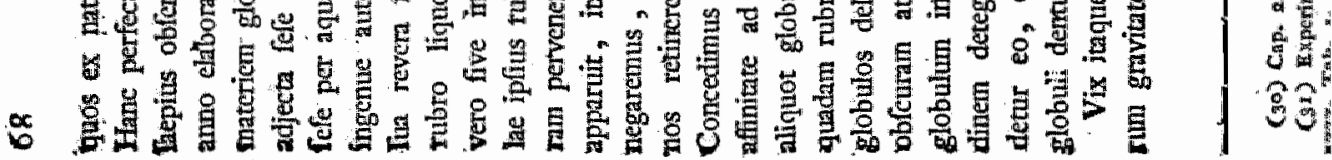


๙ 章 ક

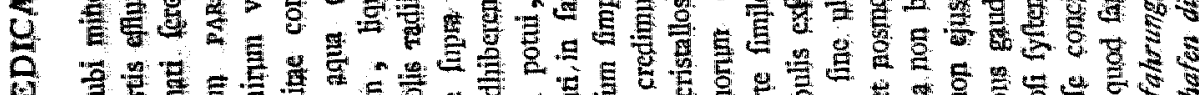

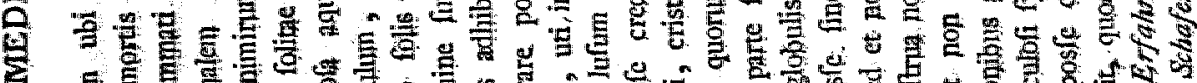

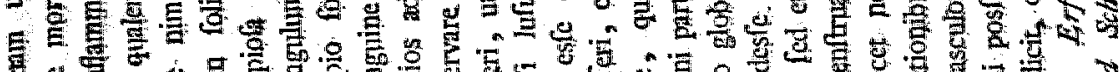

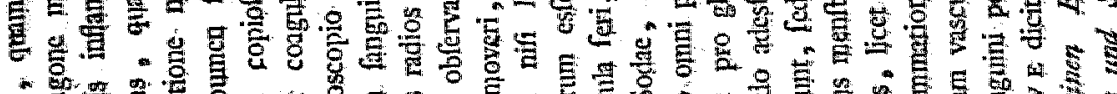

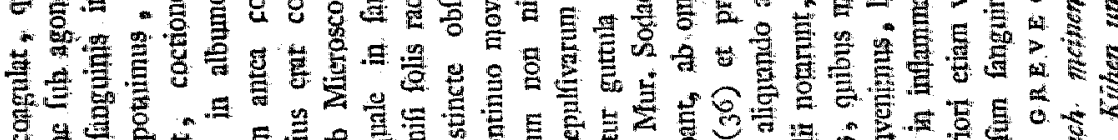

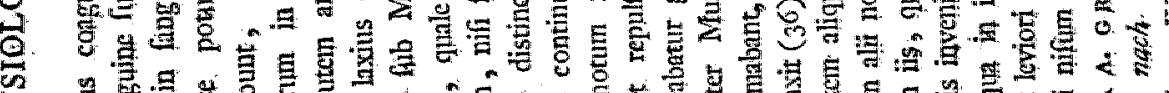

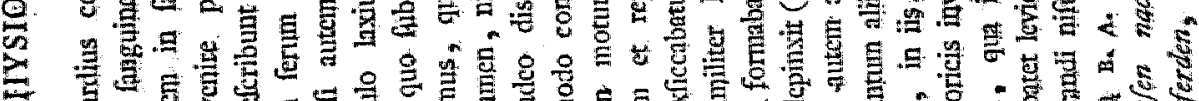

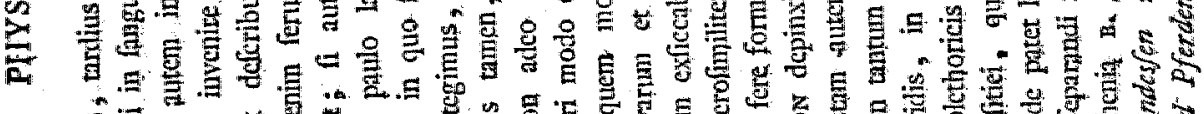

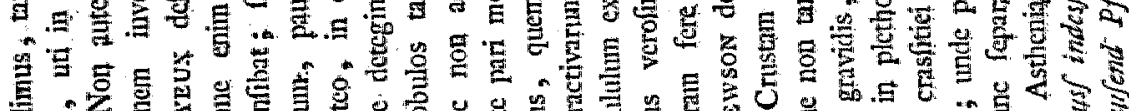

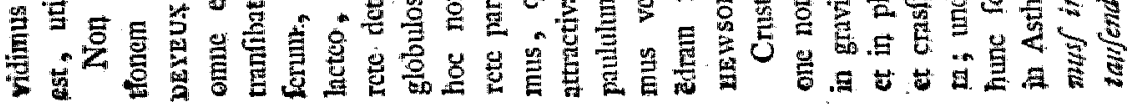

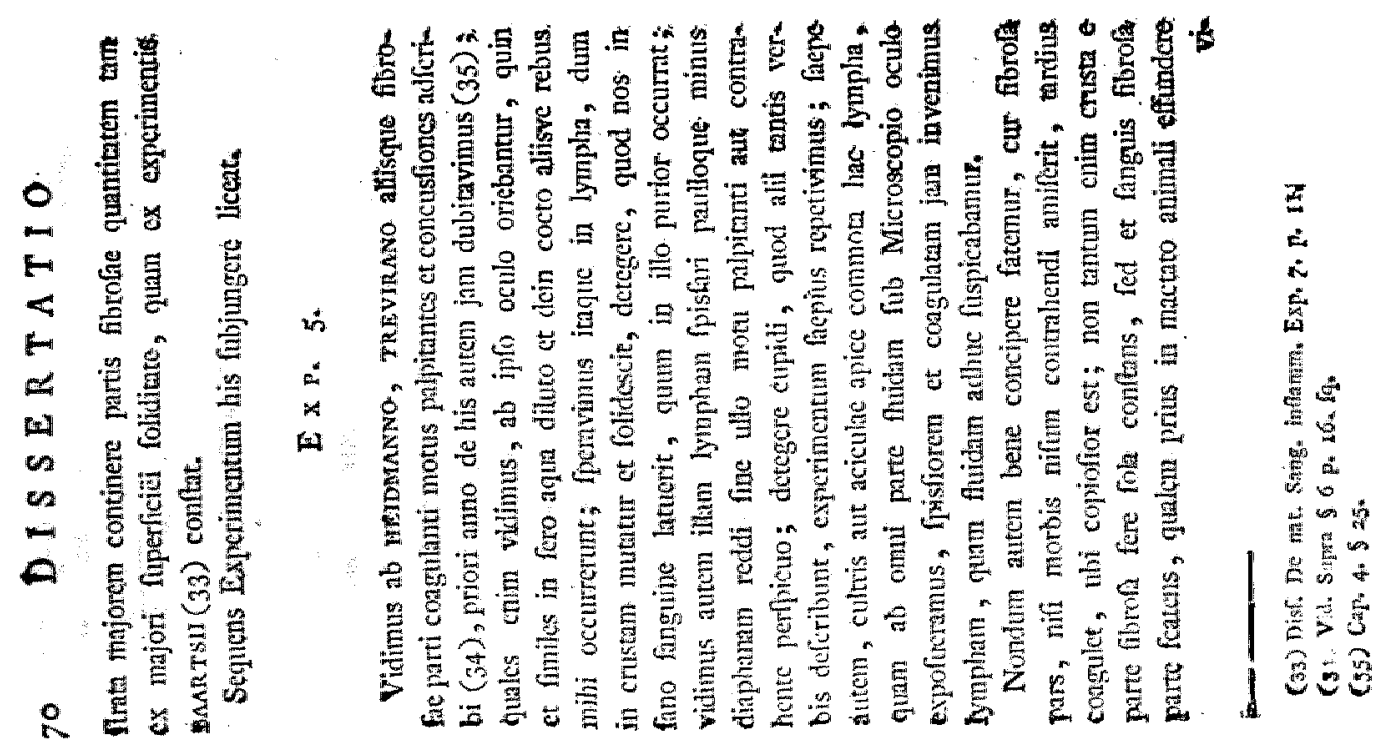




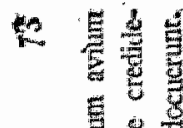

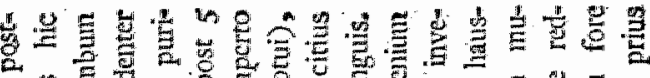

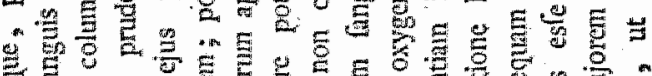
to

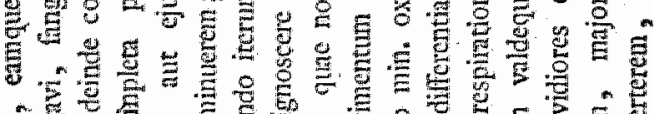

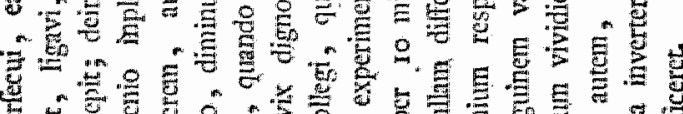

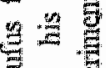

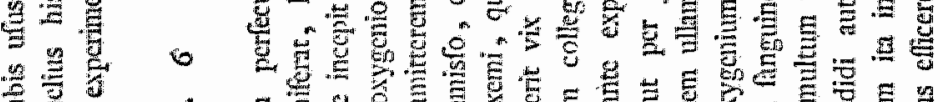
ㄹ.
娄 $\frac{1}{8}$
尊部

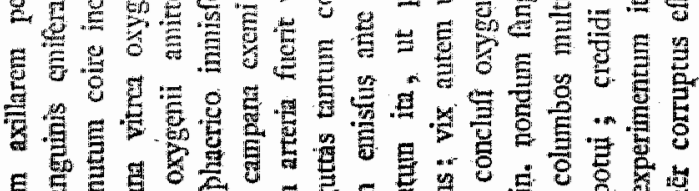

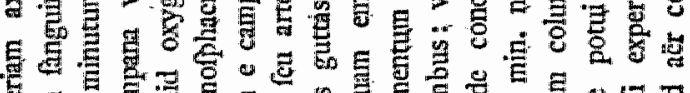

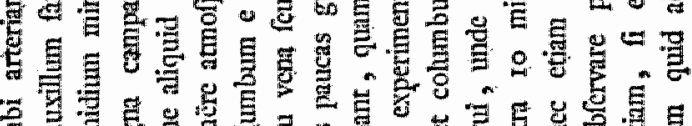

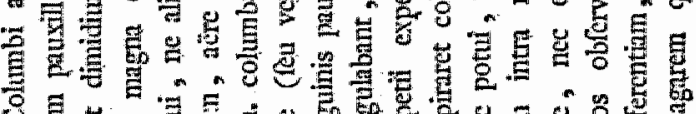

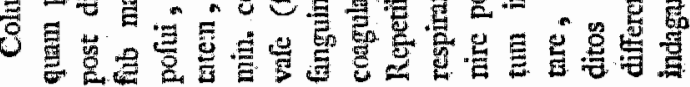

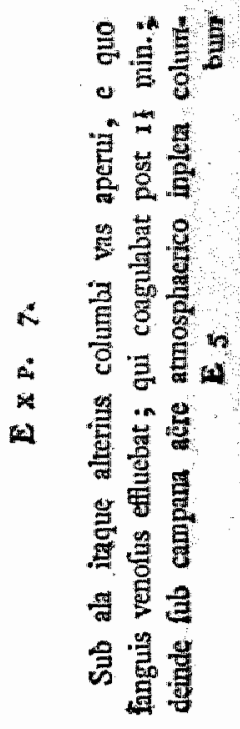

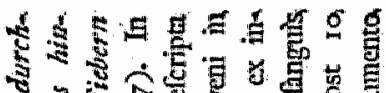

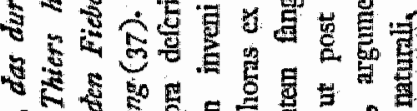

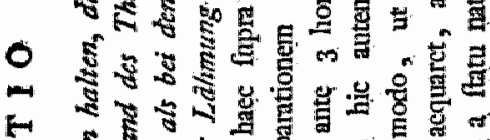

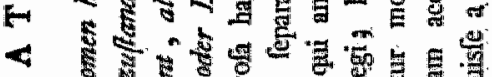

4 -

- क

*

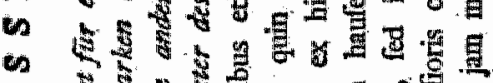

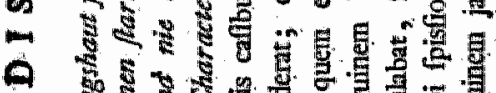

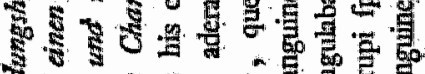

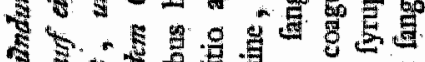
a

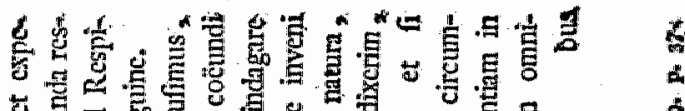

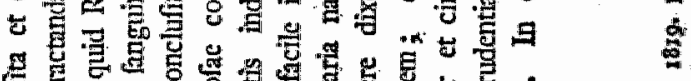

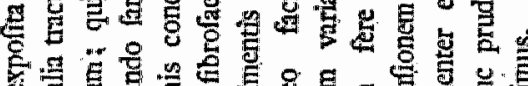

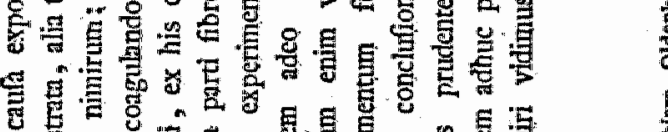

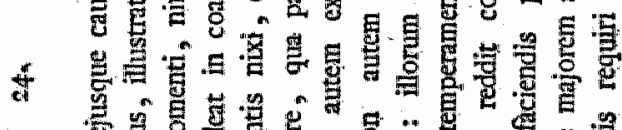

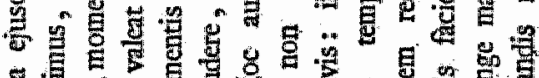

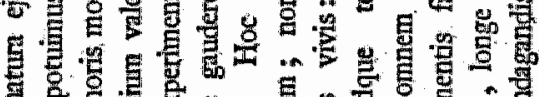

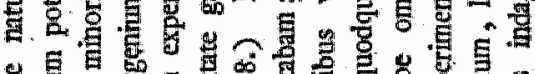

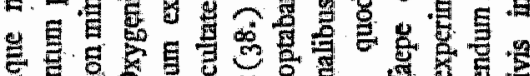

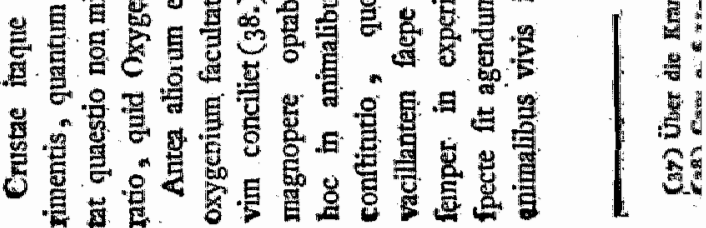



人

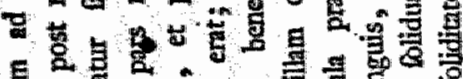

\& 5 .

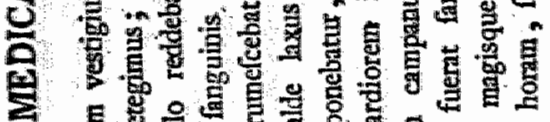
응 연

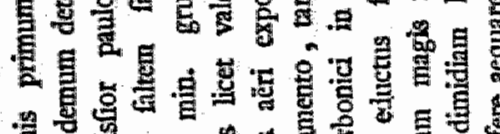

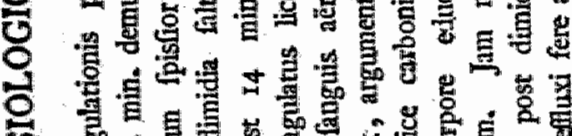

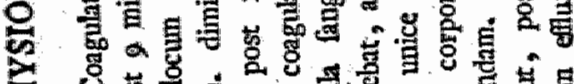

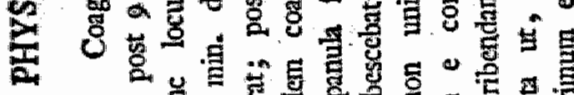

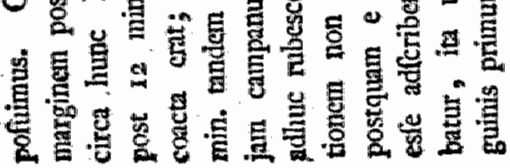

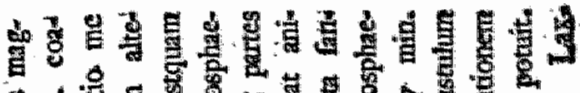

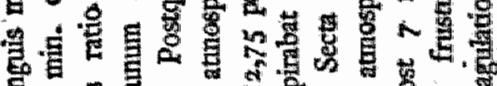
至。重

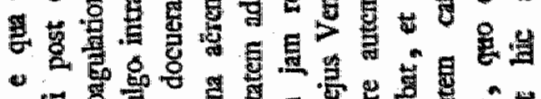
舟

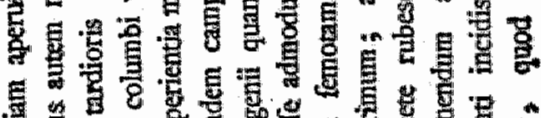

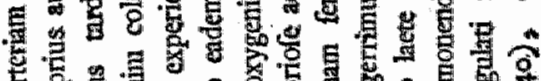

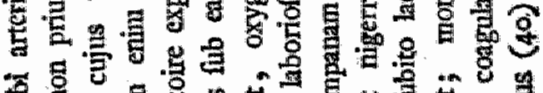

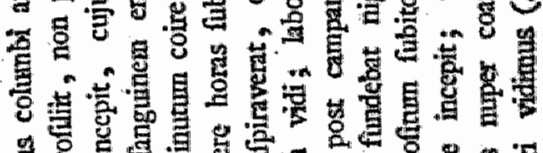

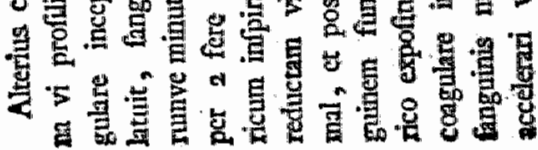

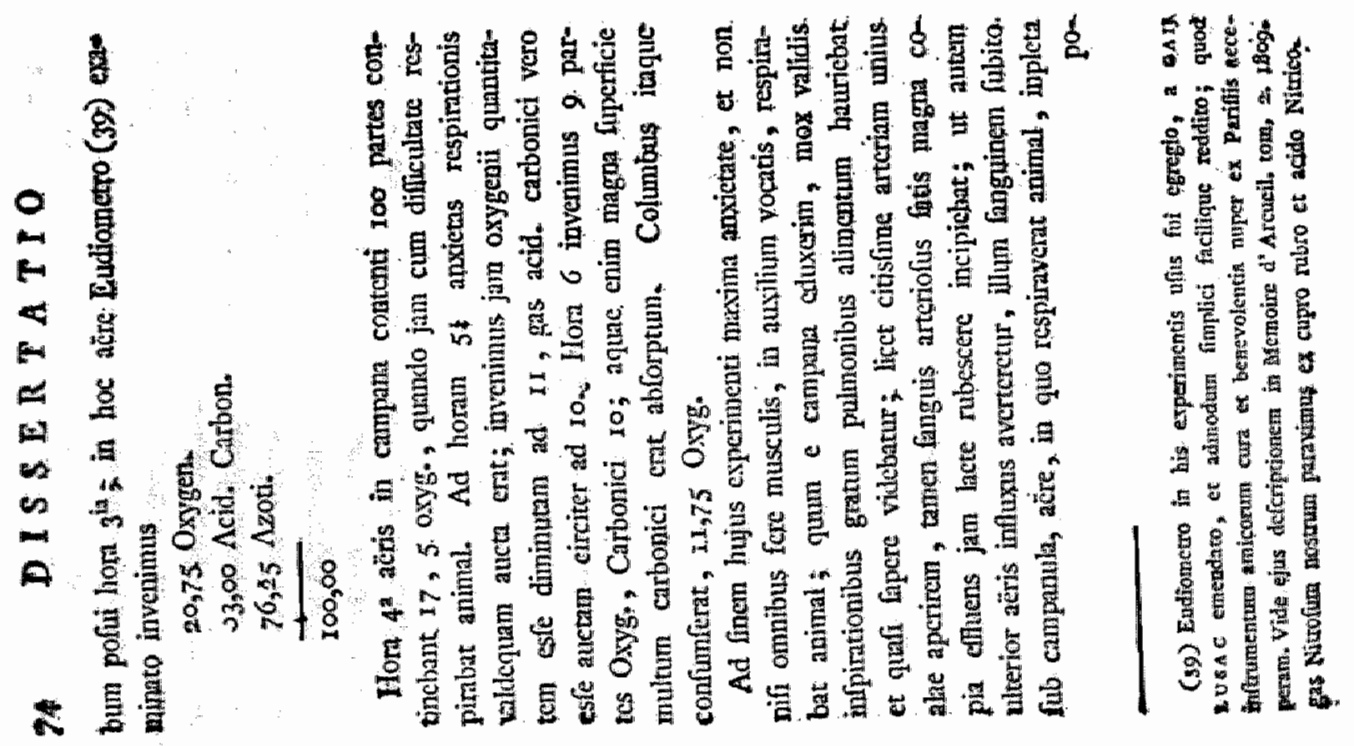




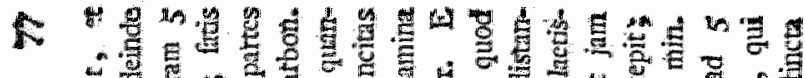

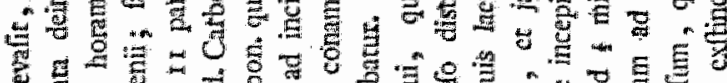
을

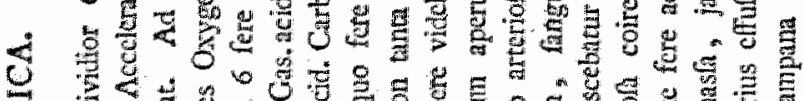

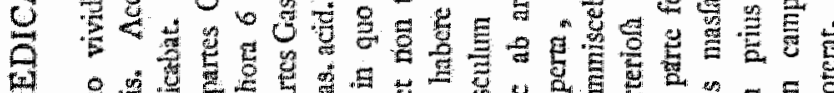

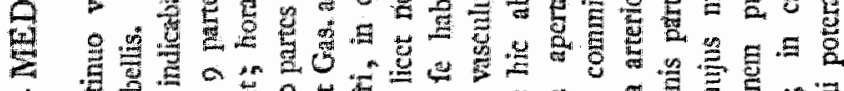
○

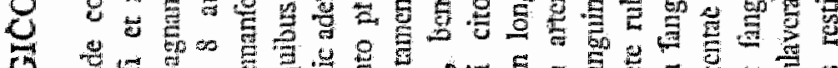

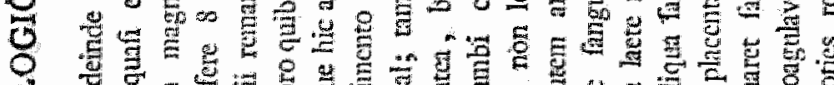

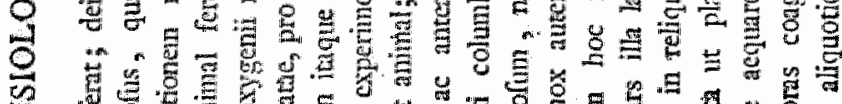

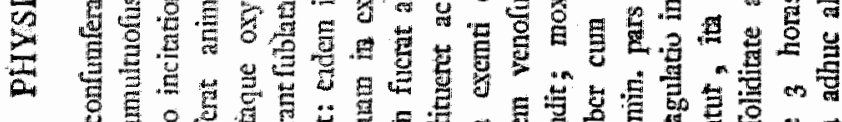

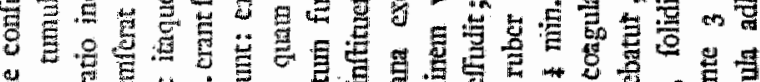

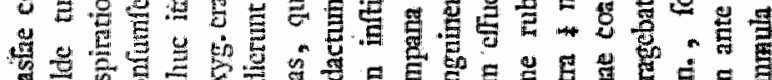

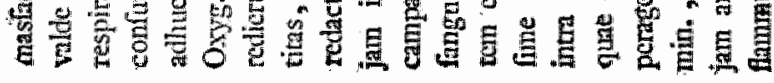

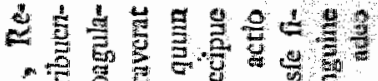
들

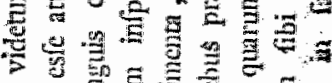

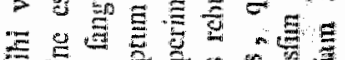

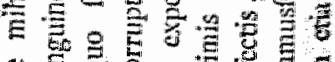

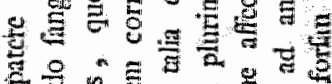

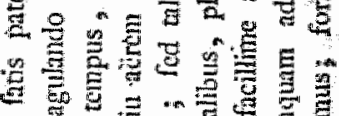

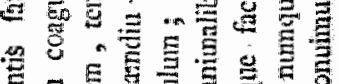

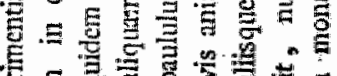

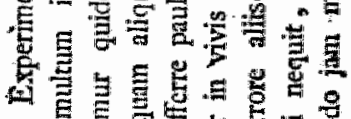
글

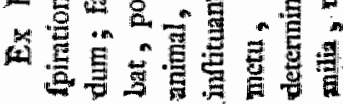

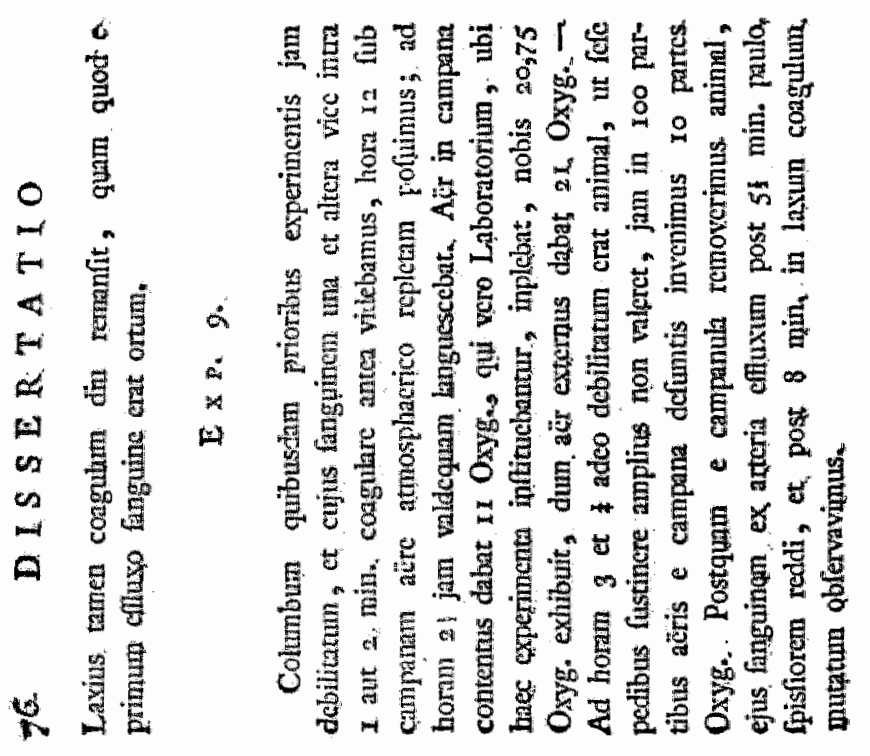

言

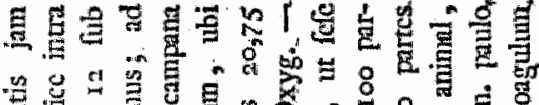

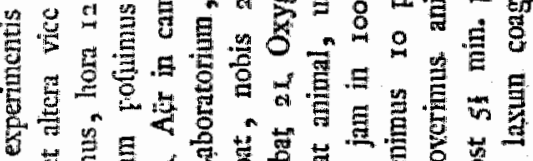

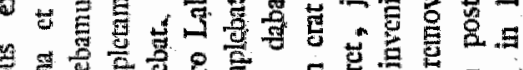

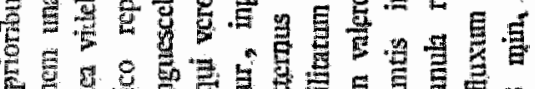




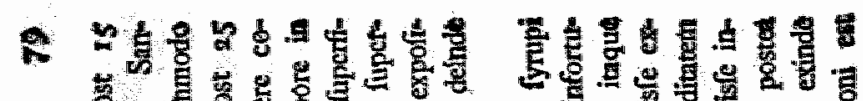

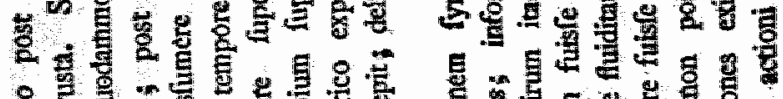

仓

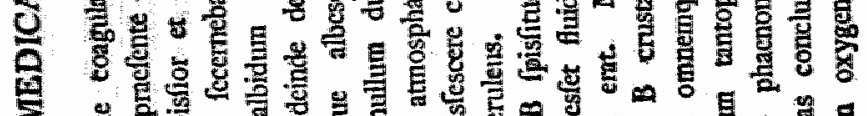

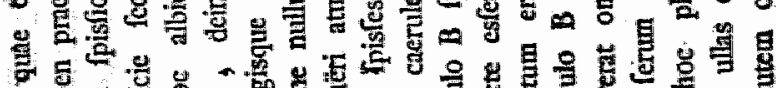
o

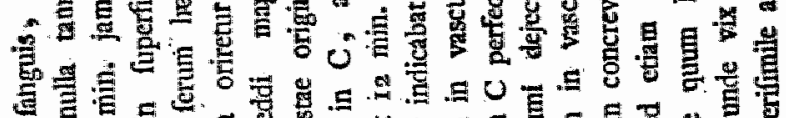

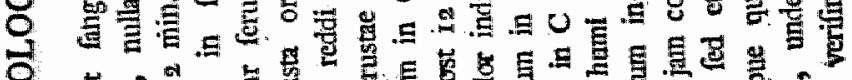

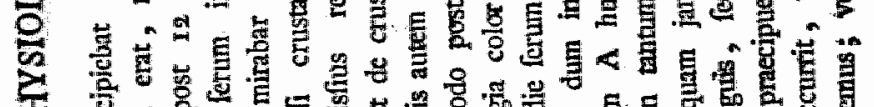

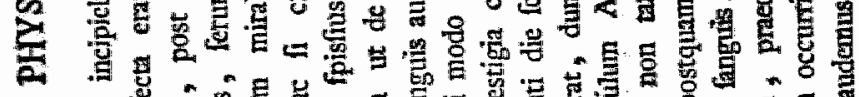

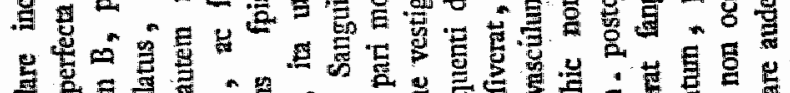

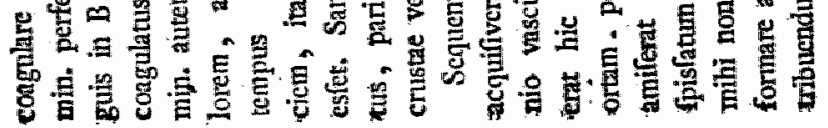

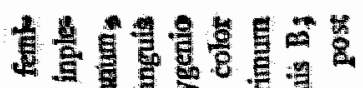

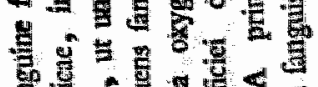

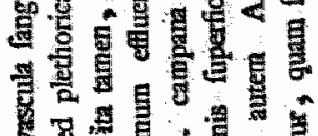
贻, - 谓直最

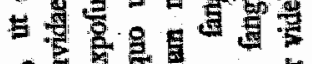
×

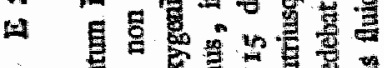

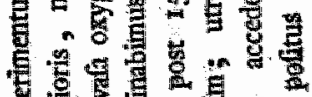
C.

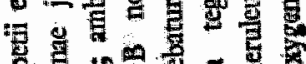

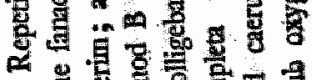

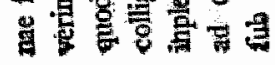

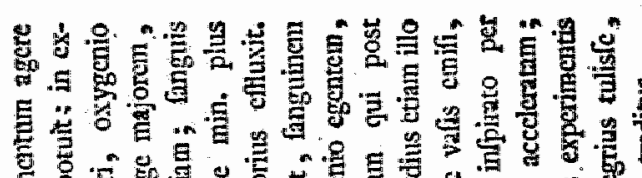

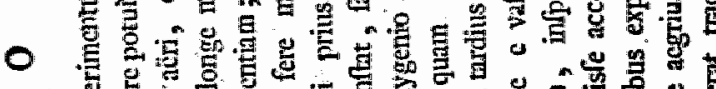

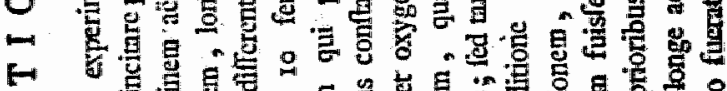

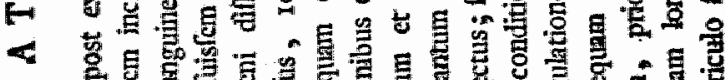

— 2

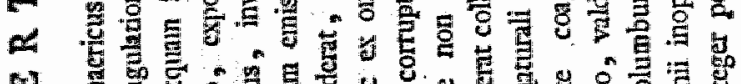

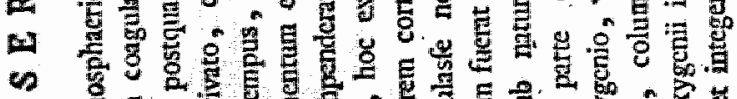

is

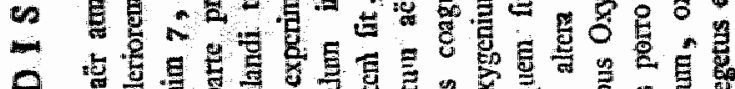

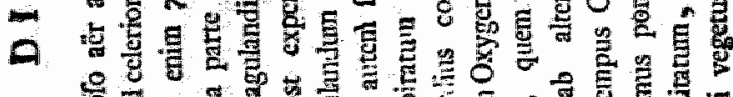

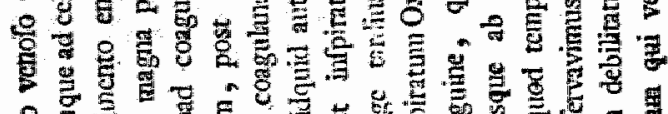

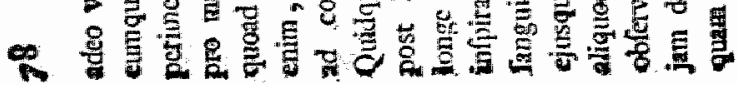

总总苞

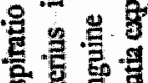

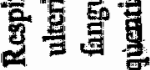

可

晋基

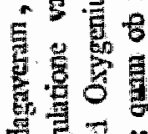

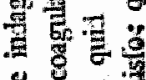

崖定

牙:

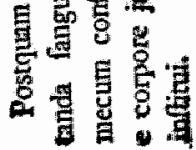

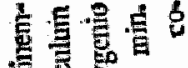

暨罗放:

落

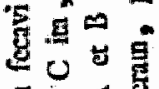

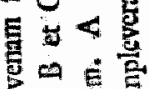

我密

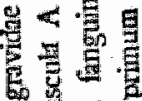

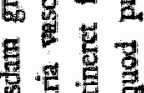

家.

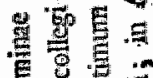

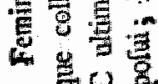


क

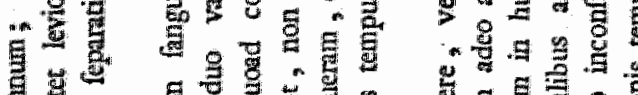

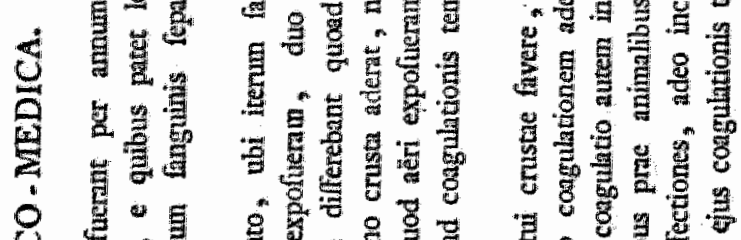

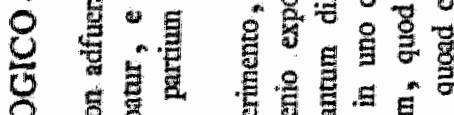

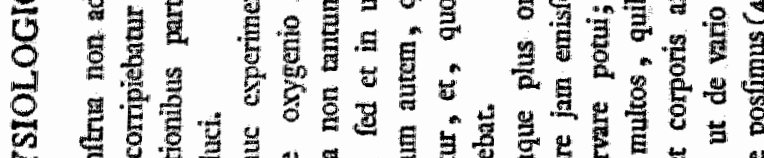

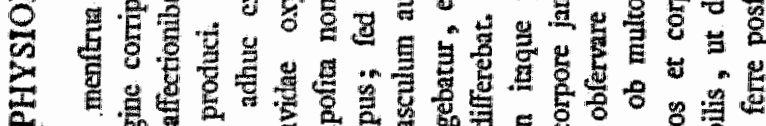

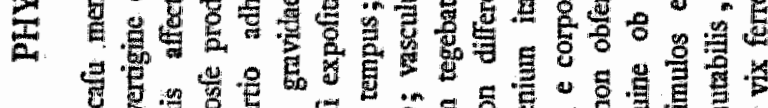
골 5

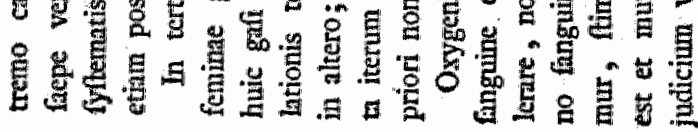

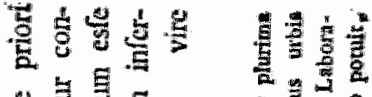

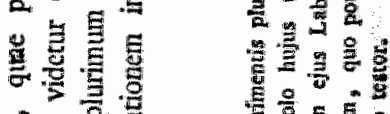

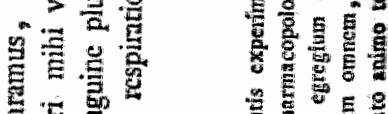

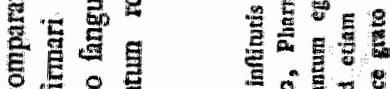

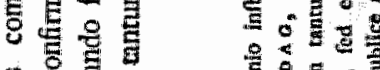

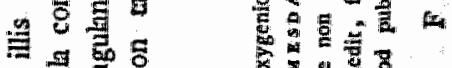

垫

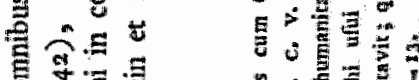

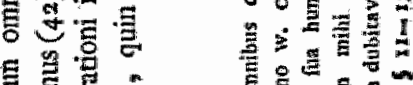

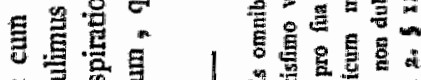

若

क央递总

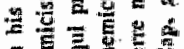

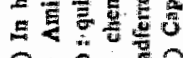

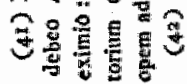

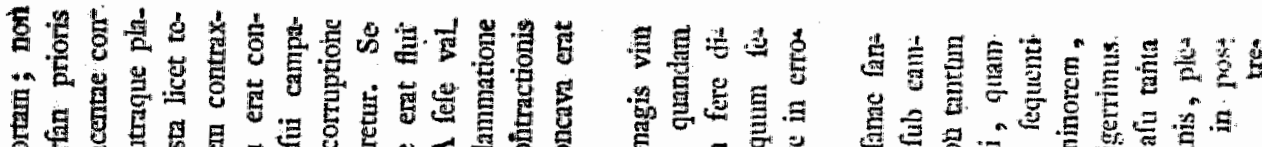

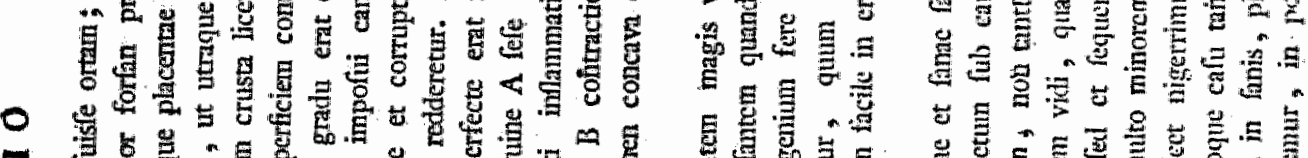

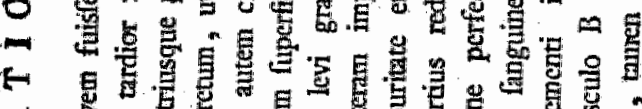

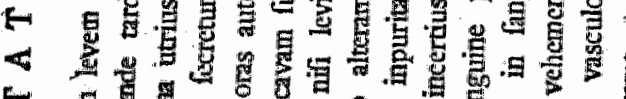

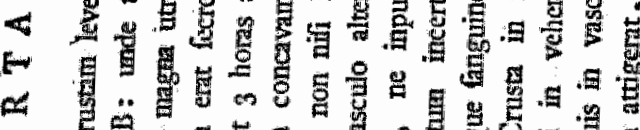

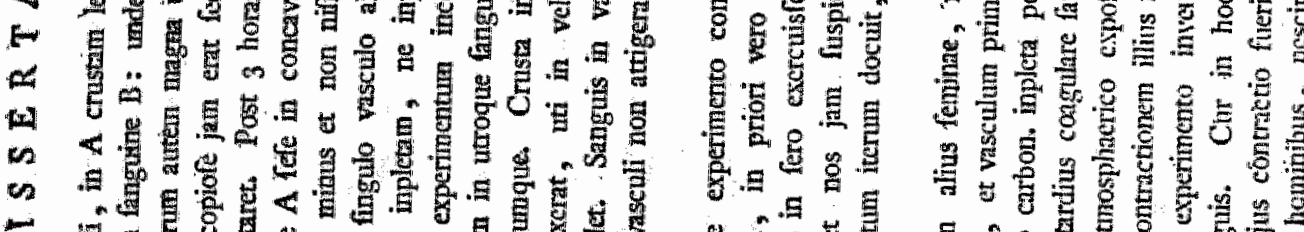

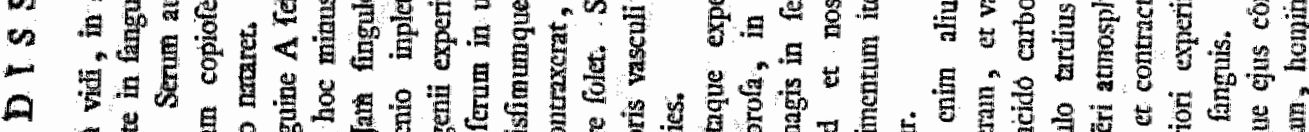

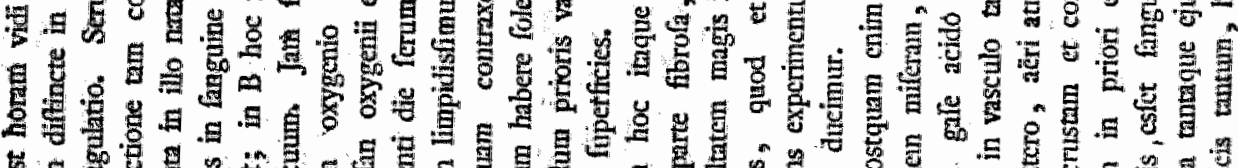
๖ 


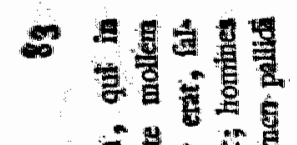

of

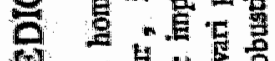

鱼 on

o d

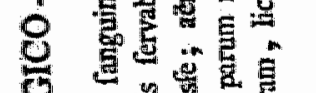

일

을

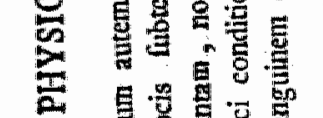

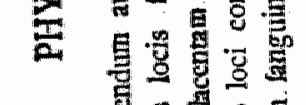

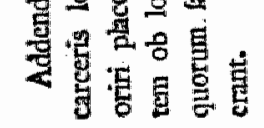

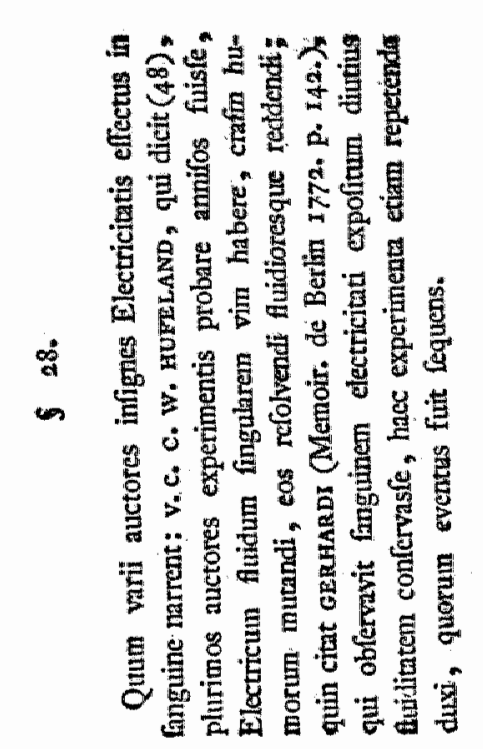

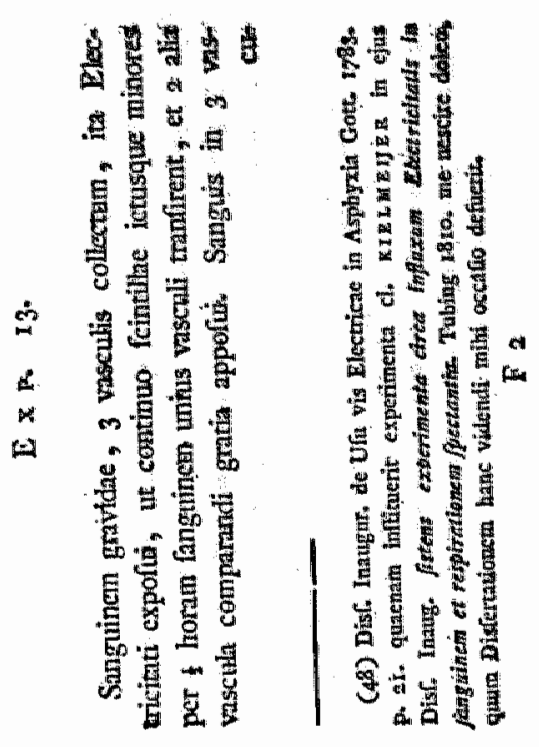

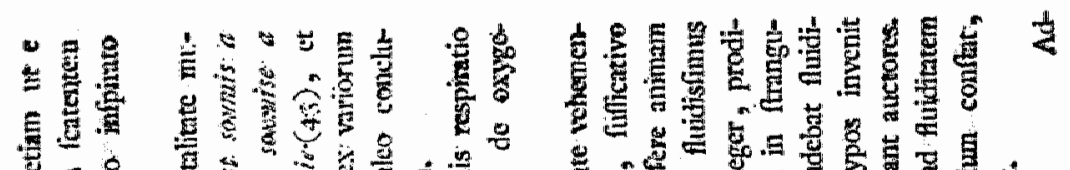

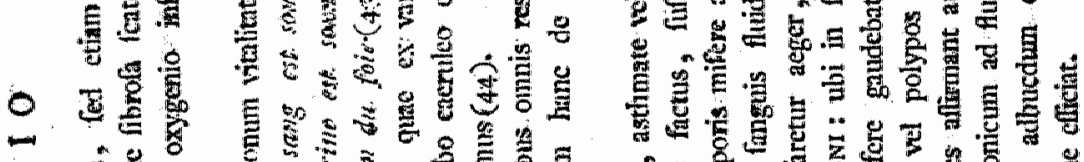
F 至 -

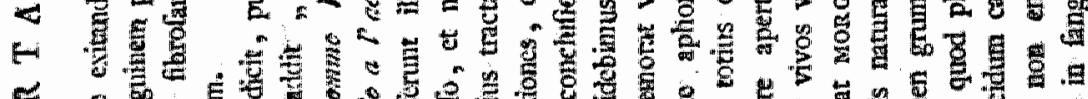

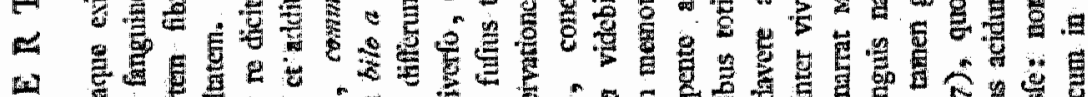

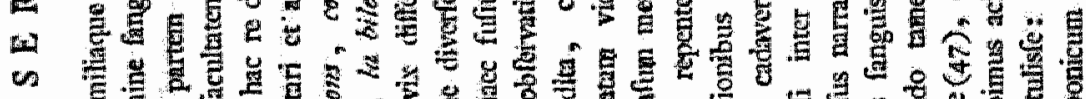
so

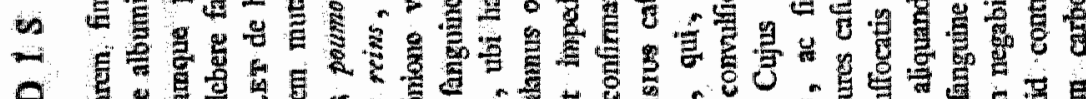
a $\frac{1}{3}$

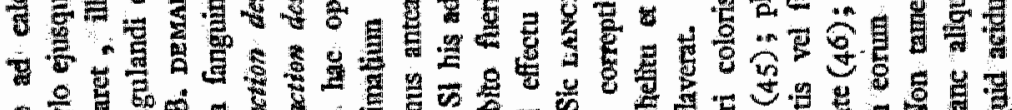

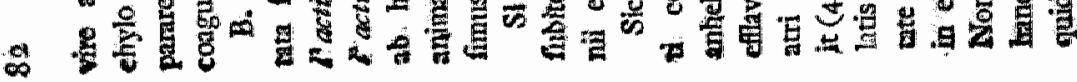

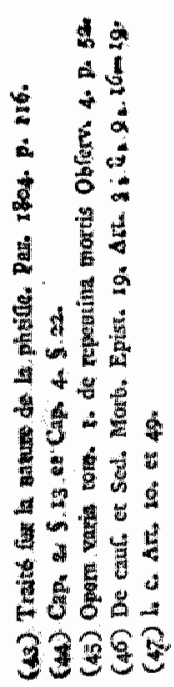




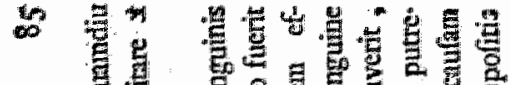

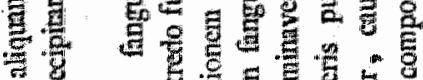

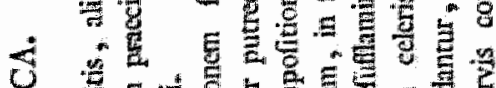

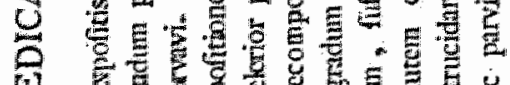

总

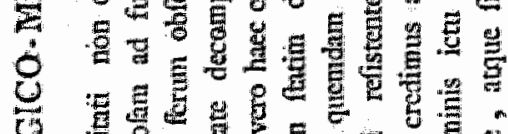
万人

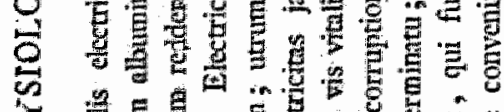

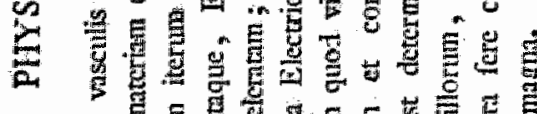

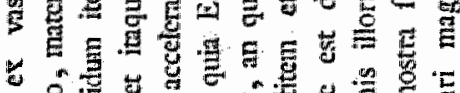

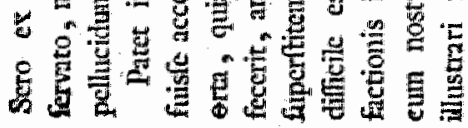

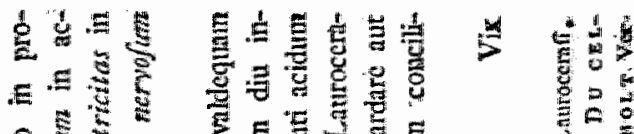

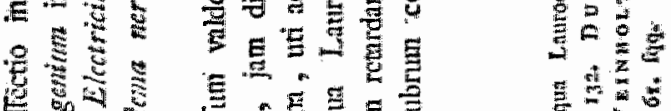

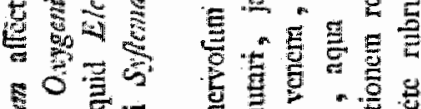

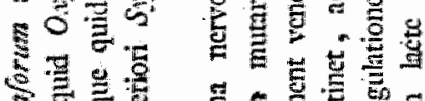

今势

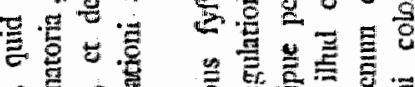

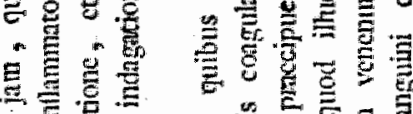

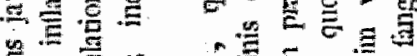

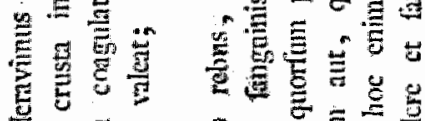

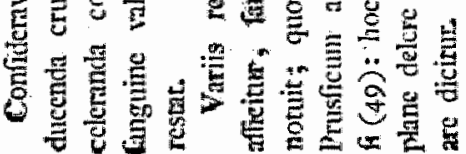

$5=\frac{2}{5}$

更

紊安安

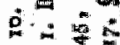

i

$\dot{0} \dot{s}$

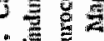

言要焉

究点

要政

这音

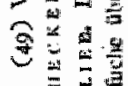

喜我

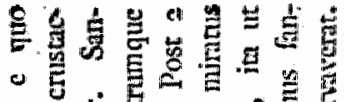

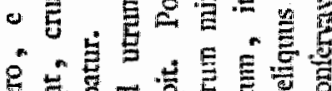

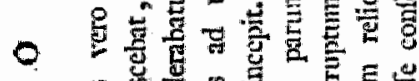

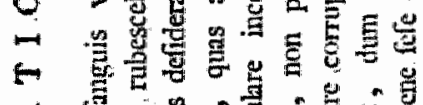

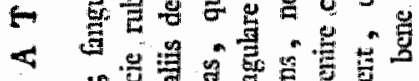

\&

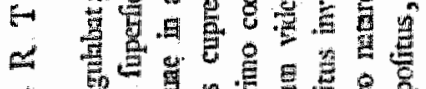

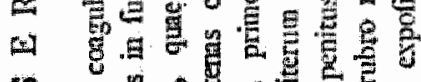

in

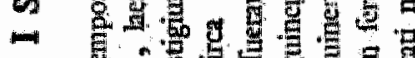

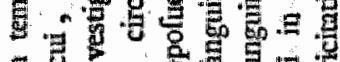

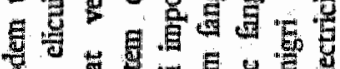
\&

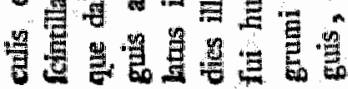

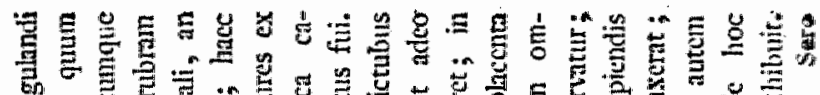

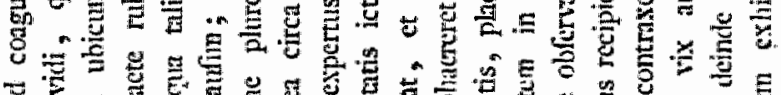

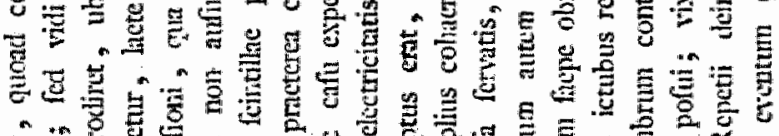

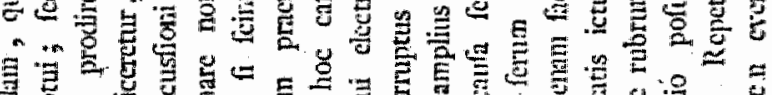

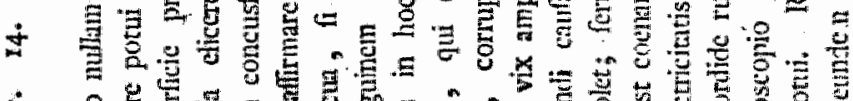

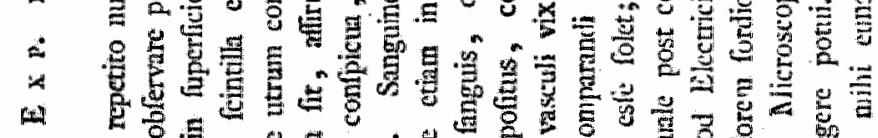

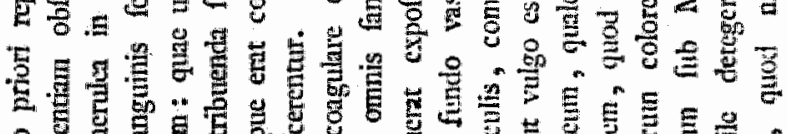

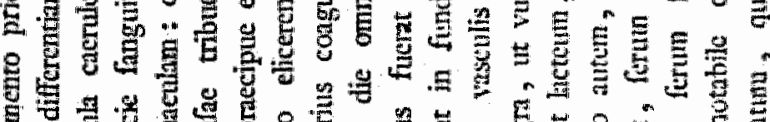

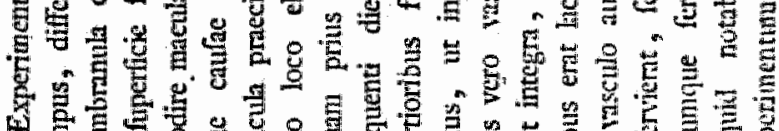

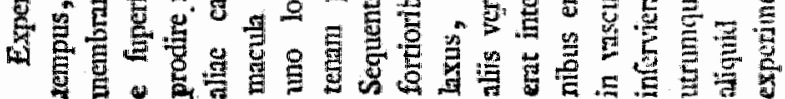




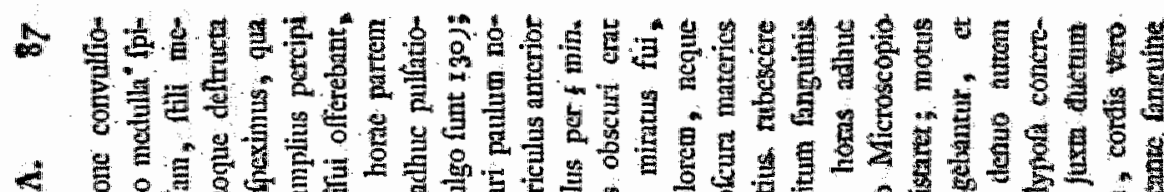

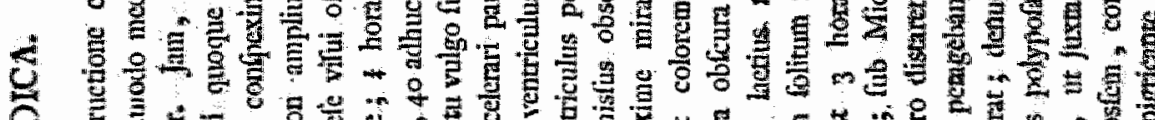

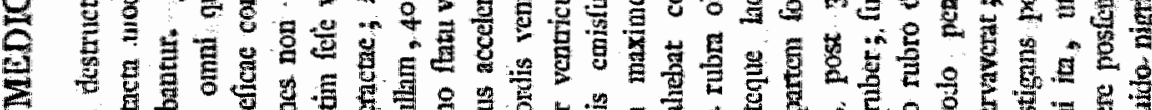

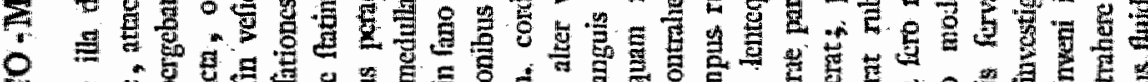

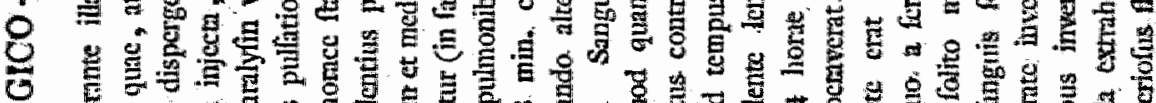

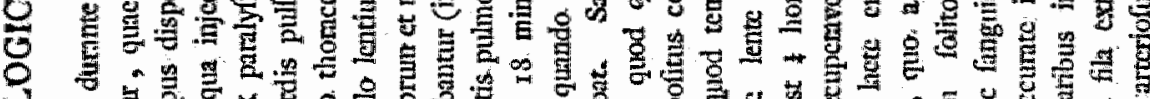

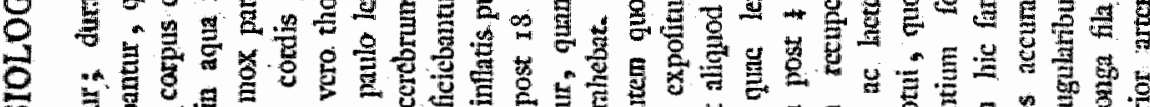

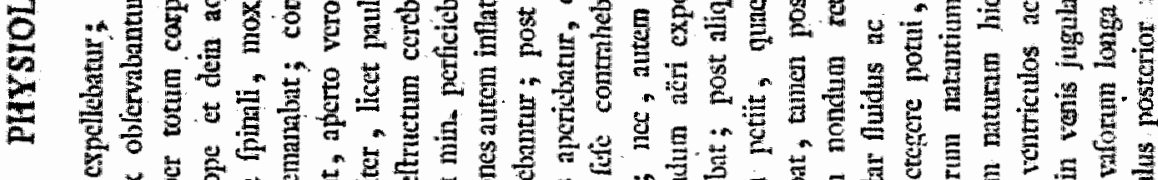

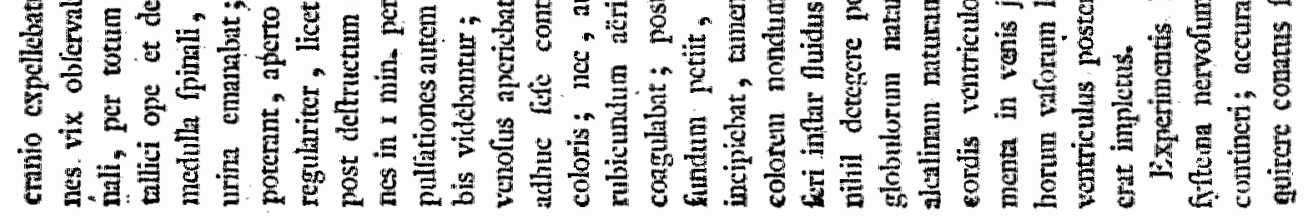

鼻高离

$\sum_{0}$

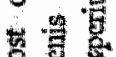

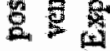

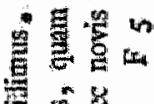

s.

管望量

婙

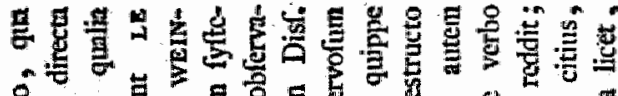

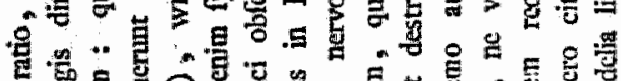

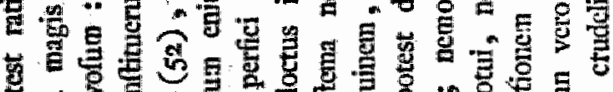

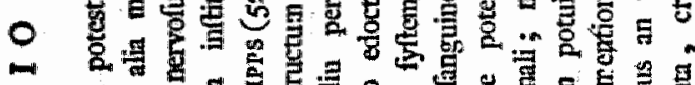

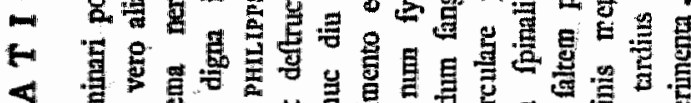

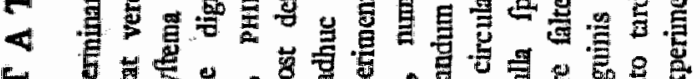

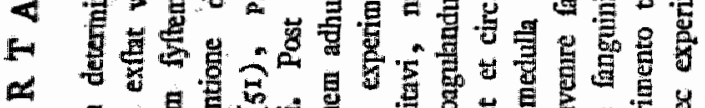

4

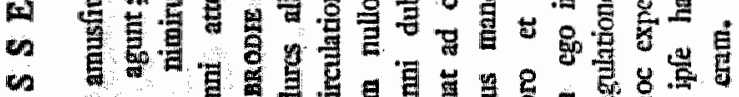

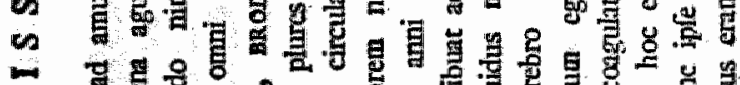

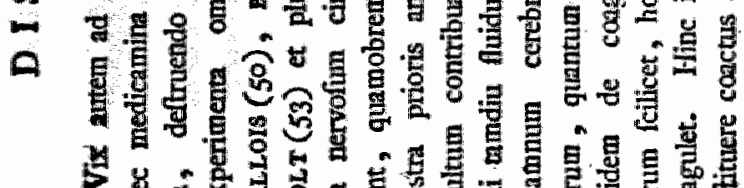

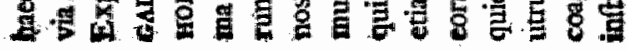

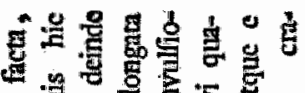

렬

홍

.

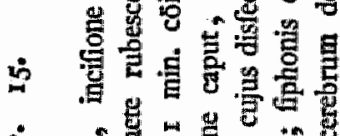

- I

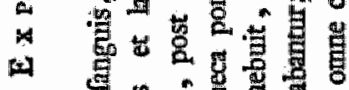

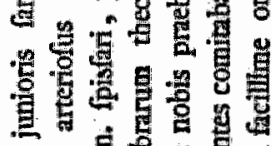

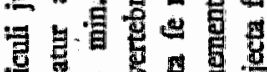

鄫总

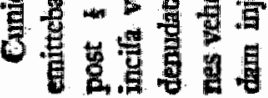

區

\$

తi.

总总

若

$\div \div$

里

4.

4.

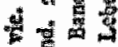

‥ ㄴ.

娄

\&

6

㱐要

gas 


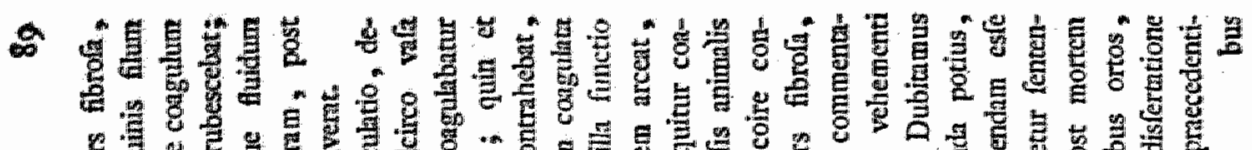

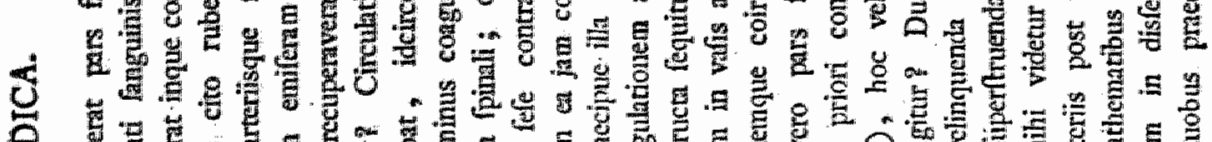

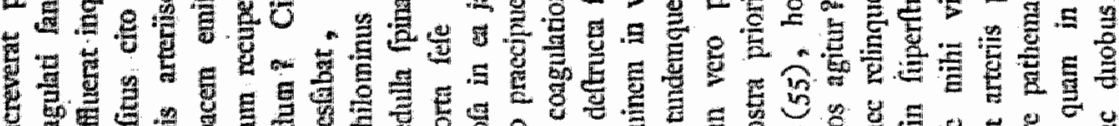

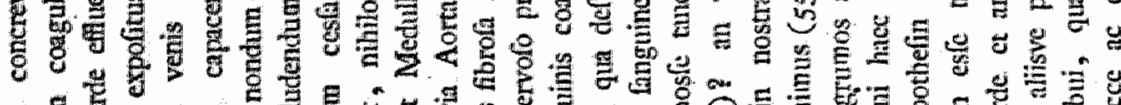

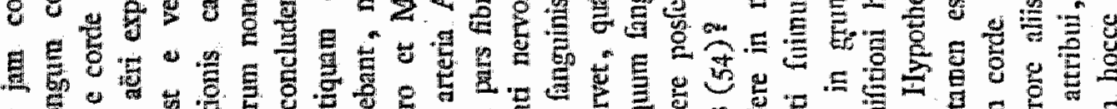

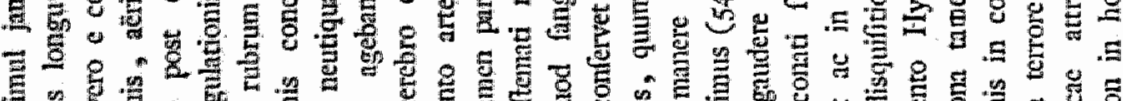

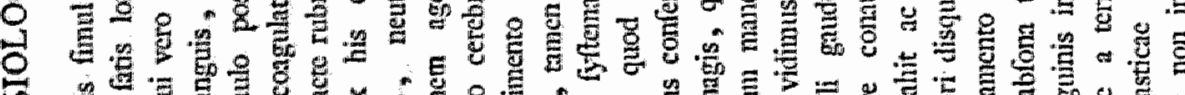

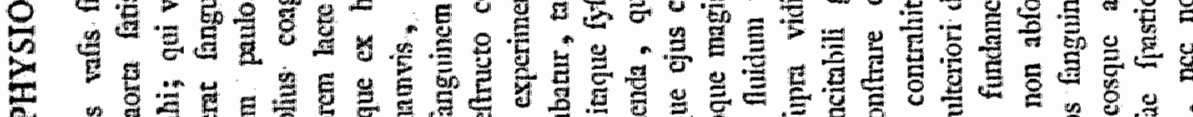

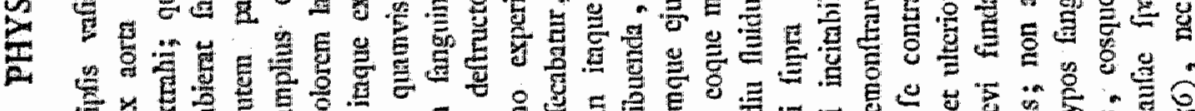

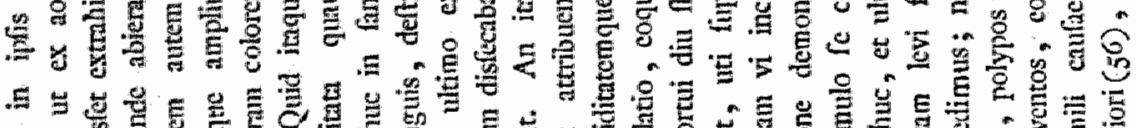

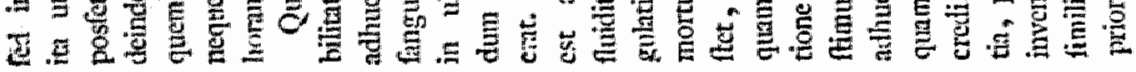

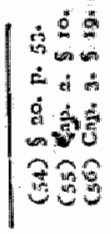

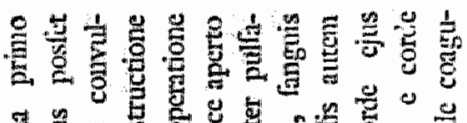

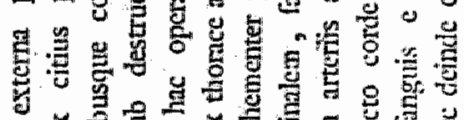

$\therefore$ b

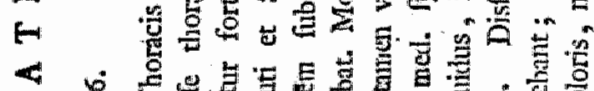

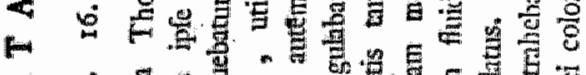

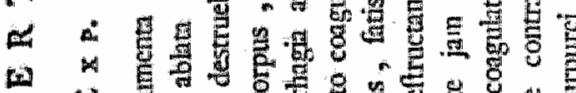

क w

o E E

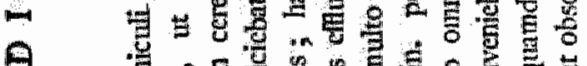

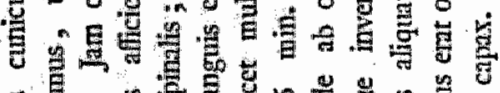

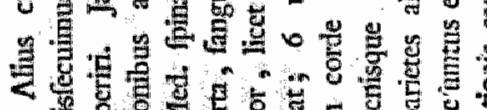

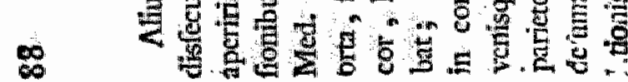

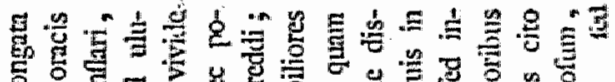

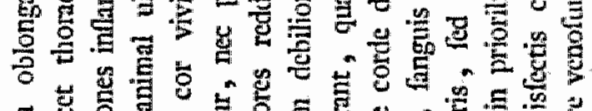

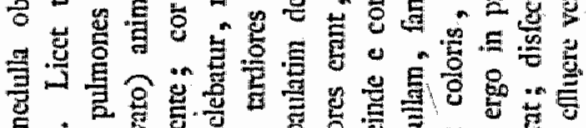
告.

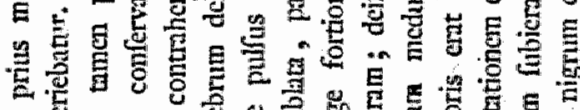

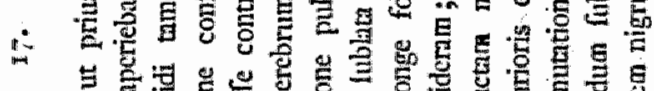

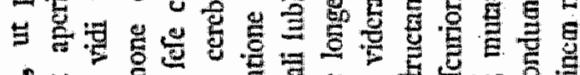

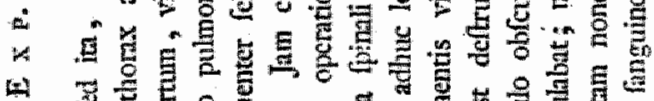

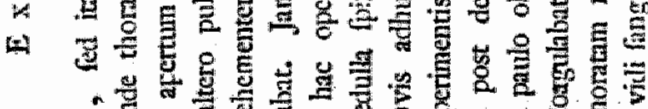

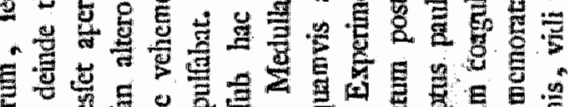

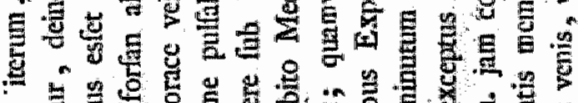

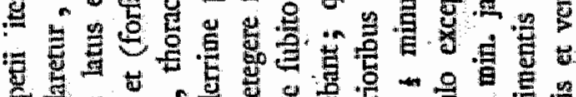

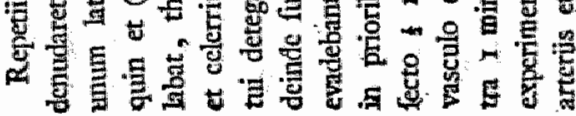




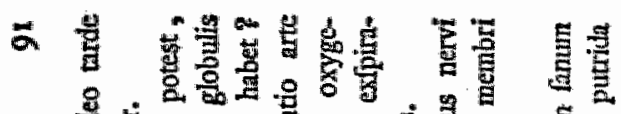

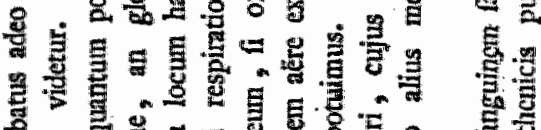

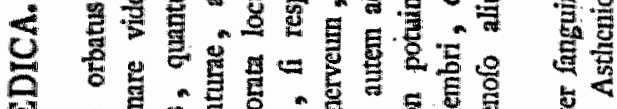

告

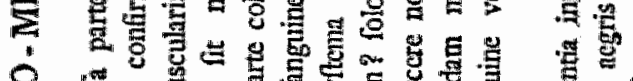

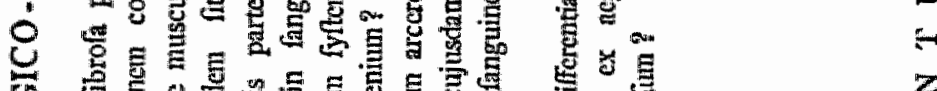

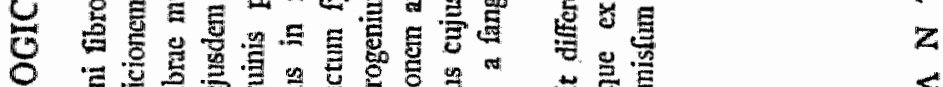

Q

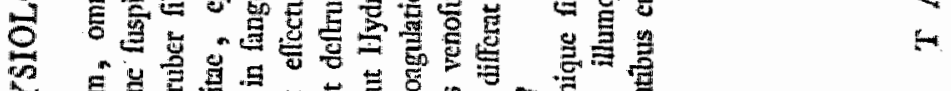

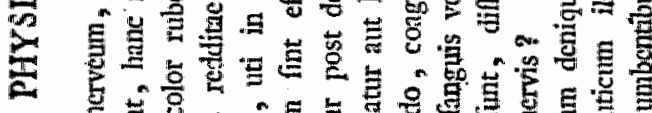

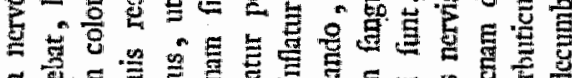

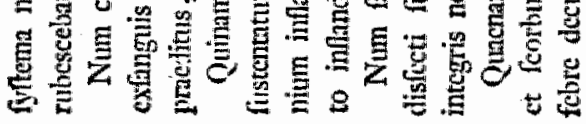

5

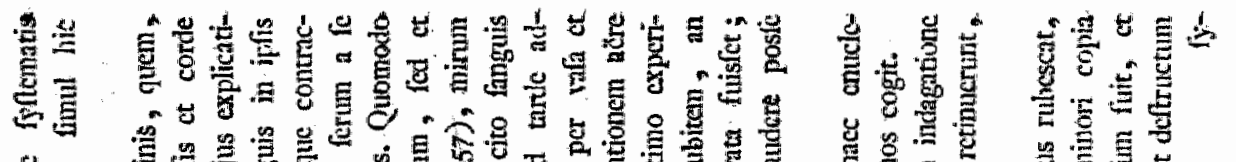

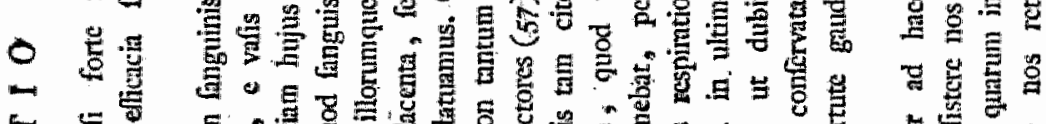

$\leftarrow$ 돌

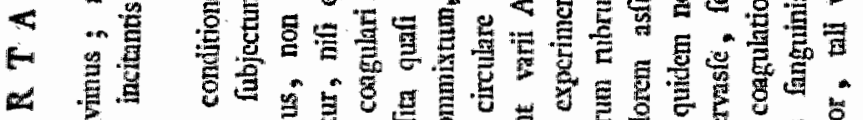

年

os

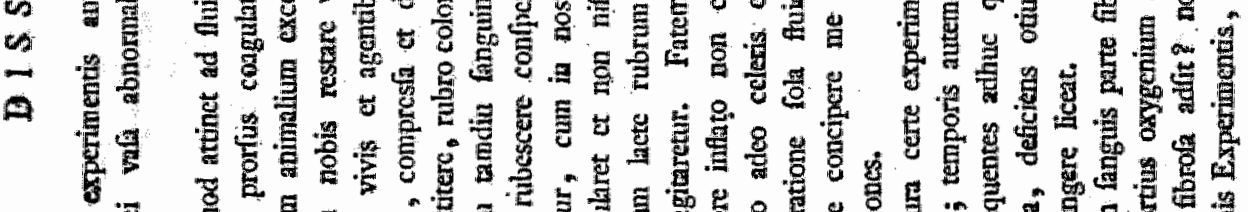

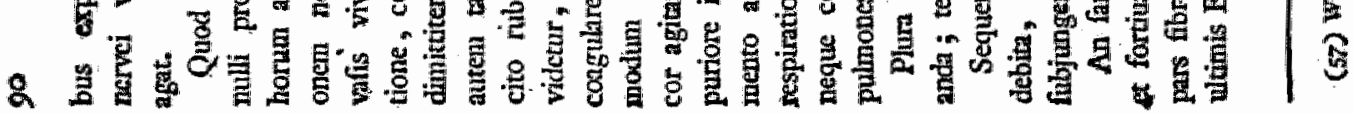


" 


\title{
LUST VAN PUBLICATIES DOOR
}

\author{
C.A. PEKELHARING
}

$1874-1922$

Over ureumbepaling in bloed en weefsels, Dissertatie, Leiden.

\section{5}

Sur le dosage de l'urée, Arch. néerland. des sciences exates et naturelles 10 , 56.

Ueber die Harnstoffbestimmung, Arch. ges. Physiol. (Pflüger's) 11, 602.

1880

Bijdrage tot de kennis van het pepton, Ned. Tijdschr. Geneesk. 16 ${ }^{1}, 65$. Beitrag zur Kenntnis des Peptons, Arch. ges. Physiol. (Pflüger's) 22, 185.

1881

Weiteres über das Pepton, Arch. ges. Physiol. (Pflüger's) 26, 515.

De waarde der physiologie voor den beoefenaar der ziektekunde, Inaugurale rede, Utrecht.

1882

Een geval van ziekelijke veranderingen in het ruggemerg bij pseudospierhypertrophie, Ned. Tijdschr. Geneesk. 18, 416.

Ein Fall von Rückenmarkserkrankung bei Pseudomuskelhypertrophie, Arch. path. Anat. (Virchow's) 89, 228.

Rudolf Virchow, Mannen van beteekenis. 
Met C.A.J.A. Oudemans, Saccharomyces capillitii, een spruitzwam van de behaarde hoofdhuid, Ned. Tijdschr. Geneesk. $21^{\mathbb{1}}, 997$.

Over den physischen grond van de diapedese der witte bloedlichaampjes bij ontsteking, Ned. Tijdschr. Geneesk. $21^{2}, 74$.

Over den invloed van chininezouten op den vaatwand bij ontsteking, Maandblad voor Natuurwetenschappen 12,85.

1886

Opmerkingen over de beteekenis der ziekteverschijnselen, Ned. Tijdschr. Geneesk. $22^{2}, 277$.

Sur la cause physique de la diapédèse des corpuscules blancs du sang en cas d'inflammation, Arch. néerland. des sciences exactes et naturelles 21, 34 . Met W.C. Mensonides, L'influence de l'hyperémie active sur le courant lymphatique, Arch. néerland. des sciences exactes et naturelles 21, 69. Ueber die Diapedese der farblosen Blutkörperchen bei der Entzündung, Arch. path. Anat. (Virchow's) 104, 242.

\section{7}

De beri-beri in Atjeh (Particuliere correspondentie), Ned. Tijdschr. Geneesk. $23^{1}, 633 ; 23^{2}, 276$.

Met C. Winkler, I. Mittheilung über die Beri-Beri, Deutsche Med. Wochenschr. 13, 845 .

\section{8}

Met C. Winkler, Onderzoek naar den aard en de oorzaak der beri-beri en de middelen om die ziekte te bestrijden, Utrecht, Kemink \& Zn.

Met C. Winkler, Recherches sur la nature et la cause du beri-beri et sur les moyens de le combattre, Paris, Bailliére et Fils.

Met C. Winkler, Erwiderung auf das Referat der Herrn Dr. Kitasato über unsere Mitteillung über Beri-Beri, Centralbl. Bakteriol. 2, 277.

Chemotactische werking van miltvuurbacillen op leucocyten van den kikvorsch, Handelingen Natuur- en Geneesk. Congres, Leiden, p. 125. 
Ueber Beri-Beri, X. Intern. Med. Congr. zu Berlin, Abt. XVI, Medizinische Geographie und Klimatologie, p. 1.

Over woekering van endotheliumcellen in slagaderen, Onderzoekingen *), 4 de reeks, 1,7 .

Chemotactische werking van miltvuurbacillen op leucocyten van den kikvorsch, Onderzoekingen, 4de reeks, 1, 77.

Vernieling van miltvuurbacillen door konijnenbloed, Versl. Kon. Akad. Wetensch. Amsterdam, 3de reeks, 7, 305.

*) ONDERZOEKINGEN, gedaan in het Physiologisch Laboratorium der Utrechtse Hoogeschool.

Eerste Reeks 1848-1856, Tweede Reeks 1867-1870, beide uitgegeven door F.C. Donders.

Derdle Reeks 1872-1889, uitgegeven door F.C. Donders en Th.W. Engelmann. Vierde Reeks 1891-1897, uitgegeven door Th.W. Engelmann en C.A. Pekelharing.

Vijfde Reeks 1897-1918, uitgegeven door C.A. Pekelharing en H. Zwaardemaker.

Zesde Reeks 1920-1928, uitgegeven door H. Zwaardemaker. Zevende Reeks 1932-1939, uitgegeven door A.K.M. Noyons. Achtste Reeks 1941-1965, uitgegeven door J. Jongbloed.

1891

Over vernieling van miltvuur virus in het onderhuidsbindweefsel van het konijn, Onderzoekingen, 4de reeks, $1,36$.

Over den aard van het fibrineferment, Onderzoekingen, 4de reeks, $1,77$. Ueber die Bedeutung der Kalksalze für die Gerinnung des Blutes, Internationaler Beitrag zur Rudolf Virchow's Festschrift 1, 433.

Ueber Beri-Beri, Handlungen des Med. Kongresses in Berlin, Abt. XVI, Zweite Sitzung.

De beteekenis van kalkzouten voor de stolling van het bloed, Versl. Kon. Akad. Wetensch. Amsterdam, 3de reeks, 9, 73, 395.

Over de samenstelling van het fibrineferment, Versl. Kon. Akad. Wetensch. Amsterdam, 3de reeks; 9, 293.

Ueber die Gerinnung des Blutes, Deutsche Med. Wochenschr. 18, 1133. 
Onderzoekingen over het fibrineferment, Onderzoekingen, 4de reeks, 2,1 . Over het neerslaan van eiwitstoffen door natriumsulfaat, Onderzoekingen, 4de reeks, 2, 278.

Ower het ,pepton" van Kühne, Onderzoekingen, 4de reeks, 3, 173. In memoriam Jacob Moleschott, Ned. Tijdschr. Geneesk. $29^{1}, 741$.

Over Kühne's pepton, Versl. Kon. Akad. Wetensch. Amsterdam, 1, 168. Ueber das Pepton Kühne's, Centralbl. Physiol. 7, 43.

Met G.C.J. Vosmaer, On Sollas' membrane in sponges, Onderzoekingen, 4de reeks, 3,185 .

\section{4}

Over de functie van het lymphoide weefsel, Geneesk. Bladen, eerste reeks, p. 1.

Over de betrekking van het fibrineferment van het bloedserum tot de nucleoproteide van het bloedplasma, Versl. Kon. Akad. Wetensch. Amsterdam, 3, 272.

Ueber die Beziehung des Fibrinefermentes aus dem Blutserum zum Nucleoproteid, welches aus dem Blutplasma zu erhalten ist, Centralbl. Physiol., 9,102 .

Lauis Pasteur, De Gids, 4de Serie „13 $3^{4}, 299$.

Over een nieuwe bereidingswijze van pepsine, Versl. Kon. Akad. Wetensch. Amsterdam 5, 25; Onderzoekingen, 4de reeks, 4, 170.

Over de betrekking van het fibrineferment uit het bloedserum tot de nucleoproteide, die uit het bloedplasma bereid kan worden, Onderzoekingen, 4de reeks, 4,1 .

Over het voorkomen van een nucleoproteide in spieren, Onderzoekingen, 4 de reeks, 4,185 .

Ueber eine neue Bereitungsweise des Pepsins, Zeitschr. physiol. Chem. 22, 233; Centralbl. Physiol. 10,696.

Ueber das Vorhandensein eines Nucleoproteids in Muskeln, Zeitschr. physiol. Chem. 22, 245.

Opmerkingen over het verschil tusschen levende en doode stof, Rectorale rede, Utrecht. 
Hypothesen aangaande de scheikundige samenstelling der levende stof, Ned. Tijdschr. Geneesk. 33 $3^{1}, 669$; Handelingen Ned. Natuur- en Geneesk. Congres te Delft, p. 20.

In memoriam Dr. S.K. Hulshoff, Ned. Tijdschr. Geneesk. $33^{1}, 565$.

\section{8}

Voorbereidend Onderwijs, Ned Tijdschr. Geneesk. $34^{1}, 357$.

Voorbereidend Hooger Onderwijs I, Ned. Tijdschr. Geneesk. 34 ${ }^{1}, 565$. Voorbereidend Hooger Onderwijs II, Ned. Tijdschr. Geneesk. 34, 605. Nieuwe onderzoekingen over maagsap, Album der Natuur, p. 129.

Met G.C.J. Vosmaer, Over het opnemen van voedsel bij sponsen, Versl. Kon. Akad. Wetensch. Amsterdam 6, 494.

\section{9}

In memoriam Tjalling Halbertsma, Utrechtsche Studenten Almanak, p. 103. Met G.C.J. Vosmaer, Over het opnemen van voedsel bij sponsen, Onderzoekingen, 5 de reeks 1,1 .

Met G.C.J. Vosmaer, De kraagcellen van sponsen, Onderzoekingen, 5 de reeks, 1,31 .

Eenige opmerkingen omtrent den tegenwoordigen stand der voedingsleer, Album der Natuur, p. 33.

\section{0}

Met W. Huiskamp, Over de eiwitstoffen van de glandula thymus, Versl. Kon. Akad. Wetensch. Amsterdam 9, 368.

Samenwerking van de spijsverteringsorganen, Album der Natuur, p. 193.

1901

On the proteins of the glandula thymus, Proc. Kon. Akad. Wetensch. Amsterdam 3,383 .

Het bindweefsel bij de oester, Onderzoekingen, 5 de reeks, 3,227 .

Mededeelingen over pepsine, Onderzoekingen, 5 de reeks, 3, 376.

Le tissue conjonctif chez l'huitre, ,Petrus Camper" 1, 228.

Mitteilungen über Pepsin, Zeitschr. physiol. Chem. 35, 8 .

Over den invloed van alcohol op de afscheiding van maagsap, Ned. Tijdschr. Geneesk. $38^{1}, 917$. 
In memoriam Prof. Rudiolf Virchow, Ned. Tijdschr. Geneesk. $38^{2}, 525$. In memoriam Barend Joseph Stokvis, Münch. Med. Wochenschr. 49, 1920. Over den invloed van alcohol op de gezondheid, Rede in den Volksbond tegen Drankmisbruik in 1902, gepubliceerd 1909.

Over pepsine, Versl. Kon. Akad. Wetensch. Amsterdam 10, 450.

De volksvoeding en de accijns op suiker, uitgegeven door den ,Anti SuikerAccijns Bond", bij J. Kuiken Jzn., te St. Anna Parochie, ook bij J.H. de Bussy, te Amsterdam.

\section{3}

De waarde van suiker als voedsel, uitgegeven door de Maatschappij tot Nut van 't Algemeen, gedrukt bij S.L. van Looy, te Amsterdam.

Met W. Huiskamp, Over den aard van het fibrineferment, Onderzoekingen, 5 de reeks, 4,451 .

Met W. Huiskamp, Die Natur des Fibrineferments, Zeitschr. physiol. Chem. $39,22$.

Ueber den Einfluss von mit Furfurol verunreinigtem Alkohol auf die Muskelarbeit, Onderzoekingen, 5de reeks, 4, 147.

Ueber den Einfluss des Alkohols auf die Absonderung des Magensaftes, Onderzoekingen, 5 de reeks, $4,156$.

1904

A propos de la pepsine, Arch. des sciences biologiques (Académie de SaintPétersbourg) 11,36 (Supplement Feestbundel voor I. Pawlow).

Het doctoraat in de geneeskunde, Ned. Tijdschr. Geneesk. $40^{1}, 481$.

1905

Aanteekeningen over pepsine, Onderzoekingen, 5de reeks, 5, 284.

Over onze kennis van de waarde der voedingsmiddelen uit chemische fabrieken, Ned. Tijdschr. Geneesk. $41^{2}, 111$.

Met C.J.C. van Hoogenhuyze en $H$. Verploegh, De afscheiding van kreatinine bij den mensch, Onderzoekingen, 5 de reeks, 6, 210; Versl. Kon. Akad. Wetensch. Amsterdam 14 ${ }^{1}, 215$.

Voordrachten over weefselleer, 1ste druk, Haarlem, de Erven F. Bohn.

\section{6}

Schetsen uit het leven, door Dr. D. Hüizinga, 3de druk, herzien door Dr. C.A. Pekelharing.

De rol van het vetweefsel bij de warmbloedige dieren, Album der Natuur, p. 241. 
De physiologie in Nederland in de laatste halve eeuw, Ned. Tijdschr. Geneesk. $51^{1}, 8$.

In memoriam W. Koster, Ned. Tijdschr. Geneesk. $51^{1}, 65$.

Over den invloed van alcohol op de cellen der maagkliertjes, Handelingen Elfde Vlaamsche Natuur- en Geneesk. Congres te Mechelen; p. 69; Onderzoekingen, 5 de reeks, 8, 290.

Met J.W.A. Gewin, De verhouding van pepsine tot chymosine, Versl. Kon. Akad. Wetensch. Amsterdam 16, 268.

\section{8}

Het verbruik van eiwit in het dierlijk lichaam, Ned. Tijdschr. Geneesk. $52^{2}$, 1663.

Ein Paar Bemerkungen über Fibrinferment, Biochem. Zeitschr. 11, 1.

Een paar opmerkingen over fibrineferment, Onderzoekingen, 5 de reeks, 9,1 .

Eiwit als voedsel, Geneesk. Bladen, 13 de reeks, p. 159.

In memoriam $\mathrm{Dr}$. J.H. Gallée, Utrechtsch Jaarboekje.

Het verbruik van eiwit in het dierlijk lichaam, gepubliceerd in: Voordrachten, gehouden voor de medische en natuurphilosophische studenten der Universiteit van Amsterdam, uitgaande van de Vereenigde Secties voor wetenschappelijken Arbeid, gehouden 30 Oct. 1908, in de Aula der Universiteit van Amsterdam.

\section{9}

Wettelijke regeling der vivisectie, De Gids $27^{4}, 328$.

Rapport der blijvende commissie voor het praktische en het aanvullende geneeskundig onderwijs, benoemd door het Hoofdbestuur der Ned. Maatschappij tot Bevordering der Geneeskunst, ingevolge het beshuit der Algemeene Vergadering van Dinsdag, 10 Juli 1906, Ned. Tijdschr. Geneesk. $53^{1}, 357$. Der Eiweiszverbrauch im Tierkörper, Zentralbl. ges. Physiol. und Path. des Stoffwechsels, Neue Folge, 4, 289.

Toespraak, gehouden bij de opening van het 12 de Nederlandsch Natuur- en Geneesk. Congres te Utrecht, Ned. Tijdschr. Geneesk. 531 1244.

Met C.J.C. van Hoogenhuyze, Over de vorming van kreatine in de spieren bij den tonus en bij de verstijving. Versl. Kon. Akad. Wetensch. Amsterdam, 18,521 ; Onderzoekingen, 5 de reeks, 11,1 .

De herdenking van Charles Darwin, Ned. Tijdschr. Geneesk. 532 1539. 
Met C.J.C. Hoogenhuyze, Die Bildung des Kreatins im Muskel beim Tonus und bei der Starre, Zeitschr. physiol. Chem. 64, 262.

Die Ausscheidung von parenteral zugeführtem Kreatin, Centralbl. Physiol. $24,814$.

Die Ausscheidung von parenteral zugeführtem Kreatin bei Säugetieren, Zeitschr. physiol. Chem. 69, 395 .

De afscheiding van buiten den darm om in het bloed opgenomen kreatine bij zoogdieren, Onderzoekingen, 5de reeks, 11, 236.

Over den invloed van alcohol op het maagslijmvlies, Onderzoekingen, 5de reeks, 11,222 .

\section{1}

Met W.E. Ringer, Zur elektrischen Ueberführung des Pepsins, Zeitschr. physiol. Chem. 75, 282.

Met W.E. Ringer, Bijdrage tot de kennis van de beweging van pepsine in het electrische veld, Onderzoekingen, 5 de reeks, $12,11$.

Over den invloed van alcohol op het magslijmvlies, Geneesk. Tijdschr. v. Ned.-Indië, Feestbundel, p. 85.

Een onrechtvaardig oordeel, Ned. Tijdschr. Geneesk. 55, 2109.

In memoriam Prof. Thomas Place, Ned. Tijdschr. Geneesk. $55^{2}, 689$.

Over de afscheiding van kreatine bij den mensch onder de invloed van spiertonus, naar proeven van J. Harkink, Versl. Kon. Akad. Wetensch. Amsterdam $20^{1}, 178$; Onderzoekingen, 5 de reeks, 12,30 .

Met J. Harkink, Die Kreatininausscheidung beim Menschen unter dem Einflusz vom Muskeltonus, Zeitschr. physiol. Chem. 75, 207.

Over den invloed van eenige anorganische zouten op de werking van pancreaslipase, Onderzoekingen, 5de reeks, 13, 16; Versl. Kon. Akad. Wetensch. Amsterdam $21^{1}, 289$.

Ueber den Einfluss einiger anorganischen Salze auf die Wirkung der Pankreaslipase, Zeitschr. physiol. Chem. 81, 355 .

Influence of some inorganic salts on the action of the lipase of the pancreas, Proc. Kon. Akad. Wetensch. Amsterdam 15, 336. 
Over de eischen door het menschelijk lichaam aan het voedsel gesteld, Rede, uitgesproken op het Congres voor Openbare Gezondheidsregeling, Tijdschr. Soc. Hygiëne 15, 198.

Das Aktivieren von Blutserum, Zeitschr. physiol. Chem. 85, 341 .

Ueber die von Herrn Oskar Schultze behauptete Kontinuität von Muskelfibrillen und Sehnenfubrillen, Anat. Anzeiger 45, 104.

De vorming van kreatine in de willekeurige spieren wan gewervelde dieren bij den tonus, Ned. Tijdschr. Geneesk. $57^{2}, 623$.

Met C.J.C. van Hoogenhuyze, Ueber die Cammidgesche Pankreasreaktion, Zeitschr. physiol. Chem. 91, 151.

Geneeskunde en Geneeskunst, Ned Tijdschr. Geneesk. $58^{1}, 1885$.

Het activeeren van bloedserum, Onderzoekingen, 5de reeks, 14, 118.

Ueber den Einflusz von Phophatiden auf die Blutgerinnung, Zeitschr. physiol. Chem. 89, 22 .

Een paar opmerkingen over den strijd tegen het gebruik van opium in Nederlandsch-Indië, Vragen des Tijds 1, 315 .

Met C.J.C. van Hoogenhuyze, Over de reactie van Cammidge, Onderzoekingen, 5de reeks, 15, 288.

Een woord van hulde aan Dr. E.D. Cartier van Dissel, Ned. Tijdschr. Geneesk. $59^{1}, 489$.

In memoriam Dr. E.D. Cartier van Dissel, Ned. Tijdschr. Geneesk. 59² 713. In memoriam Dr. J.F.Ph. Hers, Ned. Tijdschr. Geneesk. 592, 1727.

\section{6}

In memoriam Iwan Petrowitsch Pawlow, Ned. Tijdschr. Geneesk. $60^{1}, 813$. Met C.J.C. van Hoogenhuyze, Over eenige nieuwe waarnemingen omtrent het verband tusschen den spiertonus en het gehalte der spieren aan kreatine, Versl. Kon. Akad. Wetensch. Amsterdam 24(II), 1577 ; Onderzoekingen, 5de reeks, 17,1 .

In memoriam G.C.J. Vosmaer, Ned. Tijdschr. Geneesk. $60^{2}, 1269$.

Aanwijzingen, die de voedingsleer aan de hand doet, om het gebrek aan levensmiddelen zoo min mogelijk schadelijk te doen zijn, Rede, uitgesproken 
op het Gezondheidscongres te Leeuwarden op 16 September 1916, Tijdschr. soc. Hygiëne $18,229$.

Met W. Schut, Onderzoek naar de voedingswaarde van geharde vetten, Chem. Weekblad 13,755; Onderzoekingen, 5de reeks, 17, 26.

Met W. Schut, Examen de la valeur nutritive des graisses durcies, Arch. néerl. physiol. 1,635 .

\section{7}

Over de vraag, of naast pepsine een ander enzym, chymosine, moet worden aangenomen, Onderzoekingen, 5de reeks, 18, 212 .

Voordrachten over weefselleer, 2 de druk, Haarlem, de Erven F. Bohn.

Ueber die Frage, ob neben dem Pepsin ein anderes Enzym, Chymosin, anzunehmen ist, Arch. ges. Physiol. (Pflüger"s) 167, 254.

Franciscus Cornelis Donders, Rede, gehouden 27 Mei 1918 in de Aula der Rijksuniversiteit te Utrecht, Janus 24, 1919.

\section{8}

Toespraak, gehouden bij het afscheid van het onderwijs aan de Rijksuniversiteit te Utrecht, Ned. Tijdschr. Geneesk. $62^{1}, 1680$.

Prof. C. Winkler 25 jaar hoogleeraar, 20 September 1892 - 20 September 1918, Ned. Tijdschr. Geneesk. $62^{2}, 917$.

\section{9}

Some remarks on enzymes, Rec. trav. botan. néerland. 16, 207.

1920

Jan Salie leeft nog, Vragen des Tijds 47, 33 (onder pseudoniem Jan Vrijheid).

1921

In memoriam Hector Treub, Janus 25, 51.

Geschiedenis van de Vereenigde Gods- en Gasthuizen te Utrecht van 1817 . 1917, Utrecht.

Over de beweging van pepsine in een al of niet eiwitbevattende gel van agaragar, Versl. Kon, Akad. Wetensch. Amsterdam 30, 309.

On the movement of pepsin in a protein-containing or proteinfree gel of agaragar, Proc. Kon. Akad. Wetensch. Amsterdam 24, 269. 
Rede ter gelegenheid van de onthulling van het monument te nagedachtenis van Prof. F.C. Donders, gehouden in het Groot-Auditorium der Rijksuniversiteit te Utrecht op 27 Mei 1918, ter gelegenheid van den 100sten verjaardag van Donders' geboorte, uitgegeven bij J. van Druten te Utrecht.

1922

F.C. Donders, Lebensbeschreibung und Rede bei der Enthüllung des Denkmals, Leipzig, Wilhelm Engelmann. 


\section{GERAADPLEEGDE LITERATUUR}

*ADELMANN, H.B. Marcello Malpighi and the evolution of embryology. Ithaca N.Y. Cornell Univ. Press 1966, pp 311-313, 651-653.

*ALBERTONI, P. Ueber die Wirkung des Pepsins auf das lebende Blut. Centr.Bl.f.d.Med.Wiss. 1878

*ALBERTONI, P. Rendiconto delle Richerche sperimentali escquite nel gabinetto di fysiologia. Della R.Universita di Siena. 1878.

*ALBUCASIS. Cap. XV. De passione fluxus sanguinis a quocu que locorum. In Liber theoricae nesnon practicae Alsaharavii qui vulgo Acararius dicitur. Auguste Vindelicorum. S. Grimm en M. Vuissung, 1519, folia $145^{\prime}$

*ALEXANDER, B. Coagulation, hemorrhage and thrombosis. New England J. Med. 252, 1955. p 432, 484, 526.

*ANDERSON, Andrew. On the state in which fibrin exists in the blood. Proc. of Glasgow Phil.Soc. 1844. Vol. 1, p 201.

ANDRAL. G. Précis d'anatomie pathologique. Paris 1829, 3 Vol. in 8.

ANDRAL, G. Clinique médicale. $3 e$ ed. Paris 1835.5 Voll. in 8.

*ARISTOTELES. Meteorologica boek IV. Chap. VII p. 335, Chap. X p.365 The Loeb Classical Library, Harvard Univ. Press 1952. Cambridge, Mass. U.S.A.

*ARTHUS, M., G. PAGES. Nouvelle théorie chimique de la coagulation du sang. Arch. Physiol. Norm. Path. 22 (1890), pp 739-746.

ARTHUS, M. La coagulation du sang. C. Carre en C. Naud. Paris 1899. 208 
*ARTHUS, M. La pllasma fluoré, reactif du fibrin ferment. Journ. de Phys. et de Path. gen. III 1901, pp 887-900.

*ARTHUS, M. Application à l'étude de la vitesse de la production du fibrinferment dans le sang extrait des vaisseaux. Journ. de Phys. et de Path. gen. IV, 1902. p. 1-11.

*ARTHUS, M. Sur la vitesse de la coag. du sang des prises successives. Journ. de Phys. et de Path. gen. IV, 1902. p. 273-276.

*ARTHUS, M. Recherches sur la coagulation extravasculair du sang. Journ. de Phys. et de Path. gen. IV. 1902. p. 281-288.

*ARTHUS, M. La coagulation du sang. Scientia Biologie nr. 5. Evreux, imprimerie de Charles Hérissey, 1907.

*ARTHUS, P, Th. CHAPIRO' Etudes sur la rétraction du caillot sanguin. Arch.Int.Physiol. VI (1908) pp 298-305.

*ARTHUS, M., KOSLOVA, N. Etudes physiologiques sur un hémostatique le liquide de capodieci. Arch.Int.Physiol. VI (1908) pp 73-80.

ASTRUP, T. and PERMIN, P.M. Fibrinolysis in the animal organism. Nature (London)159, 1847, p. 681.

ASTRUP, T. Blood Clotting and Related Processes. In Nord, F.F. (Ed.). Advances in Eurymology and Related Subjects of Biochemistry, New York: Interscience Publishers, Inc., 1950. Vol. 10, pp 1-49.

ASTRUP, T. Role of Blood Coagulation and Fibrinolysis in the Pathogenesis of Arteriosclerosis. New York: Acad. Press Inc. 1959, pp 223-240.

* BAART dE LA FAILLE c.s. Leven en werken van Comelis Adrianus Pekelharing. Utrecht 1948.

BARTON, P.G., JACKSON, C.M. and HANAHAN, D.J. Relationship between Factor $\mathrm{V}$ and activated Factor $\mathrm{X}$ in the generation of prothrombinase. Nature (London) 214, 1967. p. 923.

BECK, E.A. Die klassische Blutgerinnungstheorie. Thesis (M.D.) Zürich 1965.

BECK, E.A. Historical development of the prothrombin concept. Handbook of haemophilia 1975 . 
BECK, E.A. Prothrombin and related coagulation factors. In Boerhaave Series nr. 10. Ed. by Hemker H.C., Veltkamp, J.J. Leiden Univ.Press 1975.

BETTELHEIM, F.R. and BAILEY, K. The products of the action of thrombin on fibrinogen. Biochem. et biophys. acta 9.1952. p. 578 .

BIGGS, R., and MACFARLANE, R.G. Human Blood Coagulation and Its Disorders (3rd Ed.). Oxford, Engl.: Blackwell Scientific Publications 1962 (a). p. 112.

* BIGGS, R. Forty years of the one-stage prothrombin time. TDH 33 (1975), pp 139-149.

BIGGS, R. Human blood coagulation, Haemostasis and Thrombosis. Ed. by Rosemary Biggs Sec. Ed. 1976. Blackwell Scientific Bibl. Oxford.

BIGGS, R. and MACFARLANE, R.G. The evolution of the haemostatic mechanism. Ed. als boven 1977. pp 639-654.

*BISCHOFF, Th.L.W. Beiträge zur Lehre von dem Blute und der Transfusion desselben. Müllers Archiv (1835), pp 347-372.

*BIZZOZERO, G. Ueber einen neuen Formbestandteil des Blutes und dessen Rolle bei der Thrombose und der Blutgerinnung. Virchow's Arch.Path.Anat. 90 (1882), pp 261-333.

*BIZZOZERO, G. Sur un nouvell élement morphologique du sang chez les mammifères et sur son importance dans la thrombose "et dans la coagulation. Archiv Ital.Biol. 1882, pp 345-362.

BLUM, A.L. Annotation: Coagulation factor variants. Br.J.Haematol. 23,1972, p. 643 .

"BL,UM, L. Neuere Arbeiten über Blutgerinnung. Centr.Blatt für Allgemeinen Pathologie und Path .Anatomie XV (1904), pp 385-401.

*BORDET, Jules. The theories of blood coagulation. Bibll. of the Johns Hopkins Hospital, jrg. 32 (1921), pp 213-218.

*BORDET, J. et DELANGE, L. La question du rôle des lipoides dans la coagulation du sang. Berliner Klin. Wöchenschrift 1914.

*BORDET, J. et DELANGE, L. La coagulation du sang et la genèse de la thrombine. Ann. de l'Inst. Pasteur 65, 1912. pp 657-674, 737-766. 
*BORDET, J. et GENGOU, O. Recherches sur le coagulation du sang. Ann. de l'Inst. Pasteur XVII (1903), pp 822-833.

*BORDET, J. et GENGOU, $O$. Sur le pouvoir coagulant du sérum. Ann. de l'Inst. Pasteur XVIII (1904), pp 98-117.

BORDET, J. et DELANGE, L. La question du röle des Lipoides dans la coagulation du sang. Berliner Klin. Wochenschrift 1914.

*BORDET, J. Considérations sur les théories de la coagulation du sang. Ann. de l'Inst. Pasteur par E. Duclaux (Bruxelles). Masson et Cie. Ed. (1920), pp 561-595.

BOROVICZENY c.s. Einführung i.d. Geschichte der Hämatologie. Georg Thieme Verlag Stuttgart, 1974.

BOWIE, E.J.W., THOMPSON, J.H. jr. and OWEN, C.A. jr. A new abnormality of platelet function. Thromb.Diath.Haemorrh. 11, 1964. p. 195.

BOWIE, E.J.W., THOMPSON, J.H.jr., DIDISHEIM, P. and OWEN, C.A. jr. Disappearance rates of coagulation factors: Transfusion studies in factor-deficient patients. Transfusion 7, 1967. p. 174.

BRINKHOUS, K.M., SMITH, H.P., WARNER, E.D. and SEEGERS, W.H. The inhibition of blood clotting. Am.J.Physiol. 125, 1939. p. 683.

BRINKHOUS, K.M. A study of the clotting defect in hemophilia: The delayed formation of thrombin. Am.J.Med.Sci. 198, 1939. p. 509.

BRINKHOUS, K.M., PENICK, G.D., LANGDELL, R.D., WAGNER, R.H., GRAHAM, J.B. Physiologic basis of transfusion therapy in hemophilia. Arch.Pathol. 61, 1956. p.6.

BRINKHOUS, K.M. The development of our knowledge of hemophilia A en B. Scr.Haematol. 7, 1965.p. 1.

*BRUECKE, E. Ueber die Ursachen der Gerinnung des Blutes. Archiv Path. Anat. 12 (1857), pp 81-100 en 172-196.

*BRUECKE, E. Ueber das Verhalten einiger Eiwisskörper gegen Borsaure. S.B. Kaiserl.Akad.Wiss.Math.Naturwiss. Klasse 15:2, 1867.pp 881-904. 
* BUCHANAN, A. Contributions to the physiology and pathology of the animal fluids. London Med.Gaz. 18 (1836), pp 50-54.

* BUCHANAN, A. Original communications on the coagulation of the blood and other fibriniferous liquids. London Med. Gaz. 1845.

BUDTZ-OLSEN, O.E. Clot Retraction. Springfield III. Charles C. Thomas Publisher, 1951 .

* BUESS, H. Zur Geschichte des Emboliebegriffs bis auf Virchow. Schweizerisches Medizinisches Jahrbuch 1946, pp LVII-LXX.

*BUESS, H. Zur Entwicklung der Thromboselehre im 18. Jahrhundert. Schweiz.med.Wochenschr. 29 (1954), pp 776-788.

BUÉSS, H. Recherches, découvertes et inventions de médicins suisses. Introduction biographique et bibliographique. Editể par Ciba S.A. Bâle, Z.j.

*BUERKER, K. Blutplättchen und Blutgerinnung. Pflügers Archiv ges. Physiol. $102,1904 \ldots$

CHEN, R. and DOOLITTLE, R.F. y-y Cross linking sites in human and bovine fibrin. Biochemistry 10, 1971.p. 4486.

CLAUSS, A. Gerinnungsphysiologische Schnellmethode zur Bestimmung des Fibrinogens. Acta Haematol. 17. 1951. pp 237 e.v.

*CHATTERJEA, J.B. Blood platelets and thrombosis. J. Indian Med.Ass. 54, 1970. pp 516-518.

*CRAMER, C.D. Over de zoogenaamde Thrombosine van Lilienfeld. Onderz.v.h.Phys.Lab. te Utrecht. 1897.

*VAN CREVELD, S. e.a. Significance of clotting factors in blood platelets, in normal and pathol. conditions. Lancet jrg. 2, 1951. pp 242-244.

DAM, H. SCHONHEYDER, F. and TAGE-HANSEN, E. Studies on the mode of action of vitamin K. Biochem.J. 30, 1936. p 1075.

DAM, $H$, and GLAVIND, J, Vitamin $K$ in human pathology. Lancet 1, 1938, p. 720. 
DASTRE, A. Fibrinolyse dans le sang. Arch Physiol. 5 (Ser. 5), 1893. p. 661 .

DEGGELLER, $\mathrm{K}$. and VREEKEN, J. The human prothrombin-activating enzyme. Thromb.Diath.Haemorrh. 22, 1969, p.45.

*DELEZENNE, M.C. Préparation d'un plasma pur et stable par simple centrifugation du sang d'oiseau. Ste. de Biol. Seance du 18 Juillet. Compt. Rendus de 1'Acad. des Sciences 1896. pp 782-785.

*DELEZENNE, M.C. Recherches sur la coagulation du sang chez les oiseaux. Arch.Physiol.Norm.Path. Paris, 1897. pp 333-346.

*DELEZENNE, M.C. Activation du suc punc et coag. du sang. Ann. de Physiol. et de Physicochemie, jrg. 2, 1926. pp. 531-541.

DENIS, S. Recherches expérimentales sur le sang humain considéré à l' état sain. Paris, 1831.

DENIS, P.S. Nouvelles études chimique physiol. et medic. sur les substances albuminoides. Paris, 1856.

DENIS, P.S. Mémoire sur le sang considéré quand il est fluide, pendant qu'il se coagule et lorsqu'il est coagulé. Paris, J.B. Bailltère, 1859.

*DONNE, A. De l'origine des globules du sang, de leur mode de formation et de leur fin. C.R. Acad.Sci. (D). Paris Bd. 14, 1842. p.366 e.v.

DEUTSCH, E. (ed.). Blood clotting factors. Proc. 4th Intern.Congres of Biochemistry, New York, Pergamon Press, 1959.

DE KREKER, R.A. Fibrin Stabilizing Factor (FSF). In Hunter, R.B., Koller, F., and Beck, E. (Eds.) Fibrinogen and Fibrin: Turnover of clotting factors. Stuttgart: Schat tauer. 1964.pp 411-418.

DUCKERT, F., FLUECKIGER, P., MATTER, M. and KOLLER, F. Clotting Factor X. Physiologie and physico-chemical properties. Proc.Soc.Exp.Biol.Med. 90. 1955.p.17.

*EAGLE, Harry. The role of prothrombine and platelets in the formation of thrombine. J.Gen.Physiol. (18). 1935. pp 531-555. 
*EBERT, J.C. en SCHIMMELBUSCH, C. Experimentelle Untersuchungen über Thrombose. Virchow's Arch Path.Anat. Irg. 103, 1886. pp 39-87.

EBERT, C.J. and SCHIMMELBUSCH, C. Die Thrombose nach Versuchen und Leichenbefunden. Stuttgart, Ferdinand Enke. 1888.

*EGUET, J. Ueber den Einfluss des Blutegelinfuses auf die Thrombenbildung. Basel, 1894. pp 217-248.

EHRSTROEM, R. Olaf Hammarsten. Finsk.Lakaresallsk.Handl. 75. 1933. p.25.

ENGELMANN, Th.W. en PEKELHARING, C.A. Onderzoekingen gedaan in het Lab. der Utrechtsche Hoogeschool. Vierde reeks. 1891-'97.

*FERGUSON, J.H. An experimental analysis of coagulant achevity. Am.J. Physiol. 117. 1936. pp 587-595.

FERGUSON, J.H. An intermediary calcium complex in blood coagulation. Am.J.Physiol. 119. 1937. p.755.

FIESER, L.F. Synthesis of vitamin K. J.Am.Chem.Soc. 61. 1939. p.3467.

FLYNN, J.E. and COON, R.W. Purification and isolation of certain intermediates formed prior to the activation of prothrombin. Am.J.Physiol. 175. 1953. p.289.

*FONIO, A. Neuere Untersuchungen über Blutgerinnung. Schweiz.med. Wochenschr. 1922. pp 36-41.

*FONIO, A. Neuere Untersuchungen über Blutgerinnung. Schweiz.med. Wochenschr. 1923. pp 60-64.

*FONIO, A. Beob. über d. Gerinnung u. Thrombose. Vorgang im Dunkelfeldnativpräparat. Schweiz.med.Wochenschr. 1940. pp 510-514.

*FONIO, A. Die retraktionsauslösende Function der menschlichen Thrombocyten in physiologischer u. pathologischer Hinsicht. Bull.Schweiz. Akad.Med.Wiss. 4. 1948. pp 470-481.

*FONIO, A. Die Gerinnungsfaktoren bei der Hämophilie. Basel, Benno Schabe en Co. 1961. pp 145-175. 
FORGET, C. De l'humorisme rationnel. Journ thebd. 1834-1835.

*FRANK, E. Die essentielle Thrombopenie. (Konstitutionelle PurpuraPseudo Hämophilie). I. Klinisches Bild. II. Pathogenese. Berliner Klin. Wochenschrift 52. 1915. pp 454-458.

*FREDERICQ, Léon. Une nouvelle propriété optique du sang des mammifères. pp 61-62.

*FREUND, E. Ein Beitrag zur Kenntnis der Blutgerinnung. Med.Jahrb.Gesellschaft Aertze. Wien, 1886.

*FREUND, E. Ueber die Ursache der Blutgerinnung. Wien.Med Jahrbuch 1888. I: pp 259-279. II: pp280-302.

*FULD, E. Ueber das Zeitgesetz des Fibrinfermentes. Beitr.Chem.Physiol. Path. 2. 1902. pp 514.527.

*FULD, E. Einige neue Arbeiten über Fibrinferment. Bioch.Centralblatt I, 1903. pp 129-132.

*FULD, E. Ueber die Vorbedingungen der Blutgerinnung sowie über die Gerinnbarkeit des Fluorplasmas. Zentralblatt der Physiologie. Bd XVII no. 19. 1903. pp 529-533.

*FULD, E. und SPIRO, K. Der Einfluss einiger gerinnungshemmender Agentien auf das Vogelplasma. Beitr.Chem.Physiol.Path. 5, 1904. pp 171 e.v.

GAARDER, A., JONSEN, J. LALAND, S., HELLEM, A. and OWSEN, P.A. ADP in red cells as a factor in the adhesiveness of human blood platelets. Nature (London) 1961.p.531.

*GLANZMANN, E. Hereditäre hämorrhagische Thrombasthenie. Ein Beitrag zur Pathologie der Blutplättchen. Jahrb.Kinderheilkunde 88. 1908. pp 113-141.

GRAHAM, J.B. Biochemical genetics of blood coagulation. Am.J.Hum. Genet. 8. 1956. p.63.

GREEN, P. Journ.of Physiol.Vol. IV. 1883. pp 380 e.v.

*GREEN, J.R. On certain points connected with the coag. of the blood. Journ. of Physiol,,Vol. VIII, 1887. pp. 354-377. 
GROSS, R., GEROK, W., LOEHR, G.W., VOGELL, W., WALLER, H.D. and THEOPOLD, W. Ueber die Natur der Thrombasthenie: Thrombopathie Glanzmann-Naegeli. Klir w/grignschr. 38. 1960. p. 193.

HAANEN, C. Bloedstelping en bloedstollingsonderzoek. A'dam, Scheltema en Holkemia. 1971.

HALLER, VON. Albrecht. Elementa physiologiae corporis humani. Lau* sanne 1757-1763.

HAMMARSTEN, O. Zur Lehre von der Faserstoffgerinnung. Pflüger's Archiv ges.Physiol. Bd. 14, 1874. pp 211.273.

*HAMMARSTEN, O. Untersuchungen über die Faserstoffgerinnung. Soc. der Wiss. Uppsala. 1875. pp 1-130.

*HAMMARSTEN, O. Zur Lehre von der Faserstoffgerinnung. Arch.f.d.ges. Physiologie des Menschen und der Tiere. Bd. 14. Bonn, Max Cohen Verlag. 1877. pp 211-273.

*HAMmarsten, O. Ueber das Paraglobulin. Arch.f.d.Gesammte Physiol. d.Menschen u.d.Tiere. Bd. XV. 1878. pp 38-116.

*HAMMARSTEN, O. Ueber das Paraglobulin. Arch.f.d.Ges.Physiol.d. Menschen u.d.Tiere. Bd. XV. 1878. p. 38 e.v.

HAMMARSTEN, O. Ueber das Fibrinogen (1e Abschnitt). Pflüger's Archiv ges.Physiol. 19. 1879. p. 563.

HAMMARSTEN, O. Ueber das Fibrinogen (2e Abschnitt). Pflüger's Archïv ges.Physiol. 22. 1880. p. 431.

*HAMMARSTEN, O. Ueber die Bedeutung der löslichen Kalksalze für die Faserstoffgerinnung. Zeits.Physiol.Chemie. Bd. 22. 1896. pp 333-395.

*HAMmaRsteN, O. Ueber das Verhalten des Paracaseins zu dem Labenzyme. Ztschr.für Physiol.Chemie. Bd. XXVI. 1896. pp 103-126.

HARMISON, C.R., and MAMMEN, E.F. Molecular Characteristics of Substances Active in Blood Coagulation. In Seegers W.H.(Ed.). Blood Clotting Enzymology. New York. Acad.Press Inc. 1967. pp 23-101.

HARVEY, W. Exercitationes de generatione animalum Exercit. 52. London 1651 . 
HARVEY, W. The works of William Harvey, M.D. Translated From the Latin With a Life of the Author by Robert Willis, London, The Sydenham Society. 1847.

HAYEM, G. Nouvelle contribution a l'étude des concrétion sanguines intravasculaires. C.R.Acad.Sci.(D) Bd. 97. Paris, 1883. pp 144 e.v.

*HAYEM, G. Du sang et de ses altérations anatomiques. G. Masson Ed. Paris, 1889. pp 207-329.

*HAYEM, G. Du caillot non rétractile. Comptes Rendus etc. Jrg. 123. 1896. pp 894-896.

HEILBRUNN, L.V. The evolution of the haemostatic mechanism. Uit: Functions of the blood. R.G. MacFarlane and A.H.T. Robb-Smith, Eds. Academic Press, 1961. pp 283-301.

HEKMA, E. Ueber das Fibrin und seine Beziehung zu einigen Problemen der Biologie und der Kolloidchemie. Büochem.Z. 62. 1914. pp 161 e.v.

HEKMA, E. Ueber der Reversibilität der in flüssig erhaltenen Plasma und Transsudaten anscheinend spontan und unter Serumeinflusz sich bildenden Gele. Biochem.Z. 63. 1914. pp 204 e.v.

HEKMA, E. Ueber Gelbildung in flüssig erhaltenem Plasma. Biochem.Z. 64. 1914. pp 86 e.v.

HEMKER, H.C., VELTKAMP, J.J. and LOELIGER, e.a. Kinstic aspects of the interaction of blood clotting enzymes III. Thromb.Diath.Haemorrh. 19, 1968. p.346.

*HEWSON, W. Vom Blute, seinen Eigenschaften und einigen Veränderungen desselben. Nürnberg, 1780 . Vert. van Exp. inquiry into the properties of Blood. 3e ed. Johnson, J. London, 1780.

HEWSON, W. Disquisitio experimentalis de sanguinis natura. London, 1785.

*HYORTH, P., RAPAPORT, S., e.a. Evidence that Platelet Accelerator (P. F.C.) is absorbed plasma proaccelerin. Blood Jrg. 10, 1955. pp 1139. 1149 .

*HOME, E. On the changes the blood undergoes in the art of coagulation. Philosoph.Trans.Roy.Soc. London, 1857. The Croonian Lecture. 
*HOME, E. Some additions to the Croonian Lecture, on the changes the blood undergoes in the act of coagulation. Philosoph.Trans.Roy.Soc. 108, XII. London, 1818. pp 172-185, 185-198.

*HOPPE-SEYLER, F. XI Beiträge zur Kenntnis usw. 1877. pp 169-208.

*HOPPE-SEYLER, F. XXXV Beiträge zur Kenntnis usw. 1881 . pp 366-385.

*HOPPE-SEYLER, F. LIII Beiträge zur Kenntnis usw. 1882: pp 523-549.

*HOWELL W.H. The role of antithrombin and thromboplastin in the coagulation of blood. Am.J.Physiol. 29.1911. pp 187 e.v.

*HOWELL, W.H. The nature and action of the thromboplastic (zymoplastic) substance of the tissues. Am.J Physiol. 31. Vol. XXXI, 1912. pp 1-21.

*HOWELL, W.H. Structure of the fibrin-gel and theories of gel formation. Am.J.Physiol. 40, 1916. pp 526-546.

*HOWELL, W.H. Two new factors in blood coag. Heparin and pro-antithrombin. Am.J.Physiol. Vol. 47, 1918. pp 328-341.

*HOWELL, W.H. The purification of heparin and its chemical and phys. reactions. Bull. Johns-Hopk.-Hosp. Vol. 42. 1928. pp 199-206.

*HOWELL, W.H. Theories of blood coagulation. Physiol.Rev. 15. 1935. pp 435-470.

*HUISKAMP, W. Over het meerslaan van de serumglobuline in het bloedserum d.m.v. arynrum. Onderz.v.h.Phys.Lab. te Utrecht. 1905.

*HUISKAMP, W. Enige opmerkingen aangaande de aanwezigheid van fibrineglobuline in fibrinogeenoplossingen. Onderz i.h.Phys.Lab. te Utrecht. 1905 .

HUNTER, J. A treatise on the blood, inflammation and gun-shot wounds. London, 1795. In 4 New ed. 1828 in 8.

JAQUES, L.B. Bloodclotting and hemostasis. Ann.Rev.Physiol. 16. 1954. p.175.

JONES, A.F.D. A treatise on the process employed by nature in suppress- 
ing its haemorrhage of divided and punctured arteries and the use of the ligature. Longman, Hurst, Rees, Orms and Brown. London. 1810.

*KOEHLER, A. Ueber Trombose und Transfusion, iter- und septische Infection und deren Beziehung zum Fibrinferment. Dissertation. Dorpat Univ. 1877.

*KOSSEL, A. Neuere Untersuchungen über die Blutgerinnung. Berliner Klin.Wochenschrift 21. 1893.pp 498-501.

*KOWALSKI, E. and NIEWIAROWSKI, S. Biochemistry of Blood Platelets. Academic Press Inc. New York. 1967.

*KRUEGER VON. F. Die Gerinnung des Blutes. Handb.d.Verg.Phys. 1925. pp 1312-1321.

*LANGEMEYER, H.G. Onderzoekingen over bloedplaatjes. Onderz.v.h. Phys.Lab. te Utrecht.1916.

LATSCHENBERGER und STRAUCH. Diss. Dorpat, 1889.

*LEGLER, R.G. Ueber die Kinetik der Blutgerinnung. Helvetica Chirurgica Acta, 26. 1943. pp 1512-1552.

LEHMANN, C.G. Lehrbuch der physiologischen Chemie. Blutgerinnung, pp 185-200.

*LE SOURD, L. et PAGNIER, Ph. Recherches sur le rôle des plaquettes sanguines ou hématoblastes dans la coagulation du sang. Journ.de Phys. et de Path.gen. 11 (1909), pp 1 e.v.; 13 (1911), pp 56 e.v.; 15 (1913), pp 812 e.Y.

* LE SOURD, L. et PAGNIER, Ph. La rétraction du caillot sanguin et les plaquettes. Journ.de Phys.et de Path.gen. 15. 1913. pp 825 e.v.

LISTER, J. On the coagulation of the blood. The Croonian Lecture. Proc. Roy.soc. London, 1863.

LOEB, Leo. Weitere Untersuchungen über Blutgerinnung. Beitr.Chem. Physiol.Path. V. 1905. pp 534-557.

MAGENDIE ,F. Mémoires sur le méchanisme de l'absorption chez les animaux à sang rouge et chaud. J Physiol. exp Path. 1821. pp 1-17, 18-31. 
* MALPIGHI, M. De polype cordis. De pulmonibus epistolai. In Opera Omnia, London, 1686. Quoted from a reprint published by Almquist and Wiksells, Stockholm (1956). pp 123-139, 133-139.

*MELLANBY, John. Prothrombase, its preparation and properties. Proc. Roy.Soc.of London. Vol. CVIL. Series B. 1931.

*MORAND, S.F. Mem.Acad.Roy.Chir. 8, 1736.

*MORAND, M. Sur un moyen d'arrêter le sang des Artères, sans le secours de ligature. Mem.Roy.Chir. 22. 1753. pp 220-232. 220-232.

*MORAWITZ, P. Zur Kenntnis der Vorstufen des Fibrinferments. Beitr. Chem.Physiol.Path. IV. 1904. pp 381-420.

*MORAWITZ, P. Beiträge zur Kenntnis der Blutgerinnung. Deutsches Archiv für Klin. Medizin. Bd. 29. 1904. pp 1-28.

*MORAWITZ, P. Aus der midizinischen Klinik in Tübingen. Beiträge zur Kenntnis der Blutgerinnung. In Deutsches Archiv für Klin.Medizin, Bd. 79, 1904. pp 432-442.

*MORAWITZ, P. Die Chemie der Blutgerinnung. Ergebnisse der Physiologie 4,1905 . pp 307-422.

*MORAWITZ, P.: Blut und Lymphe. In Handbuch der Biochemie des Menschen u.d. Tiere. Gustav Fischer Verlag, Jena. 1925. pp 44-126.

*MUELLER, J. Beobachtungen zur Analyse der Lymphe, des Blutes und des Chylus. Ann. der Physik u. Chemie. Jrg. 101 (25). 1832. pp 513591.

*MUELLER, J. Handbuch der Physiologie des Menschen. Mikrosk .-mechanische Analyse des Blutes. Coblenz, 1835. pp 96-152.

*NOLF, P. La coagulation du sang des poissons. Arch.Int Physiol. IV. 1906. pp 216-259.

*NOLF, P. Contribution à l'étude de la coagulation du sang. (1e)Arch. Int.Physiol. IV. 1906/7. pp 165-215.

*NOLF, P. Contribution à l'étude de la coagulation du sang. Les facteurs primordiaux, leurs origine. (3e). Arch.Int.Physiol. VI. 1908. pp 1-72. 
* NOLF, P. La formation de la fibrine (4e). Arch.Int.Physiol. Bd. VI. 1908. pp 115.191.

*NOLF, P. Contribution à l'étude de la cọgulation du sang. La fibrinololyse. (5e). Arch.Int.Physiol. Bd. VI. 1908. pp 306-359.

NOLF, $P$. et HERRY, A. De l'hëmophilie pathogène et traitement. Rev. méd. 29. 1909. pp. 841 e.w.

NOLF, P. et HERRY, A. De l'hémophilie pathogène et traitement. Rev. méd. 29. 1910. pp 106 e.v.

NOLF, P. Eine neue Theorie der Blutgerinnung. Ergebn.inn Med.Kinderheilk. 10. 1913.pp 275 e.v.

*NOLF, P. De l'obtention de la thrombozyme à l'état de pureté. Comp. Rend.Société Belge 84. 1921.pp 840-843.

*NOLF, P. Préparation et propriétés coagulantes de la thrombozyme. Arch. Int.Physiol. Vol. 55 Fase 3. 1948. pp 288-289.

DEN OTTOLANDER, G.J.H., c.s. Hemostase en thrombose. Utrecht. Bunge. 1979.

OWEN, C.A. jr., BOWIE, E.J.W., THOMPSON, J.H. jr. The diagnosis of Bleeding Disorders. 2e ed. 1974.

OWREN, P.A. The coagulation of blood. Investigations of a new clotting factor. Acta med.scand., Suppl. 194. 1947. pp 1-327.

*PAVLOVSKY, A. Contribution to the pathogenesis... Blood 2, 1947. pp 185-191.

*PEKELHARING, C.A. Over den aard van het fibrineferment. Onderz.v.h. Phys.Lab. te Utrecht, 4 e reeks 1. 1891. pp 77-118.

* PEKELHARING, C.A. Ueber die Bedeutung der Kalksalze für die Gerinnung des Blutes. Virchows Festschrift, band I. 1891. pp 435-456.

*PEKELHARING, C.A. Over ae samenstelling v.h. fibrineferment. Verslag K.N.A.W. A'dam 3e reeks 9. 1892. pp 293-297. 
*PEKELHARING, C.A. De betekenis der kalkzouten voor de stolling v.h. bloed. Verslag K.N.A.W. A"darn, 3e reeks 9. 1892. pp 73-78, 395-400.

*PEKELHARING, C.A. Ueber die Gerinnung des Blutes. Deutsche Med. Wochenschrift 18.1892. pp 1133-1136.

*PEKELHARING, C.A. Untersuchungen über das Fibrinferment. Verhandelingen der K.N.A.W. 2 e sectie, deel 1, nr. 3.1892/3.

*PEKELHARING, C.A. Onderzoekingen over het fibrineferment. Onderz. v.h.Phys.Lab. te Utrecht. 4e reeks 1. 1893. pp 1-74.

*PEKELHARING, C.A. Over het neerslaan van eiwitstoffen door natriumsulfaat. Onderz.v.h.Phys.Lab. te Utrecht. 4e reeks 2. 1893. pp 278-282.

*PEKELHARING, C.A. In memoriam Jacob Molenschott. N.T.w.Gen. 1893. pp 741-743.

*PEKELHARING , C.A. Louis Pasteur. De Gids, 4e serie 13 IV. 1895.pp 299-323.

*PEKELHARING, C.A. Ueber die Beziehung des Fibrinferments u.s.w. Centralblatt Physiol. 1895. pp 102-111.

*PEKELHARING, C.A. Over de betrekking v.h. fibrinoferment uit het bloedserum tot de nucleoproteide, enz. Onderz.v.h.Phys.Lab. te Utrecht, 4e reeks 4, 1896. pp 1-17. Idem Centralblatt Physiol., 19-4-1895.

*PEKELHARING, C.A. en ZWAARDEMAKER, H. Ibid.2. Onderzoekingen. 1897-1918.

*PEKELHARING, C.A. In memoriam Rudolph Virchow. N.T.v.Gen. 2e deel. 1902. pp 525-528.

*PEKELHARING, C.A. en HUISKAMP, W. Die Natur des Fibrinferments. Zeits.Physiol.Chemie, 39. 1903. pp 22-30.

*PEKELHARING, C.A. en HUISKAMP, W. Over den aard van het fibrineferment. Onderz.v.h.Phys.Lab. te Utrecht. Se reeks 4. 1903. pp 451461.

*PEKELHARING, C.A. De physsiologie in Nederland in de laatste halve eeuw. N.T.v.Gen. 51 i, 1907.pp 9-19. 
*PEKELHARING, C.A. Een paar opmerkingen over fibrineferment. Onderz.v.h.phys.Lab. te Utrecht. Se reeks 9. 1908. pp 1-14.

*PEKELHARING, C.A. Ein paar Bemerkungen über Fibrinferment. Biochem.Z. 11, 1908. pp 1-11.

*PEKELHARING, C.A. Das Aktivieren von Blutserum. Zeits.Physiol. Chemie. 85. 1913. pp 341-345.

*PEKELHARING, C.A. Ueber den Einfluss von Phosphatiden auf die Blutgerinnung. Hoppe-Seyler's Zeits.Physiol.Chemie, 89. 1914. pp 22-38.

*PEKELHARING, C.A. Het "aktiveren" van bloedserum. Onderz.i.h.Phys. Lab. te Utrecht. Se reeks 14. 1914. pp 118-123.

*PEKELHARING, C.A. Over den invloed van phosphatiden op de stolling van het bloed. Onderz.v.h.Phys.Lab. te Utrecht. Se reeks 15. 1915.pp 246-266.

*PEKELHARING, C.A. In memoriam Iwan Petrowitch Pavlov. N.T.v.Gen. $60 \mathrm{I}, 1916 . \mathrm{pp} \mathrm{813-815.}$

*PETIT, J.E. Dissertation sur la manière d'arrester le aang dans les hémorrhagies. Mémoires Acad.Roy.Sci. Paris II, 1731.pp 85-103.

*PETIT, J.E. Sur la manière d'arrester les hémorrhagies. Histoire de l' Acad.Roy.Sci. 1738. pp 14-16.

*QUICK, A.J. The effect of exercise on the excretion of uric acid. 1935. pp 107-112.

QUICK, A.J. On the constitution of prothrombin. Am.J.Physiol. 140. 1943.p. 212.

QUICK, A.J. On the quantitative relationship between calcium and prothrombin. Am.J.Physiol. 148. 1947.p. 211.

*QUICK, A.J. Hemostasis as an evolutionary development. Thromb.Diath. Haemorrh. 18, 1.1967. pp 1-11.

RASPAIL, M. Nouveau système de chimie organique. Paris, 1829.

* RICHARDSON, B.W. The cause of tho coagulation of blood. Churchill, London. 1858. 
RINGER and SAINSBURRY. Journ. of Physiol. Vol. XI. 1890. pp 206 e.v.

*ROLLETT. Physiologie des Blutes und der Blutbewegung. Handbuch der Physiologie. Band IV.

*SABBATINI, S. Azione del citrato trisodico ed importanze del calcioione nella congulazione del sanque. Abstract in Duits. Centralblatt für Physiol. 16. 1902.pp 665-667.

*SABBATANI, S. Function biologique du calcium. La calcium dans la coagulation du sang. Arch.Ital.Biol.39. 1903. pp 333-375.

SALMON, J. VERSTRAETE, M. et BOUNAMEAUX, Y. Fibrinogène plaquettaire et afibrinogénésie. Arch.Int.Physiol. Jrg. 65, 1975. pp $632-634$.

*SAMANA, M. Exploration biologique de l'hemostase et de la coagulation. Examen du Sangulo, 1970. pp 1-12.

*SCHIMMELBUSCH, C. Die Blutplättchen und die Gerinnung. Virchow"s Arch.Path.Anat. 101. 1885. pp 201-244.

*SCHMIDT, A. Ueber den Faserstoff und die Ursachen seiner Gerinnung. Arch.Anat.und Phys. Jrg. 28. 1861.pp 545-587.

*SCHMIDT, A. Ueber den Faserstoff und die Ursachen seiner Gerinnung. Arch.Anat.und Phys. 1861. pp 675-723.

SCHMIDT, A. Weiteres über den Faserstoff und die Ursachen seiner Gerinnung. Arch.Anat.und Phys. Jrg. 29. 1862.

SCHMIDT, A. Kleine physiologisch-chemische Untersuchungen. Virchow's Arch.Path.Anat. Bd. 29. 1864.

SCHMIDT, A. Haematologische Studiën. Dorpat, 1865.

*SCHMIDT, A. Neue Untersuchungen über die Faserstoffgerinnung. Arch. f.d.ges.Physiol.d.Menschen u.d.Tiere. Bd. 6, 1872. pp 413-538.

SCHMIDT, A. Ueber die Beziehungen des Faserstoffes zu den farblosen und roten Blutkörperchen und über die Entstehung der letzteren Vorläufige Mitteilungen. Pflüger's Archiv ges.Physiol. Bd. 9, 1874. 
SCHMIDT, A. Ueber die Beziehung der Faserstoffgerinnung zu den Körperlichen Elementen des Blutes. Pflüger's Archiv ges.Physiol. 11,1875. pp 515 e.v.

*SCHMIDT, A. Die Lehre von den fermentatieven Gerinnungsercheinungen in den eiweissartigen thierischen Körperflüssigkeiten. Dorpat Verlag C. Mattiesen. 1876.pp 1-62.

SCHMIDT, A. Bemerkungen zu Hammarsten's Abhandlung: Untersuchungen über die Faserstoffgerinnung. Nova Acta Reg. Soc.v.Scient. Upsaliensis 1875. Pflüger's Archiv ges.Physiol. Bd. 13. 1876.

*SCHMIDT, A. Ueber den Faserstoff und die Ursachen der Gerinnung. Arch.Anat.und Phys. 1891.pp 545-587.

*SCHMIDT, A. Zur Blutlehre. F.C.W. Vogel Verlag, Leipzig. 1892.

*SCHMIDT, A. Weitere Beiträge zur Blutlehre. Bergmann Wiesbaden. 1895.

* SCHROEDER VAN DER KOLK, J.L.C. Dissertatio physiologico-medica. Historia coagulationis sanguinis. Groningen, 1820. pp 1-91.

SEEGERS, W.H. Prothrombin. Cambridge Mass. Harvard Univ. Press 1962. pp 111-113, 145-185, 285-319, 382-443.

SEEGERS, W.H. Prothrombin in Enzymology, Thrombosis and Hemophilia. Springfield, C.T. Thomas Publ. 1967.

SEEGERS, W.H. Blood Clotting Enzymology. New York Acad. Press 1967. pp 1-21.

*SEEGERS, W.H. Half a Century before Prothrombin. App. 1962. pp 616632 .

*SCHROER, H. Die Entwicklung der Hämostaseologie. Uit: Einführung in die Geschichte der Hämatologie. 1974. pp 80-98.

*SPIRO, K., ELLINGER, A. Der Antagonismus gerinnungsbefördernder und gerinnungshemmender Stoffe im Blute und die sogenannte PeptonImmunität. Uit: Phys.-Chem.Inst. in Strassburg Neue Folge nr. 1. 1897. 
* SCHWALBE, E. Untersuchungen zur Blutgerinnung. Braunschweig Verlag Viehweg u. Sohn. 1900.pp 1.89.

*STODDART, A.M. The life of Paracelsus (1493-1545?). London, John Murray. 1911.pp 211-213.

SUTTIE, J.W. Cellular biochemistry of prothrombin synthesis. Wayne State Univ. School of Medicine. Symp. Detroit 18-19 Jun. 1973. p. 6.

THACKRAH, C.T. An inquiry into the nature and properties of the blood, as existent in health and disease. New England J.Med.9.1820.

*TOCANTHIUS, L.M. Platelets and the spontaneous syneresis of blood clots. Am.J.Physiol. Jrg. 110. 1934. pp 278-286.

*TOCANTHIUS, M.L. Platelets a. the structure and physical properties of blood clots. Am.J Physiol. Jrg. 114. 1936. pp 709-715.

*TOCANTIUS, L.M. Uit: The coag. of blood, methods of study. Chapter II, Introductory exercises. 1955.

*VERSO, M.L. The contributions of Andrew Buchanan on the study of blood coagulation. Med.J.Australia 9-4-1960. pp 576 e.w.

*VERSO, M.L. Some notes on a contemporary review of early French haematology. Med.Hist. 1961. pp 239-252.

*VERSO, M.L. The evolution of the blood counting techniques. 1964.

*VERSO, M.L. Some nineteenth-cent. pioneers of haematology . Read at a meeting in Melbourne of the section of Med.Hist. 1969.

VIERORDT, C.H. Die Gerinnungszeit des Blutes u.s.w. Arch. Heilkunde 19. 1878. p. 193.

*VIRCHOW, R. Zur pathologischen Physiologie des Blutes. Arch.f.path. Anat.u.Phys.u.f.Klin.Med. R. Virchow und B. Reinhardt Eds. G. Reimer Verlag. 1847. pp 547-583.

*VIRCHOW, R. Uit: Mannen van betekenis. R.U. Utrecht. 1854.

VIRCHOW, R. Thrombose und Embolie. Ges. Abhand. z.Wiss.Med. von Rudolph Virchow. Frankfurt, Von Meidinger, 1856. pp $219-732$. 
VIRCHOW, R. Ueber den Faserstoff. Ges.Abhand.2.Wiss.Med.Grothe, Hannover 1862. pp 59-145.

*VIRCHOW, R. Ueber Erziehung d. Aerzte. Congres Amsterdam, K.N.A.W. Sept. 1879.

*VIRCHOW, R. Een leven in brieven 1839-1864.

*VROMAN, L. Texchrome silhouette. Staining of platelets. 1949.

*VONK. De oorzaken van de bloedstolling. Vakbl. v. Biol. 1966. pp 87-95.

*WAGNER, R. Handwörterbuch der Physiologie. Braunschweig , 1842. pp 75-165.

WARNER, E.D., BRINKHOUS, K.M., SMITH, HP. The prothrombin conversion rate in various species. Proc.Soc.Exp.Biol.Med. 1939/40. p.197.

*WOLISCH, E. Die Physiologie und Pathologie der Blutgerinnung. Erg.d. Physiol. Bd. 28. 1929. pp 443-624.

*WOELISCH, E. Fortschritte in der Physiologie der Blutgerinnung. Ergebnisse der Physiol. 43. 1940. pp 174-371.

*WOELISCH, E. Die Blutgerinnung: Forscher und Faktoren. Schweiz. Med.Wochenschr. 29. 1954. pp 774-776.

*WOOLDRIDGE, L.C. Die Gerinnung des Blutes. Leipzig, Verlag von Veit. u.Comp. 1891.

WOOLDRIDGE, L.C. Ueber intravasculäre Gerinnungen. Arch.Anat.und Phys. 1886, p. 397.

WRIGHT, J.H. The origin and nature of the blood plates. Boston Med. and Surgical Journ. Jrg. 54. pp 643-645.

*WRIGHT, J.H. e.a. The viscous metamorphosis of the blood platelets. Journ. of Exp.Medicine. Jrg. 26. 1917. pp 395-409.

*ZIEGLER, E. Neue Arbeiten über Blutgerinnung. Centralblatt f.allg.Path. und path.Anat. Bd. IV. 1893. pp 970-980. 


\section{Summary and conclusion}

In this thesis an attempt is made to describe the development of the prothrombine concept during the 19 th century.

First a short review is given of the state of knowledge around the beginning of that century. There is no doubt that then as well as later confusion is the major characteristic of the situation in this field. The phenomenon of blood coagulation presents itself as a matter of course to all inversigators but hardly anybody before or around $1830 \mathrm{can}$ produce experiments that sort out plausible and implausible explanations. Physical, chemical and vitalistic theories are conjectured from ancient times until the middle of the last century and a common opinion is not to be found.

In this thesis this situation is describied only in so far as it is necessary to understand later developments.

For investigators willing to do further research in this part of the history of science, the thesis of Schröder van der Kolk (1820) is reproduced in facsimile. It treats the subject of blood coagulation as it was known in that time in a historical perspective and contains as far as I could judge all relevant older literature.

One of the main conclusions of a first survey of 19th century literature must be that it is often impossible to judge whether in old experiments thrombin or tissue thromboplastin is the clot promoting agent. The main controversy of the last century is that between those who thought fibrin to arise from a stoichiometric interaction between two plasma constituents, a point of view of which Alexander Schmidt was the main proponent and those who visualised fibrin formation as being caused by the action of an enzyme on a plasma protein. (Buchanan, Hammersten, Pekelharing). That this controversy could not be easily settled is explained by the fact that on the one hand the clotting of a mixture of serum or any other fibrinogen-free plasma preparation will be enhanced by a number of types of thromboplastin-rich preparations, including blood cells, whereas on the other hand fibrinogen con- 
taining preparations are clotted by thrombin containing preparations. The first situation suggests a stoichiometric interaction catalysed by a third component, the second one of course leads to the correct conclusion.

In order to try and sort out the literature I decided to repeat the old experiments exactly as described by the original authors.

With the experiments of some authors like Buchanan and Pekelharing this could readily be done. The experiments of Schmidt on the other hand defy this approach because they, however meticulously described, are unclear at precisely those points that we now recognise to be essential. This illustrates an interesting point in the nature of scientific discovery. Apparently Schmidt was not able to seperate those experimental variables that nowadays are recognised to be significant from those that are not. But in order to recognise significant variables one has to know the outcome of significant experiments. To escape from this loop is the hailmark of the successful investigator, as has been well recognised by the investigators themselves. As it may be seen from the well known words of Pasteur: "Chance only favours the prepared mind". The fact that I have not been able to repeat experiments described by Schmidt in an unequivocal way thus in itself is significant for the understanding of the historical development.

The experiments of Buchanan are readily repeatable and they demonstrate clearly that clotting can be brought about by addition of catalytic amounts of thrombin to a fibrinogen solution. This is also the conclusion Buchanan drew. From the repetition of his experiments it is clear however that Buchanan must have observed thromboplastin effects almost as frequently as thrombin effects. This raises the interesting question of whether a discovery made by an investigator on dubious grounds should indeed be attributed to him. I feel no sensible answer can be given to this question and would tend to adopt the modern view that correctness of an interpretation is less important for science that its liability to falsification. The experiments of Buchanan can be repeated and his conclusions 
might have been falsified. The experiments of Schmidt do not allow repetition and hence his conclusions can not be considered scientific statements in the modern sense of the word.

This should in no way suggest however that a modern reader does not aquire a great esteem for the scientific personality of Alexander Schmidt. Indeed his occupation with the problem of blood coagulation has catalysed research in this field for the latter half of the 19 th century. Also the fact that he was recognised in his time as an expert in the field made that much of the scientific communication went through his works and the discussion thereof by others, in this way canalising the stream of information that in those times - as compared to later standards - was very diffuse indeed.

In the last quarter of the last century it becomes increasingly clear, primarily through the work of Hammersten and Pekelharing, that Buchanans concept of coagulation as an enzymatic reaction on one substrate, mediated by thrombin, is the right one.

In a series of experiments designed to prove the existance and provenance of thrombin Pekelharing then suddenly finds that it is possible to prepare a fraction from human plasma that in itself will not cause fibrinogen to clot but that, after suitable activation, will have this action. He draws the correct conclusion that thrombin exists in plasma in a precursor form. One may therefore ascribe the discovery of prothrombin to Pekelharing, or rather would one say: If this discovery is to be ascribed to anybody it is to Pekelharing that we have to grant it. At the same time it should be recognised that Schmidt already had postulated prothrombin but without a firm experimental basis. Also it must be mentioned that prothrombin in the mind of Pekelharing is not to be confused with the well defined protein we think of now if we use this word. Indeed Pekelharing believed that thrombin could arise from a large variety of phosphorus-containing proteins occuring in blood cells and many tissues. His further description of prothrombin applies best to........thromboplastin! Once again confusion reigns, be it half a step further up the clotting cascade. It will 
last until 1964 before the concept of prothrombin in anything like its modern form is accepted by the majority of investigators.

If one studies the early attempts to gain understanding in this obviously difficult field the primary feeling that remains is one of admiration for all investigators involved, be it only for their courage to begin such a seemingly hopeless task. 
Samenvatting en conclusies.

In dit proefschrift heb ik gepoogd de ontwikkeling van het begrip prothrombine gedurende de $19 \mathrm{e}$ eeuw te schetsen. Eerst wordt er een kort overzicht gegeven van de kennis op het gebied van de bloedstolling omstreeks het begin van die eeuw. Er is geen twijfel an dat dit gebied in die tijd zo goed als later voornamelijk wordt gekenmerkt door verwarring. Als welhaast vanzelfsprekend verschijnsel kent iedere natuuronderzoeker het stollen van bloed maar bijna niemand kan tot omstreeks 1830 experimenten laten zien die een keuze mogelijk maken tussen waarschijnlijke en onwaarschijnlijke verklaringen. Natuurkundige, chemische en vitalistische theorieën worden vanaf de oudheid reeds geponeerd maar tot een communis opninio komt het niet. In dit proefschrift wordt de vroege situatie slechts in zoverre beschreven als dat nodig is om latere ontwikkelingen te begrijpen. Voor onderzoekers die dieper willen ingaan op de vroege geschiedenis van de gedachten over de bloedstolling heb ik het proefschrift van Schroeder van der Kolk (1820) in facsimile gereproduceerd. Het behandelt de status quo van de kennis van de bloedstolling op dat moment en geeft een uitgebried overzicht van de oude literatuur.

Een van de belangrijkste conclusies van een eerste speurtocht op het gebied van de bloedstolling moet zijn dat het vaak onmogelijk is om te beoordelen of in een oud experiment thrombine of thromboplastine het stollingsverwekkende agens is geweest. De belangrijkste controverse van de vorige eeuw is, op het gebied van de stolling, die tussen degenen die dachten dat fibrine ontstaat uit de stoiciometrische interactie van twee plasmabestanddelen, een standpunt waarvan Alexander Schmidt de belangrijkste voorstander was, en degenen die de fibrinevorming zagen als veroorzaakt door de werking van een enzym op een plasmaeiwit (Buchanan, Hammersten, Pekelharing). Dat deze controverse niet gemakkelijk beslecht kon worden werd veroorzaakt door het feit dat enerzijds de stolling van een mengsel van serum of enig ander fibrinogeenvrij plasmapreparaat samen met een fibrinogeenrijk preparaat bevorderd zal worden 
door een groot aantal thromboplastinerijke preparaten, waaonder beschadigde bloedcellen, terwijl anderzijds fibrinogeen bevattende preparaten stollen o.i.v. thrombinebevattende mengsels. Het eerste geval suggereert een stoichiometrische interactie bevorderd door een derde preparaat, terwijl het tweede tot de correcte conclusie leidt.

In een poging om op dit punt helderheid te krijgen over de bedoelingen en waarnemingen van de oorspronkelijke auteurs besloot ik een aantal van hun proeven zo precies mogelijk te herhalen. Met de experimenten van sommige auteurs zoals Buchanan en Pekelharing leverde dit geen problemen op. De experimenten van Schmidt daarentegen weerstaan deze poging tot toenadering omdat $\mathrm{zij}$, hoe nauwkeurig zij ook zijn beschreven, onduidelijk zijn op juist die punten die we tegenwoordig als essentieel zien. Dit illustreert een interessant vraagpunt over het wezen van de wetenschappelijke ontdekking. Klaarblijkelijk was Schmidt niet in staat die experimentele variabelen waarvan wij nu weten dat $\mathrm{zij}$ van doorslaggevende betekenis zijn, te scheiden van die die wij heden onbelangrijk weten te zijn. Maar om te weten wat de significante variabelen zijn moet men de uitslag van als significant herkende proeven kennen. In staat te zijn uit deze cirkelgang los te breken is wat een onderzoeker tot een succesvol onderzoeker maakt. Dit wordt trouwens door henzelf het eerst erkend; zegt niet Pasteur dat het toeval alleen de voorbereide geest te hulp schiet.

Het feit dat ik niet in staat ben geweest de experimenten van Schmidt te herhalen zodanig dat binnen de door hem aangegeven marges ondubbelzinnige experimenten zouden worden uitgevoerd, is op zichzelf reeds significant voor het begrip van de historische ontwikkeling.

De experimenten van Buchanan kunnen eenvoudig herhaald worden en zij laten duidelijk zien dat stolling kan worden teweeggebracht door de toevoeging van kataly tische hoeveelheden thrombine aan een fibrineoplossing. Dat is ook de conclusie die Buchanan heeft getrokken. Uit de herhaling van zijn experimenten wordt echter duidelijk dat Buchanan in zijn proefopzet ook thromboplastine-effecten moet hebben gezien, en wel 
bijna net zo vaak als thrombine-effecten. Dit werpt de interessante vraag op of men een ontdekking, die door een onderzoeker op twijfelachtige basis wordt gedaan, eigenlijk wel aan hem moet toekennen. Naar mijn gevoel is op deze vraag geen zinvol antwoord te geven. Ik zou er eerder toe neigen het moderne standpunt in te nemen dat een al of niet correcte uitspraak minder belangrijk is dan het feit of die uitspraak voor zinvolle toetsing en tegenspraak toegankelijk is. De experimenten van Buchanan zijn herhaalbaar en zijn conclusies zouden in principe gefalcificeerd kunnen worden.

De experimenten van Schmidt staan niet of nauwelijks zinvolle herhaling toe en daarom kunnen zijn conclusies in de moderne zin van het woord niet meer als wetenschappelijke stellingen juist of onjuist - worden opgevat. Dit suggerere echter geenszins dat een moderne lezer niet bij het doornemen van de werken van Alexander Schmidt voor deze wetenschapsbeoefenaar de grootste achting voelt opkomen. Zijn niet aflatende ijver en sterke persoonlijkheid zijn de belangrijkste katalysatoren geweest voor het bloedstollingsonderzoek in de tweede helft van de $19 \mathrm{e}$ eeuw. Ook heeft het feit dat hij in zijn tijd als de grootste expert op dit gebied werd gezien er toe bijgedragen dat de wetenschappelijke communicatie daarover door en via zijn werken geschiedde. Op die manier kon in zijn tijd iedere in de stolling geinteresseerde onderzoeker van de meest belangrijke recente feiten op de hoogte zijn, iets dat in de eerste helft van de vorige eeuw zo goed als onmogelijk was.

In het laatste kwart van de vorige eeuw wordt het steeds duidelijker, vooral door het werk van Hammersten en Pekelharing, dat Buchanans concept: de stolling als een enzymatisch gebeuren, het juiste was. In een serie experimenten die ten doel hadden het bestaan en de herkomst van thrombine te bewijzen, vindt Pekelharing dan plotseling dat het mogelijk is om uit plasma een fractie te bereiden die zelf geen fibrinogeen bevat en ook fibrinogeen niet doet stollen, maar die na activering fibrinogeen wel degelijk omzet in fibrine. Hij trok de correcte conclusie dat er een voorloper van thrombine in plasma voorkomt. Hierdoor kunnen we de ontdekking van het prothrombi- 
ne aan Pekelharing toeschrijven. Liever nog zou ik zeggen: Als die ontdekking aan lemand moet worden toegeschreven, dan aan Pekelharing. Tezelfdertijd moet echter worden ingezien dat Schmidt reeds een prothrombine gepostuleerd had, zij het zonder enige experimentele basis. Ook moet vermeld worden dat Pekelharings prothrombine niet verward moet worden met het goed gedefinieerde eiwit dat we nu kennen. Pekelharing geloofde dat prothrombine kon ontstaan uit een grote verscheidenheid van phosphorbevattende eiwitten die in bloedcellen en vele andere weefsels voorkwamen.

Zijn beschrijving van prothrombine past nog het beste op wat wij heden ten dage kennen als......thromboplastine. Weer maakt zich verwarring meester van het terrein, zei het een halve stap hoger in de stollingscascade. Het zal nog tot 1964 duren voordat het begrip prothrombine in iets dat lijkt op onze huidige opvatting, het merendeel van de onderzoekers voor ogen staat. Als men een studie maakt van de vroege pogingen om inzicht te verkrijgen in dit kennelijk zo moeilijke gebied is het belangrijkste dat daarvan overblijft een gevoel van bewondering voor alle betrokken onderzoekers. Al was het alleen maar voor de moed waarmee zij aan zo'n ogenschijnlijk hopeloze taak begonnen. 


\section{Curriculum vitae}

De schrijver van dit proefschrift werd geboren te Amsterdam op 29 juni 1911. Na het doorlopen van de Ambachtsschool, de Electrotechnische School en de Middelbaar Technische School (thans H.T.S.) trad hij in 1933 als technicus in dienst bij de P.T.T. Tot 1939 was hij werkzaam te Amsterdam, daarna tot 1946 in 's Gravenhage. In deze periode werden enkele cursussen gevolgd, zoals bouwkunde en Makelaardij, beëdigd als makelaar in onroerend goed 1937.

Van 1947 tot 1960 werkte hij als instrumentmaker en hoofd van de electrotechnische afdeling bij het Fysiologisch Laboratorium der Gemeente Universiteit van Amsterdam onder Prof. Dr. J. ten Cate.

Hier werd onder andere, in samenwerking met het Natuurkundig Laboratorium, onder zijn leiding een vierkanaals encefalograaf geconstrueerd met een versterkingsfactor $5.10^{6}$. een technische prestatie waarvoor destijds een speciale onderscheiding van de Gemeente Amsterdam werd verkregen. Van 1957 tot 1962 volgde de auteur een studie voor de akte M.O. Biologie aan de Universiteit van Amsterdam. Vanaf 1960 werd de avondstudie omgezet in een volledige dagstudie.

In $196 \mathrm{r}$ startte hij met een gedeeltijke dagtaak een loopbaan als leraar biologie bij het Middelbaar Onderwijs. Vanaf 1962 tot 1974 was hij werkzaam als leraar aan het Spinoza Lyceum te Amsterdam. Na zijn pensionering begon de schrijver zijn studie op het gebied van de bloedstolling aan de Rijksuniversiteit Limburg te Maastricht. In 1978 deed hij doctoraalexamen biologie aan de Vrije Universiteit te Amsterdam en vanaf die tijd wijdde hij een belangrijk gedeelte van zijn tijd aan het schrijven van dit proefschrift. 